Prepared in cooperation with the Metro Wastewater Reclamation District

\title{
Effects of Surface Applications of Biosolids on Groundwater Quality and Trace-Element Concentrations in Crops near Deer Trail, Colorado, 2004-2010
}

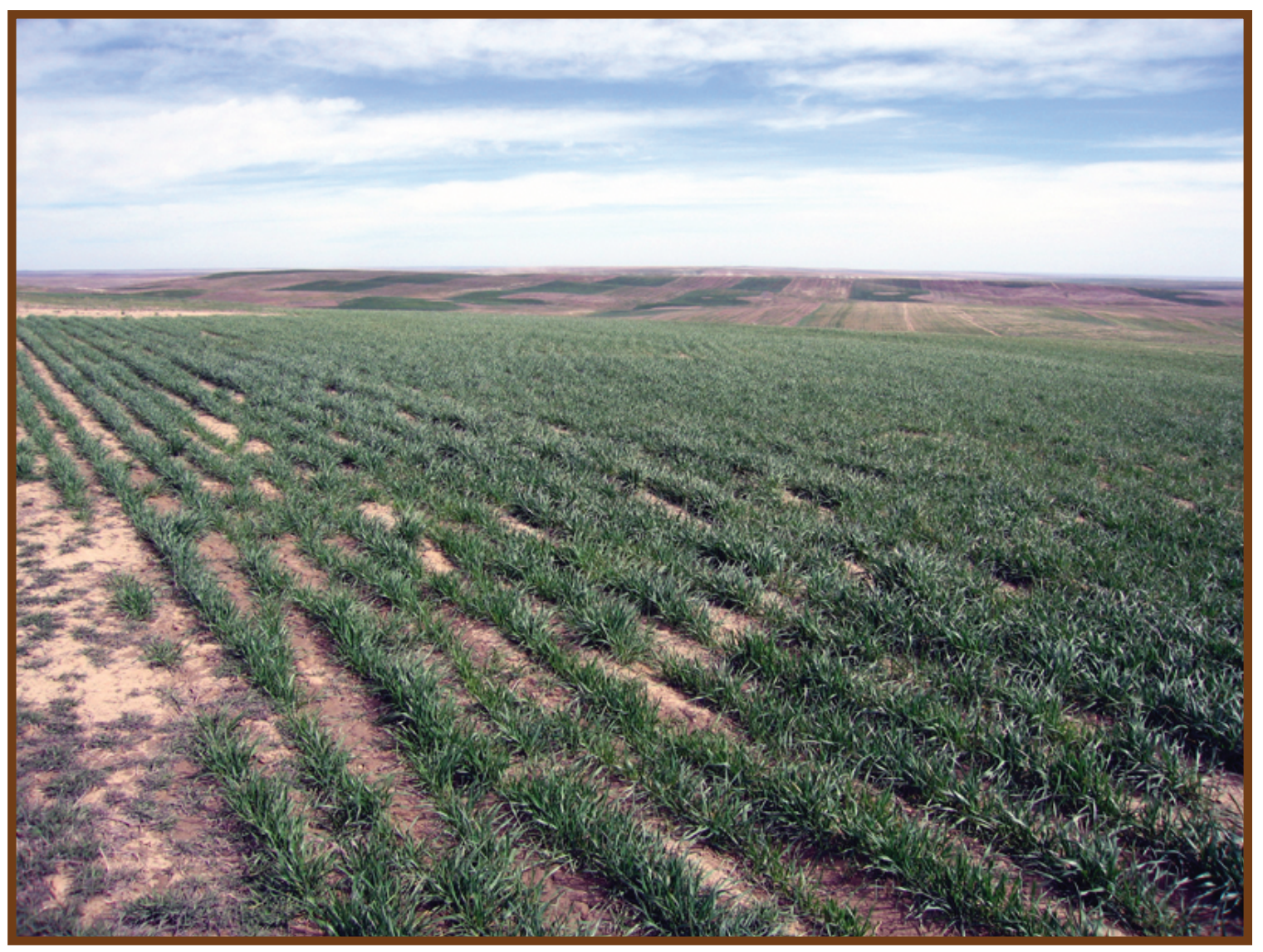

Scientific Investigations Report 2013-5065 
COVER. Farmland near U.S. Geological Survey monitoring well D29. 


\section{Effects of Surface Applications of Biosolids on Groundwater Quality and Trace-Element Concentrations in Crops near Deer Trail, Colorado, 2004-2010}

By Tracy J.B. Yager, James G. Crock, David B. Smith, Edward T. Furlong, Philip L. Hageman, William T. Foreman, James L. Gray, and Rhiannon C. ReVello

Prepared in cooperation with the Metro Wastewater Reclamation District

Scientific Investigations Report 2013-5065 


\title{
U.S. Department of the Interior SALLY JEWELL, Secretary
}

\section{U.S. Geological Survey Suzette M. Kimball, Acting Director}

\author{
U.S. Geological Survey, Reston, Virginia: 2013
}

For more information on the USGS - the Federal source for science about the Earth, its natural and living resources, natural hazards, and the environment, visit http://www.usgs.gov or call 1-888-ASK-USGS.

For an overview of USGS information products, including maps, imagery, and publications, visit http://www.usgs.gov/pubprod

To order this and other USGS information products, visit http://store.usgs.gov

Any use of trade, firm, or product names is for descriptive purposes only and does not imply endorsement by the U.S. Government.

Although this information product, for the most part, is in the public domain, it also may contain copyrighted materials as noted in the text. Permission to reproduce copyrighted items must be secured from the copyright owner.

Suggested citation:

Yager, T.J.B., Crock, J.G., Smith, D.B., Furlong, E.T., Hageman, P.L., Foreman, W.T., Gray, J.L., and ReVello, R.C., 2013, Effects of surface applications of biosolids on groundwater quality and trace-element concentrations in crops near Deer Trail, Colorado, 2004-2010: U.S. Geological Survey Scientific Investigations Report 2013-5065, 119 p., http://pubs.usgs.gov/sir/2013/5065/. 


\section{Contents}

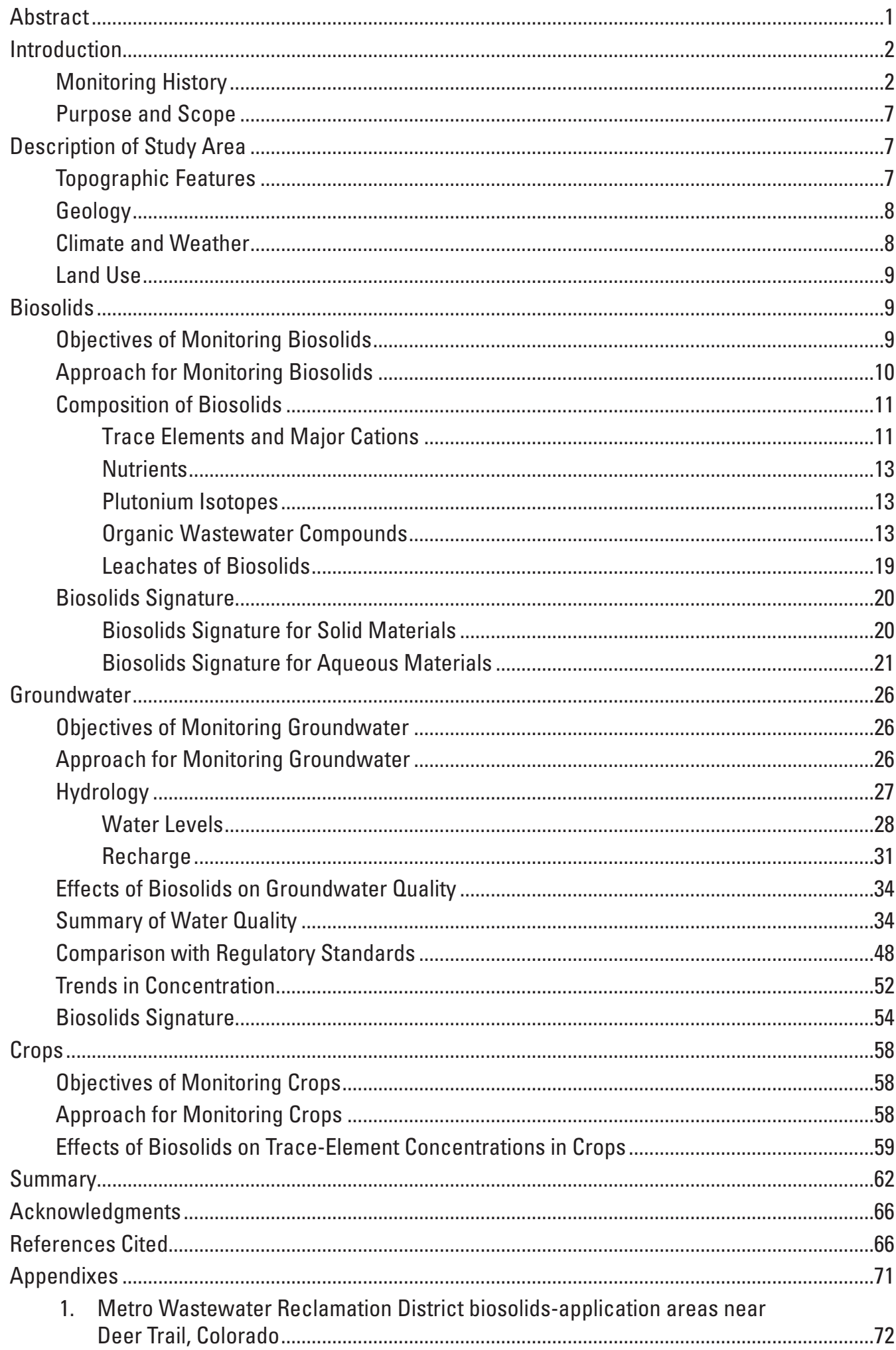


2. Comparison of organic wastewater compound data for biosolids and replicate samples collected from the Metro Wastewater Reclamation District and analyzed by the U.S. Geological Survey National Water Quality Laboratory, December 2006.

3. Surrogate and matrix-spike recoveries for fresh biosolids samples collected from the Metro Wastewater Reclamation District and analyzed for organic wastewater compounds by the U.S. Geological Survey National Water Quality Laboratory, 2006

4. Analytical data for leachate and groundwater samples associated with the biosolids-application area near Deer Trail, Colorado, 2005.

5. Matrix-spike recoveries for leachate and groundwater samples associated with the Metro Wastewater Reclamation District biosolids-application area near Deer Trail, Colorado, 2005, and analyzed by the U.S. Geological Survey National Water Quality Laboratory.

6. Selected information for U.S. Geological Survey monitoring wells near Deer Trail, Colorado, 2004-2010

7. Relative standard deviation for replicate groundwater samples collected near Deer Trail, Colorado, 2004-2010.

8. Absolute difference for replicate groundwater samples collected near Deer Trail, Colorado, 2004-2010.

9. Percent difference for replicate groundwater samples collected near Deer Trail, Colorado, 2004-2010...

10. Statistical comparison of concentrations for selected dissolved constituents in groundwater samples collected near Deer Trail, Colorado, 2004-2010, and water-quality standards..

11. Statistical evaluation of time-series trend using the Kendall's tau correlation coefficient for selected dissolved constituents in groundwater samples collected near Deer Trail, Colorado, 2004-2010

\section{Figures}

1. Map showing location of study area near Deer Trail, Colorado.

2. Map showing location of U.S. Geological Survey monitoring sites near Deer Trail, Colorado, 2004-2010

3. Photographs showing biosolids applied by Metro Wastewater Reclamation District at the agronomic loading rate in eastern Colorado in 2007 at $A$, application day; and $B, 20$ days post-application (photographs from U.S. Geological Survey)

4. Graphs showing concentrations of regulated elements in biosolids sampled monthly from the Metro Wastewater Reclamation District during 2004 through 2010 compared to Colorado standards for biosolids (Colorado Department of Public Health and Environment, 2003)

5. Graphs showing monthly water-level data for selected U.S. Geological Survey monitoring wells near Deer Trail, Colorado, 2004-2010

6. Graphs showing continuous water-level altitudes for wells DTX9, DTX10, and DTX11, and precipitation data for the recharge-evaluation area near Deer Trail, Colorado, 2004-2010

7. Boxplots summarizing groundwater quality for selected dissolved constituents from all samples collected near Deer Trail, Colorado, 2004-2010. 
8. Boxplots summarizing groundwater quality for selected constituents for selected wells near Deer Trail, Colorado, 2004-2010.

9. Graphs showing groundwater concentrations near Deer Trail, Colorado, for selected dissolved constituents and selected wells, 2004-2010. (Dotted vertical lines represent data that were reported by the laboratory as less than the reporting level.)

10. Map showing Arapahoe County, Colorado, crop-sampling area ......................................5

11. Map showing Elbert County, Colorado, crop-sampling area..........................................60

12. Boxplots summarizing concentrations of selected constituents in wheat grain for all untreated-field samples compared to all treated-field samples collected near Deer Trail, Colorado, 2004-2010

\section{Tables}

1. Comparison of organic wastewater compound data for two fresh biosolids samples collected from the Metro Wastewater Reclamation District and analyzed by the U.S. Geological Survey National Water Quality Laboratory, 2006

2. Preliminary biosolids signature to indicate presence of biosolids in study-area soil and sediment

3. Preliminary biosolids signature to indicate the presence of biosolids in groundwater or surface water in the study area

4. Preliminary cow-manure signature to indicate the presence of cow manure in groundwater or surface water.

5. Summary of all groundwater-quality data collected near Deer Trail, Colorado, during 2004-2010, and groundwater regulatory limits.

6. Variability estimates for groundwater-quality data computed from comparisons of water-quality data for groundwater and replicate samples collected near Deer Trail, Colorado, 2004-2010.

7. Summary of results for statistical evaluation of groundwater-quality data for selected constituents in samples from selected wells near Deer Trail, Colorado, 2004-2010

8. Summary of biosolids-signature information for groundwater samples collected from selected monitoring wells near Deer Trail, Colorado, 2004-2010

9. Indications of biosolids effects on groundwater from samples collected from selected monitoring wells near Deer Trail, Colorado, 2004-2010

10. Comparison of concentration of priority parameters in wheat grain from monitoring fields near Deer Trail, Colorado (this study), 2004-2010, with those from other published studies 


\section{Conversion Factors and Datums}

\begin{tabular}{|c|c|c|}
\hline Multiply & By & To obtain \\
\hline \multicolumn{3}{|c|}{ Length } \\
\hline inch & 2.54 & centimeter $(\mathrm{cm})$ \\
\hline inch & 25.4 & millimeter (mm) \\
\hline foot $(\mathrm{ft})$ & 0.3048 & meter $(\mathrm{m})$ \\
\hline mile (mi) & 1.609 & kilometer (km) \\
\hline centimeter $(\mathrm{cm})$ & 0.3937 & inch \\
\hline \multicolumn{3}{|c|}{ Area } \\
\hline section (640 acres or 1 square mile) & 259.0 & square hectometer $\left(\mathrm{hm}^{2}\right)$ \\
\hline square mile $\left(\mathrm{mi}^{2}\right)$ & 259.0 & hectare (ha) \\
\hline square mile $\left(\mathrm{mi}^{2}\right)$ & 2.590 & square kilometer $\left(\mathrm{km}^{2}\right)$ \\
\hline \multicolumn{3}{|c|}{ Volume } \\
\hline liter $(\mathrm{L})$ & 0.2642 & gallon (gal) \\
\hline \multicolumn{3}{|c|}{ Flow rate } \\
\hline acre-foot per year (acre-ft/yr) & 1,233 & cubic meter per year $\left(\mathrm{m}^{3} / \mathrm{yr}\right)$ \\
\hline foot per year $(\mathrm{ft} / \mathrm{yr})$ & 0.3048 & meter per year $(\mathrm{m} / \mathrm{yr})$ \\
\hline \multicolumn{3}{|c|}{ Mass } \\
\hline gram $(\mathrm{g})$ & 0.03527 & ounce, avoirdupois (oz) \\
\hline kilogram (kg) & 2.205 & pound avoirdupois (lb) \\
\hline
\end{tabular}

Temperature in degrees Celsius $\left({ }^{\circ} \mathrm{C}\right)$ may be converted to degrees Fahrenheit $\left({ }^{\circ} \mathrm{F}\right)$ as follows:

${ }^{\circ} \mathrm{F}=\left(1.8 \mathrm{x}^{\circ} \mathrm{C}\right)+32$

Vertical coordinate information is referenced to the North American Vertical Datum of 1988 (NAVD 88).

Horizontal coordinate information is referenced to the North American Datum of 1983 (NAD 83).

Altitude, as used in this report, refers to distance above the vertical datum.

Specific conductance is given in microsiemens per centimeter at 25 degrees Celsius $(\mu \mathrm{S} / \mathrm{cm}$ at $\left.25^{\circ} \mathrm{C}\right)$.

Concentrations of chemical constituents in water are given either in milligrams per liter (mg/L), micrograms per liter $(\mu \mathrm{g} / \mathrm{L})$, or milligrams per kilogram $(\mathrm{mg} / \mathrm{kg})$, which is equivalent to parts per million (ppm), or percent (\%). 


\title{
Effects of Surface Applications of Biosolids on Groundwater Quality and Trace-Element Concentrations in Crops near Deer Trail, Colorado, 2004-2010
}

\author{
By Tracy J.B. Yager, James G. Crock, David B. Smith, Edward T. Furlong, Philip L. Hageman, \\ William T. Foreman, James L. Gray, and Rhiannon C. ReVello
}

\section{Abstract}

The U.S. Geological Survey (USGS), in cooperation with Metro Wastewater Reclamation District (Metro District), studied biosolids composition and the effects of biosolids applications on groundwater quality and trace-element concentrations in crops of the Metro District properties near Deer Trail, Colo., during 2004 through 2010. Priority parameters for each monitoring component included the nine trace elements regulated by Colorado for biosolids (arsenic, cadmium, copper, lead, mercury, molybdenum, nickel, selenium, and zinc).

Monthly biosolids samples from the wastewater treatment plant in Denver were analyzed for the priority parameters and other constituents, including (for selected samples) nitrogen, phosphorus, plutonium isotopes, and organic wastewater compounds (OWCs: wastewater indicators, pharmaceuticals, and hormones). All concentrations for the priority parameters in biosolids samples were less than Colorado regulatory limits, and the concentrations were relatively consistent. Biosolids likely were the largest source of nitrogen and phosphorus on the Metro District properties. Plutonium isotopes were not detected in the biosolids, but many OWCs were detected in substantial concentrations relative to minimum reporting levels and various surface-water concentrations. Pharmaceuticals and steroid hormones composed much less of the total OWCs content than wastewater indicators in these samples collected in 2006. Inorganic and organic constituents of biosolids can be mobilized in the presence of water. Some hydrophobic compounds were detected in biosolids leachates, and a field-aged (8 months) biosolids sample leached detectable concentrations of some OWCs despite repeated exposure to precipitation and freeze-thaw cycles in the field. Bismuth, copper, mercury, nitrogen, phosphorus, silver, biogenic sterols, detergent degradates, disinfectants, fire retardants, fragrances, pharmaceuticals, and plasticizers would be the most likely biosolids signature to indicate the presence of Metro District biosolids in soil or streambed sediment from the study area. Antimony, cadmium, cobalt, copper, molybdenum, nickel, nitrogen, phosphorus, selenium, tungsten, vanadium, zinc, detergent degradates, disinfectants, fire retardants, fragrances, pharmaceuticals or their degradates, and plasticizers would be the most likely biosolids signature for groundwater and surface water in the study area. More biosolids-signature components detected and larger concentration differences from untreated materials, baseline, and blank samples indicate more evidence of biosolids presence or effects.

Groundwater in the study area routinely was monitored for hydrology (monthly water-level data plus continuous data) and chemistry (quarterly sampling) at USGS monitoring wells. All groundwater samples were analyzed for the priority parameters, nitrogen forms, and many other constituents. Samples from five routinely sampled alluvial-aquifer wells also were analyzed for dissolved OWCs (wastewater indicators, only) once in 2005. The median concentrations of priority parameters for all groundwater samples were small (near or less than minimum reporting levels). Although the inorganic constituent concentrations were relatively large in samples from one well, the concentrations of OWCs were not correspondingly large. Concentrations of OWCs in the groundwater samples from all five monitoring wells were less than the minimum reporting levels with only a few detections. Some of the OWCs detected could have anthropogenic sources that are not biosolids. Concentrations of priority parameters in groundwater varied spatially and temporally but generally were less than Colorado regulatory limits. Groundwater concentrations of dissolved cadmium, chromium, copper, lead, mercury, nickel, and zinc in all samples met the Colorado standards. All groundwater concentrations of the OWCs that had standards also met the Colorado standards. Concentrations of dissolved nitrate, arsenic, and selenium, in addition to chloride, sulfate, total dissolved solids, boron, iron, manganese, and uranium, in samples from some wells exceeded the Colorado standards. A statistical evaluation of selected water-quality data for selected wells indicates that groundwater concentrations for 2004-2010 were significantly $($ alpha $=0.05)$ higher than the lowest regulatory standard for dissolved nitrate (one well), selenium (one well), and uranium (two wells). Concentrations of dissolved nitrate (three wells), molybdenum (one well), selenium (two wells), and uranium (one well) in shallow groundwater had significant $($ alpha $=0.05)$ upward trends in 
some parts of the study area. The biosolids-signature results indicate that the aquifers intercepted by the five routinely sampled wells likely have received some recharge through treated (biosolids-applied) fields or biosolids-affected ponds. Adverse effects from this biosolids-related recharge range from few (if any) at one well to large and significantly (alpha $=0.05$ ) increasing nitrate concentrations at another well. The comparison of biosolids-signature results with other waterquality indicators such as regulatory standards and upward trends indicates that (1) the biosolids-signature approach can be useful in differentiating effects, (2) the use of multiple evaluation approaches increases understanding of complex water-quality issues, (3) biosolids-affected groundwater in the study area can have poor to good water quality, and (4) waterquality problems can result from natural sources and processes in the study area, as well as from biosolids applications.

Crops (usually winter wheat) were monitored for concentrations of the priority parameters in mature grain at treated (biosolids-applied) fields and untreated (control) fields. The crop samples were analyzed for the priority parameters. A statistical evaluation of the five paired wheat-grain samples did not indicate any evidence that biosolids applications significantly (alpha $=0.05$ or 0.10 ) increased concentration of any of these constituents in wheat grain. The wheat-grain concentrations from this study were similar to those from other studies for fields in North America where no biosolids were applied. Therefore, the data for the limited crop samples indicate that biosolids applications are not increasing the concentrations of arsenic, cadmium, copper, lead, mercury, molybdenum, nickel, selenium, sulfur, and zinc in mature wheat grain from the study area.

\section{Introduction}

Since 1993, the Metro Wastewater Reclamation District (Metro District), has been applying biosolids that result from the treatment of sewage from the Denver area to the Metro District's property near Deer Trail, Colo. (figs. 1, 2). The Metro District is the wastewater treatment authority for most of metropolitan Denver and serves about 1.7 million people across a 715 -square-mile $\left(\mathrm{mi}^{2}\right)$ service area

(http://www.metrowastewater.com/accessed July 20, 2012). Domestic, commercial, and industrial wastewater is treated by the Metro District, but water from gutters and storm drains is not treated. The wastewater treatment processes that produced the biosolids included primary and secondary treatment, which are described in more detail in the Biosolids section of this report. The biosolids are trucked about 65 to 75 miles (mi) east from Denver to the Metro District property and are applied to nonirrigated farmland. The first property the Metro District acquired near Deer Trail in 1993 was about 15 mi $^{2}$ (fig. 1). In 1995, the Metro District traded some of the property and acquired additional property in the same area. The resulting boundaries of the original property became known as the
Metro District Central property (fig. 2). The new properties consisted of about $14.5 \mathrm{mi}^{2}$, known as the North property, and about $50 \mathrm{mi}^{2}$, known as the South property (fig. 2). In 1999, the three Metro District properties together (known as the METROGRO Farm) encompassed almost $70 \mathrm{mi}^{2}$ of farmland in Arapahoe and Elbert Counties. After 1999, the Metro District property boundaries changed a little; some sections were traded and parts of other sections were acquired.

Biosolids are applied by the Metro District to the METROGRO Farm near Deer Trail (fig. 2) according to agronomic loading rates (Colorado Department of Public Health and Environment, 2003; fig. 3). Land-applied biosolids must meet Colorado regulatory limits (Colorado Department of Public Health and Environment, 2003); otherwise, agronomic loading rates could be exceeded and soils could become overloaded. Soil quality either can be improved by biosolids applications through increased nutrients and organic matter or degraded through accumulation of excessive nutrients, metals, or other chemical constituents. Animal waste (related to wildlife and grazing domestic livestock) and applications of pesticides and fertilizers (organic and inorganic) also can affect soil and water quality (Adeyinka and Mustapha, 2005). Applications to soil also could affect streambed sediment, dust, and crops. Therefore, the U.S. Geological Survey (USGS), in cooperation with Metro Wastewater Reclamation District (Metro District), began a series of monitoring programs to evaluate the effects of biosolids applications to the Metro District properties near Deer Trail, Colo.

\section{Monitoring History}

The USGS has collected data in the vicinity of the METROGRO Farm since 1993. The various USGS monitoring programs considered water quality, hydrology, and the chemical composition of biosolids, streambed sediments, soil, crops, and dust.

From 1993 to 1999, the USGS, in cooperation with the Metro District, monitored water quality on the original Metro District property (fig. 1). The objective of this monitoring program was to evaluate baseline water quality and the combined effects of natural processes, land uses, and biosolids applications on water quality of the biosolids-application area. The monitoring program considered shallow and deeper groundwater, pore water, and surface water but focused on shallow groundwater. Selected monitoring results for 19931999 and a detailed discussion of hydrogeology of the study area were reported by Yager and Arnold (2003).

Public concern about applications of biosolids to farmland increased in the late 1990s after the Metro District agreed to accept treated groundwater from the Lowry Landfill Superfund site in Denver. The concern was that water from the Lowry Superfund site might contain radionuclides that would contaminate the Metro District biosolids, the METROGRO Farm, and surrounding private property. In January 1999, the USGS began an expanded monitoring program that continued 


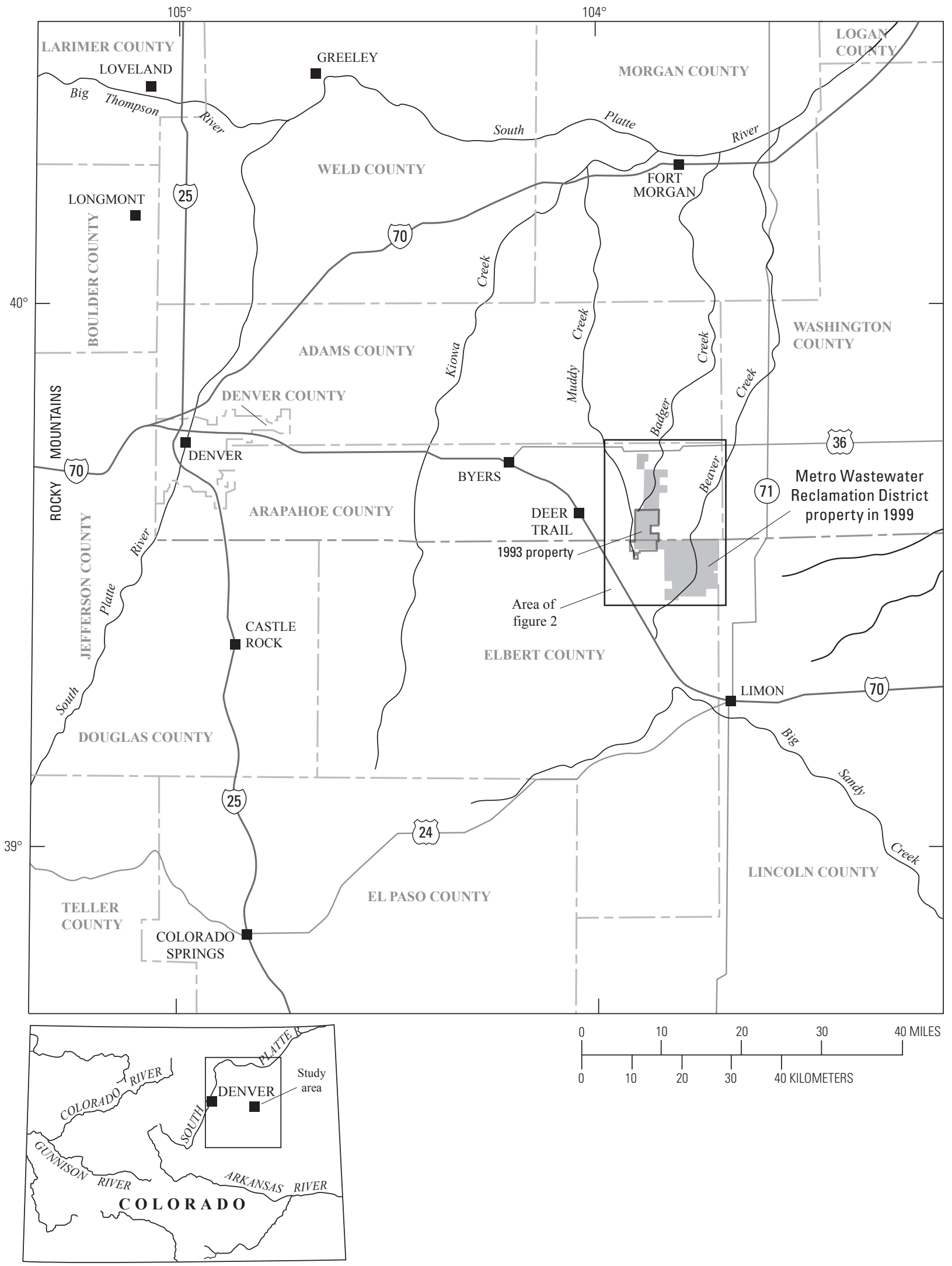

Figure 1. Map showing location of study area near Deer Trail, Colorado. 


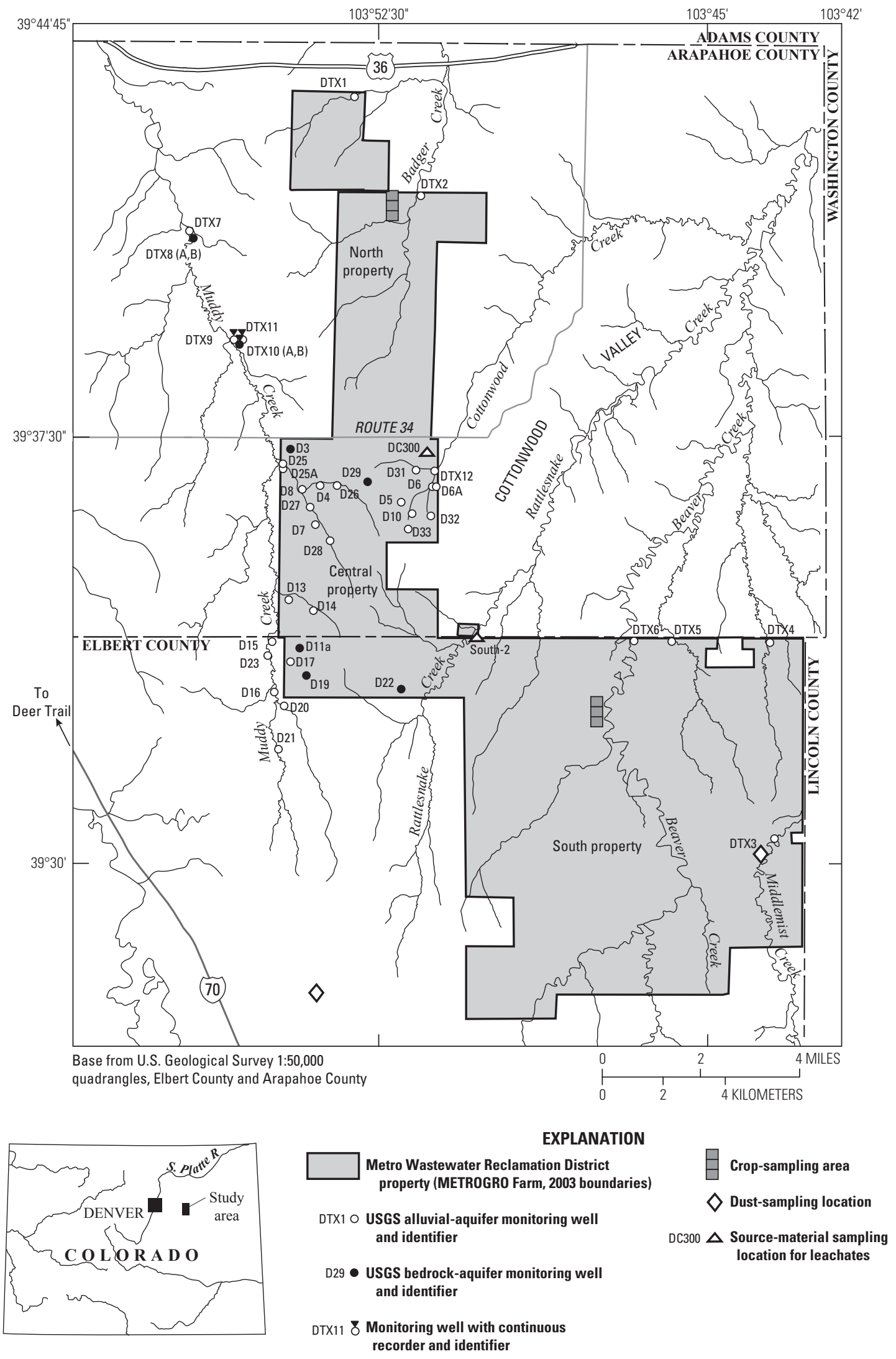

Figure 2. Map showing location of U.S. Geological Survey monitoring sites near Deer Trail, Colorado, 2004-2010. 


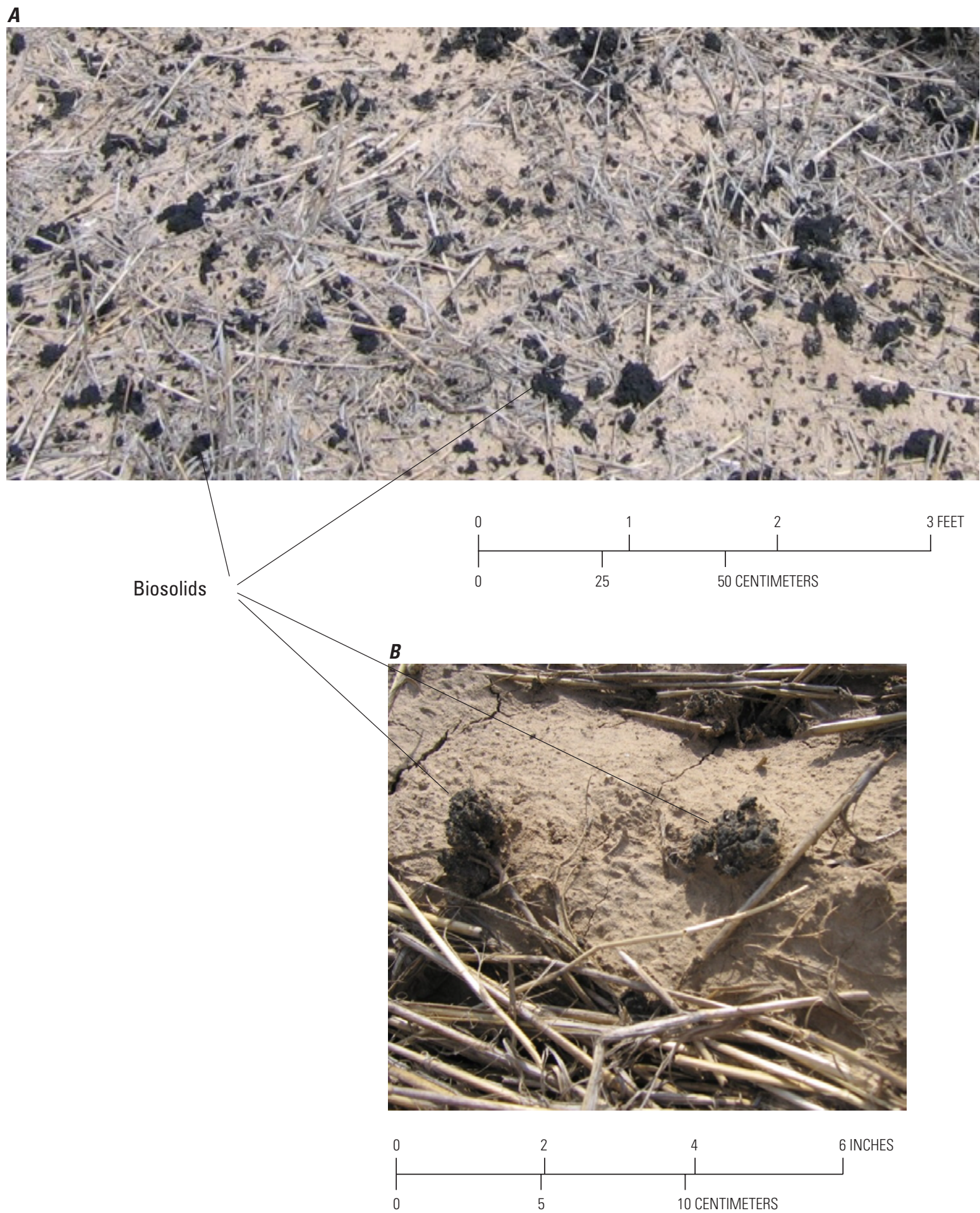

Figure 3. Photographs showing biosolids applied by Metro Wastewater Reclamation District at the agronomic loading rate in eastern Colorado in 2007 at $A$, application day; and $B, 20$ days post-application (photographs from U.S. Geological Survey). 
through 2003 (1999-2003), in cooperation with the Metro District and the North Kiowa Bijou Groundwater Management District, to address this and other concerns from stakeholders. The USGS referred to the 1999-2003 monitoring program as the "expanded monitoring program." The expanded monitoring program near Deer Trail was distinct from, but built on, the first USGS monitoring program near Deer Trail on the Metro District central property (fig. 1). Compared to the previous program (1993-1999), the expanded program included a larger study area (fig. 2; all three Metro District properties and private-property locations), more monitoring components (biosolids, soil, crops, and streambed sediments were monitored in addition to groundwater), a more comprehensive list of chemical constituents, expanded statistical analyses of data, and an extended monitoring period (1999-2003).

The objectives of the USGS expanded monitoring program near Deer Trail during 1999-2003 were to (1) evaluate the combined effects of biosolids applications, land use, and natural processes on the chemical composition of soils, crops, the bedrock aquifer, alluvial aquifers, and streambed sediments by comparing chemical data to (a) regulatory standards, (b) data from a site where biosolids are not applied (a control site), or (c) earlier data from the same site (trends); (2) monitor biosolids for trace elements and plutonium isotopes and compare these concentrations with regulatory standards; and (3) characterize the hydrology of the study area. The monitoring of each component (such as groundwater or crops) was a stand-alone study that did not necessarily encompass the entire study area and time period. Priority parameters were identified by stakeholders and were slightly different for each monitoring component. Priority parameters for each monitoring component included the nine trace elements regulated by Colorado for biosolids (arsenic, cadmium, copper, lead, mercury, molybdenum, nickel, selenium, and zinc). Other constituents and parameters also were analyzed for each monitoring component. Data from the 1999-2003 monitoring program were reported by Stevens and others (2003); Yager, Smith, Crock, and Stevens (2004); and Yager, Smith, and Crock (2004a, 2004b). Additional chemical data for the 1999-2003 monitoring program were reported by Crock, Smith, Yager, Brown, and Adams (2008) and Crock, Smith, and Yager (2009). Selected data for 1999 through 2003 also were published in the "USGS Expanded Monitoring Program near Deer Trail" progress reports (accessed July 19, 2012 at http://co.water.usgs.gov/projects/CO406/pubsprogress. $\mathrm{html}$ ). Interpretive information for the 1999-2003 monitoring program was reported by Yager, Smith, and Crock (2004c).

A subsequent phase of the expanded monitoring program near Deer Trail continued with selected monitoring. The USGS, in cooperation with the Metro District, studied biosolids composition and the effects of biosolids applications on groundwater quality and trace-element concentrations in crops of the Metro District properties near Deer Trail, Colo., during 2004 through 2010 (2004-2010). This study was conducted in response to continued public concern about potential contamination of groundwater and crops from biosolids applications. A scaled-back interim monitoring period in 2004 continued selected aspects of the 1999-2003 phase. Conclusions from the 1999-2003 phase (Yager, Smith, and Crock, 2004c) were used to determine monitoring components, analytes, sites, and sampling frequency for the 2005-2010 monitoring period. During 2004-2010, the monitoring program did not include soil or streambed-sediment monitoring components but did include analysis of nitrogen isotopes to characterize nitrogen sources. A monitoring component to characterize dust also was included for 2006 and 2007 because of stakeholder concerns. The 2004-2010 monitoring program also included organic wastewater compounds (OWCs) in biosolids, biosolids leachates, and groundwater because other studies indicated that OWCs from various anthropogenic activities could persist through wastewater treatment (Kolpin and others, 2002; Verplanck and others, 2003; Lee and others, 2004; Sando and others, 2005; Sando and others, 2006; Kinney and others, 2006; Vajda and others, 2008; Rounds and others, 2009). During the 2004-2010 phase of study, the objectives of the program were to (1) evaluate the combined effects of biosolids applications, land use, and natural processes on the chemical composition of groundwater and crops by comparing chemical data to (a) regulatory standards, (b) data from a site where biosolids are not applied (a control site), or (c) earlier data from the same site (trends); (2) monitor the chemical composition of biosolids and compare concentrations with regulatory standards; and (3) further characterize the hydrology of the study area, particularly for the water-quality context. The monitoring of each component (such as groundwater or crops) was a stand-alone study that did not necessarily encompass the entire study area and time period. Priority parameters for each monitoring component once again included the nine trace elements regulated by Colorado for biosolids (arsenic, cadmium, copper, lead, mercury, molybdenum, nickel, selenium, and zinc). Other constituents and parameters also were analyzed for each monitoring component. More detailed information about the monitoring of these components is included later in this report.

Some results for the 2004-2010 monitoring program have been published and are available to the public. Most of the data from the 2004-2010 monitoring program were reported by Yager, Smith, and Crock $(2009,2011,2012)$. Additional chemical data for the 2004-2010 monitoring program were reported by Crock, Smith, Yager, Berry, and Adams (2008, 2009, 2010, 2011) and Crock, Smith, Yager, Brown, and Adams (2008). Selected data for 2004 through 2010 also were published in the "USGS Expanded Monitoring Program near Deer Trail" progress reports (accessed July 19, 2012 at http://co.water.usgs.gov/projects/CO406/pubsprogress. $h t m l)$. The data and interpretations for the nitrogen source study were reported by Yager and McMahon (2012). Data and interpretations for the dust-monitoring component were reported by Reheis and others (2009). The results for organic 
wastewater compounds in biosolids, biosolids leachates, and groundwater and other interpretive information for the 2004-2010 monitoring program, however, previously were not available to the public.

\section{Purpose and Scope}

The purpose of this report is to present the results for organic wastewater compounds in biosolids, biosolids leachates, and groundwater and other interpretive information about biosolids, groundwater, and crops from the expanded monitoring program near Deer Trail for 2004-2010. In particular, the report discusses effects of biosolids applications on groundwater quality and trace-element concentrations in crops. This report is organized by monitoring component because each component (such as groundwater or crops) was monitored as a separate study. For each monitoring component, component-specific objectives, approaches, and interpretive discussions are included. The interpretive discussions for groundwater and crop components consider geochemical effects as well as effects of biosolids applications on that component. The Biosolids section includes a discussion of biosolids leachates as well as a discussion of a single cow-manure leachate for comparison. The Groundwater section includes a discussion of hydrology as well as water quality, but it does not include the details of the nitrogen source study (reported by Yager and McMahon, 2012). This report also does not include information for the dust monitoring component, which was discussed in another interpretive USGS report (Reheis and others, 2009). The three Metro District properties (the METROGRO Farm; 2003 boundaries) and surrounding private property are considered the study area for this report (fig. 2).

The report contains various appendixes. A map showing the Metro District biosolids-application areas near Deer Trail is included as appendix 1. A comparison of organic wastewater compound data for biosolids and replicate samples collected in 2006 is included as appendix 2; the associated surrogate data and matrix-spike recoveries are listed in appendix 3 . The organic wastewater compounds data (including data for surrogates) and other related data for leachate and groundwater samples associated with the biosolids-application area near Deer Trail in 2005 are included as appendix 4; the associated matrix-spike recoveries are listed in appendix 5 . Well completion and site information for the USGS monitoring wells discussed in this report are included as appendix 6 . The relative standard deviation, absolute difference, and percent difference for the replicate groundwater samples collected during 2004-2010 are included as appendixes 7, 8, and 9. A statistical comparison of concentrations for selected groundwater constituents and regulatory standards is included as appendix 10. A statistical evaluation of time-series trend for selected groundwater constituents during 2004-2010 is included as appendix 11.

\section{Description of Study Area}

The study area is located on Colorado's eastern plains, about 75 mi east of Denver and about 10 mi east of Deer Trail (fig. 1). The study area is in the Colorado Piedmont section of the Great Plains physiographic province, an area characterized as "late mature to old elevated plain" (Fenneman, 1931). Soils in the study area generally are sandy or loamy on flood plains and stream terraces, clayey to loamy on gently sloping to rolling uplands, and sandy and shaley on steeper uplands (Larsen and others, 1966; Larsen and Brown, 1971). The study area generally was vegetated during 2004-2010 except where the land surface was rock or where farm fields were freshly tilled. Crops and prairie vegetation dominated the landscape. Tree canopy was sparse and consisted of primarily deciduous varieties such as cottonwood trees along streams.

Surface water consists of ponds (usually constructed impoundments) and intermittent and ephemeral streams; streams rarely flow except after rain. Groundwater is present in alluvial and bedrock aquifers (Yager and Arnold, 2003). The hydrology of the study area will be discussed in more detail in the Groundwater section of this report.

\section{Topographic Features}

Topographic features of the study area include flood plains, terraces with incised channels, valleys with incised channels, rounded hills, and cliffs. The study area is drained by three major streams (fig 1): Muddy Creek in the west, Badger Creek in the north, and Beaver Creek in the south and east (Seaber and others, 1987). All streams in the study area flow generally north and are within the South Platte drainage basin. Muddy Creek is characterized by a wide, flat flood plain; the stream channel generally is incised less than 10 feet (ft). Within the study area, Badger Creek is characterized by steeper, less incised valleys compared to Muddy Creek. Beaver Creek is the largest stream on the south Metro District property and includes three tributary streams: Cottonwood Creek (drains the east side of the central Metro District property), Rattlesnake Creek (drains the northwest part of the south Metro District property), and Middlemist Creek (drains the southeast corner of the south Metro District property) (fig. 2). Most of the Metro District property drained by Beaver Creek has wide, flat terraces with stream channels incised more than $10 \mathrm{ft}$. Upland (headwaters) parts of streams are characterized by steeper more V-shaped valleys than lowland, downgradient parts of streams. The north and south parts of the study area are characterized by rounded hills and rolling topography. The central part of the study area between Muddy Creek and Rattlesnake Creek (fig. 2) is characterized by steep hills and cliffs. 


\section{Geology}

Geology of the study area is described by Yager and Arnold (2003). In general, the geology of the study area consists of interbedded shale, siltstone, and sandstone, which may be overlain by clay, windblown silt and sand, or alluvial sand and gravel (Sharps, 1980; Major and others, 1983; Robson and Banta, 1995). The study area is on the eastern margin of the Denver Basin, a bowl-shaped sequence of sedimentary rocks. In the study area, the uppermost rock formations are highly eroded Cretaceous-age units that consist of the upper part of the Pierre Shale, the Fox Hills Sandstone, and the lower part of the Laramie Formation. These geologic units were deposited in an ocean or near-shore environment and comprise the Laramie-Fox Hills hydrostratigraphic unit (LFH-HU), and where saturated, the Laramie-Fox Hills aquifer. Maps showing the extent and thickness of the LFH-HU are included in Yager and Arnold (2003). The LFH-HU is present beneath much of the study area, but is not present in the eastern two-thirds of the Metro District's south property, which is underlain by Pierre Shale.

The Pierre Shale crops out and subcrops east of the Metro District central property and consists of dark gray shale with layers of siltstone and fine-grained sandstone. Approximately the upper $200 \mathrm{ft}$ of the Pierre Shale is interbedded with siltstone and sandstone, which gives a striped appearance to core samples. This part of the Pierre Shale is known as the "transition zone" and becomes increasingly sandy toward the top of the formation, forming a gradational contact with the overlying Fox Hills Sandstone. Where the upper part of the Pierre Shale is near land surface, the heterogeneity of the transition zone in the Pierre Shale results in localized shaley or sandy regions within the study area.

The Fox Hills Sandstone consists of massive yelloworange to tan, poorly consolidated, fine-grained sandstone and siltstone. The formation contains thin lenses of coal-rich shale, iron- and calcite-cemented concretions, and trace fossils of burrows. The top of this formation contains well-cemented sandstone in the southern half of the Metro District central property that formed cliff features.

The Laramie Formation consists of an upper part of mostly shale and siltstone with lenses of sandstone and coal, and a lower part of mostly sandstone interbedded with shale and coal. In the study area, the Laramie formation is mostly fine grained, consisting of brown to gray shale containing lenses of sandstone, shale, and coal.

Unconsolidated sediments in the study area are Pleistocene to modern in age and include Peoria Loess, windblown sand deposits, and alluvium. The Peoria Loess covers the bedrock in much of the study area, is covered by modern soil horizons, and may be interbedded with buried soil horizons (Muhs and others, 1999). The maximum observed thickness of unconsolidated sediments that include the Peoria Loess in the study area is about $50 \mathrm{ft}$ (north of well D29 near Route 34; fig. 2). On the Metro District property, the loess consists of fairly homogenous tan to brown windblown clay and silt derived from weathered bedrock and older alluvium and often contains crystalline gypsum. Windblown sand deposits were less than 1-ft thick in the cores obtained from drilling in the study area and are derived from weathered bedrock and alluvium. Alluvium in the study area is present in some places beneath the Peoria Loess in paleochannels and along the flood plains and bottoms of larger stream valleys. Alluvium was less than 1-ft thick in the cores obtained from drilling in the study area. The composition and texture of the alluvium are not homogeneous but range from pink, white, and gray arkosic sands and gravels derived from igneous and metamorphic rock of the Rocky Mountains to dark yellowish gray to tan clay, silt, and sand locally derived from sedimentary rocks.

\section{Climate and Weather}

The climate in the study area is semiarid. Less than 20 inches of precipitation usually is received each year. Most of the precipitation occurs as rainfall in spring (usually in April, May, or early June) and in late summer (usually in mid-July through August). Precipitation data for two sites on the Metro District Central property during 1996 through 1998 were reported by Yager and Arnold (2003). Precipitation data for four sites in the study area during 1999-2003 were reported by Stevens and others (2003) and Yager, Smith, and Crock (2004a, 2004b, and 2004c). Precipitation data for four sites in the study area during 2004-2010 were reported by Yager, Smith, and Crock (2009, 2011, and 2012). A comparison of the various precipitation data for each period indicates that precipitation quantities sometimes differed substantially (as much as 5 inches difference in annual precipitation) over 3 to $4 \mathrm{mi}$ and, in general, more precipitation usually was received in the north part of the study area. Annual precipitation totals measured in the study area varied temporally as well as spatially. During 2004-2010, annual precipitation totals measured in the study area ranged from about 9 inches in 2004 and 2007 to about 18 inches in 2009. Information about the timing of precipitation during 2004-2010 is provided later in the Hydrology section of this report.

Air temperatures in the study area are coldest during winter (December through February) and warmest during summer (June through August). Air-temperature data for the study area during 2004-2010 were reported by Yager, Smith, and Crock (2009, 2011, and 2012). These data indicate that air temperatures were fairly consistent across the study area during 2004-2010. During 2004-2010, daily maximum air temperatures in the study area usually measured between -10 degrees Celsius $\left({ }^{\circ} \mathrm{C}\right)$ and $+35^{\circ} \mathrm{C}$. Daily maximum air temperatures during exceptionally warm periods in July 2005 and June-July 2007 measured between $+35^{\circ} \mathrm{C}$ and $+40^{\circ} \mathrm{C}$. Daily maximum air temperatures occasionally were between $-10^{\circ} \mathrm{C}$ and $-20^{\circ} \mathrm{C}$, such as in December 2005, January 2007, and December 2009. The study area often was windy; prevailing winds were from the north in winter and from the west in 
summer. Average annual pan evaporation in the study area for 1946 through 1955 was about 70 inches (Robson and Banta, 1995, fig. 10).

\section{Land Use}

Land use in the study area historically was rangeland, cropland, and pasture (U.S. Geological Survey, 1980). Abandoned homesteads and other buildings were present on the Metro District property, along with associated outbuildings, animal pens, and shallow windmill-pumped wells (Yager and Arnold, 2003). No people lived on the Metro District property during 2004-2010. Rural residences in the study area, however, include those west of well D13 near Muddy Creek, north of well D25 near Muddy Creek, north of well DTX6 near Rattlesnake Creek, and north of well DTX2 near Badger Creek. Some petroleum exploration has been done in the area (Drew and others, 1979), but no oil or gas exploration or production took place on the Metro District properties during 2004-2010 (N. Crews, Metro Wastewater Reclamation District, written commun., April 13, 2011). Land use on the Metro District property during 2004-2010 mostly was cropland. Land use within the rest of the study area during 2004 2010 mostly was rangeland or pasture with some cropland. Cropland and rangeland in the study area was not irrigated. Herbicides and other chemicals were applied to the study area during 1999 through 2010 for farming purposes. Pesticides and other fertilizers also may have been applied to the Metro District properties historically, but little information is available about these historical applications. Biosolids were applied as a fertilizer and soil amendment only on the Metro District properties. The primary crop was wheat. Crop information for each of the Metro District property sections was reported by Yager, Smith, and Crock (2009, 2011, and 2012). Cattle and sheep were the primary domestic animals grazing this area. Wildlife observed in the study area included pronghorn, deer, coyotes, herons, hawks, owls, badgers, rodents, and turtles.

\section{Biosolids}

Biosolids are solid organic matter recovered from a sewage-treatment process that meet State and Federal regulatory criteria for beneficial use, such as for fertilizer. The biosolids in this study resulted from municipal wastewater treatment at the Robert W. Hite Treatment Facility operated by the Metro District in Denver, Colo. The wastewater treatment processes that produced the biosolids included trash screening, grit removal, primary clarification, aeration, secondary clarification, and anaerobic digestion (http://www.metrowastewater. com/know/BenReuse/Pages/whatwedo.aspx accessed July 16, 2012), in addition to an industrial pretreatment program, solids concentration and blending, and centrifugation. More information about the sewage-treatment process that resulted in the Metro District biosolids can be found at http://www.metrowastewater.com (accessed on July 19, 2012). Average annual moisture content in the final biosolids ranged from 73 to 88 percent (average of 81 percent) during 19942010 (T. Bayha, Metro Wastewater Reclamation District, written commun., January 11, 2012), although the biosolids appeared as a solid, not a slurry. The biosolids in this study were applied to the soil surface at agronomic loading rates as a fertilizer and soil amendment to farmland near Deer Trail. After application, the biosolids usually were incorporated into the upper 12-18 inches of the soil surface by use of a rotating drum with tines that was pulled behind a tractor; the incorporation step left some biosolids material on top of the land surface, as can be seen in figure 3. Dates of application and application rates provided by the Metro District for their properties near Deer Trail for 2004-2010 were reported by Yager, Smith, and Crock (2009, 2011, and 2012), along with the inorganic chemical data for biosolids.

The biosolids must meet Federal and State regulatory standards (U.S. Environmental Protection Agency, 1993; Colorado Department of Public Health and Environment, 2003). Exceeding these standards could adversely affect the quality of soil on which the biosolids are applied and could alter Metro District plans for the application of biosolids in Arapahoe and Elbert Counties. The regulatory standards for Colorado biosolids are described by Colorado Department of Public Health and Environment (2003) as Table 1 Ceiling Concentration Limits and Table 3 Pollutant Concentration Limits. Table 3 Pollutant Concentration Limits (formerly known as Grade I) are more restrictive than Table 1 Ceiling Concentration Limits (formerly known as Grade II). In this report, "Table 3 biosolids" and "Table 3 Class B biosolids" mean biosolids that meet the criteria in Table 3 of the Colorado biosolids regulation. Land-applied biosolids in Colorado must meet Table 1, Class B criteria (Colorado Department of Public Health and Environment, 2003). The Metro District applied Table 3 Class B biosolids from the Denver area (fig. 1) to their properties near Deer Trail (fig. 2).

\section{Objectives of Monitoring Biosolids}

The chemical composition of biosolids was monitored by the USGS to provide an independently determined data set with which the Metro District's chemical analyses and the regulatory standards for biosolids could be compared. The data also constitute a chemical baseline against which any future change in the concentration of constituents determined in this study might be recognized, measured, and compared. In addition, biosolids were analyzed to determine a chemical biosolids signature that could be used to help evaluate whether Metro District biosolids have affected soils, streambed sediments, groundwater, or surface water near Deer Trail, Colo. 


\section{Approach for Monitoring Biosolids}

To determine the chemical composition of biosolids, samples were collected monthly during 2004-2010 and analyzed for various constituents. Biosolids were sampled directly from the Metro District treatment plant in Denver (fig. 1) rather than from individual trucks or fields near Deer Trail to enable the USGS to obtain a more representative sample. The biosolids samples were obtained directly from the active centrifuges at the Metro District treatment plant as 1- or 2-day composites, and then transported to the USGS laboratories in Denver. The samples were prepared for analysis at the chemical laboratories of the USGS Mineral Resources Program in Denver.

Biosolids samples were analyzed for inorganic constituents: regulated elements, major cations, other cations (including phosphorus), nitrogen, and plutonium isotopes (the isotope $\mathrm{Pu}-238$ and the sum of isotopes $\mathrm{Pu}-239$ and $\mathrm{Pu}-240$ ). Dried and ground monthly biosolids samples routinely were analyzed for concentrations of arsenic, cadmium, copper, lead, mercury, molybdenum, nickel, selenium, and zinc as well as many other cation inorganic constituents at the chemical laboratories of the USGS Mineral Resources Program in Denver. Selected biosolids samples from 2010 also were analyzed for nitrogen (fresh, wet sample) through a contract laboratory (see Yager and McMahon, 2012). At least one monthly biosolids sample each year was analyzed for plutonium isotopes (dried, ground sample) through a contract laboratory. Complete details about the analytical methods and the quality-assurance protocols used for inorganic constituents are described by Yager, Smith, and Crock (2009, 2011, and 2012); Crock, Smith, Yager, Berry, and Adams (2008, 2009, 2010, 2011); Crock, Smith, Yager, Brown, and Adams (2008); or Yager and McMahon (2012). To evaluate the magnitude of concentrations, the concentration data for inorganic constituents in biosolids were compared to applicable Colorado standards for biosolids (Colorado Department of Public Health and Environment, 2003) or to concentrations of soil samples collected during 1999-2003 from parts of the study area not treated with biosolids (Yager, Smith, and Crock, 2004c).

Biosolids samples also were analyzed for OWCs. Selected biosolids samples from 2006 (fresh, wet sample) were analyzed at the USGS National Water Quality Laboratory (NWQL) for three types of OWCs using three different methods: wastewater indicators, pharmaceuticals, and steroid hormones. Wastewater indicators were analyzed by the NWQL on fresh, wet samples by pressurized solvent extraction, solid-phase extraction, and capillary-column gas chromatography/mass spectrometry (Burkhardt and others, 2006). Pharmaceuticals were analyzed by the NWQL on fresh, wet samples that were frozen at $-25^{\circ} \mathrm{C}$ then thawed before analysis; the research method involved pressurized solvent extraction followed by high-performance liquid chromatography coupled with electrospray ionization/quadrupole mass spectrometry similar to that described by Kinney and others (2006). Steroid hormones were analyzed by the NWQL on fresh, wet samples that were frozen at $-25^{\circ} \mathrm{C}$ then thawed before analysis; the research method involved pressurized solvent extraction, solid-phase isolation/cleanup, and analysis by gas chromatography with tandem mass spectrometry analysis as described by Lee and others (2011). Mass spectrometry is an "information-rich" method, so the qualitative identification of a compound at concentrations that are less than the minimum reporting level (MRL) is augmented by other information (Burkhardt and others, 2006; Childress and others, 1999). Analytes in biosolids samples that were positively identified below the MRL and met other quality-control criteria were reported by the laboratory as estimated concentrations because of increased uncertainty in quantitation (Burkhardt and others, 2006; Childress and others, 1999; Rounds and others, 2009). Quality-assurance protocols for processing and analysis of samples for OWCs included contamination-minimization procedures for all personnel (U.S. Geological Survey, variously dated), analysis of replicate samples, preparation and analysis of a matrix spike on a sample replicate, analysis of surrogate compounds with every sample, and analysis of reagent (baked-sand) laboratory blank and laboratory spike samples with every set of prepared samples. The OWC data for the biosolids samples that are included in this report are presented as received from the laboratory, without additional censoring or qualifiers, and were not carbon normalized. To evaluate the magnitude of concentrations, OWCs data from this study were compared to those for biosolids analyzed in other studies (Kinney and others, 2006; U.S. Environmental Protection Agency, 2009).

To determine possible biosolids signatures, chemical data from the analysis of biosolids samples, biosolids leachates, and manure leachates were evaluated. For a possible biosolids signature to indicate the presence of Metro District biosolids in soil and sediment, the chemical-composition data for biosolids were compared to that for untreated soils (soils without biosolids) and rocks of the study area for inorganic constituents (which had natural geochemical sources as well as anthropogenic sources; reported by Yager, Smith, and Crock, 2004c, or Yager and McMahon, 2012) or to MRLs, data for blanks, and matrix-spike data for OWCs (most of which had only anthropogenic sources). For a possible biosolids signature to indicate that Metro District biosolids had affected groundwater or surface water of the study area, leachate data were evaluated. Solid samples collected from the Metro District facility or the METROGRO Farm during 2004-2010 (including fresh-moist/fresh-dried and fresh-dried/field-aged sample pairs) were leached with very clean water (reagent-grade) to see which constituents were mobilized under aqueous conditions (as might happen with precipitation or irrigation on farm fields). The biosolids-leaching experiments during 2004-2010 built on those for the biosolids samples from 2001 for selected inorganic constituents (reported by Yager, Smith, and Crock, 2004c), but included additional analytes (both inorganic and organic) and fresh, wet and field-dried biosolids samples, as well as fresh, lab-dried samples. The leachate experiment done in 2007 was described by Yager and 
McMahon (2012). The leachate experiments done in 2005 are described in this report.

For the leachate experiments done in 2005, selected fresh and dried biosolids samples from 2004 and 2005 and a single cow-manure sample from 2005 were leached. The dried and disaggregated biosolids material (50.0 grams $[\mathrm{g}]$ ) was placed in 1.0 liter (L) of reagent-grade water (which was about $\mathrm{pH}$ 6.8; specific conductance was less than or equal to 3 microsiemens per centimeter at 25 degrees Celsius) at ambient temperature. For wet biosolids samples, an equivalent mass of wet biosolids ( $50 \mathrm{~g}$ dry weight) was placed in sufficient reagent-grade water so that total liquid content of wet biosolids plus reagent-grade water equaled $1.0 \mathrm{~L}$. The mixture was shaken for 5 minutes and allowed to settle for 30 minutes. For analyses of inorganic constituents (anions and cations), the sample was filtered the same day as the leach experiment. This approach is a modification of the Field Leach Test described by Hageman (2007). For analyses of wastewater indicators and pharmaceuticals, the settled sample was filtered the day after the leach experiment. However, the filtration of the leachate from fresh, wet biosolids took 2 days because the sample filtered very slowly, possibly because the filter pores filled up with colloidal material from the biosolids or the polymer used in the wastewater treatment process that produced these biosolids. After filtration for OWC analysis, the leachate samples had some visual characteristics of unfiltered samples, particularly a slight cloudiness that indicated that colloidal sample components passed through the filter. These samples were analyzed without further filtration.

The leachate samples from the 2005 experiment were analyzed for nutrients, major ions, trace elements, and selected OWCs at the USGS laboratories in Denver. Leachate samples were analyzed for cations by using inductively coupled plasma/mass spectrometry. Leachate samples were analyzed for anions by using ion chromatography similar to the method described by Fishman and Friedman (1989). Leachate samples were analyzed for OWCs by using the wastewater-indicator analytical method (polystyrene-divinylbenzene solid-phase extraction and capillary-column gas chromatography/mass spectrometry as detailed by Zaugg and others, 2006) or by using a research pharmaceutical analytical method (solid phase, hydrophilic-lipophilic-balance extraction and highperformance liquid chromatography with mass spectrometry, a method originally developed and published by Cahill and others, 2004, and further validated in Furlong and others, 2008). Because mass spectrometry is an "information-rich" method, analytes in leachate samples that were positively identified below the MRL and met other quality-control criteria were reported as (estimated) concentrations (Childress and others, 1999; Rounds and others, 2009; Zaugg and others, 2006).

Various quality-assurance protocols were used for the leachate samples. Quality-assurance protocols for processing and analysis of leachate samples for inorganic constituents included analysis of replicate samples, equipment-blank samples, and source-solution blank samples. Quality- assurance protocols for processing and analysis of leachate samples for OWCs included contamination-minimization procedures for all personnel (U.S. Geological Survey, variously dated), analysis of replicate samples, preparation and analysis of a matrix spike on a sample replicate, analysis of surrogate compounds with every sample, analysis of a laboratory blank and laboratory spike sample with every set of prepared samples, and analysis of equipment-blank samples and source-solution blank samples. No reagent blank (baked sand) was prepared to quantify bias introduced from the laboratory air during the biosolids drying step. The OWC data for the leachate samples that are included in this report are presented as received from the laboratory.

\section{Composition of Biosolids}

The composition of biosolids was characterized by chemical data for trace elements, major cations, nutrients, plutonium isotopes, and OWCs. The biosolids data are available in Yager, Smith, and Crock $(2009,2011,2012)$, Crock, Smith, Yager, Berry, and Adams (2008, 2009, 2010, 2011); and Crock, Smith, Yager, Brown, and Adams (2008) for trace elements, major cations, phosphorus, and plutonium isotopes; in Yager and McMahon (2012) for nitrogen; and later in this report for OWCs.

\section{Trace Elements and Major Cations}

All concentrations for the priority parameters in the monthly biosolids samples from the Metro District treatment plant during 2004-2010 were less than the maximum allowable concentrations established by Colorado regulatory standards (Table 3 or Table 1 biosolids). Graphs of concentration for each of the priority parameters compared to date of collection are shown in figure 4 . The regulatory limit for Colorado biosolids also is shown on each graph.

The concentration of all nine priority parameters remained relatively consistent throughout the study. Figure 4 indicates that copper and zinc concentrations fluctuated over the largest concentration range (about 500 milligrams per kilogram [mg/kg]) during 2004-2010. Arsenic concentration actually varied the most with its high and low concentration differing by a factor of about 15 . Mercury concentrations also varied substantially with its high and low concentration differing by a factor of about eight. Data for the other seven elements (including copper and zinc) varied by a factor of five or less for 2004-2010.

In addition to the nine elements that have regulatory standards established, the USGS analyzed biosolids samples for many other cation elements including major ions (like calcium, potassium, and sodium) and rare-earth elements. Most of these elements were present in the 2004-2010 biosolids samples at concentrations comparable to those of natural soils in the area or in trace concentrations near or below the MRL (Crock, Smith, Yager, Berry, and Adams, 2008, 2009, 

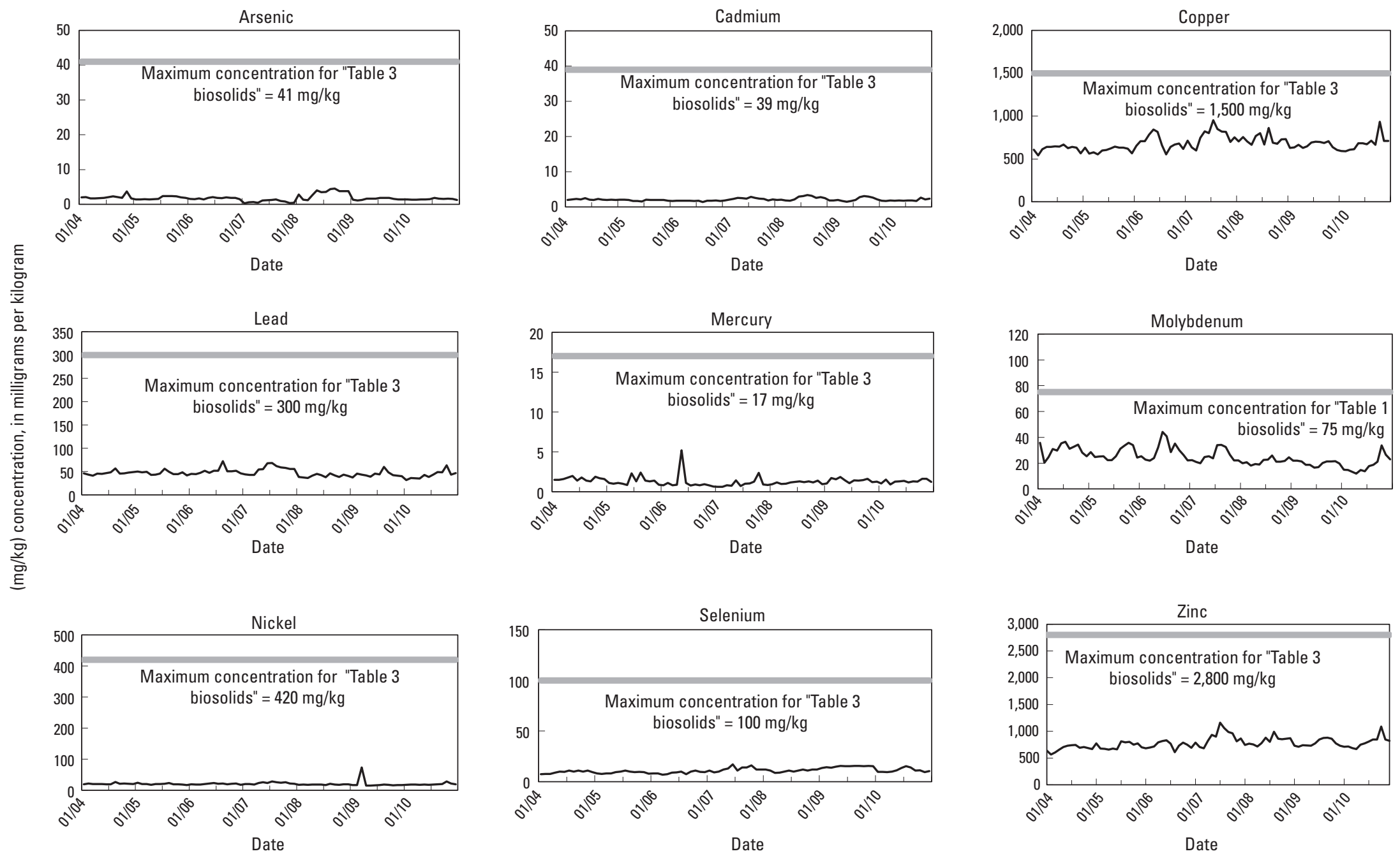

Figure 4. Graphs showing concentrations of regulated elements in biosolids sampled monthly from the Metro Wastewater Reclamation District during 2004 through 2010 compared to Colorado standards for biosolids (Colorado Department of Public Health and Environment, 2003). 
2010, 2011; Crock, Smith, Yager, Brown, and Adams, 2008). Silver and bismuth concentrations in the 2004-2010 biosolids samples, however, were substantial relative to those of natural soils in the area (Yager, Smith, and Crock, 2004c).

\section{Nutrients}

Biosolids samples were analyzed for nitrogen and phosphorus during 2004-2010. Nine biosolids samples from 2004-2010 were analyzed for nitrogen. Yager and McMahon (2012) reported that nitrogen in fresh, wet biosolids samples was primarily of the reduced form (ammonia plus organic nitrogen), and the maximum concentration measured was $71,000 \mathrm{mg} / \mathrm{kg}$ as nitrogen. Phosphorus was analyzed in all monthly biosolids samples from the Metro District (Crock, Smith, Yager, Berry, and Adams, 2008, 2009, 2010, 2011; Crock, Smith, Yager, Brown, and Adams, 2008). At 1.91-4.50 percent by dry weight, total phosphorus concentrations in fresh, dried biosolids samples were substantial. A comparison of the nutrient data for the 2004-2010 biosolids samples with data for other possible nutrient sources indicated that biosolids likely were the largest source of nitrogen and phosphorus on the METROGRO Farm (Yager, Smith, and Crock, 2004c; Yager and McMahon, 2012). This large nutrient content supports the use of biosolids as a plant fertilizer. There are no published regulatory limits for nitrogen or phosphorus in biosolids.

\section{Plutonium Isotopes}

During 2004-2010, at least one monthly biosolids sample was analyzed for plutonium isotopes (the isotope $\mathrm{Pu}-238$ and the sum of isotopes $\mathrm{Pu}-239$ and $\mathrm{Pu}-240$ ). The plutonium-isotope data for the 2004-2010 biosolids samples were reported by Yager, Smith, and Crock $(2009,2011,2012)$; Crock, Smith, Yager, Berry, and Adams (2008, 2009, 2010, 2011); and Crock, Smith, Yager, Brown, and Adams (2008) in the uncensored form as received from the laboratory rather than censored by either the contract or calculated minimum detectable concentration (MDC; McCurdy and others, 2008) or by some other reporting level. Relative to the censored form (data reported as less than a value), the uncensored form provides more information about the uncertainty and the very small concentrations of plutonium isotopes in biosolids. The negative activity concentration reported for the samples means the sample count was less than the laboratory background count for that day. Additional information about the interpretation and reporting of radiological data is available from McCurdy and others (2008).

All the plutonium-isotope data for 2004-2010 were below the MDC with a distribution near zero. There are no published regulatory values for plutonium isotopes in biosolids.

\section{Organic Wastewater Compounds}

Federal and State biosolids regulations for 2004-2010 did not include any OWCs (Colorado Department of Public Health and Environment, 2003). Even though biosolids were not regulated for OWCs at this time, these compounds are of interest because of the largely unknown effects of the compounds individually or collectively (antagonistic or synergistic effects) on the terrestrial ecosystem and the potential for a subset of these compounds to act as a tracer of wastewater occurrence or exposure in the environment.

The suite of compounds called OWCs includes alkylphenols, alkylphenol ethoxylates, other detergent degradates, polycyclic aromatic hydrocarbons (PAHs), disinfectants, fire retardants, fragrances, and other wastewater indicators from personal care products, in addition to sterols, pharmaceuticals, and hormones. OWCs enter the wastewater stream because people use, excrete, or otherwise eliminate these chemicals routinely. Biosolids contain many of these compounds and contain some compounds in large concentration because many such compounds are hydrophobic and partition to clays or organic matter, the predominant components of biosolids (Kinney and others, 2006). Polymers used to separate the liquid and solid wastes during wastewater treatment also may sequester some of these compounds in the solid wastewater phases. Most of these compounds are of anthropogenic origin and have no natural sources in the terrestrial environment where biosolids are applied. However, biogenic sterols (such as coprostanol, cholesterol, beta-sitosterol, and beta-stigmastanol) and the steroidal hormones also have agricultural sources from the manure of grazing animals (Lorenzen and others, 2004; Andaluri and others, 2012) and natural sources from plants (cholesterol, sitosterol, and stigmastanol) or wildlife in the terrestrial environment.

The data for the two fresh biosolids samples that were collected from the Metro District wastewater treatment plant in 2006 and analyzed for OWCs are listed in table 1 . The wet biosolids matrix was more representative of field-applied biosolids than a dried, ground sample but was analytically challenging for OWC analysis. Analyses of surrogates, isotope-dilution standards (IDS), and matrix spikes were used to evaluate matrix effects on the OWC methods and resulting laboratory data. The surrogate, IDS, and matrix-spike results for the Metro District biosolids samples indicate that the wet biosolids matrix caused analytical interference and bias. Ideally, the surrogate, IDS, and matrix-spike recoveries would be about 100 percent plus or minus about 10 percent if the matrix did not cause any problems in the analysis. However, the Metro District biosolids samples had surrogate or IDS recoveries that ranged from 2.35 percent (fluoxetine-d5) to an estimated 288 percent (progesterone-d9) and matrix spike recoveries that ranged from less than 1.0 percent (benzo[a] pyrene, paroxetine) to 516 percent (anthraquinone) in the OWC analyses of the 2006 samples. In the cases where recovery was not reported, high concentrations of the analyte in the unspiked samples relative to the fortification concentration 
Table 1. Comparison of organic wastewater compound data for two fresh biosolids samples collected from the Metro Wastewater Reclamation District and analyzed by the U.S. Geological Survey National Water Quality Laboratory, 2006.

[Concentrations are not normalized to carbon content; associated data for replicates, surrogates, isotope-dilution standards, and matrix spikes are included in appendixes 2 and 3; Metro District, Metro Wastewater Reclamation District; $\mu \mathrm{g} / \mathrm{kg}$, micrograms per kilogram, dry weight; percent content, the mass of the constituent divided by the summed mass of all the organic wastewater compound analytes for that sample, multiplied by 100; OWC, organic wastewater compounds; RPD, relative percent difference, which is defined for environmental sample pairs as [(September sample value - December sample value)/((September sample value + December sample value)/2)] x 100; Min, minimum; Max, maximum; E, value estimated by laboratory; $<$, less than; ND, not determined because data were less than the minimum reporting limit; --, no data; PAH, polycyclic aromatic hydrocarbon; EDC, potential endocrine disrupting compound; $n$, value is less than the minimum reporting level]

\begin{tabular}{|c|c|c|c|c|c|c|c|c|c|c|c|c|}
\hline \multirow{2}{*}{ Constituent } & \multirow{2}{*}{$\begin{array}{c}\text { General use } \\
\text { category } \\
\text { (Lee and others, } \\
\text { 2004) }\end{array}$} & \multicolumn{2}{|c|}{$\begin{array}{c}\text { Metro District } \\
\text { September } 2006 \\
\text { biosolids sample }\end{array}$} & \multicolumn{2}{|c|}{$\begin{array}{c}\text { Metro District } \\
\text { December } 2006 \\
\text { biosolids sample }\end{array}$} & \multicolumn{2}{|c|}{$\begin{array}{c}\text { Summary } \\
\text { statistics for } \\
\text { Metro District samples }\end{array}$} & \multicolumn{2}{|c|}{$\begin{array}{c}\text { Data from } \\
\text { Kinney and others (2006), } \\
\mu \mathrm{gg} / \mathrm{kg}\end{array}$} & \multicolumn{3}{|c|}{$\begin{array}{l}\text { Data (not including qualifiers) from } \\
\text { U.S. Environmental Protection Agency } \\
(2009)\end{array}$} \\
\hline & & $\begin{array}{l}\text { Reported } \\
\text { value, } \\
\mu \mathrm{g} / \mathrm{kg}\end{array}$ & $\begin{array}{l}\text { Percent } \\
\text { content of } \\
\text { OWC }\end{array}$ & $\begin{array}{c}\text { Reported } \\
\text { value, } \\
\mu \mathrm{g} / \mathrm{kg} \\
\end{array}$ & $\begin{array}{l}\text { Percent } \\
\text { content of } \\
\text { OWC }\end{array}$ & $\begin{array}{l}\text { Median } \\
\text { value }\end{array}$ & RPD & $\begin{array}{l}\text { Biosolid H, } \\
\text { 6/2/2003 }\end{array}$ & $\begin{array}{l}\text { Biosolid H, } \\
\text { 1/26/2004 }\end{array}$ & $\begin{array}{l}\text { Number } \\
\text { of detects }\end{array}$ & $\begin{array}{l}\text { Min of } \\
\text { all samples, } \\
\mu \mathrm{g} / \mathrm{kg}\end{array}$ & $\begin{array}{c}\text { Max of } \\
\text { all samples, } \\
\mu \mathrm{gg} / \mathrm{kg}\end{array}$ \\
\hline \multicolumn{13}{|c|}{ Wastewater indicators laboratory method ${ }^{1}$} \\
\hline 1,4-Dichlorobenzene & Pesticide & E849 & 0.02 & $\mathrm{E} 1,300$ & 0.04 & 1,075 & -42 & $<27.6$ & $<27.6$ & -- & -- & -- \\
\hline 1-Methylnaphthalene & PAH & $<1,570$ & $<0.01$ & $<2,240$ & $<0.01$ & ND & ND & 58 & 14 & -- & -- & -- \\
\hline 2,6-Dimethylnaphthalene & PAH & E846 & 0.02 & $<2,240$ & $<0.01$ & ND & ND & 71 & 37 & -- & -- & -- \\
\hline 2-Methylnaphthalene & PAH & $<1,570$ & $<0.01$ & $<2,240$ & $<0.01$ & ND & ND & 66 & 9 & 39 & 10 & 4,600 \\
\hline 3-beta-Coprostanol & Biogenic sterol & $\mathrm{E} 1,100,000$ & 29.83 & $\mathrm{E} 1,070,000$ & 32.04 & $1,085,000$ & 3 & 87,000 & 105,000 & -- & -- & -- \\
\hline 3-Methyl-1H-indole (skatole) & Fragrance & 55,100 & 1.49 & 37,600 & 1.20 & 46,350 & 38 & 270 & 207 & -- & -- & -- \\
\hline $\begin{array}{l}\text { 3-tert-Butyl-4-hydroxy-anisole } \\
\text { (BHA) }\end{array}$ & Antioxidant, EDC & $<4,700$ & $<0.01$ & $<6,710$ & $<0.01$ & ND & ND & -- & -- & -- & -- & -- \\
\hline 4-Cumylphenol & $\begin{array}{l}\text { Detergent } \\
\text { degradate, EDC }\end{array}$ & $<1,570$ & $<0.01$ & $<2,240$ & $<0.01$ & ND & ND & $<33.7$ & $<33.7$ & -- & -- & -- \\
\hline 4-n-Octylphenol & $\begin{array}{l}\text { Detergent } \\
\text { degradate, EDC }\end{array}$ & $<1,570$ & $<0.01$ & $<2,240$ & $<0.01$ & ND & ND & & & -- & -- & -- \\
\hline $\begin{array}{l}\text { 4-Nonylphenol } \\
\text { (sum of all isomers) }\end{array}$ & $\begin{array}{l}\text { Detergent } \\
\text { degradate, EDC }\end{array}$ & $\mathrm{E} 803,000$ & 21.73 & $\mathrm{E} 661,000$ & 21.03 & 732,000 & 19 & 170,000 & 110,000 & -- & -- & -- \\
\hline $\begin{array}{l}\text { 4-Nonylphenol diethoxylate } \\
\text { (sum of all isomers) (NPEO2) }\end{array}$ & $\begin{array}{l}\text { Detergent } \\
\text { degradate, EDC }\end{array}$ & $\mathrm{E} 43,400$ & 1.18 & E59,400 & 1.89 & 51,400 & -31 & 7,400 & 1,750 & -- & -- & -- \\
\hline $\begin{array}{l}\text { 4-Nonylphenol monoethoxylate } \\
\text { (sum of all isomers) (NPEO1) }\end{array}$ & $\begin{array}{l}\text { Detergent } \\
\text { degradate, } \mathrm{EDC}^{2}\end{array}$ & E78,200 & 2.12 & $\mathrm{E} 43,000$ & 1.32 & 60,600 & 58 & 7,100 & 5,670 & -- & -- & -- \\
\hline 4-tert-Octylphenol & $\begin{array}{l}\text { Detergent } \\
\text { degradate, EDC }\end{array}$ & 14,700 & 0.40 & 15,300 & 0.49 & 15,000 & -4 & 1,400 & 1,010 & -- & -- & -- \\
\hline $\begin{array}{l}\text { 4-tert-Octylphenol diethoxylate } \\
\text { (OPEO2) }\end{array}$ & $\begin{array}{l}\text { Detergent } \\
\text { degradate, EDC }\end{array}$ & $<8,070$ & $<0.01$ & $<2,240$ & $<0.01$ & ND & ND & -- & -- & -- & -- & -- \\
\hline $\begin{array}{l}\text { 4-tert-Octylphenol } \\
\text { monoethoxylate (OPEO1) }\end{array}$ & $\begin{array}{l}\text { Detergent } \\
\text { degradate, EDC }\end{array}$ & $<7,830$ & $<0.01$ & $<11,200$ & $<0.01$ & ND & ND & -- & -- & -- & -- & -- \\
\hline 9,10-Anthraquinone & PAH derivative & $<1,570$ & $<0.01$ & $<2,240$ & $<0.01$ & ND & ND & $<24.3$ & $<24.3$ & -- & -- & -- \\
\hline Acetophenone & Fragrance & $\mathrm{E} 1,690$ & 0.05 & $\mathrm{E} 2,270$ & 0.07 & 1,980 & -29 & 130 & 62 & -- & -- & -- \\
\hline $\begin{array}{l}\text { Acetylhexamethyltetra- } \\
\text { hydronaphthalene (AHTN) }\end{array}$ & Fragrance, EDC & 6,120 & 0.17 & 5,410 & 0.17 & 5,765 & 12 & 4,700 & 5,200 & -- & -- & -- \\
\hline Anthracene & PAH & $<1,570$ & $<0.01$ & $<2,240$ & $<0.01$ & ND & ND & 28 & 16 & -- & -- & -- \\
\hline Atrazine & Pesticide & $<3,130$ & $<0.01$ & $<4,470$ & $<0.01$ & ND & ND & -- & -- & -- & -- & -- \\
\hline Benzo[a]pyrene & PAH, EDC & $<1,570$ & $<0.01$ & $<2,240$ & $<0.01$ & ND & ND & $<24.6$ & $<24.6$ & 64 & 63 & 4,500 \\
\hline Benzophenone & Other & 2,450 & 0.07 & E2,150 & 0.07 & 2,300 & 13 & 410 & 220 & -- & -- & -- \\
\hline beta-Sitosterol & $\begin{array}{l}\text { Biogenic sterol, } \\
\text { EDC }\end{array}$ & E353,000 & 9.57 & E365,000 & 11.20 & 359,000 & -3 & 24,000 & 42,300 & 73 & 24,400 & $1,640,000$ \\
\hline beta-Stigmastanol & Biogenic sterol & $\mathrm{E} 225,000$ & 6.10 & E60,000 & 1.84 & 142,500 & 116 & 13,000 & 11,000 & 83 & 3,440 & $1,330,000$ \\
\hline $\begin{array}{l}\text { bis(2-Ethylhexyl) phthalate } \\
\text { (DEHP) }\end{array}$ & Plastic, EDC ${ }^{2}$ & 90,600 & 2.46 & 41,000 & 1.26 & 65,800 & 75 & 5,800 & 6,870 & 84 & 657 & 310,000 \\
\hline
\end{tabular}


Table 1. Comparison of organic wastewater compound data for two fresh biosolids samples collected from the Metro Wastewater Reclamation District and analyzed by the U.S. Geological Survey National Water Quality Laboratory, 2006. - Continued

[Concentrations are not normalized to carbon content; associated data for replicates, surrogates, isotope-dilution standards, and matrix spikes are included in appendixes 2 and 3; Metro District, Metro Wastewater Reclamation District; $\mu \mathrm{g} / \mathrm{kg}$, micrograms per kilogram, dry weight; percent content, the mass of the constituent divided by the summed mass of all the organic wastewater compound analytes for that sample, multiplied by 100; OWC, organic wastewater compounds; RPD, relative percent difference, which is defined for environmental sample pairs as [(September sample value - December sample value $) /($ September sample value + December sample value)/2)] x 100; Min, minimum; Max, maximum; E, value estimated by laboratory; <, less than; ND, not determined because data were less than the minimum reporting limit; --, no data; PAH, polycyclic aromatic hydrocarbon; EDC, potential endocrine disrupting compound; n, value is less than the minimum reporting level]

\begin{tabular}{|c|c|c|c|c|c|c|c|c|c|c|c|c|}
\hline \multirow{2}{*}{ Constituent } & \multirow{2}{*}{$\begin{array}{c}\text { General use } \\
\text { category } \\
\text { (Lee and others, } \\
\text { 2004) }\end{array}$} & \multicolumn{2}{|c|}{$\begin{array}{c}\text { Metro District } \\
\text { September } 2006 \\
\text { biosolids sample }\end{array}$} & \multicolumn{2}{|c|}{$\begin{array}{c}\text { Metro District } \\
\text { December } 2006 \\
\text { biosolids sample }\end{array}$} & \multicolumn{2}{|c|}{$\begin{array}{c}\text { Summary } \\
\text { statistics for } \\
\text { Metro District samples }\end{array}$} & \multicolumn{2}{|c|}{$\begin{array}{c}\text { Data from } \\
\text { Kinney and others (2006), } \\
\mu \mathrm{g} / \mathrm{kg}\end{array}$} & \multicolumn{3}{|c|}{$\begin{array}{l}\text { Data (not including qualifiers) from } \\
\text { U.S. Environmental Protection Agency } \\
\text { (2009) }\end{array}$} \\
\hline & & $\begin{array}{l}\text { Reported } \\
\text { value, } \\
\mu \mathrm{g} / \mathrm{kg}\end{array}$ & $\begin{array}{l}\text { Percent } \\
\text { content of } \\
\text { OWC }\end{array}$ & $\begin{array}{c}\text { Reported } \\
\text { value, } \\
\mu \mathrm{g} / \mathrm{kg} \\
\end{array}$ & $\begin{array}{l}\text { Percent } \\
\text { content of } \\
\text { OWC }\end{array}$ & $\begin{array}{l}\text { Median } \\
\text { value }\end{array}$ & RPD & $\begin{array}{c}\text { Biosolid H, } \\
\text { 6/2/2003 }\end{array}$ & $\begin{array}{c}\text { Biosolid H, } \\
\text { 1/26/2004 }\end{array}$ & $\begin{array}{c}\text { Number } \\
\text { of detects }\end{array}$ & $\begin{array}{l}\text { Min of } \\
\text { all samples, } \\
\mu \mathrm{gg} / \mathrm{kg}\end{array}$ & $\begin{array}{c}\text { Max of } \\
\text { all samples, } \\
\mu \mathrm{g} / \mathrm{kg}\end{array}$ \\
\hline \multicolumn{13}{|c|}{ Wastewater indicators laboratory method'-Continued } \\
\hline Bisphenol A & Plastic, EDC & E18,700 & 0.51 & E10,200 & 0.31 & 14,450 & 59 & 100 & 547 & -- & -- & -- \\
\hline Bromacil & Pesticide & $<15,700$ & $<0.01$ & $<22,400$ & $<0.01$ & ND & ND & -- & -- & -- & -- & -- \\
\hline Camphor & Fragrance & $<1,570$ & $<0.01$ & $<2,240$ & $<0.01$ & ND & ND & -- & -- & -- & -- & -- \\
\hline Carbazole & Pesticide & $<1,570$ & $<0.01$ & $<2,240$ & $<0.01$ & ND & ND & -- & -- & -- & -- & -- \\
\hline Chlorpyrifos & Pesticide & $<1,570$ & $<0.01$ & $<2,240$ & $<0.01$ & ND & ND & -- & -- & -- & -- & -- \\
\hline Cholesterol & Biogenic sterol & $\mathrm{E} 580,000$ & 15.73 & $\mathrm{E} 511,000$ & 15.68 & 545,500 & 13 & 74,000 & 123,000 & 81 & 18,700 & $5,390,000$ \\
\hline Diazinon & Pesticide, EDC & $<1,570$ & $<0.01$ & $<2,240$ & $<0.01$ & ND & ND & -- & -- & -- & -- & -- \\
\hline Diethyl phthalate & Plastic, EDC ${ }^{2}$ & $<3,130$ & $<0.01$ & 4,830 & 0.15 & ND & ND & -- & -- & -- & -- & -- \\
\hline d-Limonene & Fragrance & E6,190 & 0.17 & $\mathrm{E} 5,510$ & 0.17 & 5,850 & 12 & 220 & 150 & -- & -- & -- \\
\hline Fluoranthene & $\mathrm{PAH}$ & $<1,570$ & $<0.01$ & $\mathrm{E} 1,640$ & 0.05 & ND & ND & 62 & 36 & 77 & 10 & 4,600 \\
\hline $\begin{array}{l}\text { Hexahydrohexamethyl- } \\
\text { cyclopentabenzopyran } \\
\text { (HHCB) }\end{array}$ & Fragrance & 55,840 & 1.51 & 32,000 & 0.98 & 43,920 & 54 & 1,100 & 767 & -- & -- & -- \\
\hline Indole & Fragrance & 12,600 & 0.34 & 25,500 & 0.78 & 19,050 & -68 & 980 & 3,170 & -- & -- & -- \\
\hline Isoborneol & Fragrance & $<1,570$ & $<0.01$ & $<2,240$ & $<0.01$ & ND & ND & -- & -- & -- & -- & -- \\
\hline Isophorone & Solvent & $<1,570$ & $<0.01$ & $<2,240$ & $<0.01$ & ND & ND & -- & -- & -- & -- & -- \\
\hline Isopropylbenzene & Solvent & $<3,130$ & $<0.01$ & $<4,470$ & $<0.01$ & ND & ND & -- & -- & -- & -- & -- \\
\hline Isoquinoline & Flavor & $<3,130$ & $<0.01$ & $<4,470$ & $<0.01$ & ND & ND & -- & -- & -- & -- & -- \\
\hline Menthol & Flavor & $<1,570$ & $<0.01$ & $\mathrm{E} 1,870$ & 0.06 & ND & ND & -- & -- & -- & -- & -- \\
\hline Metolachlor & Pesticide, EDC ${ }^{2}$ & $<1,570$ & $<0.01$ & $<2,240$ & $<0.01$ & ND & ND & -- & -- & -- & -- & -- \\
\hline $\begin{array}{l}\text { N,N-diethyl-meta-toluamide } \\
\text { (DEET) }\end{array}$ & Pesticide & $<3,130$ & $<0.01$ & $<4,470$ & $<0.01$ & ND & ND & -- & -- & -- & -- & -- \\
\hline Naphthalene & PAH & $<1,570$ & $<0.01$ & $<2,240$ & $<0.01$ & ND & ND & 63 & 17 & -- & -- & -- \\
\hline p-Cresol & Other, EDC ${ }^{2}$ & 125,000 & 3.39 & 40,800 & 1.25 & 82,900 & 102 & 1,900 & 707 & -- & -- & -- \\
\hline Phenanthrene & $\mathrm{PAH}$ & $<1,570$ & $<0.01$ & $<2,240$ & $<0.01$ & ND & ND & 59 & 39 & -- & -- & -- \\
\hline Phenol & Disinfectant & $\mathrm{E} 47,300$ & 1.28 & E91,100 & 2.80 & 69,200 & -63 & 1,700 & 953 & -- & -- & -- \\
\hline Prometon & Pesticide & $<1,570$ & $<0.01$ & $<2,240$ & $<0.01$ & ND & ND & -- & -- & -- & -- & -- \\
\hline Pyrene & $\mathrm{PAH}$ & $<1,570$ & $<0.01$ & 3,390 & 0.10 & ND & ND & 64 & 36 & 72 & 44 & 14,000 \\
\hline Tributyl phosphate & Fire retardant & $<1,570$ & $<0.01$ & $<2,240$ & $<0.01$ & ND & ND & -- & -- & -- & -- & -- \\
\hline Triclosan & Disinfectant & 51,600 & 1.40 & 43,100 & 1.32 & 47,350 & 18 & 3,500 & 3,230 & 79 & 430 & 133,000 \\
\hline Triphenyl phosphate & Plastic & $<1,570$ & $<0.01$ & $<2,240$ & $<0.01$ & ND & ND & -- & -- & -- & -- & -- \\
\hline $\begin{array}{l}\text { Tris(2-butoxyethyl) } \\
\text { phosphate (TBEP) }\end{array}$ & Fire retardant & $\mathrm{E} 13,600$ & 0.37 & $\mathrm{E} 4,010$ & 0.12 & 8,805 & 109 & -- & -- & -- & -- & -- \\
\hline $\begin{array}{l}\text { Tris(2-chloroethyl) } \\
\text { phosphate }\end{array}$ & Fire retardant & $<3,130$ & $<0.01$ & $<4,470$ & $<0.01$ & ND & ND & -- & -- & -- & -- & -- \\
\hline $\begin{array}{l}\text { Tris(dichloroisopropyl) } \\
\text { phosphate }\end{array}$ & Fire retardant & $<3,130$ & $<0.01$ & $<4,470$ & $<0.01$ & ND & ND & -- & -- & -- & -- & -- \\
\hline
\end{tabular}

phosphate 
Table 1. Comparison of organic wastewater compound data for two fresh biosolids samples collected from the Metro Wastewater Reclamation District and analyzed by the U.S. Geological Survey National Water Quality Laboratory, 2006.-Continued

[Concentrations are not normalized to carbon content; associated data for replicates, surrogates, isotope-dilution standards, and matrix spikes are included in appendixes 2 and 3; Metro District, Metro Wastewater Reclamation District; $\mu \mathrm{g} / \mathrm{kg}$, micrograms per kilogram, dry weight; percent content, the mass of the constituent divided by the summed mass of all the organic wastewater compound analytes for that sample, multiplied by 100; OWC, organic wastewater compounds; RPD, relative percent difference, which is defined for environmental sample pairs as [(September sample value - December sample value)/((September sample value + December sample value)/2)] x 100; Min, minimum; Max, maximum; E, value estimated by laboratory; <, less than; ND, not determined because data were less than the minimum reporting limit; --, no data; PAH, polycyclic aromatic hydrocarbon; EDC, potential endocrine disrupting compound; n, value is less than the minimum reporting level]

\begin{tabular}{|c|c|c|c|c|c|c|c|c|c|c|c|c|}
\hline \multirow{2}{*}{ Constituent } & \multirow{2}{*}{$\begin{array}{c}\text { General use } \\
\text { category } \\
\text { (Lee and others, } \\
\text { 2004) }\end{array}$} & \multicolumn{2}{|c|}{$\begin{array}{c}\text { Metro District } \\
\text { September } 2006 \\
\text { biosolids sample }\end{array}$} & \multicolumn{2}{|c|}{$\begin{array}{c}\text { Metro District } \\
\text { December } 2006 \\
\text { biosolids sample }\end{array}$} & \multicolumn{2}{|c|}{$\begin{array}{c}\text { Summary } \\
\text { statistics for } \\
\text { Metro District samples }\end{array}$} & \multicolumn{2}{|c|}{$\begin{array}{c}\text { Data from } \\
\text { Kinney and others (2006), } \\
\mu \mathrm{g} / \mathrm{kg} \\
\end{array}$} & \multicolumn{3}{|c|}{$\begin{array}{l}\text { Data (not including qualifiers) from } \\
\text { U.S. Environmental Protection Agency } \\
\text { (2009) }\end{array}$} \\
\hline & & $\begin{array}{l}\text { Reported } \\
\text { value, } \\
\mu \mathrm{g} / \mathrm{kg}\end{array}$ & $\begin{array}{l}\text { Percent } \\
\text { content of } \\
\text { OWC }\end{array}$ & $\begin{array}{l}\text { Reported } \\
\text { value, } \\
\mu \mathrm{g} / \mathrm{kg}\end{array}$ & $\begin{array}{l}\text { Percent } \\
\text { content of } \\
\text { OWC }\end{array}$ & $\begin{array}{l}\text { Median } \\
\text { value }\end{array}$ & RPD & $\begin{array}{c}\text { Biosolid H, } \\
\text { 6/2/2003 }\end{array}$ & $\begin{array}{c}\text { Biosolid H, } \\
\text { 1/26/2004 }\end{array}$ & $\begin{array}{c}\text { Number } \\
\text { of detects }\end{array}$ & $\begin{array}{c}\text { Min of } \\
\text { all samples, } \\
\mu \mathrm{g} / \mathrm{kg}\end{array}$ & $\begin{array}{c}\text { Max of } \\
\text { all samples, } \\
\mu \mathrm{g} / \mathrm{kg}\end{array}$ \\
\hline \multicolumn{13}{|c|}{ Pharmaceuticals laboratory method ${ }^{3}$} \\
\hline 1,7-Dimethylxanthine & Pharmaceutical & -- & -- & $<4.1$ & $<0.01$ & -- & -- & 480 & $<2$ & 4 & 1,130 & 9,580 \\
\hline Acetaminophen & Pharmaceutical & -- & -- & $\mathrm{E} 1,100$ & 0.04 & -- & -- & 70 & $<0.76$ & 2 & 1,120 & 1,300 \\
\hline Caffeine & Pharmaceutical & -- & -- & $<2.6$ & $<0.01$ & -- & -- & 38 & 61 & 39 & 65.1 & 1,110 \\
\hline Carbamazepine & Pharmaceutical & -- & -- & 12 & $<0.01$ & -- & -- & 26 & 44 & 80 & 8.74 & 6,630 \\
\hline Cimetidine & Pharmaceutical & -- & -- & E5.2 & $<0.01$ & -- & -- & 71 & $<0.88$ & 74 & 7.59 & 9,780 \\
\hline Citalopram & Pharmaceutical & -- & -- & 15 & $<0.01$ & -- & -- & -- & -- & -- & -- & -- \\
\hline Codeine & Pharmaceutical & -- & -- & $<2.6$ & $<0.01$ & -- & -- & $<1.3$ & $<1.3$ & 20 & 9.59 & 328 \\
\hline Cotinine & Pharmaceutical & -- & -- & E,n0.97 & $<0.01$ & -- & -- & 28 & 15 & 39 & 11.4 & 690 \\
\hline Dehydronifedipine & Pharmaceutical & -- & -- & $<3.4$ & $<0.01$ & -- & -- & 21 & $<1.7$ & 19 & 3.48 & 24.6 \\
\hline Diltiazem & Pharmaceutical & -- & -- & E,n3.0 & $<0.01$ & -- & -- & $<1.5$ & 6 & 69 & 1.39 & 225 \\
\hline Diphenhydramine & Pharmaceutical & -- & -- & 130 & $<0.01$ & -- & -- & 250 & 250 & 84 & 36.7 & 5,730 \\
\hline Duloxetine & Pharmaceutical & -- & -- & 1.2 & $<0.01$ & -- & -- & -- & -- & - & -- & - \\
\hline Erythromycin & Pharmaceutical & -- & -- & $<3.3$ & $<0.01$ & -- & -- & $<1.7$ & $<1.7$ & 77 & 3.1 & 180 \\
\hline Fluoxetine & Pharmaceutical & -- & -- & 7.4 & $<0.01$ & -- & -- & 65 & 25 & 79 & 12.4 & 3,130 \\
\hline Miconazole & Pharmaceutical & -- & -- & E46 & $<0.01$ & -- & -- & 320 & 330 & 80 & 14.2 & 9,210 \\
\hline Paroxetine & Pharmaceutical & -- & -- & 7.5 & $<0.01$ & -- & -- & -- & -- & -- & -- & -- \\
\hline Ranitidine & Pharmaceutical & -- & -- & $\mathrm{E}<2.2$ & $<0.01$ & -- & -- & -- & -- & 46 & 3.83 & 2,250 \\
\hline Salbutamol (albuterol) & Pharmaceutical & -- & -- & $<2.2$ & $<0.01$ & -- & -- & $<1.1$ & $<1.1$ & 1 & 23.2 & 23.2 \\
\hline Sertraline & Pharmaceutical & -- & -- & 16 & $<0.01$ & -- & -- & -- & -- & -- & -- & -- \\
\hline Sulfamethoxazole & Antibiotic & -- & -- & $<3.2$ & $<0.01$ & -- & -- & $<1.6$ & $<1.6$ & 30 & 3.91 & 651 \\
\hline Thiabendazole & Pharmaceutical & -- & -- & $<2.1$ & $<0.01$ & -- & -- & 1 & $<1$ & 58 & 8.42 & 239 \\
\hline Trimethoprim & Antibiotic & -- & -- & $<2.9$ & $<0.01$ & -- & -- & $<1.5$ & $<1.5$ & 24 & 12.4 & 204 \\
\hline Venlafaxine & Pharmaceutical & -- & -- & 96 & $<0.01$ & -- & -- & -- & -- & -- & -- & -- \\
\hline
\end{tabular}


Table 1. Comparison of organic wastewater compound data for two fresh biosolids samples collected from the Metro Wastewater Reclamation District and analyzed by the U.S. Geological Survey National Water Quality Laboratory, 2006.-Continued

[Concentrations are not normalized to carbon content; associated data for replicates, surrogates, isotope-dilution standards, and matrix spikes are included in appendixes 2 and 3; Metro District, Metro Wastewater Reclamation District; $\mu \mathrm{g} / \mathrm{kg}$, micrograms per kilogram, dry weight; percent content, the mass of the constituent divided by the summed mass of all the organic wastewater compound analytes for that sample, multiplied by 100; OWC, organic wastewater compounds; RPD, relative percent difference, which is defined for environmental sample pairs as [(September sample value - December sample value)/((Septembe sample value + December sample value)/2)] x 100; Min, minimum; Max, maximum; E, value estimated by laboratory; <, less than; ND, not determined because data were less than the minimum reporting limit; --, no data; PAH, polycyclic aromatic hydrocarbon; EDC, potential endocrine disrupting compound; $\mathrm{n}$, value is less than the minimum reporting level]

\begin{tabular}{|c|c|c|c|c|c|c|c|c|c|c|c|c|}
\hline \multirow{2}{*}{ Constituent } & \multirow{2}{*}{$\begin{array}{c}\text { General use } \\
\text { category } \\
\text { (Lee and others, } \\
\text { 2004) }\end{array}$} & \multicolumn{2}{|c|}{$\begin{array}{c}\text { Metro District } \\
\text { September } 2006 \\
\text { biosolids sample }\end{array}$} & \multicolumn{2}{|c|}{$\begin{array}{l}\text { Metro District } \\
\text { December } 2006 \\
\text { biosolids sample }\end{array}$} & \multicolumn{2}{|c|}{$\begin{array}{c}\text { Summary } \\
\text { statistics for } \\
\text { Metro District samples }\end{array}$} & \multicolumn{2}{|c|}{$\begin{array}{c}\text { Data from } \\
\text { Kinney and others (2006), } \\
\mu \mathrm{g} / \mathrm{kg}\end{array}$} & \multicolumn{3}{|c|}{$\begin{array}{l}\text { Data (not including qualifiers) from } \\
\text { U.S. Environmental Protection Agency } \\
\text { (2009) }\end{array}$} \\
\hline & & $\begin{array}{l}\text { Reported } \\
\text { value, } \\
\mu \mathrm{g} / \mathrm{kg}\end{array}$ & $\begin{array}{l}\text { Percent } \\
\text { content of } \\
\text { OWC }\end{array}$ & $\begin{array}{l}\text { Reported } \\
\text { value, } \\
\mu \mathrm{g} / \mathrm{kg}\end{array}$ & $\begin{array}{l}\text { Percent } \\
\text { content of } \\
\text { OWC }\end{array}$ & $\begin{array}{l}\text { Median } \\
\text { value }\end{array}$ & RPD & $\begin{array}{c}\text { Biosolid H, } \\
\text { 6/2/2003 }\end{array}$ & $\begin{array}{c}\text { Biosolid H, } \\
\text { 1/26/2004 }\end{array}$ & $\begin{array}{l}\text { Number } \\
\text { of detects }\end{array}$ & $\begin{array}{c}\text { Min of } \\
\text { all samples, } \\
\mu \mathrm{g} / \mathrm{kg}\end{array}$ & $\begin{array}{c}\text { Max of } \\
\text { all samples, } \\
\mu \mathrm{gg} / \mathrm{kg}\end{array}$ \\
\hline \multicolumn{13}{|c|}{ Pharmaceuticals laboratory method ${ }^{3}$} \\
\hline Warfarin & Pharmaceutical & -- & -- & $<2.5$ & $<0.01$ & -- & -- & 38 & $<1.3$ & 0 & ND & ND \\
\hline \multicolumn{13}{|c|}{ Hormones laboratory method ${ }^{4}$} \\
\hline 3-beta-Coprostanol & Biogenic sterol & $\mathrm{E} 841,600$ & 529.83 & E1,622,000 & 532.04 & $1,231,800$ & -63 & 87,000 & 105,000 & -- & -- & -- \\
\hline 4-Androstene-3,17-dione & Hormone & 488 & 0.01 & 853 & 0.03 & 671 & -54 & -- & -- & -- & -- & -- \\
\hline 11-Ketotestosterone & Hormone & $<1$ & $<0.01$ & 24.3 & $<0.01$ & ND & ND & -- & -- & -- & -- & -- \\
\hline 17-alpha-Estradiol & Hormone, EDC & $<3.5$ & $<0.01$ & 13.9 & $<0.01$ & ND & ND & -- & -- & 5 & 16.1 & 48.8 \\
\hline 17-alpha-Ethynylestradiol & Hormone, EDC & $<1$ & $<0.01$ & $<6.7$ & $<0.01$ & ND & ND & -- & -- & 0 & ND & ND \\
\hline 17-beta-Estradiol & Hormone, EDC & 1.6 & $<0.01$ & $<6$ & $<0.01$ & ND & ND & -- & -- & 11 & 22 & 355 \\
\hline cis-Androsterone & Hormone & 37.2 & $<0.01$ & 269 & 0.01 & 153 & -163 & -- & -- & 50 & 21.3 & 1,030 \\
\hline Cholesterol & Biogenic sterol & E638,200 & ${ }^{5} 15.73$ & $\mathrm{E} 1,441,000$ & ${ }^{5} 15.68$ & $1,039,600$ & -77 & 74,000 & 123,000 & 81 & 18,700 & $5,390,000$ \\
\hline Dihydrotestosterone & Hormone & 8.97 & $<0.01$ & 23.4 & $<0.01$ & 16 & -112 & -- & -- & -- & -- & -- \\
\hline Epitestosterone & Hormone & $<15.8$ & $<0.01$ & 41 & $<0.01$ & ND & ND & -- & -- & -- & -- & -- \\
\hline Equilenin & Hormone, EDC & 29.2 & $<0.01$ & $<67$ & $<0.01$ & ND & ND & -- & -- & 1 & 60.6 & 60.6 \\
\hline Equilin & Hormone, EDC & $<560$ & 0.02 & $<833$ & $<0.01$ & ND & ND & -- & -- & 15 & 22.3 & 107 \\
\hline Estriol & Hormone, EDC & 2.33 & $<0.01$ & 9.13 & $<0.01$ & 6 & -119 & -- & -- & 18 & 7.56 & 232 \\
\hline Estrone & Hormone & 144 & $<0.01$ & 193 & 0.01 & 169 & -29 & ND & ND & 60 & 26.7 & 965 \\
\hline Mestranol & Hormone, EDC & $<1$ & $<0.01$ & $<1$ & $<0.01$ & ND & ND & -- & -- & -- & -- & -- \\
\hline Norethindrone & Hormone, EDC & $<1$ & $<0.01$ & $<1$ & $<0.01$ & ND & ND & -- & -- & 5 & 21 & 1,360 \\
\hline Progesterone & Hormone, EDC & E761 & 0.02 & $\mathrm{E} 1,710$ & 0.05 & 1,236 & -77 & -- & -- & 19 & 143 & 1,290 \\
\hline trans-Diethylstilbestrol ${ }^{6}$ & Hormone, EDC & $<1$ & $<0.01$ & $<1$ & $<0.01$ & ND & ND & -- & -- & -- & -- & -- \\
\hline Testosterone & Hormone & 3.88 & $<0.01$ & 25 & $<0.01$ & 14 & -146 & -- & -- & 17 & 30.8 & 2,040 \\
\hline
\end{tabular}

${ }^{1}$ Wastewater-indicator-method analytes were analyzed by the U.S. Geological Survey National Water Quality Laboratory by pressurized solvent extraction, solid-phase extraction, and gas chromatography/mass spectrometry (Burkhardt and others, 2006).

${ }^{2}$ Information from http://www.endocrinedisruption.com/endocrine.TEDXList.overview.php or http://www.fda.gov/downloads/Drugs/Guidance\%20ComplianceRegulatoryInformation/Guidances/ UCM294086.pdf accessed April 10, 2013.

${ }^{3}$ Pharmaceutical-method analytes were analyzed by the U.S. Geological Survey National Water Quality Laboratory through a research method that involved pressurized solvent extraction followed by high-performance liquid chromotography coupled with electrospray ionization/quadrupole mass spectrometry as described by Kinney and others (2006).

${ }^{4}$ Hormone-method analytes were analyzed by the U.S. Geological Survey National Water Quality Laboratory through a research method that involved pressurized solvent extraction, analyte isolation/ cleanup, and gas chromotography with tandem mass spectrometry as described by Lee and others (2011).

${ }^{5}$ Also analyzed by the Wastewater Indicator laboratory method. Percent content shown is for the concentration determined by using the Wastewater Indicator laboratory method because calculating the percent content for the same analyte using both laboratory methods would bias the percent-content calculations.

${ }^{6}$ Non-steroid, exogenous hormone. 
prevented accurate calculation of analyte recovery. Where the recovery value was lower than the ideal range, the biosolids matrix suppressed recovery of the analyte and the true concentration of that analyte could be larger than reported. Where the recovery value was larger than the ideal range, the biosolids matrix enhanced recovery of the analyte and the true concentration of that analyte could be smaller than reported. Where the recovery value was larger than the ideal range and the concentration in the unspiked sample was large (table 1), concentrations had corresponding large analytical uncertainty that affected the spiked concentration and therefore the calculated recovery (such as for phenol). In general, the quality-control data indicate that the pharmaceutical laboratory method had the most problems from matrix interference, and the hormone laboratory method had the least problems from matrix interference for the Metro District biosolids samples from 2006. Matrix interference affected the quantification of the sample concentration but rarely affected the identification of target analytes. Concentration values that were larger than the MRL and were affected by matrix interference were estimated by the laboratory. Concentration values that were less than the MRL and identified by the laboratory with high confidence also were estimated by the laboratory. These estimated values, along with any other uncensored concentration above zero that was reported by the laboratory, were considered detections for this study. The inclusion of qualified (estimated) values is consistent with the approach used by the U.S. Environmental Protection Agency (EPA) (2009, p. 29-31) for the Targeted National Sewage Sludge Survey, which stated:

When conducting analyses in sewage sludge matrices it is expected that some results will have to be qualified to accurately reflect the uncertainty of the values...EPA encoded the data quality information gathered during the review in the final results database using a series of qualifiers and reasons. EPA did not exclude data unless a result was flawed such that no reasonable use could be made of it...the presence of data qualifiers is not intended to suggest that data are not useable. Rather, the qualifiers are designed to caution the user about an aspect of the data that does not meet the acceptance criteria originally established for the project.

Many OWCs (wastewater indicators, pharmaceuticals, hormones) were detected in the Metro District biosolids samples from 2006 that were analyzed, and many of these compounds were present in the biosolids in substantial concentrations relative to the MRLs and various surface-water concentrations (Kolpin and others, 2002). Thirty-two of all 73 OWCs analytes (43.8 percent) were detected in the September 2006 sample, which was not analyzed for pharmaceuticals. Forty-nine of all 97 analytes (50.5 percent) were detected in the December 2006 sample, which was analyzed for pharmaceuticals. Of the wastewater indicators, 22 of 56 analytes (39.3 percent) were detected in both samples. Detections of wastewater indicators included alkylphenols (such as nonylphenol and octylphenol), alkylphenol ethoxylates, disinfectants (such as phenol and triclosan), fire retardants, fragrances, PAHs (such as fluoranthene and pyrene), sterols, and other wastewater indicators. The December 2006 sample had 13 of 24 pharmaceutical analytes (54.2 percent) detected. Of the hormone-method analytes, 9 of 19 analytes (47.4 percent) were detected in both samples. Relative percent differences (positive or negative) between the two environmental samples were greater than 100 percent for 7 compounds and were greater than 50 percent for 17 compounds (table 1). Relative percent differences (positive or negative) between an environmental sample and the corresponding replicate sample were greater than 100 percent for 3 compounds and were greater than 50 percent for 15 compounds (appendix 2). These data indicate that biosolids samples from the wastewater treatment plant were quite heterogeneous with respect to OWCs concentrations, likely because the biosolids material is physically heterogeneous at the scale that the biosolids were subsampled for most analyses (about $0.5 \mathrm{~g}$ or less). When moist, the biosolids can be seen to contain distinct, megascopic masses of clay and fuzz (clumps of small hairs, natural fibers, synthetic fibers, and other particles) in with the organic matter. Despite this heterogeneity, the biosolids data indicate that pharmaceuticals and steroid hormones composed much less of the total OWCs content than wastewater indicators in these samples collected in 2006. OWCs content of these samples was calculated as the percentage of each analyte concentration relative to the sum of all OWCs concentrations for this study (censored values were treated as zero concentration); many other OWCs (U.S. Environmental Protection Agency, 2009) were not included as analytes in this study because analytical methods were not available at the USGS laboratories. The analytes contributing the largest OWC content were 3-beta coprostanol (about 30 percent of the total OWCs content), 4-nonylphenol (about 21 percent of the total OWCs content), cholesterol (about 16 percent of the total OWCs content), beta-sitosterol (about 10 percent of the total OWCs content), and beta-stigmastanol (about 2-6 percent of the total OWCs content); the remaining OWCs (including all the pharmaceuticals and steroid hormones) collectively composed the other 19 percent of the total OWCs content but individually contributed less than 4 percent of the total OWCs content (table 1). Although only two separate biosolids samples (and associated quality-control samples) were analyzed for OWCs in this study, which is a very small number of samples from a single wastewater treatment plant, these findings are similar to published results from Kinney and others (2006), the EPA (2009), and Lorenzen and others (2004).

Kinney and others (2006) reported a survey of OWCs in various biosolids products. That study determined that 55 of 87 OWCs (63.2 percent) were detected in at least one biosolids product analyzed, and 25 of 87 OWCs ( 28.7 percent) were detected in all nine different types of biosolids products analyzed. These same 25 OWCs also were detected in at least 
one of the Metro District biosolids samples or the replicate, and 21 of these 25 compounds were detected in both of the Metro District biosolids samples and the replicate. The Metro District biosolids are most similar to "biosolid H" from the Kinney and others (2006) study in terms of wastewater processing and product type, and the same five compounds contribute the largest OWC content in both studies. A comparison of the OWC results for the Metro District biosolids with the concentrations reported by Kinney and others (2006, Supplemental information table S1) indicate that many of the concentrations detected with the wastewater indicator laboratory method were one to two orders of magnitude smaller in "biosolid H" (Kinney and others, 2006) than in the Metro District biosolids samples from 2006 (table 1). Concentrations of OWCs resulting from the pharmaceuticals laboratory method were more comparable between the two studies (table 1). "Biosolid H" had a slightly lower steroidhormone content and slightly higher detergent-degradate content than the Metro District biosolids samples analyzed in this study. As with "biosolid H," the Metro District biosolids also had a small proportion of fragrances, fire retardants, disinfectants, PAHs, and pharmaceuticals (including prescription and nonprescription drugs) in the total OWC content compared to the proportion of biogenic sterols in the samples. Some soluble polar compounds (such as pharmaceuticals) were detected in the biosolids samples of both studies, despite having chemical properties that would indicate substantial partitioning to the aqueous treatment stream.

The EPA collected biosolids from 74 American wastewater treatment facilities and analyzed them for a variety of inorganic and organic constituents including wastewater indicators, pharmaceuticals, and steroid hormones; more than one sample was collected from some facilities (U.S. Environmental Protection Agency, 2009). The EPA (2009) reported that fire retardants, fluoranthene, bis(2-ethylhexyl) phthalate (DEHP), polybrominated diphenyl ethers (PBDEs), carbamazepine, diphenhydramine, triclocarbon, ciprofloxacin, beta-stigmastanol, campesterol, cholestanol, and coprostanol were detected (uncensored data, including qualified data) in all or nearly all biosolids samples analyzed. The Metro District biosolids samples collected in 2006 were not analyzed for PBDEs, triclocarbon, ciprofloxacin, campesterol, or cholestanol. Many analytes for the Metro District biosolids samples collected in 2006 were not analytes in the EPA (2009) study, including the detergent degradates (such as nonylphenol and octylphenol), fragrances, and phenol (table 1). Some analytes were common to both studies (table 1). Cotinine, the nicotine degradate, was detected in the Metro District biosolids samples from 2006 but was detected in only 39 of 84 biosolids samples analyzed in the EPA study (table 1). Acetaminophen was detected in the Metro District biosolids samples from 2006 but was detected in only 2 of 84 biosolids samples analyzed in the EPA study (table 1). Many of the concentrations of wastewater indicators in the Metro District biosolids samples were within the range of concentration reported by the EPA (table 1). Some concentrations of OWCs resulting from the pharmaceuticals and hormones laboratory methods were less for the Metro District biosolids samples from 2006 than the minimum concentrations reported for the EPA study. Detected concentrations of cotinine and 17-beta-estradiol were about one order of magnitude less in the Metro District biosolids samples from 2006 than the minimum concentrations reported in the EPA study (table 1). Only one hormone analyte (17-alpha-ethynylestradiol, a synthetic steroid hormone used in oral contraceptives) was not detected in any sample in either the EPA study or in the Metro District biosolids samples from 2006 (table 1).

Lorenzen and others (2004) reported hormone activities in municipal biosolids from Ontario, Canada, and animal manures from various farm animals. This study determined that both estrogen and androgen receptor gene transcription activities were greater in biosolids samples resulting from anaerobic-digestion wastewater treatment than in samples from aerobic digestion. The Metro District biosolids samples from 2006 were a product from anaerobic-digestion wastewater treatment. Although the Metro District biosolids from Denver were not evaluated by the USGS for hormone activities, estrogenic and androgenic hormones and several degradates were detected in both of the biosolids samples from 2006 and the replicate. In addition, nonylphenol and octylphenol compounds were present in the Metro District biosolids samples from 2006 and have some estrogenic activity, although much less than that of steroid hormones (Vajda and others, 2008). Large concentrations of nonylphenol and octylphenol compounds such as were determined for the Metro District biosolids samples from 2006 (table 1) can cause hormone activities that can be comparable to or exceed that from the steroid hormones (Vajda and others, 2008).

\section{Leachates of Biosolids}

Metro District biosolids were leached at various times with reagent-grade water to evaluate mobility of biosolids constituents. These experiments indicate which biosolids constituents are most susceptible to aqueous transport to groundwater or surface water following application.

Yager, Smith, and Crock (2004c) reported results for a leaching experiment of biosolids (samples from 2001) where leachates of fresh, dried biosolids were analyzed for selected inorganic constituents (cations); the resulting data were compared to those from leachates of soil that had not been applied with biosolids. The 2001 leach experiment indicated that a small part of the inorganic constituents within biosolids could be removed by exposure to precipitation or irrigation water over a period of time, with some elements being removed preferentially to others. Antimony, cadmium, cobalt, copper, mercury, molybdenum, nickel, phosphorus, selenium, vanadium, and tungsten had the highest biosolids-leachate to soil-leachate concentration ratios and, therefore, were determined to be useful indicators of biosolids effects on groundwater and surface water (Yager, Smith, and Crock, 2004c). However, both soil from the study area and biosolids 
leach these constituents; the presence of these constituents in groundwater or surface water is not in itself an indication of biosolids effects. The presence of other constituents that are not naturally present in the water of the study area, in addition to elevated or increasing concentrations of these inorganic constituents, would help to identify biosolids effects.

Various samples collected in 2004 and 2005 (including fresh, aged, wet, and dried biosolids) were leached in 2005 (August and December) to evaluate OWC mobility, as well as to verify and expand on results from the 2001 leach experiment for inorganic constituents. In addition to analyses for wastewater indicators and pharmaceuticals, some samples were analyzed for a comprehensive list of inorganic analytes: physical properties, cations (major ions and trace elements), and anions (major ions including nitrate). Results from the leachate experiments indicated that inorganic and organic constituents of biosolids can be mobilized in the presence of water. Major ions, nutrients, and trace elements were detected in the various biosolids leachates from the 2005 experiments. The 2005 leachate experiments confirmed that antimony, cadmium, cobalt, copper, molybdenum, nickel, phosphorus, selenium, vanadium, tungsten, and zinc were still useful inorganic indicators of biosolids effects on water quality, but not enough leachate samples were analyzed for inorganic analytes to enable comparisons about analyte mobility differences for the source materials. However, Yager and McMahon (2012) determined from leachate experiments in 2007 that aluminum, orthophosphate, and uranium concentrations, in addition to specific conductance, can be substantially (4.5 to 181 times) larger in leachates from fresh wet or fresh frozen biosolids compared to leachates from fresh dried biosolids, whereas copper, molybdenum, and sulfate concentrations can be substantially (1.4 to 12.3 times) larger in the leachates from fresh dried biosolids. These leachate data from a limited number and type of biosolids source materials indicate that the form of inorganic constituent (such as oxidized or reduced) in the biosolids at the time of water contact may affect the solubility of at least some of the inorganic constituents. Nitrate also can leach from biosolids, but Yager and McMahon (2012) determined from leach experiments in 2007 that nitrogen in the leachates of fresh dried, fresh frozen (partly thawed), and fresh wet biosolids from the Metro District was primarily in the form of organic or ammonium nitrogen; the ammonium concentration was notably less in the leachate from dried biosolids compared to the leachates from fresh wet or fresh frozen biosolids.

Various OWCs were identified by the laboratory in the biosolids leachates from the 2005 experiments, which included analyses for wastewater indicators and pharmaceuticals. As was the case for the biosolids samples, matrix interference affected the quantification of the sample concentration but rarely affected the identification of target analytes. Concentration values that were larger than the MRL and were affected by matrix interference were estimated by the laboratory. Concentration values that were less than the MRL and identified by the laboratory with high confidence also were estimated by the laboratory. These estimated values, along with any other uncensored concentration above zero that was reported by the laboratory, were considered detections for leachate samples in this study. Detections of OWCs in the Metro District biosolids leachates included detergent degradates (nonylphenol), disinfectants (phenol, triclosan), fire retardants [tris(2-butoxyethyl) phosphate (TBEP)], fragrances [acetophenone, camphor, hexahydrohexamethylcyclopentabenzopyran (HHCB), indole, menthol], pharmaceuticals or their degradates (acetaminophen, carbamazepine, cotinine), plasticizers (DEHP, TBEP), and other wastewater-indicators (benzophenone, p-cresol) (appendix 4). It is noteworthy that some hydrophobic compounds were detected in the leachates considering that these compounds are expected to partition primarily to the clay fraction or organic matter in biosolids and not desorb easily into the aqueous phase. Another noteworthy result of this leachate experiment was that the field-aged biosolids sample leached detectable concentrations of 4-nonylphenol, indole, HHCB, and TBEP despite repeated exposure to precipitation and freeze-thaw cycles during the 8 months following land application before the sample was collected from the field surface. This study did not explore the mechanisms or kinetics of mobility for any of the biosolidsconstituent compounds.

\section{Biosolids Signature}

The concept of a "biosolids signature" as a group of chemical constituents from biosolids that can be used as a marker of biosolids presence or indicator of biosolids effects was presented by Yager, Smith, and Crock (2004c). Since that time, various forms of biosolids samples from the Metro District were analyzed for the first time for nitrogen, anions, and OWCs, were further characterized for metals and other cations, and were leached.

\section{Biosolids Signature for Solid Materials}

The analytical data for biosolids collected during 2004-2010 were used to refine and expand the biosolids signature for soil and streambed sediments in the vicinity of the Deer Trail biosolids-application area that was reported for the 1999-2003 phase of study (Yager, Smith, and Crock, 2004c). Analyses of biosolids samples for inorganic constituents (including nitrogen) and organic constituents (OWCs) from 2004-2010 were used to update the biosolids signature for solid materials.

Data collected during 2004-2010 (Crock, Smith, Yager, Berry, and Adams, 2008, 2009, 2010, 2011; Crock, Smith, Yager, Brown, and Adams, 2008) were used to validate the inorganic-chemical biosolids signature (Yager, Smith, and Crock, 2004c) that can be contrasted with the "natural" geochemical signature for this site. The biosolids signature and an understanding of the geology and hydrology of the site can be used to separate biosolids effects from natural geochemical 
effects for inorganic constituents. Yager, Smith, and Crock (2004c) reported that six regulated elements (cadmium, copper, mercury, molybdenum, selenium, and zinc) were present in substantially higher concentrations in the 19992003 Metro District biosolids than in rock, soil, and streambed sediment near Deer Trail that were not applied with biosolids (hereinafter referred to as "untreated"). Of these elements, copper and mercury had the largest difference in concentration (about two orders of magnitude greater) for 1999-2003 biosolids compared to untreated rock, soil, and streambed sediment near Deer Trail (Yager, Smith, and Crock, 2004c). Of the unregulated elements, Yager, Smith, and Crock (2004c) reported that bismuth and silver had the largest difference in concentration (about two orders of magnitude greater in biosolids). A comparison of the 2004-2010 biosolids-concentration data with the 1999-2003 data for untreated soil, rock, and streambed-sediment data indicates that these relations were still true for the 2004-2010 data. In addition, the 2004-2010 nitrogen and phosphorus data for biosolids indicate at least two orders of magnitude larger concentrations of these elements in biosolids than in untreated rock, soil, and streambed sediment near Deer Trail (Yager and McMahon, 2012; Crock, Smith, Yager, Berry, and Adams, 2008, 2009, 2010, 2011; Crock, Smith, Yager, Brown, and Adams, 2008). Because of their large concentrations in biosolids compared to untreated soils and rocks of the study area (Yager, Smith, and Crock, 2004c), elevated concentrations of bismuth, copper, mercury, nitrogen, phosphorus, and silver, therefore, would be the most likely inorganic biosolids signature to indicate the presence of Metro District biosolids in soil or streambed sediment of the study area (table 2).

The analytical data for biosolids collected during 20042010 also were used to expand the biosolids signature for soil and streambed sediment in the vicinity of the biosolidsapplication area to include a preliminary list of organic chemicals. Only a few Metro District biosolids could be analyzed for OWCs during 2004-2010 (table 1), the pharmaceutical and hormone methods were preliminary at the time of the analyses, and domestic-animal manure, wildlife manure, and untreated soils from the study area were not analyzed for comparison. Compounds that were detected in both of the Metro District biosolids samples and the replicate sample at concentrations much greater than the reporting level might be components of a biosolids signature, especially if those OWCs have only anthropogenic sources. Most of the OWCs analyzed have only anthropogenic sources in the study area; exceptions include biogenic sterols (which appear to occur in much larger concentrations in biosolids than in terrestrial environments from natural sources) and nonsynthetic steroid hormones and their degradates that also can originate from domestic animals and wildlife in the area. Based on the chemical data for the 2006 Metro District biosolids, the presence of biogenic sterols (such as 3-beta-coprostanol and beta-stigmastanol), detergent degradates (such as nonylphenol), disinfectants (such as triclosan), fire retardants (such as TBEP), fragrances (such as AHTN and d-limonene), pharmaceuticals (such as acetaminophen and diphenhydramine), p-cresol, and plasticizers (such as bisphenol A and phthalates), would be the most likely organic-chemical biosolids signature to indicate the presence of biosolids in soil or streambed sediment of the study area (table 2).

The collected data indicate that elevated concentrations of nutrients (nitrogen, phosphorus), trace elements (bismuth, copper, mercury, silver), benzophenone, biogenic sterols (3-beta-coprostanol, beta-sitosterol, beta-stigmastanol, and cholesterol), detergent degradates (nonylphenol and octylphenol), disinfectants (phenol and triclosan), fire retardants (TBEP), fragrances (3-methyl-1H-indole, acetophenone, AHTN, d-limonene, HHCB, and indole), pharmaceuticals (acetaminophen, diphenhydramine, and miconazole), p-cresol, and plasticizers (bisphenol A, DEHP, TBEP) (table 2) would be the most likely biosolids signature to indicate that soil or streambed sediment contain or have been affected by Metro District biosolids. More biosolids-signature components detected and larger concentration difference from untreated materials and quality-control samples indicate more evidence of biosolids presence or effects. Note that wastewatertreatment processes and consumer-product composition, availability, and use and, therefore, the biosolids-product chemical composition can change over time and affect the utility of these components in indicating biosolids presence or effects.

\section{Biosolids Signature for Aqueous Materials}

The 2004-2010 analytical data for filtered biosolids leachates were used to verify and expand the preliminary biosolids signature for aqueous materials (groundwater and surface water) in the vicinity of the Deer Trail biosolidsapplication area that was reported for the 1999-2003 phase of study (Yager, Smith, and Crock, 2004c). Analyses of leachate samples for inorganic constituents (including anions such as nitrate) and organic constituents (OWCs) during 2004-2010 were used to update the biosolids signature for aqueous materials.

Inorganic chemicals that had leachate concentrations from biosolids that were at least two orders of magnitude greater than leachate concentrations from untreated soils during 1999-2010 are molybdenum, nitrogen, phosphorus, and tungsten (Yager, Smith, and Crock, 2004c; Yager and McMahon, 2012). The inorganic biosolids signature is based on data for filtered samples but could apply to unfiltered samples in some cases, such as some groundwater systems. Because of microbiological cycling of nitrogen in the environment, the nitrogen leached from biosolids likely is in an oxygenated form instead of in the reduced form found in fresh biosolids, and oxygenated nitrogen forms resulting from biosolids leachate subsequently could be reduced through denitrification (Yager and McMahon, 2012). Inorganic chemicals that had leachate concentrations about one order of magnitude larger than leachate concentrations from untreated soils during 1999-2010 are antimony, cadmium, cobalt, 
Table 2. Preliminary biosolids signature to indicate presence of biosolids in study-area soil and sediment.

[Biosolids signature derived from analysis of fresh biosolids samples from the Metro Wastewater Reclamation District that had been air dried and ground prior to analysis for inorganic chemicals or that had been stored frozen prior to analysis for organic chemicals. Signature components were at least one order of magnitude larger in concentration in biosolids than in soil (inorganic chemicals) or were at least one order of magnitude larger concentration in biosolids than the reporting level (organic chemicals). All components were checked for recoveries and detection in blanks. Data used to define this signature are included in table 1 or were reported by Yager and others (2004d) or Yager and McMahon (2012). Possible uses or sources information from http://www.mii.org/ commonminerals.html, Tjandraatmadja and others (2010), http://www.epa.gov/hg/mgmt_options.html\#commercial, and Burkhardt and others (2006). $>$, greater than]

\begin{tabular}{|c|c|c|c|}
\hline $\begin{array}{c}\text { Biosolids signature } \\
\text { component for soil and } \\
\text { sediment }\end{array}$ & Description & Possible uses, sources, or sources to biosolids & $\begin{array}{l}\text { Number of } \\
\text { samples } \\
\text { analyzed }\end{array}$ \\
\hline \multicolumn{4}{|c|}{ Inorganic chemicals } \\
\hline Bismuth & Trace element & Cosmetics; pigments; pharmaceuticals & $>100$ \\
\hline Copper & Trace element & $\begin{array}{l}\text { Electrical cables and wires; plumbing; electronics; coins; } \\
\text { jewelry; other consumer products }\end{array}$ & $>100$ \\
\hline Nitrogen & Nutrient & $\begin{array}{l}\text { Human waste; manure; fertilizers; cleaning products personal-care } \\
\text { products; atmospheric deposition; soil minerals }\end{array}$ & 10 \\
\hline Phosphorus & Nutrient & $\begin{array}{l}\text { Human waste; cleaning products; food; inorganic } \\
\text { fertilizer; pesticides; lubricants; plasticisers; soil minerals }\end{array}$ & $>100$ \\
\hline 3-Methyl-1H-indole & Wastewater indicator & Fragrance; stench in feces and coal tar & 3 \\
\hline 4-Nonylphenol (sum of all isomers) & Wastewater indicator & Nonionic detergent degradate & 3 \\
\hline $\begin{array}{l}\text { 4-Nonylphenol diethoxylate, (sum of all } \\
\text { isomers) (NPEO2) }\end{array}$ & Wastewater indicator & Nonionic detergent degradate & 3 \\
\hline $\begin{array}{l}\text { 4-Nonylphenol monoethoxylate, } \\
\text { (sum of all isomers) (NPEO1) }\end{array}$ & Wastewater indicator & Nonionic detergent degradate & 3 \\
\hline 4-tert-Octylphenol & Wastewater indicator & Nonionic detergent degradate & 3 \\
\hline Acetaminophen & Pharmaceutical & Pain killer (pharmaceutical disposal; human excretion) & 2 \\
\hline Acetophenone & Wastewater indicator & Fragrance in detergent and tobacco; flavor in beverages & 3 \\
\hline Cholesterol & Wastewater indicator & Sterol; often a fecal indicator, but also present in plants & 3 \\
\hline Diphenhydramine & Pharmaceutical & Pharmaceutical disposal; human excretion & 2 \\
\hline d-Limonene & Wastewater indicator & Fungicide; antimicrobial; antiviral; fragrance & 3 \\
\hline $\begin{array}{l}\text { Hexahydrohexamethylcyclopenta- } \\
\text { benzopyran (HHCB) }\end{array}$ & Wastewater indicator & Musk fragrance (widespread use) & 3 \\
\hline Indole & Wastewater indicator & Fragrance in coffee; inert ingredient in pesticides & 3 \\
\hline Miconazole & Pharmaceutical & Human excretions and pharmaceutical disposal & 2 \\
\hline p-Cresol & Wastewater indicator & Wood preservative & 3 \\
\hline Phenol & Wastewater indicator & Disinfectant; manufacture of various products & 3 \\
\hline Triclosan & Wastewater indicator & Disinfectant; antimicrobial & 3 \\
\hline Tris(2-butoxyethyl) phosphate (TBEP) & Wastewater indicator & Fire retardant; plasticizer & 3 \\
\hline
\end{tabular}


copper, nickel, selenium, vanadium, and zinc (Yager, Smith, and Crock, 2004c; Yager and McMahon, 2012). Therefore, a likely inorganic biosolids signature that indicates that Metro District biosolids affected water quality of the study area would be elevated concentrations of molybdenum, nitrogen, phosphorus, tungsten, and (to a lesser extent) antimony, cadmium, cobalt, copper, nickel, selenium, vanadium, and zinc in groundwater or surface-water samples (table 3 ).

The 2004-2010 analytical data for leachates of fresh and field-aged biosolids also were used to expand the biosolids signature for groundwater and surface water in the vicinity of the biosolids-application area to include a preliminary list of primarily anthropogenic organic chemicals. Leachates from only a limited number of fresh and field-aged Metro District biosolids samples and one cow-manure sample were analyzed for OWCs during 2004-2010. The pharmaceutical method was under development (preliminary), the hormone method was not available at the time of the analyses, and wildlife manure and untreated soils from the study area were not analyzed for comparison. However, compounds that were detected in the biosolids leachates (fresh, wet; fresh, dried; field aged) at concentrations much greater than the reporting level and that were not detected (or were detected at substantially smaller concentrations) in the equipment-blank samples or the laboratory blanks might be included as components of a biosolids signature, especially if those OWCs have only anthropogenic sources in the study area. As was true for the OWCs in biosolids, most of the OWCs detected in the biosolids leachates have only anthropogenic sources in the study area. Although air-drying the biosolids and preparation of the biosolids leachates in the laboratory environment could have introduced some of the OWCs that were detected in the leachate samples, the OWCs selected for the aqueous biosolids signature were present in the Metro District biosolids samples from 2006 and present in the leachates at concentrations at least two times that of equipment or laboratory blanks. These quality-assurance measures decreased the likelihood of false positives (positive bias in the data) from leachate processing or laboratory contamination. The organic biosolids signature is based on data for filtered samples but could apply to unfiltered samples in some cases, such as groundwater. Organic chemicals that are of particular interest for an aqueous biosolids signature include detergent degradates (such as nonylphenol), disinfectants (such as triclosan), fire retardants (such as TBEP), fragrances (acetophenone and indole), pharmaceuticals or their degradates (such as acetaminophen, carbamazepine, and cotinine), p-cresol, and plasticizers (such as bisphenol A and phthalates), and are included in the preliminary biosolids signature in table 3 . The utility of carbamazepine as a water-soluble molecular marker of sewage in groundwater and surface water also was reported by Nakada and others (2008). The utility of acetaminophen and carbamazepine, as well as pharmaceutical degradates, as chemical markers to differentiate sewage and manure sources of contamination also was reported by Fenech and others (2012). Barnes, Kolpin, Focazio, and others (2008) and Barnes, Kolpin, Furlong, and others (2008) detected concentrations of acetaminophen, acetophenone, bisphenol A, cotinine, p-cresol, triclosan, and TBEP in some groundwater samples collected from sites known or suspected to contain sources of animal or human wastewater, but they did not analyze samples for all of the organic-chemical biosolids-signature components listed in table 3.

The collected data indicate that nutrients (nitrogen, phosphorus), trace elements (antimony, cadmium, cobalt, copper, molybdenum, nickel, selenium, tungsten, vanadium, zinc), benzophenone, detergent degradates (nonylphenol), disinfectants (phenol, triclosan), fire retardants (TBEP), fragrances (3-methyl-1H-indole, acetophenone, camphor, HHCB, indole, menthol), pharmaceuticals or their degradates (acetaminophen, carbamazepine, cotinine), p-cresol, and plasticizers (bisphenol A, DEHP, TBEP), would be the most likely biosolids signature for groundwater and surface water in the study area (table 3). As was true for the solid-materials biosolids signature, more biosolids-signature components detected and larger concentration differences from baseline and blank-sample concentrations indicate more evidence of biosolids presence or effects for groundwater or surface water. Inevitably, consumer-product composition, availability, and use will change over time. These changes in consumer products, as well as changes to treatment processes at the wastewater treatment plant, could change the biosolidsproduct chemical composition and associated leachate composition over time and affect the utility of these components in indicating biosolids presence or effects.

A single sample of cow manure collected from the South-2 site (shown in fig. 2) also was leached and analyzed for OWCs for comparison with the biosolids leachates. Of the analytes included, only isophorone was present in the cow-manure leachate at a concentration substantially larger than the reporting level or blank concentrations and not present in the biosolids leachates. Other OWCs that were present in the cow-manure leachate (as well as in the biosolids leachates) in concentrations substantially larger than the minimum reporting level or blank concentrations include 3-methyl-1H-indole, indole, nonylphenol, p-cresol, and phenol, although the cow-manure sample was not analyzed to verify that the manure was a source of these OWCs. Thus, 3-methyl-1H-indole, indole, isophorone, nonylphenol, p-cresol, and phenol are of interest for a preliminary cow-manure signature. The cow-manure leachate was not analyzed for human pharmaceuticals, veterinary antibiotics, or hormones. It is not known if the single cow-manure sample was representative of beef cattle in the study area or if contamination for OWCs somehow affected the cow-manure sample. Caution should be used in interpreting the results from this single sample. These preliminary data indicate that additional studies would be needed to determine whether these chemicals (3-methyl-1H-indole, indole, isophorone, nonylphenol, p-cresol, and phenol) are representative of cow-manure leachate (table 4 ) or more indicative of biosolids leachate (table 3 ). 
Table 3. Preliminary biosolids signature to indicate the presence of biosolids in groundwater or surface water in the study area.

[Biosolids signature derived from analysis of leachate samples for Metro Wastewater Reclamation District biosolids. All components were checked for detection and magnitude of concentration in biosolids samples. Signature components were either at least one order of magnitude larger concentration in biosolids leachates than in soil leachates or were present in biosolids leachates at concentrations larger than in blank samples or than the minimum reporting level. Leachate data used for this determination are included in appendix 4 (associated quality-assurrance information is included in appendix 5) or were reported by Yager, Smith, and Crock (2004c) or Yager and McMahon (2012). Possible uses, sources, and endocrine-disruptor information from http://www.endocrinedisruption.com/endocrine.TEDXList.overview.php, http://www.mii.org/commonminerals.html, Burkhardt and others (2006), Choe and others (2003), Iavicoli and others (2009), Sikka and Wang (2008), or Tjandraatmadja and others (2010). No analyses for hormones. Detected, uncensored concentration greater than zero reported by the laboratory; >, greater than]

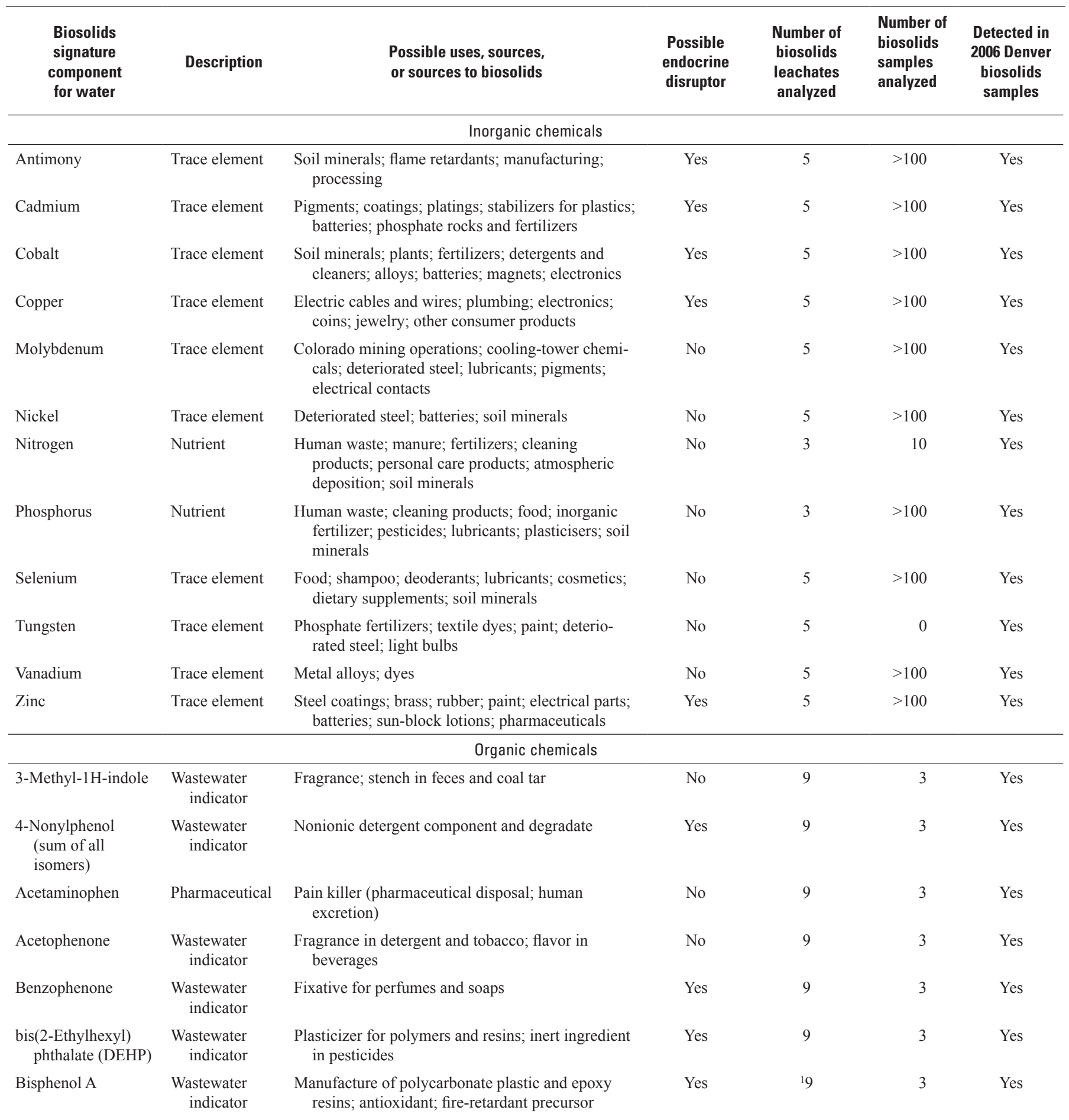


Table 3. Preliminary biosolids signature to indicate the presence of biosolids in groundwater or surface water in the study area.Continued

[Biosolids signature derived from analysis of leachate samples for Metro Wastewater Reclamation District biosolids. All components were checked for detection and magnitude of concentration in biosolids samples. Signature components were either at least one order of magnitude larger concentration in biosolids leachates than in soil leachates or were present in biosolids leachates at concentrations larger than in blank samples or than the minimum reporting level. Leachate data used for this determination are included in appendix 4 (associated quality-assurrance information is included in appendix 5) or were reported by Yager, Smith, and Crock (2004c) or Yager and McMahon (2012). Possible uses, sources, and endocrine-disruptor information from http://www.endocrinedisruption.com/endocrine.TEDXList.overview.php, http://www.mii.org/commonminerals.html, Burkhardt and others (2006), Choe and others (2003), Iavicoli and others (2009), Sikka and Wang (2008), or Tjandraatmadja and others (2010). No analyses for hormones. Detected, uncensored concentration greater than zero reported by the laboratory; $>$, greater than]

\begin{tabular}{|c|c|c|c|c|c|c|}
\hline $\begin{array}{c}\text { Biosolids } \\
\text { signature } \\
\text { component } \\
\text { for water }\end{array}$ & Description & $\begin{array}{l}\text { Possible uses, sources, } \\
\text { or sources to biosolids }\end{array}$ & $\begin{array}{l}\text { Possible } \\
\text { endocrine } \\
\text { disruptor }\end{array}$ & $\begin{array}{l}\text { Number of } \\
\text { biosolids } \\
\text { leachates } \\
\text { analyzed }\end{array}$ & $\begin{array}{l}\text { Number of } \\
\text { biosolids } \\
\text { samples } \\
\text { analyzed }\end{array}$ & $\begin{array}{c}\text { Detected in } \\
2006 \text { Denver } \\
\text { biosolids } \\
\text { samples }\end{array}$ \\
\hline \multicolumn{7}{|c|}{ Organic chemicals-Continued } \\
\hline Camphor & $\begin{array}{r}\text { Wastewater } \\
\text { indicator }\end{array}$ & Flavor; fragrance; odorant; ointments & No & 9 & 0 & $\begin{array}{l}\text { No (no } \\
\text { analysis) }\end{array}$ \\
\hline Cotinine & Pharmaceutical & Primary nicotine degradate & No & 3 & 2 & Yes \\
\hline $\begin{array}{l}\text { Hexahydrohexa- } \\
\text { methylcyclo- } \\
\text { penta- } \\
\text { benzopyran } \\
\text { (HHCB) }\end{array}$ & $\begin{array}{l}\text { Wastewater } \\
\text { indicator }\end{array}$ & Musk fragrance (widespread use) & Yes & 9 & 3 & Yes \\
\hline Menthol & $\begin{array}{l}\text { Wastewater } \\
\text { indicator }\end{array}$ & $\begin{array}{l}\text { Flavor and fragrance, such as in cigarettes, cough } \\
\text { drops, iniment, mouthwash }\end{array}$ & No & 9 & 3 & Yes \\
\hline p-Cresol & $\begin{array}{r}\text { Wastewater } \\
\text { indicator }\end{array}$ & Wood preservative & Yes & 9 & 3 & Yes \\
\hline Phenol & $\begin{array}{r}\text { Wastewater } \\
\text { indicator }\end{array}$ & Disinfectant; manufacture of various products & Yes & 9 & 3 & Yes \\
\hline Triclosan & $\begin{array}{r}\text { Wastewater } \\
\text { indicator }\end{array}$ & Disinfectant; antimicrobial & Yes & 9 & 3 & Yes \\
\hline $\begin{array}{l}\text { Tris(2-butoxyethyl) } \\
\text { phosphate } \\
\text { (TBEP) }\end{array}$ & $\begin{array}{r}\text { Wastewater } \\
\text { indicator }\end{array}$ & Fire retardant; plasticizer & No & 9 & 3 & Yes \\
\hline
\end{tabular}

${ }^{1}$ Detected but not quantified because of poor method performance for this analyte. 
Table 4. Preliminary cow-manure signature to indicate the presence of cow manure in groundwater or surface water.

[Manure signature derived from limited analysis of a single leachate sample for the purpose of comparison with biosolids leachates for the same site. Leachate was prepared using the methods of Hageman (2007) from fresh manure collected from rangeland cattle at site South-2 (shown in fig. 2). Signature components were larger in leachate concentration than in blank or than reporting level. Components were not checked for detection and magnitude of concentration in unleached manure samples. Leachate data used for this determination are included in appendix 4. Possible uses, sources, and endocrine-disruptor information from www.endocrinedisruption.com/endocrine.TEDXList.overview.php or Burkhardt and others (2006). No analyses for veterinary antibiotics, other pharmaceuticals, or hormones. Detected, uncensored concentration greater than zero reported by the laboratory]

\begin{tabular}{|c|c|c|c|c|c|}
\hline $\begin{array}{c}\text { Cow-manure signature } \\
\text { component } \\
\text { for water }\end{array}$ & Description & $\begin{array}{c}\text { Possible uses or sources } \\
\text { other than } \\
\text { cow manure }\end{array}$ & $\begin{array}{l}\text { Possible endocrine } \\
\text { disruptor }\end{array}$ & $\begin{array}{l}\text { Number of manure } \\
\text { leachates analyzed }\end{array}$ & $\begin{array}{c}\text { Detected in Denver } \\
\text { biosolids or biosolids } \\
\text { leachates }\end{array}$ \\
\hline 3-Methyl-1H-indole & Wastewater indicator & $\begin{array}{l}\text { Fragrance; stench in feces } \\
\text { and coal tar }\end{array}$ & No & 1 & Yes \\
\hline $\begin{array}{l}\text { 4-Nonylphenol (sum } \\
\text { of all isomers) }\end{array}$ & Wastewater indicator & Nonionic detergent degradate & Yes & 1 & Yes \\
\hline Indole & Wastewater indicator & $\begin{array}{l}\text { Fragrance in coffee; inert } \\
\text { ingredient in pesticides }\end{array}$ & No & 1 & Yes \\
\hline Isophorone & Wastewater indicator & $\begin{array}{l}\text { Solvent for lacquer, plastic, } \\
\text { oil, silicon, resin, printing } \\
\text { inks }\end{array}$ & No & 1 & No \\
\hline p-Cresol & Wastewater indicator & Wood preservative & Yes & 1 & Yes \\
\hline Phenol & Wastewater indicator & $\begin{array}{l}\text { Disinfectant; manufacture of } \\
\text { various products }\end{array}$ & Yes & 1 & Yes \\
\hline
\end{tabular}

\section{Groundwater}

Applications of pesticides, herbicides, or fertilizers (including biosolids) to the land surface can affect the quality of shallow groundwater directly by contaminated recharge or by infiltration through contaminated soils or sediments (remobilization). These applications also can affect the quality of shallow groundwater indirectly by tilling (which can mobilize subsurface constituents) or by contributions to natural processes such as nitrification. Further, discharge from contaminated alluvial groundwater could contaminate surface water (ponds or streams) or bedrock aquifers. For this report, alluvial groundwater is defined as the water contained in subsurface, unconsolidated (uncemented), wind- or watertransported sediments in current or historical stream channels or flood plains. For this report, bedrock groundwater is defined as the water contained in the fractures or pore spaces of the rock (consolidated sediments) that underlies soil or other uncemented materials; the primary bedrock aquifer in the study area is the Laramie-Fox Hills aquifer (Robson and Banta, 1995). Alluvial and bedrock groundwater are separate components in the monitoring program but are discussed together in this report because the data were collected in the same way, and the types of data included are the same.

\section{Objectives of Monitoring Groundwater}

Groundwater was monitored during 2004-2010 to characterize the hydrology and water quality of the aquifers to (1) determine if concentrations of nitrate, arsenic, cadmium, copper, chromium, lead, mercury, molybdenum, nickel, selenium, and zinc in the groundwater are significantly greater than regulatory standards and (2) determine if concentrations of these constituents are increasing with time in groundwater at or near the Metro District properties. In addition, the groundwater data were evaluated for biosolids effects on groundwater quality using the biosolids signature presented in table 3 .

\section{Approach for Monitoring Groundwater}

Groundwater routinely was monitored for hydrology and chemistry at USGS monitoring wells. Bedrock groundwater routinely was monitored for chemistry at two wells (the shallowest zone of wells DTX8 and DTX10) and for hydrology at five wells (DTX8, DTX10, D11a, D19, and D29) (fig. 2). Alluvial groundwater routinely was monitored for chemistry at five wells (DTX1, DTX2, D6, D17, and D25) and for hydrology at 16 wells (DTX1, DTX2, DTX3, DTX4, DTX5, DTX6, DTX7, DTX9, DTX11, DTX12, D6, D6A, D13, D17, D25, and D25A) (fig. 2). Vertical recharge was evaluated at two recharge-evaluation areas (DTX8 and DTX10) by using water-level data from wells at various depths at the same site in conjunction with precipitation data. Comparisons of water-level altitudes were based on high-resolution survey data for the recharge-evaluation-area wells measured by the USGS in 1999. Continuous recorders with electronic data logger equipment (EDL) or data-collection platforms (DCPs) provided detailed hydrologic information for six sites (DTX2, DTX5, DTX9, DTX10, DTX11, and D25) at various times during 2004-2010; however, the instrumentation at DTX2, DTX5, and D25 was removed early in the 2004-2010 period. Detailed information about site selection, well completion, lithology, data-collection methods, and quality assurance are provided by Yager, Smith, and Crock $(2009,2011,2012)$. 
Monitoring wells for the expanded monitoring program included selected wells installed as part of the previous USGS monitoring programs in the study area and one new well (DTX12) that was installed in 2009 as a replacement for a damaged well (D30) in the same location. Of the 33 USGS groundwater monitoring wells from the initial 1993-1999 study on the Metro District Central property, 9 wells were included in this study ( 9 wells routinely were measured for depth to water, and 3 wells routinely were sampled for water quality). Of the 11 USGS groundwater monitoring wells from the expanded 1999-2003 study in the study area, all 11 wells were included in this study (11 wells routinely were monitored for hydrology including depth to water, and 2 wells routinely were sampled for water quality). The newest monitoring wells were installed in the study area in 1999, 2000, 2002, and 2009. "D"-numbered wells were drilled before 1999 as part of the initial monitoring program (except for wells D6A and D25A), and "DTX"-numbered wells were drilled between 1999 and 2009 (fig. 2).

Water levels (depth to groundwater) were measured monthly at the USGS monitoring wells in the study area, as well as continuously at several sites, to provide a hydrologic context for water-quality monitoring during 2004-2010. DCPs with various sensors operated at various times during 2004-2010 at wells D25, DTX2, and DTX5 to continuously measure water levels, water temperature, precipitation, and air temperature. Water levels, precipitation, and sometimes air temperature were continuously measured at one rechargeevaluation area (DTX9/DTX10/DTX11) by EDL or DCP during 2004-2010. The data provided information about the hydrology in the study area and about the response of groundwater to climatic variables.

Water samples usually were collected quarterly from five alluvial-aquifer wells on the Metro District properties, and water samples were collected annually from the shallowest zone (A) of the bedrock aquifer at two locations (DTX8 and DTX10) that are important to alluvial/bedrock groundwater interactions, the recharge-evaluation areas. During most of the monitoring program, the remaining USGS monitoring wells were used to provide hydrologic information only; however, a one-time sampling of all USGS monitoring wells in the study area that were in good condition was done in 20072008 (the resulting data were reported by Yager, Smith, and Crock, 2011). During 2004-2010, groundwater samples were collected using standard USGS clean-hands protocols (U.S. Geological Survey, variously dated), which were summarized by Stevens and others (2003). Groundwater samples were analyzed for many parameters, including the priority parameters identified by the stakeholders (nitrate, arsenic, cadmium, copper, chromium, lead, mercury, molybdenum, nickel, selenium, and zinc). Plutonium isotopes, gross alpha, and gross beta were not considered during this phase of study because plutonium isotopes were not detected in any of the 1999-2003 biosolids samples (Yager, Smith, and Crock, 2004c). Groundwater samples were analyzed routinely for physical properties, dissolved major ions, dissolved and total nutrients, and dissolved trace elements by the USGS using methods described by Yager, Smith, and Crock (2009, 2011, 2012). Groundwater samples from the five routinely sampled alluvial-aquifer wells also were analyzed for dissolved OWCs (wastewater indicators, only) once in 2005. Wastewater indicators were analyzed by the USGS using polystyrenedivinylbenzene solid-phase extraction and capillary-column gas chromatography/mass spectrometry (detailed by Zaugg, Smith, and Schroeder, 2006). Because mass spectrometry is an "information-rich" method, analytes in leachate samples that were positively identified below the MRL and met other quality-control criteria were reported as estimated concentrations (Childress and others, 1999; Rounds and others, 2009; Zaugg, Smith, and Schroeder, 2006). The pharmaceutical and hormone methods were not available at the time the groundwater samples were collected for OWC analysis. Water levels and field measurements such as $\mathrm{pH}$ and specific conductance were recorded with the collection of each groundwater sample. Blank and replicate samples were analyzed to evaluate bias and variability of the groundwater data. In addition, a matrix spike was prepared from a replicate groundwater sample in 2005 to evaluate the OWCs method performance for a representative groundwater matrix. The OWC data for the groundwater samples that are included in this report are presented as received from the laboratory. All groundwater data are maintained in the USGS National Water Information System (NWIS) database (http://waterdata.usgs.gov/nwis).

\section{Hydrology}

The primary water-supply aquifer in the study area is the Laramie-Fox Hills aquifer, which is a bedrock aquifer that ranges from 0 to about $200 \mathrm{ft}$ thick in the study area and is the bottom aquifer in the Denver Basin aquifer sequence (Robson and others, 1981; Robson and Banta, 1995). The general direction of groundwater flow in the bedrock aquifer was from south to north with a component of flow to the east (Yager and Arnold, 2003). Multiple alluvial aquifers are present in the study area. These aquifers are associated with the surficial drainage network and contain water of variable quality, are of limited extent, and generally yield little water (Stevens and others, 2003; Yager and Arnold, 2003; Yager, Smith, and Crock, 2004a, 2004b, 2004c; Yager, Smith, Crock, and Stevens, 2004). A component of groundwater flow in the shallow aquifers was down valleys; well coverage was not sufficient to determine if another component of flow was perpendicular to the valley floor down hill slopes (Yager and Arnold, 2003). Water-table gradients generally were local.

The study area is within the South Platte River drainage basin; all streams in the study area flow into the South Platte River (U.S. Geological Survey, 1974). Short segments of some of the streams are intermittent, but in general, the streams are ephemeral and flow only after storms. In general, the streams of the study area lose water to groundwater when they flow. Muddy Creek, a stream on the western side of the study area, 
is hydraulically connected to the water table in both the alluvial and bedrock aquifers (Yager and Arnold, 2003). Beaver Creek, a stream in the southeastern part of the study area, also is hydraulically connected to the water table but only in the alluvial aquifer; no bedrock aquifer is present in that part of the study area (Yager and Arnold, 2003). Badger Creek, a stream in the northern part of the study area, is hydraulically connected to the water table in at least the alluvial aquifer in the vicinity of wells DTX1 and DTX2 (fig. 2). Hydraulic characteristics of Cottonwood and Rattlesnake Creeks on the Metro District properties are variable; lower reaches of the streams on the Metro District properties are hydraulically connected to the water table in alluvial aquifers, but upper reaches are disconnected from the water table (Yager and Arnold, 2003).

\section{Water Levels}

Groundwater levels fluctuated spatially and temporally during 2004-2010 (fig. 5). Water levels that were below the screened interval (DTX3 and DTX4, fig. 5) were measured in the sump water and, therefore, represent times when the well was considered "dry." Water levels in figure 5 are shown as measured in depth to water below measuring point (instead of depth to water below land surface) to preserve the precision in the depth measurements. Depth to water below land surface is approximately the depth to water below measuring point minus the amount of well casing that sticks up above the land surface. Land-surface altitude is not a constant but fluctuates in this study area because of local erosion and deposition, so water levels that are reported as depth below land surface are reported with less precision. Depth to water below land surface in the bedrock-aquifer monitoring wells ranged from about $2.1 \mathrm{ft}$ (April 2010 at DTX8B) to about $152 \mathrm{ft}$ (June 2005 at D29) (Yager, Smith, and Crock, 2009, 2012). Depth to water below land surface in the alluvial-aquifer monitoring wells ranged from about $3.5 \mathrm{ft}$ (January 2004 at DTX2, August 2008 at D23) to about $21 \mathrm{ft}$ (May 2006 at DTX6) (Yager, Smith, and Crock, 2009, 2011, 2012). Water levels fluctuated over time the least at wells DTX8B $(0.70 \mathrm{ft})$, DTX10B $(0.93 \mathrm{ft})$, D11a $(1.56 \mathrm{ft})$, and D29 (0.92 ft). Water levels fluctuated over time the most at wells DTX4 (7.86 ft) and DTX5 (9.76 ft) where an unusually large amount of rain during the summer of 2006 was followed by an unusually large amount of snow in early 2007 and more rain again early in the summer of 2007. Water levels fluctuated the least during winter and the most during summer. At some wells, these fluctuations are present in a distinct seasonal pattern. Seasonal water-level declines and rises are evident at some wells where the aquifers had shallow groundwater (DTX1, DTX2, DTX7, DTX8A, DTX12, and D13; fig. 5). Seasonal water-level declines indicate periods where evapotranspiration exceeded groundwater recharge (Yager and Arnold, 2003). Seasonal water-level increases indicate periods where recharge exceeded evapotranspiration.
The water-level data indicate that groundwater levels generally increased or stayed nearly constant at most monitoring wells but declined for at least some extended period during 2004-2010 at five wells (fig. 5). A general increase in water level is evident in the 2004-2010 data for wells DTX6, DTX7, D6, D6A, and D13. Water levels stayed fairly constant throughout 2004-2010 at wells DTX1, DTX3, DTX8B, DTX9, DTX10 (A and B), DTX11, D17, D25, D25A, and D29. Water levels in the alluvial aquifer in Badger Creek at well DTX2 declined about 3 feet per year (ft/yr) during 20042006 then increased during 2007-2010. Water levels in the alluvial aquifer in Middlemist Creek at well DTX3 decreased during 2004 until the well was dry (during 2005-2010, except for a period of recharge in 2006). Water levels in the alluvial aquifer in the eastern Beaver Creek tributary at well DTX4 rose in May 2006 to the peak in June 2007 then declined about $4 \mathrm{ft} / \mathrm{yr}$ through June 2009. Water levels in the alluvial aquifer at well DTX5 declined about $0.8 \mathrm{ft} / \mathrm{yr}$ from 2004 to May 2006, rose in May 2006 to the measured peak in June 2007, then declined about $2.3 \mathrm{ft} / \mathrm{yr}$ from June 2007 to July 2010. Water levels in the bedrock aquifer at well D11a declined slightly (less than $0.5 \mathrm{ft} / \mathrm{yr}$ ) during 2004-2010. Despite periods of declining water levels in many of the monitoring wells, only wells DTX3 and DTX4 were dry or nearly dry during 2004-2010, as evidenced by the distance of the water level relative to the bottom of the screened interval (fig. 5). Monitoring wells that had increasing water levels after 2006 likely received recharge from a large winter snow accumulation in early 2007 and possibly from mid-year rains (wells DTX2, DTX4, DTX5, DTX6, DTX7, DTX8A, DTX9, DTX10A, DTX11, D6, D6A, and D13). The water levels in some wells (wells DTX3, DTX4, DTX5, D25, and D25A) were more affected by a mid-year rain in 2006 than the winter snow accumulation in early 2007.

The reasons that water levels in some wells declined while water levels in other wells in the study area increased or stayed the same during 2004-2010 relate to localized precipitation patterns, topographic variation, aquifer properties, and anthropogenic activities. Intense rain is more likely to run off quickly than to infiltrate to groundwater, so locations where runoff travels more slowly or collects in ponds are more likely to have recharge to groundwater. In addition, thin aquifers of small areal extent usually are more vulnerable to depletion during dry periods and can equilibrate slowly after recharge if confined (DTX4 and DTX5). Although groundwater from the monitoring wells is not pumped for agricultural or other use, a supply well upstream from well DTX3 in Middlemist Creek (likely completed in the same aquifer as well DTX3) was pumped since 1999 (perhaps about 5 acre-feet per year [acre-ft/yr], according to Mitch Costanzo, Metro Wastewater Reclamation District, written commun., January 15,2004$)$ and likely intercepts the groundwater that normally would flow to the DTX3 location. 

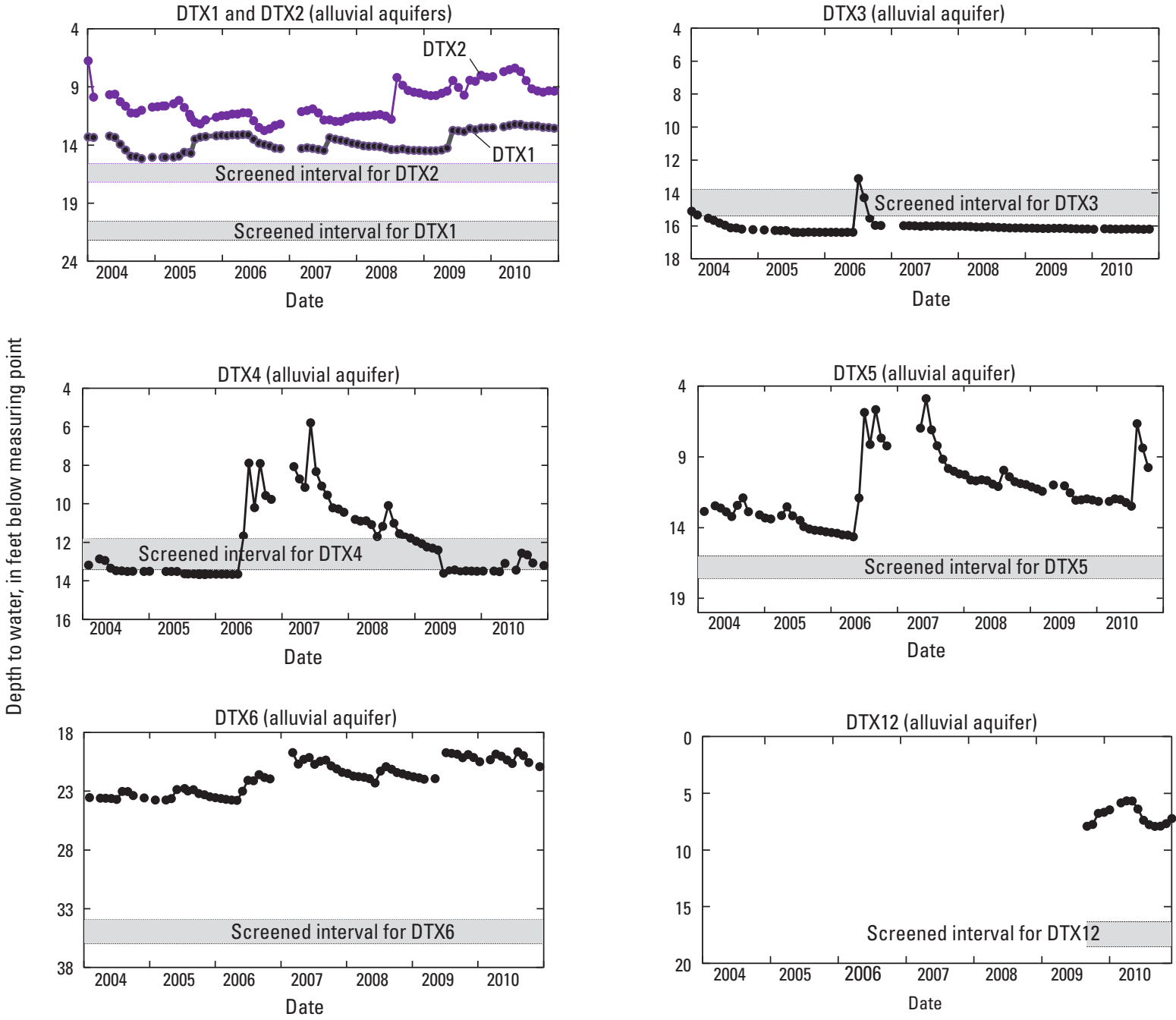

Figure 5. Graphs showing monthly water-level data for selected U.S. Geological Survey monitoring wells near Deer Trail, Colorado, 2004-2010. 

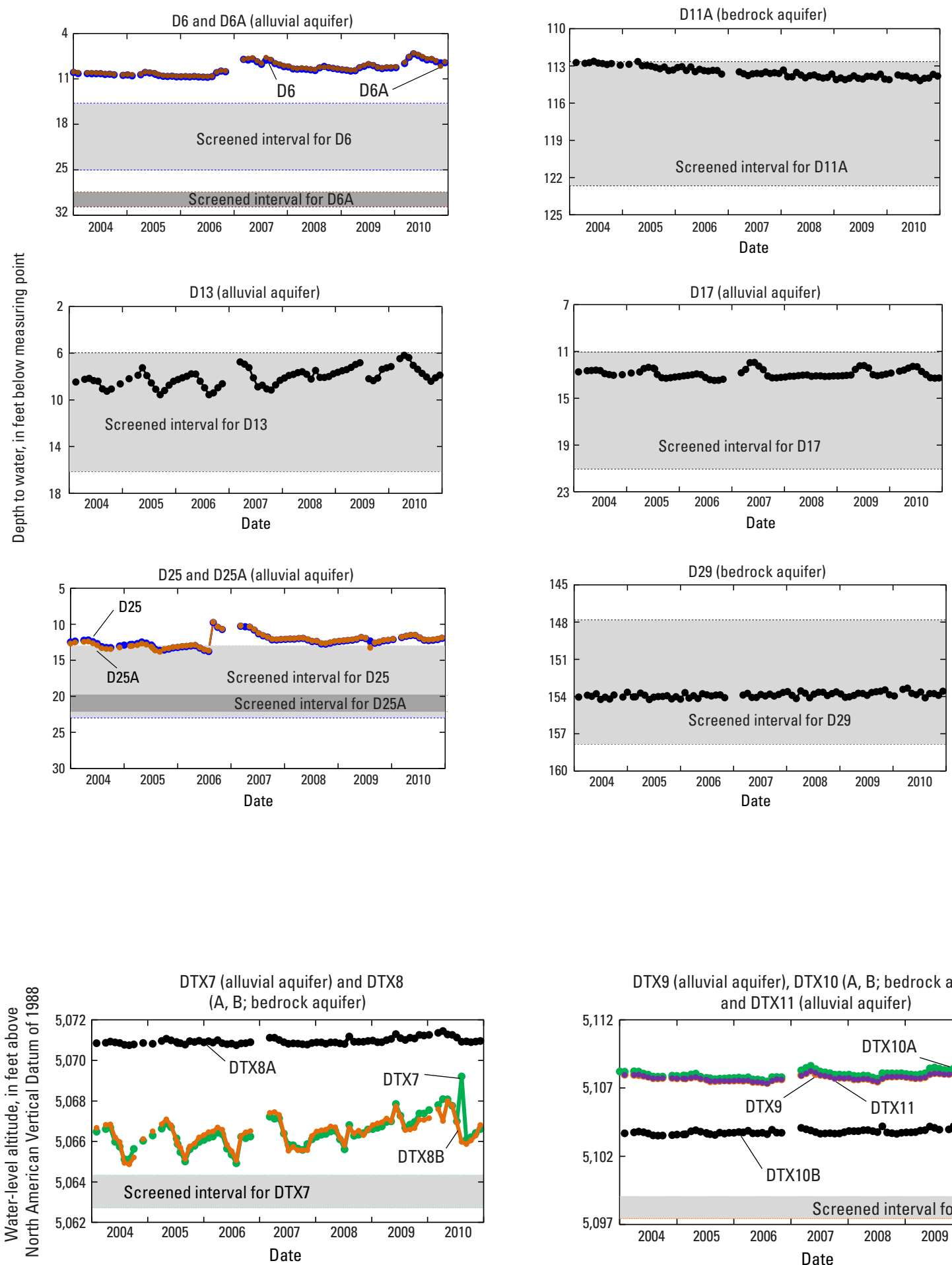

DTX9 (alluvial aquifer), DTX10 (A, B; bedrock aquifer), and DTX11 (alluvial aquifer)

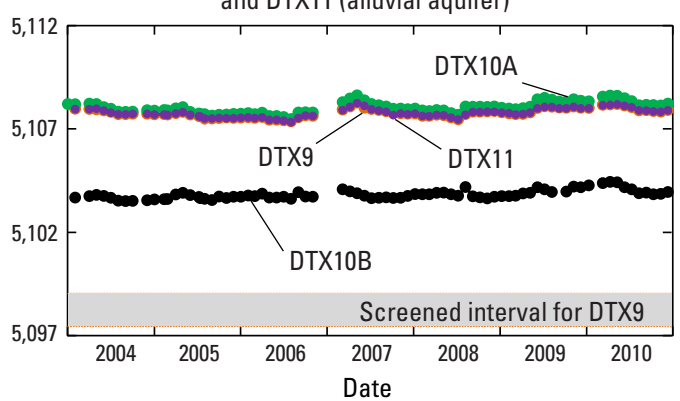

Figure 5. Graphs showing monthly water-level data for selected U.S. Geological Survey monitoring wells near Deer Trail, Colorado, 2004-2010.-Continued 


\section{Recharge}

Several mechanisms recharge groundwater in the study area. Precipitation can directly recharge groundwater by percolation through porous rock outcrops or through the unsaturated zone. Precipitation can indirectly recharge groundwater by producing streamflow or pond water that infiltrates. In a sense, groundwater flow within the same aquifer (throughflow) can be a form of recharge in that any discrete parcel of water has traveled from someplace else to that location. Groundwater in one aquifer also can recharge groundwater in a different, hydraulically connected aquifer (such as an alluvial aquifer recharging the bedrock aquifer, or the reverse) (Yager and Arnold, 2003). Age-dating of groundwater at selected sites in the study area in 1998 indicated that the groundwater recharged too slowly at wells D13 and D17 at that time to show effects from biosolids applications during 2004-2010, but recharge ages were inconclusive for wells D6 and D25 because old and young groundwater were mixing at well D6, and a different test was needed to confirm the age of groundwater from well D25 because of methane concentrations (Yager and Arnold, 2003, table 3). Natural or anthropogenic changes to the fields, especially those that result in soil or streambed sediment deposition, or erosion, desiccation, or compaction around the monitoring wells, can affect the recharge rate for the shallow monitoring wells over time. Therefore, the specific recharge dates calculated from the 1998 data for the groundwater at the METROGRO Farm may now be invalid.

Another way to evaluate groundwater recharge is through comparison of precipitation data with groundwater-level data. Increased water levels are considered a sign of groundwater recharge. Data indicate that wells DTX1, DTX2, DTX4, DTX5, DTX6, DTX7, DTX8A, DTX9, DTX10A, D6, D6A, $\mathrm{D} 13, \mathrm{D} 25$, and $\mathrm{D} 25 \mathrm{~A}$ respond to certain precipitation rates and quantities by rapidly increased water levels (Yager, Smith, and Crock, 2004c; fig. 5). The increased water levels could mean that precipitation infiltrates at the well, or that precipitation infiltrates elsewhere and causes corresponding increased groundwater pressure at the well, which results in increased water levels at the well. Yager and Arnold (2003) reported that age-dating of groundwater samples from wells D6 and D25 in 1998 indicated that groundwater at those sites likely was much older than indicated by the quick water-level response to precipitation, so the quick water-level response to precipitation at some sites could underestimate the travel time of chemical constituents or contaminants vertically down through the unsaturated zone above the aquifers or even

horizontally through the aquifer.

Continuous-recorder data for water levels and precipitation provided detailed recharge information for 2004-2010 at one location in the study area (fig. 6). These data indicate that episodic recharge from precipitation sometimes affected groundwater levels. At wells DTX9, DTX10A, and DTX11, episodic recharge from late-summer rain increased the water level a maximum of about $0.7 \mathrm{ft}$ in 2008 (fig. 6). The precipitation data do not indicate the large accumulation of snow at this site in early 2007 because the type of rain gage that was in use under-reports snowfall, especially in the presence of wind (unpub. data on file at U.S. Geological Survey, Colorado Water Science Center). However, melting of snow accumulated from that time resulted in the large recharge peaks indicated by water levels at wells DTX9, DTX10A, and DTX11. This episodic recharge at the continuous-recorder site was followed by a higher rate of water-level decline than during other periods of declining water levels. One reason for the increased rate of decline can be that higher water levels mean the groundwater is closer to the land surface (for the shallowest aquifer) and, therefore, more subject to evapotranspiration. A more likely reason for the increased rate of decline is that episodic groundwater recharge in the study area usually is localized; the aquifers recharge more and faster in selected areas in response to precipitation infiltration, but then the subsequent equilibration of hydraulic head in the aquifer can cause localized water-level declines in addition to the normal declines from evapotranspiration. The continuous-recorder data indicate that groundwater was not recharged from every precipitation event. During short periods of intense rainfall (such as the 0.6 inch of rain that fell within $1 \mathrm{hr}$ in July 2006 and August 2009, the 0.7 inch of rain that fell within $1 \mathrm{hr}$ in June 2008, and the 0.8 inch of rain that fell within $1 \mathrm{hr}$ in August of 2006), more precipitation flows over the land surface (overland flow, runoff) than infiltrates to recharge groundwater (unpub. data on file at U.S. Geological Survey, Colorado Water Science Center). Patterns of small-quantity, low-intensity precipitation resulted in no apparent recharge in groundwater (fig. 6), likely because any precipitation that infiltrated was not transported throughout the unsaturated zone to the aquifer or because the recharge was less than the evapotranspiration for that day.

Groundwater recharge in the study area also was evaluated in more detail by comparing data for multiple aquifers and multiple zones within aquifers at the same location. Multiple wells in the same location enable different zones of groundwater to be monitored without having to consider spatial variability and can enable inferences about vertical directions of groundwater flow between zones. Two recharge-evaluation areas were monitored: one containing wells DTX7 and DTX8, and one containing wells DTX9, DTX10, and DTX11 (fig. 2). Wells DTX7, DTX9, and DTX11 are alluvial-aquifer wells. Wells DTX8 and DTX10 are bedrock-aquifer wells. Each of these two bedrock-aquifer wells are nested, which means each borehole has two separate piezometers screened at two separate zones (zones A and B, with zone A representing the shallower zone). Therefore, at least three different aquifer zones are monitored at each of the two recharge-evaluation areas in Muddy Creek downgradient from the Metro District properties (fig. 2). Equipment was installed to continuously monitor precipitation and water levels in wells DTX9, DTX10 (zone A), and DTX11 and to provide more detailed information about groundwater recharge at those locations. 


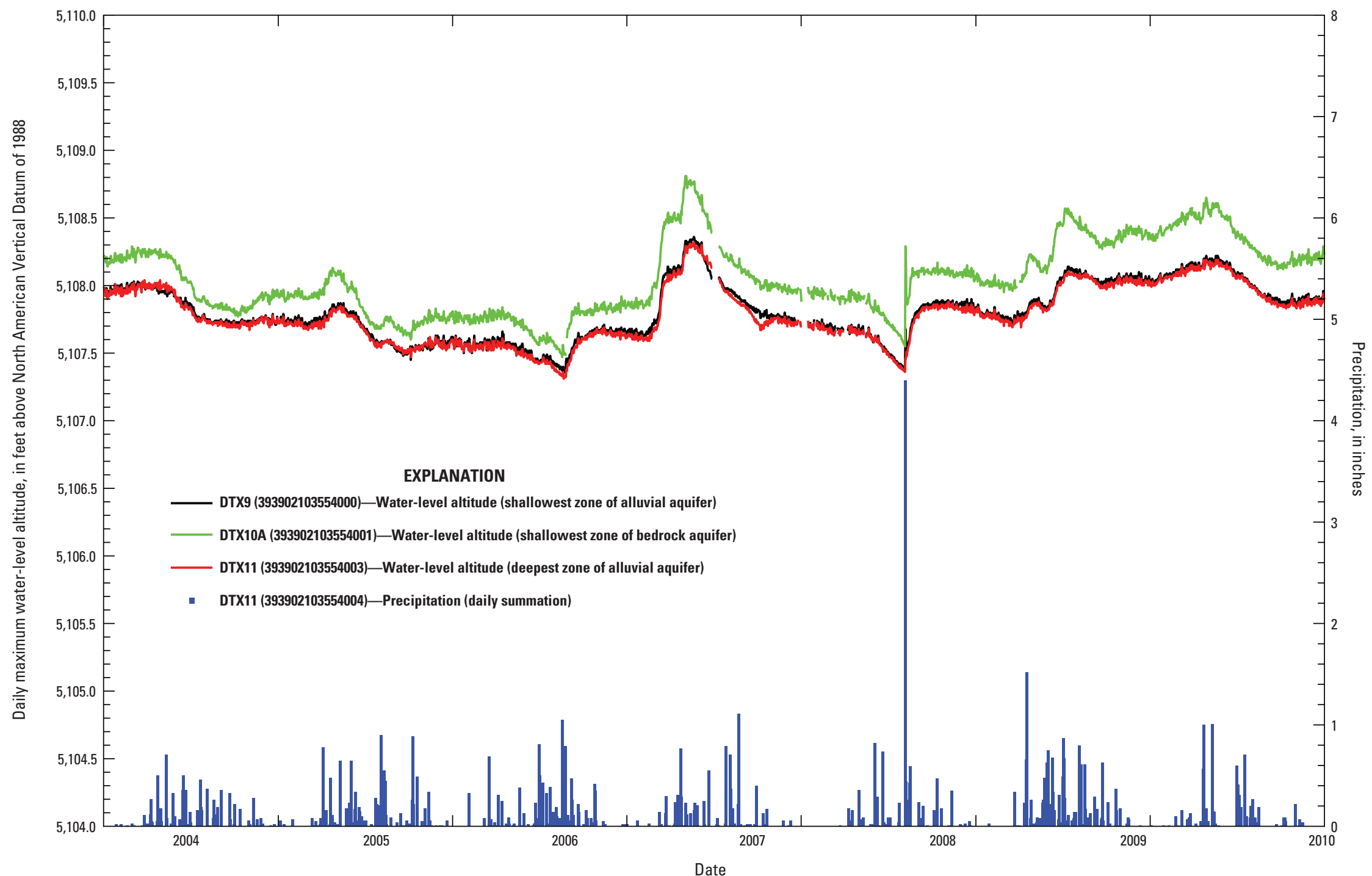

Figure 6. Graphs showing continuous water-level altitudes for wells DTX9, DTX10, and DTX11, and precipitation data for the recharge-evaluation area near Deer Trail, Colorado, 2004-2010. 
The public was concerned that biosolids applications could contaminate alluvial aquifers, which then would contaminate the bedrock aquifer. The USGS studies near Deer Trail indicate that in the study area, the alluvial aquifers generally are hydraulically connected to surface water and may be susceptible to surficial contamination (Yager and Arnold, 2003). The sandy, shallow part (the Fox Hills Formation) of the Laramie-Fox Hills bedrock aquifer in the study area is used for domestic water supply. This shallow zone of the bedrock aquifer (represented by zone A of DTX8 and DTX10 and therefore designated DTX8A and DTX10A) is hydraulically connected to the alluvial aquifer where both are present in the study area at wells D25, DTX7, and DTX9/ DTX10. The deeper zone of the Laramie-Fox Hills bedrock aquifer (represented by zone B of DTX8 and DTX10 and therefore designated DTX8B and DTX10B) is the transition zone to the Pierre Shale and is characterized by interbedded siltstone, sandstone, and shale that is permeable but has low hydraulic conductivity. The deeper zone (B) of the bedrock aquifer contains water but is essentially hydraulically disconnected from the stream, the alluvial aquifer, and the shallow zone (A) of this same bedrock aquifer. Water-level data for 2004-2010 from the recharge-evaluation areas can be used to assess vertical hydraulic gradients, which provide information about the possible flow direction for groundwater contaminants at those locations.

During 2004-2010 at the recharge-evaluation area that is closest to the biosolids-application area, water-level altitudes of the shallow bedrock-aquifer zone (DTX10A) nearly always were slightly higher than those of both zones of the overlying alluvial aquifer (DTX9 and DTX11) (figs. 5 and 6), which always were much higher than the water-level altitudes of the deep bedrock-aquifer zone (DTX10B) (fig. 5). Water-level altitudes of the shallow alluvial-aquifer zone (DTX9) usually were the same (within measurement uncertainty) as the waterlevel altitudes of the deep alluvial-aquifer zone (DTX11) (figs. 5 and 6). These data indicate a slight upward hydraulic gradient between the shallow bedrock-aquifer zone (DTX10A) and either zone of the alluvial aquifer, and a downward hydraulic gradient between the shallow (DTX10A) and deep (DTX10B) bedrock-aquifer zones. Thus, the vertical hydraulic gradient was nearly always favorable for the shallow, sandy zone of the bedrock aquifer to recharge (discharge to) the alluvial aquifer and the deeper zone of the bedrock aquifer. Exceptions indicated by hourly data (unpub. data on file at U.S. Geological Survey, Colorado Water Science Center) were August 6 and 7,2008, when the minimum annual water level for the shallow zone of the bedrock aquifer (DTX10A) occurred at the same time as the summer recharge (water-level rise) in either zone of the alluvial aquifer (DTX9 or DTX11). At these times, the vertical gradients were approximately flat (the vertical hydraulic gradient was less than measurement uncertainty). The vertical hydraulic gradient could have reversed briefly on October 4 and 6, 2005, and August 27, 2006, but that is not known because equipment malfunctioned and did not record data at those times. Therefore, the shallow zone of the bedrock aquifer at this location was not very susceptible to surficial contamination, such as that from biosolids applications or animal manure. Hydrogeologic sections (Yager and Arnold, 2003) and water-level data (Yager, Smith, and Crock, 2009, 2011, 2012) indicate that this generally upward hydraulic gradient may apply throughout much of the Muddy Creek floodplain between D11a and the DTX9/ DTX10/DTX11 area. Although the vertical hydraulic gradients were favorable for flow from the shallow to the deep zones of the bedrock aquifer at this recharge-evaluation area, the deep zone of the bedrock aquifer was unlikely to be contaminated by the downward hydraulic gradient because the shallow zone of the bedrock aquifer did not have favorable hydraulic gradients for contamination from surficial sources at this location. Moreover, lithologic information for this location reported by Yager and Arnold (2003) indicate that horizontal flow gradients could greatly exceed the vertical flow gradients between the zones of the bedrock aquifer in this area.

Conversely, data for 2004-2010 from the rechargeevaluation area that is farther downstream and downgradient from the biosolids-application area (DTX7/DTX8) indicate that the vertical hydraulic gradient was sometimes favorable for the shallow zone of the bedrock aquifer to recharge the alluvial aquifer and sometimes favorable for the alluvial aquifer to recharge the shallow zone of the bedrock aquifer. During most of 2004 through mid-2009, the water-level altitudes of the shallow bedrock-aquifer zone (DTX8A) were higher than those of the alluvial aquifer (DTX7) (fig. 5). During mid-2009 through 2010, the water-level altitudes of the shallow bedrock-aquifer zone (DTX8A) usually were lower than those of the alluvial aquifer (DTX7) (fig. 5). Water-level altitudes of the deep bedrock-aquifer zone (DTX8B) were always much higher than those of the overlying alluvial aquifer (DTX7) and those of the shallow bedrock-aquifer zone (DTX8A) (fig. 5). These data indicate, a slight upward hydraulic gradient between the shallow bedrock-aquifer zone (DTX8A) and the overlying alluvial aquifer (DTX7) during most of 2004 through mid-2009, a downward hydraulic gradient between the alluvial aquifer (DTX7) and the shallow bedrock-aquifer zone (DTX8A) intermittently during 2004 through mid-2009 and during most of mid-2009 through 2010, and an upward hydraulic gradient between the deep (DTX8B) and shallow (DTX8A) bedrockaquifer zones during 2004-2010. The vertical hydraulic gradients were favorable for the shallow and deep zones of the bedrock aquifer to recharge the alluvial aquifer during much of 2004-2010, and contamination of the bedrock aquifer from the alluvial aquifer at the DTX7/DTX8 location was unlikely at these times. During some extended period of most years (usually mid-summer through fall and during most of 2010) but not at all during 2006, the vertical hydraulic gradients were favorable for the alluvial aquifer to recharge the shallow bedrock-aquifer zone. Thus, the shallow zone of the bedrock aquifer at the DTX7/DTX8 location was much more susceptible to surficial contamination, such as that from biosolids applications or animal manure. Wildlife or 
domestic-animal manure, domestic sewage, farming chemicals, or even biosolids-tainted surface water could contaminate the aquifers at the DTX7/DTX8 location during the periods when the vertical hydraulic gradient is favorable. The land uses in close proximity to this recharge-evaluation area containing DTX7/DTX8, however, are likely to have a larger effect on groundwater quality than the biosolids applications that are more than 4 mi upstream. This is especially true given that the vertical hydraulic gradient rarely was favorable for surficial contamination to affect the aquifers in at least one location (DTX9/DTX10/DTX11) between the northern rechargeevaluation area and the biosolids-application area during 2004-2010.

The recharge information discussed above for 2004-2010 may not apply to later periods. Groundwater withdrawals from pumping the aquifers in the study area could completely change these gradients either temporarily or permanently. The amount, timing, and duration of precipitation could change the apparent vertical hydraulic gradients, especially if the hydraulic connection decreases between the stream and the alluvial aquifer, or between the alluvial aquifer and the shallower zone of the bedrock aquifer.

\section{Effects of Biosolids on Groundwater Quality}

This expanded monitoring program directly considered only the chemical effects of biosolids on groundwater quality of the study area; the effects of biosolids on groundwater are expected to be mostly microbiological or chemical in nature. The chemical effects of biosolids on groundwater quality could be inorganic (nutrients and trace elements) or organic (natural and synthetic carbon compounds, including OWCs). The priority parameters for groundwater identified by the stakeholders included the nine trace elements regulated for biosolids along with nitrate and chromium; however, most of the priority parameters are part of natural aquifer geochemical composition and variation. In order to state with confidence that groundwater composition for the priority parameters is affected by biosolids, the groundwater composition or variation must significantly exceed the natural aquifer geochemical composition and variation.

How can natural aquifer geochemical composition and variation be determined for the study area when only one of the wells in this monitoring program (D6) was installed before biosolids applications in the study area began in late 1993 ? Wells upgradient from the biosolids-application property were not a viable approach to establish natural aquifer geochemical composition and variation for the priority parameters because the pre-biosolids sampling at 10 monitoring wells on the Metro District Central property in 1993 indicated a substantial range in concentration of nutrients and trace elements over short distances (U.S. Geological Survey, unpub. data on file at U.S. Geological Survey Colorado Water Science Center, 2011), and the priority parameters are not conservative along groundwater flow paths. Concentrations of most of these parameters increase and decrease naturally in the groundwater because of dissolution and precipitation of minerals, chemical reactions, and microbiological transformations, and by inputs from sources that may include but are not limited to biosolids. Inverse geochemical modeling for the 1993-1999 phase of monitoring indicated that multiple natural processes, as well as biosolids applications, could produce the concentrations found in the groundwater samples (U.S. Geological Survey, unpub. information on file at U.S. Geological Survey Colorado Water Science Center, 2011). Therefore, multiple approaches were used to discern possible biosolids effects on groundwater quality in the study area.

\section{Summary of Water Quality}

A summary of groundwater-quality data for all sites and all constituents and characteristics monitored during 2004-2010 is included in table 5. Groundwater quality was evaluated by sampling different sites at the same time and by sampling the same sites at different times. Groundwaterchemical data for 2004-2010 were reported for all inorganic constituents by Yager, Smith, and Crock $(2009,2011,2012)$. Alluvial-aquifer and bedrock-aquifer water generally were calcium/magnesium-sulfate type water, although proportions of sulfate were relatively less in samples from well D17 (calcium/magnesium-bicarbonate type water) and proportions of calcium and magnesium were relatively less in samples from well DTX8A (sodium-calcium-sulfate type water) (Yager, Smith, and Crock, 2004c). Dissolved-oxygen concentration ranged from less than $0.5 \mathrm{mg} / \mathrm{L}$ at most wells to about $8 \mathrm{mg} / \mathrm{L}$ at well D26. All groundwater samples were near neutral $\mathrm{pH}$ (table 5). Specific conductance (measure of ionic strength) ranged from about 350 microsiemens per centimeter at $25^{\circ} \mathrm{C}(\mathrm{mS} / \mathrm{cm})$ at well D19 to about $18,000 \mathrm{mS} / \mathrm{cm}$ at well D6; specific conductance was greater than $1,000 \mathrm{mS} / \mathrm{cm}$ in samples from most monitoring wells. Concentrations of the priority parameters in groundwater samples from the study area during 2004-2010 are summarized by box plots (fig. 7). The boxplots indicate that dissolved nitrite plus nitrate as nitrogen (later referred to as "nitrate" on the basis of data published by Stevens and others, 2003) and selenium had the largest range in concentration in study-area groundwater, and dissolved cadmium, lead, and mercury had the smallest range in concentration of the priority parameters in study-area groundwater. Although concentrations of dissolved nitrate, copper, nickel, selenium, and zinc had large ranges in concentration, the median concentrations of these constituents and the other priority parameters in all groundwater samples from the study area were small (near or less than the MRL) (table 5; fig. 7).

A statistical summary of the concentration of each priority parameter at the nine most frequently sampled monitoring wells during 2004-2010 is shown in figure 8. In addition to the priority parameters, dissolved uranium concentration also is summarized in figure 8 . These boxplots show the concentration data in more detail than in table 5 and show 
Table 5. Summary of all groundwater-quality data collected near Deer Trail, Colorado, during 2004-2010, and groundwater regulatory limits.

[Colorado regulatory standards from Colorado Department of Public Health and Environment (2009); FAO, Food and Agricultural Organization of the United Nations (Pais and Jones, 1997, page 31); CaCO, calcium carbonate; $\mu \mathrm{S} / \mathrm{cm}$, microsiemens per centimeter; ${ }^{\circ} \mathrm{C}$, degrees Celsius; $\mathrm{mg} / \mathrm{L}$, milligrams per liter; E,n, value estimated by laboratory was less than reporting level; $\mu \mathrm{g} / \mathrm{L}$, micrograms per liter; dissolved, passed through a 0.45 micron acrylic copolymer filter for inorganic constituents or through a 0.7 micron glass-fiber filter for organic constituents; --, no standard; <, less than; standards listed for organic constituents are interim chronic or 30-day standards unless otherwise noted]

\begin{tabular}{|c|c|c|c|c|c|c|c|c|c|c|c|c|}
\hline \multirow[b]{2}{*}{$\begin{array}{l}\text { Constituent or } \\
\text { characteristic }\end{array}$} & \multicolumn{4}{|c|}{$\begin{array}{c}\text { Summary of data for all samples, } \\
\text { all wells }\end{array}$} & \multicolumn{4}{|c|}{$\begin{array}{c}\text { Colorado regulatory standards } \\
\text { for groundwater }\end{array}$} & \multicolumn{2}{|c|}{$\begin{array}{l}\text { FA0 recom- } \\
\text { mended } \\
\text { maximum }\end{array}$} & \multirow{2}{*}{$\begin{array}{l}\text { Percentage } \\
\text { of samples } \\
\text { from all } \\
\text { wells that } \\
\text { exceeded a } \\
\text { standard }\end{array}$} & \multirow[b]{2}{*}{$\begin{array}{l}\text { Well where standard } \\
\text { was exceeded }\end{array}$} \\
\hline & $\begin{array}{c}\text { Number } \\
\text { of samples } \\
\text { analyzed }\end{array}$ & $\begin{array}{l}\text { Minimum } \\
\text { for all } \\
\text { samples }\end{array}$ & $\begin{array}{l}\text { Maximum } \\
\text { for all } \\
\text { samples }\end{array}$ & $\begin{array}{l}\text { Median } \\
\text { for all } \\
\text { samples }\end{array}$ & $\begin{array}{c}\text { Human } \\
\text { Health } \\
\text { stan- } \\
\text { dard }\end{array}$ & $\begin{array}{c}\text { Secondary } \\
\text { Drinking } \\
\text { Water } \\
\text { standard }\end{array}$ & $\begin{array}{l}\text { Agricul- } \\
\text { tural } \\
\text { standard }\end{array}$ & $\begin{array}{l}\text { State- } \\
\text { wide } \\
\text { standard }\end{array}$ & $\begin{array}{c}\text { Irriga- } \\
\text { tion } \\
\text { water }\end{array}$ & $\begin{array}{l}\text { Live- } \\
\text { stock }\end{array}$ & & \\
\hline \multicolumn{13}{|c|}{ Inorganic constituents } \\
\hline Dissolved oxygen (field), mg/L & 185 & $<0.5$ & 8.2 & 0.6 & -- & -- & -- & -- & -- & -- & & -- \\
\hline $\mathrm{pH}$ (field), standard units & 188 & 6.4 & 7.6 & 7 & -- & $6.5-8.5$ & $6.5-8.5$ & -- & -- & -- & 0.5 & D4 \\
\hline $\begin{array}{l}\text { Specific conductance (field), } \\
\mu \mathrm{S} / \mathrm{cm} \text { at } 25^{\circ} \mathrm{C}\end{array}$ & 188 & 354 & 17,900 & 4,300 & -- & -- & -- & -- & -- & -- & & -- \\
\hline Hardness, $\mathrm{mg} / \mathrm{L}$ as $\mathrm{CaCO}_{3}$ & 183 & 168 & 13,500 & 2,180 & -- & -- & -- & -- & -- & -- & & -- \\
\hline Calcium, dissolved, $\mathrm{mg} / \mathrm{L}^{3}$ & 184 & 55.6 & 911 & 475.5 & -- & -- & -- & -- & -- & -- & & -- \\
\hline Magnesium, dissolved, mg/L & 184 & 4.9 & 2,960 & 198 & -- & -- & -- & -- & -- & -- & & -- \\
\hline Potassium, dissolved, mg/L & 184 & 0.48 & 17.8 & 7.9 & -- & -- & -- & -- & -- & -- & & -- \\
\hline Sodium, dissolved, $\mathrm{mg} / \mathrm{L}$ & 184 & 7.03 & 2,780 & 321 & -- & -- & -- & -- & -- & -- & & -- \\
\hline Bromide, dissolved, mg/L & 184 & 0.05 & 4.6 & 0.85 & -- & -- & -- & -- & -- & -- & & -- \\
\hline Chloride, dissolved, mg/L & 184 & 2.03 & 423 & 63.1 & -- & 250 & -- & -- & -- & -- & 15.8 & D6 and D6A (all samples) \\
\hline Fluoride, dissolved, mg/L & 184 & 0.2 & 1.8 & 0.97 & 4 & -- & 2 & -- & ${ }^{1} 1$ & 2 & 0 & No data exceeded a standard ${ }^{1}$ \\
\hline Silica, dissolved, mg/L & 184 & 9.05 & 38.1 & 20.7 & -- & -- & -- & -- & -- & -- & & -- \\
\hline Sulfate, dissolved, mg/L & 184 & 20.5 & 14,300 & 2,510 & -- & 250 & -- & -- & -- & -- & 86.4 & All wells except D14, D17, and D19 \\
\hline $\begin{array}{l}\text { Total dissolved solids, residue } \\
\text { on evaporation at } 180^{\circ} \mathrm{C} \text {, } \\
\mathrm{mg} / \mathrm{L}\end{array}$ & 184 & 222 & 23,000 & 4,405 & -- & ${ }^{2} 400$ & -- & ${ }^{2} 10,000$ & -- & -- & 87.0 & $\begin{array}{l}\text { Depending on how background is defined, } \\
\text { all wells except D17 and D19 exceeded } \\
\text { the secondary drinking-water standard. } \\
\text { Wells D6, D6A, and D22 could be clas- } \\
\text { sified "Limited Use and Quality." }\end{array}$ \\
\hline $\begin{array}{l}\text { Nitrogen, ammonia plus organic, } \\
\text { dissolved, } \mathrm{mg} / \mathrm{L} \text { as } \mathrm{N}\end{array}$ & 187 & E,n0.05 & 3.3 & 0.58 & -- & -- & -- & -- & -- & -- & & -- \\
\hline $\begin{array}{l}\text { Nitrogen, ammonia plus organic, } \\
\text { total, } \mathrm{mg} / \mathrm{L} \text { as } \mathrm{N}\end{array}$ & 188 & E,n0.05 & 3.9 & 0.58 & -- & -- & -- & -- & -- & -- & & -- \\
\hline $\begin{array}{l}\text { Nitrogen, ammonia, dissolved, } \\
\mathrm{mg} / \mathrm{L} \text { as N }\end{array}$ & 187 & E,n0.02 & 2.98 & 0.076 & -- & -- & -- & -- & -- & -- & & -- \\
\hline $\begin{array}{l}\text { Nitrogen, nitrite plus nitrate, } \\
\text { dissolved, } \mathrm{mg} / \mathrm{L} \text { as } \mathrm{N}\end{array}$ & 187 & $<0.02$ & 53.8 & 0.87 & 10 & -- & 100 & -- & -- & -- & 18.7 & $\begin{array}{l}\text { D6, D6A, D7, D10, D26, D27, D28, } \\
\text { and D32 exceeded the human health } \\
\text { standard }\end{array}$ \\
\hline $\begin{array}{l}\text { Nitrogen, organic, dissolved, } \\
\text { mg/L }\end{array}$ & 182 & 0.01 & E1.7 & 0.26 & -- & -- & -- & -- & -- & -- & & -- \\
\hline Nitrogen, organic, total, mg/L & 185 & 0.01 & E1.7 & 0.26 & -- & -- & -- & -- & -- & -- & & -- \\
\hline Phosphorus, dissolved, mg/L & 187 & E,n0.02 & 0.89 & 0.04 & -- & -- & -- & -- & -- & -- & & -- \\
\hline Phosphorus, total, mg/L & 187 & E,n0.02 & 0.88 & 0.04 & -- & -- & -- & -- & -- & -- & & -- \\
\hline Aluminum, dissolved, $\mu \mathrm{g} / \mathrm{L}$ & 184 & E,n0.8 & 195 & 3.4 & -- & -- & 5,000 & -- & 5,000 & 5,000 & 0 & No data exceeded a standard \\
\hline Antimony, dissolved, $\mu \mathrm{g} / \mathrm{L}$ & 184 & $<0.04$ & $<2.8$ & $<0.28$ & 6 & -- & -- & -- & -- & -- & 0 & No data exceeded a standard \\
\hline
\end{tabular}


[Colorado regulatory standards from Colorado Department of Public Health and Environment (2009); FAO, Food and Agricultural Organization of the United Nations (Pais and Jones, 1997, page 31); CaCO calcium carbonate $\mu \mathrm{S} / \mathrm{cm}$, microsiemens per centimeter; ${ }^{\circ} \mathrm{C}$, degrees Celsius; $\mathrm{mg} / \mathrm{L}$, milligrams per liter; E,n, value estimated by laboratory was less than reporting level; $\mu \mathrm{g} / \mathrm{L}$, micrograms per liter; dissolved, passed through a 0.45 micron acrylic copolymer filter for inorganic constituents or through a 0.7 micron glass-fiber filter for organic constituents; --, no standard; <, less than; standards listed for organic constituents are interim chronic or 30-day standards unless otherwise noted]

\begin{tabular}{|c|c|c|c|c|c|c|c|c|c|c|c|c|}
\hline \multirow{2}{*}{$\begin{array}{l}\text { Constituent or } \\
\text { characteristic }\end{array}$} & \multicolumn{4}{|c|}{$\begin{array}{l}\text { Summary of data for all samples, } \\
\text { all wells }\end{array}$} & \multicolumn{4}{|c|}{$\begin{array}{l}\text { Colorado regulatory standards } \\
\text { for groundwater }\end{array}$} & \multicolumn{2}{|c|}{$\begin{array}{c}\text { FAO recom- } \\
\text { mended } \\
\text { maximum }\end{array}$} & \multirow{2}{*}{$\begin{array}{c}\text { Percentage } \\
\text { of samples } \\
\text { from all } \\
\text { wells that } \\
\text { exceeded a } \\
\text { standard }\end{array}$} & \multirow{2}{*}{$\begin{array}{l}\text { Well where standard } \\
\text { was exceeded }\end{array}$} \\
\hline & $\begin{array}{l}\text { Number } \\
\text { of samples } \\
\text { analyzed }\end{array}$ & $\begin{array}{l}\text { Minimum } \\
\text { for all } \\
\text { samples }\end{array}$ & $\begin{array}{l}\text { Maximum } \\
\text { for all } \\
\text { samples }\end{array}$ & $\begin{array}{c}\text { Median } \\
\text { for all } \\
\text { samples }\end{array}$ & $\begin{array}{l}\text { Human } \\
\text { health } \\
\text { standard }\end{array}$ & $\begin{array}{l}\text { Secondary } \\
\text { drinking } \\
\text { water } \\
\text { standard } \\
\end{array}$ & $\begin{array}{l}\text { Agricul- } \\
\text { tural } \\
\text { standard }\end{array}$ & $\begin{array}{l}\text { State- } \\
\text { wide } \\
\text { standard }\end{array}$ & $\begin{array}{l}\text { Irriga- } \\
\text { tion } \\
\text { water }\end{array}$ & $\begin{array}{l}\text { Live- } \\
\text { stock }\end{array}$ & & \\
\hline \multicolumn{13}{|c|}{ Inorganic constituents-Continued } \\
\hline Arsenic, dissolved, $\mu \mathrm{g} / \mathrm{L}$ & 184 & E,n0.07 & 11 & 1.35 & 10 & -- & 100 & -- & 100 & 200 & 1.6 & $\begin{array}{l}\text { D6 and D21 exceeded the human-health } \\
\text { standard }\end{array}$ \\
\hline Barium, dissolved, $\mu \mathrm{g} / \mathrm{L}$ & 184 & 4 & 82 & 13 & 2,000 & -- & -- & -- & -- & -- & 0 & No data exceeded a standard \\
\hline Beryllium, dissolved, $\mu \mathrm{g} / \mathrm{L}$ & 183 & E,n0.01 & 1.5 & 0.06 & 4 & -- & 100 & -- & 100 & -- & 0 & No data exceeded a standard \\
\hline Boron, dissolved, $\mu \mathrm{g} / \mathrm{L}$ & 184 & 9.8 & 1,160 & 288 & -- & -- & 750 & -- & -- & 5,000 & 14.7 & D6, D6A, and D22 \\
\hline Cadmium, dissolved, $\mu \mathrm{g} / \mathrm{L}$ & 184 & $<1$ & ${ }^{3} \mathrm{E}, \mathrm{n} 0.02$ & $<1$ & 5 & -- & 10 & -- & 10 & 50 & 0 & No data exceeded a standard \\
\hline Chromium, dissolved, $\mu \mathrm{g} / \mathrm{L}$ & 184 & $<8$ & ${ }^{3} \mathrm{E}, \mathrm{n} 0.02$ & $<8$ & 100 & -- & 100 & -- & 100 & 1,000 & 0 & No data exceeded a standard \\
\hline Cobalt, dissolved, $\mu \mathrm{g} / \mathrm{L}$ & 184 & 0.08 & 11.4 & 1.66 & -- & -- & 50 & -- & 50 & 1,000 & 0 & No data exceeded a standard \\
\hline Copper, dissolved, $\mu \mathrm{g} / \mathrm{L}$ & 184 & $\mathrm{E}, \mathrm{n} 0.21$ & 49.1 & $<10$ & -- & 1,000 & 200 & -- & 200 & 500 & 0 & No data exceeded a standard \\
\hline Iron, dissolved, $\mu \mathrm{g} / \mathrm{L}$ & 184 & $\mathrm{E}, \mathrm{n} 2$ & 17,700 & 24. & -- & 300 & ${ }^{4} 5,000$ & -- & 5,000 & -- & 27.2 & $\begin{array}{l}\text { DTX2, DTX8A, DTX10A, D15, and D16 } \\
\text { exceeded the secondary drinking-water } \\
\text { standard; D21 and D29 exceeded both } \\
\text { the secondary drinking-water and } \\
\text { agricultural standards. }\end{array}$ \\
\hline Lead, dissolved, $\mu \mathrm{g} / \mathrm{L}$ & 184 & $<0.01$ & $<3$ & $<3$ & 50 & -- & 100 & -- & 5,000 & 1,000 & 0 & No data exceeded a standard \\
\hline Manganese, dissolved, $\mu \mathrm{g} / \mathrm{L}$ & 184 & $\mathrm{E}, \mathrm{n} 0.2$ & 9,020 & 986.5 & -- & 50 & ${ }^{5} 200$ & -- & ${ }^{5} 200$ & -- & 89.1 & $\begin{array}{l}\text { DTX1, DTX2, DTX5, DTX8A, DTX10A, } \\
\text { DTX12, D3, D6, D6A, D7, D8, D13, } \\
\text { D14, D15, D16, D17, D20, D21, D22, } \\
\text { D23, D25, D25A, D29, and D31 }{ }^{6}\end{array}$ \\
\hline Mercury, dissolved, $\mu \mathrm{g} / \mathrm{L}$ & 184 & $<0.005$ & $<0.2$ & $<0.2$ & 2 & -- & 10 & -- & -- & 10 & 0 & No data exceeded a standard \\
\hline Molybdenum, dissolved, $\mu \mathrm{g} / \mathrm{L}$ & 184 & 0.5 & 13.3 & 3.5 & 35 & -- & -- & -- & 10 & & 0 & No data exceeded a standard \\
\hline Nickel, dissolved, $\mu \mathrm{g} / \mathrm{L}$ & 184 & 0.37 & 48.3 & 8.1 & 100 & -- & 200 & -- & 200 & 1,000 & 0 & No data exceeded a standard \\
\hline Selenium, dissolved, $\mu \mathrm{g} / \mathrm{L}$ & 184 & 0.06 & 119 & 4.2 & 50 & -- & 20 & -- & 20 & 50 & 0.2 & $\begin{array}{l}\text { DTX1, DTX3, D3, D25 exceeded the } \\
\text { agricultural standard. D6, D6A, and } \\
\text { D33 exceeded both human health and } \\
\text { agricultural standards. }\end{array}$ \\
\hline Silver, dissolved, $\mu \mathrm{g} / \mathrm{L}$ & 184 & $<2.5$ & ${ }^{3} \mathrm{E}, \mathrm{n} 0.01$ & $<2.5$ & 50 & -- & -- & -- & -- & -- & 0 & No data exceeded a standard \\
\hline Strontium, dissolved, $\mu \mathrm{g} / \mathrm{L}$ & 184 & 195 & 20,800 & 5,380 & -- & -- & -- & -- & -- & -- & & -- \\
\hline Tungsten, dissolved, $\mu \mathrm{g} / \mathrm{L}$ & 171 & $<7$ & ${ }^{3} \mathrm{E}, \mathrm{n} 0.01$ & $<7$ & -- & -- & -- & -- & -- & -- & & -- \\
\hline Uranium, dissolved, $\mu \mathrm{g} / \mathrm{L}$ & 184 & 0.09 & 227 & 30.5 & 30 & -- & -- & -- & -- & -- & 51.6 & $\begin{array}{l}\text { DTX1, DTX2, DTX5, DTX6, DTX12, } \\
\text { D6, D6A, D22, D23, D25, D31, and } \\
\text { D32 }\end{array}$ \\
\hline Zinc, dissolved, $\mu \mathrm{g} / \mathrm{L}$ & 184 & $\mathrm{E}, \mathrm{n} 0.3$ & 180 & $<6$ & -- & 5,000 & 2,000 & -- & 2,000 & 25,000 & 0 & No data exceeded a standard \\
\hline
\end{tabular}


Table 5. Summary of all groundwater-quality data collected near Deer Trail, Colorado, during 2004-2010, and groundwater regulatory limits.-Continued

[Colorado regulatory standards from Colorado Department of Public Health and Environment (2009); FAO, Food and Agricultural Organization of the United Nations (Pais and Jones, 1997, page 31); CaCO calcium carbonate $\mu \mathrm{S} / \mathrm{cm}$, microsiemens per centimeter; ${ }^{\circ} \mathrm{C}$, degrees Celsius; $\mathrm{mg} / \mathrm{L}$, milligrams per liter; E, n, value estimated by laboratory was less than reporting level; $\mu \mathrm{g} / \mathrm{L}$, micrograms per liter; dissolved, passed through a 0.45 micron acrylic copolymer filter for inorganic constituents or through a 0.7 micron glass-fiber filter for organic constituents; --, no standard; <, less than; standards listed for organic constituents are interim chronic or 30-day standards unless otherwise noted]

\begin{tabular}{|c|c|c|c|c|c|c|c|c|c|c|c|c|}
\hline \multirow{2}{*}{$\begin{array}{l}\text { Constituent or } \\
\text { characteristic }\end{array}$} & \multicolumn{4}{|c|}{$\begin{array}{c}\text { Summary of data for all samples, } \\
\text { all wells }\end{array}$} & \multicolumn{4}{|c|}{$\begin{array}{l}\text { Colorado regulatory standards } \\
\text { for groundwater }\end{array}$} & \multicolumn{2}{|c|}{$\begin{array}{l}\text { FAO recom- } \\
\text { mended } \\
\text { maximum }\end{array}$} & \multirow{2}{*}{$\begin{array}{c}\text { Percentage } \\
\text { of samples } \\
\text { from all } \\
\text { wells that } \\
\text { exceeded a } \\
\text { standard }\end{array}$} & \multirow{2}{*}{$\begin{array}{l}\text { Well where standard } \\
\text { was exceeded }\end{array}$} \\
\hline & $\begin{array}{c}\text { Number } \\
\text { of samples } \\
\text { analyzed }\end{array}$ & $\begin{array}{c}\text { Minimum } \\
\text { for all } \\
\text { samples }\end{array}$ & $\begin{array}{l}\text { Maximum } \\
\text { for all } \\
\text { samples }\end{array}$ & $\begin{array}{c}\text { Median } \\
\text { for all } \\
\text { samples }\end{array}$ & $\begin{array}{l}\text { Human } \\
\text { health } \\
\text { standard }\end{array}$ & $\begin{array}{c}\text { Secondary } \\
\text { drinking } \\
\text { water } \\
\text { standard }\end{array}$ & $\begin{array}{l}\text { Agricul- } \\
\text { tural } \\
\text { standard }\end{array}$ & $\begin{array}{c}\text { State- } \\
\text { wide } \\
\text { standard }\end{array}$ & $\begin{array}{c}\text { Irriga- } \\
\text { tion } \\
\text { water }\end{array}$ & $\begin{array}{l}\text { Live- } \\
\text { stock }\end{array}$ & & \\
\hline \multicolumn{13}{|c|}{ Organic constituents } \\
\hline $\begin{array}{l}\text { 1,4-Dichlorobenzene, } \\
\text { dissolved, } \mu \mathrm{g} / \mathrm{L}\end{array}$ & 5 & $<0.5$ & $<0.5$ & $<0.5$ & -- & 775 & -- & -- & -- & -- & 0 & No data exceeded a standard \\
\hline $\begin{array}{l}\text { 1-Methylnaphthalene, } \\
\text { dissolved, } \mu \mathrm{g} / \mathrm{L}\end{array}$ & 5 & $<0.5$ & $<0.5$ & $<0.5$ & -- & -- & -- & -- & -- & -- & & -- \\
\hline $\begin{array}{l}\text { 2,6-Dimethylnaphthalene, } \\
\text { dissolved, } \mu \mathrm{g} / \mathrm{L}\end{array}$ & 5 & $<0.5$ & $<0.5$ & $<0.5$ & -- & -- & -- & -- & -- & -- & & -- \\
\hline $\begin{array}{l}\text { 2-Methylnaphthalene, } \\
\text { dissolved, } \mu \mathrm{g} / \mathrm{L}\end{array}$ & 5 & $<0.5$ & $<0.5$ & $<0.5$ & -- & -- & -- & -- & -- & -- & & -- \\
\hline $\begin{array}{l}\text { 3-beta-Coprostanol, } \\
\text { dissolved, } \mu \mathrm{g} / \mathrm{L}\end{array}$ & 5 & $<2$ & $<2$ & $<2$ & -- & -- & -- & -- & -- & -- & & -- \\
\hline $\begin{array}{l}\text { 3-Methyl-1H-indole, } \\
\text { dissolved, } \mu \mathrm{g} / \mathrm{L}\end{array}$ & 5 & $<1$ & $<1$ & $<1$ & -- & -- & -- & -- & -- & -- & & -- \\
\hline $\begin{array}{l}\text { 3-tert-Butyl-4-hydroxyanisole, } \\
\text { dissolved, } \mu \mathrm{g} / \mathrm{L}\end{array}$ & 5 & $<5$ & $<5$ & $<5$ & -- & -- & -- & -- & -- & -- & & -- \\
\hline 4-Cumylphenol, dissolved, $\mu \mathrm{g} / \mathrm{L}$ & 5 & $<1$ & $<1$ & $<1$ & -- & -- & -- & -- & -- & -- & & -- \\
\hline 4-n-Octylphenol, dissolved, $\mu \mathrm{g} / \mathrm{L}$ & 5 & $<1$ & $<1$ & $<1$ & -- & -- & -- & -- & -- & -- & & -- \\
\hline $\begin{array}{l}\text { 4-Nonylphenol } \\
\text { (sum of all isomers), } \\
\text { dissolved, } \mu \mathrm{g} / \mathrm{L}\end{array}$ & 5 & $<5$ & $<5$ & $<5$ & -- & -- & -- & -- & -- & -- & & -- \\
\hline $\begin{array}{l}\text { 4-Nonylphenol diethoxylate } \\
\text { (sum of all isomers), } \\
\text { dissolved, } \mu \mathrm{g} / \mathrm{L}\end{array}$ & 5 & $<5$ & $<5$ & $<5$ & -- & -- & -- & -- & -- & -- & & -- \\
\hline $\begin{array}{l}\text { 4-tert-Octylphenol } \\
\text { diethoxylate, dissolved, } \mu \mathrm{g} / \mathrm{L}\end{array}$ & 5 & $<1$ & $<1$ & $<1$ & -- & -- & -- & -- & -- & -- & & -- \\
\hline $\begin{array}{l}\text { 4-tert-Octylphenol mono-ethoxylate, } \\
\text { dissolved, } \mu \mathrm{g} / \mathrm{L}\end{array}$ & 5 & $<1$ & $<1$ & $<1$ & -- & -- & -- & -- & -- & -- & & -- \\
\hline 4-tert-Octylphenol, dissolved, $\mu \mathrm{g} / \mathrm{L}$ & 5 & $<1$ & $<1$ & $<1$ & -- & -- & -- & -- & -- & -- & & -- \\
\hline $\begin{array}{l}\text { 5-Methyl-1H-benzotriazole, } \\
\text { dissolved, } \mu \mathrm{g} / \mathrm{L}\end{array}$ & 3 & $<2$ & $<2$ & $<2$ & -- & -- & -- & -- & -- & -- & & -- \\
\hline $\begin{array}{l}\text { 9,10-Anthraquinone, } \\
\text { dissolved, } \mu \mathrm{g} / \mathrm{L}\end{array}$ & 5 & $<0.5$ & $<0.5$ & $<0.5$ & -- & -- & -- & -- & -- & -- & & -- \\
\hline Acetophenone, dissolved, $\mu \mathrm{g} / \mathrm{L}$ & 5 & $<0.5$ & ${ }^{3} \mathrm{E}, \mathrm{n} 0.21$ & $<0.5$ & -- & -- & -- & -- & -- & -- & & -- \\
\hline $\begin{array}{l}\text { Acetyl hexamethyl tetrahydro } \\
\text { naphthalene (AHTN), } \\
\text { dissolved, } \mu \mathrm{g} / \mathrm{L}\end{array}$ & 5 & $<0.5$ & $<0.5$ & $<0.5$ & -- & -- & -- & -- & -- & -- & & -- \\
\hline
\end{tabular}


Table 5. Summary of all groundwater-quality data collected near Deer Trail, Colorado, during 2004-2010, and groundwater regulatory limits. - Continued

[Colorado regulatory standards from Colorado Department of Public Health and Environment (2009); FAO, Food and Agricultural Organization of the United Nations (Pais and Jones, 1997, page 31); CaCO, calcium carbonate $\mu \mathrm{S} / \mathrm{cm}$, microsiemens per centimeter; ${ }^{\circ} \mathrm{C}$, degrees Celsius; $\mathrm{mg} / \mathrm{L}$, milligrams per liter; E,n, value estimated by laboratory was less than reporting level; $\mu \mathrm{g} / \mathrm{L}$, micrograms per liter; dissolved, passed through a 0.45 micron acrylic copolymer filter for inorganic constituents or through a 0.7 micron glass-fiber filter for organic constituents; --, no standard; <, less than; standards listed for organic constituents are interim chronic or 30-day standards unless otherwise noted]

\begin{tabular}{|c|c|c|c|c|c|c|c|c|c|c|c|c|}
\hline \multirow{2}{*}{$\begin{array}{l}\text { Constituent or } \\
\text { characteristic }\end{array}$} & \multicolumn{4}{|c|}{$\begin{array}{c}\text { Summary of data for all samples, } \\
\text { all wells }\end{array}$} & \multicolumn{4}{|c|}{$\begin{array}{l}\text { Colorado regulatory standards } \\
\text { for groundwater }\end{array}$} & \multicolumn{2}{|c|}{$\begin{array}{l}\text { FA0 recom- } \\
\text { mended } \\
\text { maximum }\end{array}$} & \multirow{2}{*}{$\begin{array}{l}\text { Percentage } \\
\text { of samples } \\
\text { from all } \\
\text { wells that } \\
\text { exceeded a } \\
\text { standard }\end{array}$} & \multirow[b]{2}{*}{$\begin{array}{l}\text { Well where standard } \\
\text { was exceeded }\end{array}$} \\
\hline & $\begin{array}{l}\text { Number } \\
\text { of samples } \\
\text { analyzed }\end{array}$ & $\begin{array}{l}\text { Minimum } \\
\text { for all } \\
\text { samples }\end{array}$ & $\begin{array}{l}\text { Maximum } \\
\text { for all } \\
\text { samples }\end{array}$ & $\begin{array}{l}\text { Median } \\
\text { for all } \\
\text { samples }\end{array}$ & $\begin{array}{l}\text { Human } \\
\text { health } \\
\text { standard }\end{array}$ & $\begin{array}{c}\text { Secondary } \\
\text { drinking } \\
\text { water } \\
\text { standard } \\
\end{array}$ & $\begin{array}{l}\text { Agricul- } \\
\text { tural } \\
\text { standard }\end{array}$ & $\begin{array}{c}\text { State- } \\
\text { wide } \\
\text { standard }\end{array}$ & $\begin{array}{l}\text { Irriga- } \\
\text { tion } \\
\text { water }\end{array}$ & $\begin{array}{l}\text { Live- } \\
\text { stock }\end{array}$ & & \\
\hline \multicolumn{13}{|c|}{ Organic constituents-Continued } \\
\hline Anthracene, dissolved, $\mu \mathrm{g} / \mathrm{L}$ & 5 & $<0.5$ & $<0.5$ & $<0.5$ & -- & 2,100 & -- & -- & -- & -- & 0 & No data exceeded a standard \\
\hline Benzo[a]pyrene, dissolved, $\mu \mathrm{g} / \mathrm{L}$ & 5 & $<0.5$ & $<0.5$ & $<0.5$ & -- & ${ }^{8} 0.0048-0.2$ & -- & -- & -- & -- & 0 & $\begin{array}{l}\text { No data exceeded a standard, but } \\
\text { MRL } \\
\text { was greater than the standard }\end{array}$ \\
\hline Benzophenone, dissolved, $\mu \mathrm{g} / \mathrm{L}$ & 5 & E,n0.010 & E,n0.042 & E,n0.012 & -- & -- & -- & -- & -- & -- & & -- \\
\hline beta-Sitosterol, dissolved, $\mu \mathrm{g} / \mathrm{L}$ & 5 & $<2$ & $<2$ & $<2$ & -- & -- & -- & -- & -- & -- & & -- \\
\hline beta-Stigmastanol, dissolved, $\mu \mathrm{g} / \mathrm{L}$ & 5 & $<2$ & $<2$ & $<2$ & -- & -- & -- & -- & -- & -- & & -- \\
\hline Bromacil, dissolved, $\mu \mathrm{g} / \mathrm{L}$ & 5 & $<0.5$ & $<0.5$ & $<0.5$ & -- & -- & -- & -- & -- & -- & & -- \\
\hline Caffeine, dissolved, $\mu \mathrm{g} / \mathrm{L}$ & 5 & $<0.5$ & ${ }^{3} \mathrm{E}, \mathrm{n} 0.02$ & $<0.5$ & -- & -- & -- & -- & -- & -- & & -- \\
\hline Camphor, dissolved, $\mu \mathrm{g} / \mathrm{L}$ & 5 & $<0.5$ & ${ }^{3} \mathrm{E}, \mathrm{n} 0.01$ & $<0.5$ & -- & -- & -- & -- & -- & -- & & -- \\
\hline Carbaryl, water, dissolved, $\mu \mathrm{g} / \mathrm{L}$ & 5 & $<1$ & $<1$ & $<1$ & -- & -- & -- & -- & -- & -- & & -- \\
\hline Carbazole, dissolved, $\mu \mathrm{g} / \mathrm{L}$ & 5 & $<0.5$ & $<0.5$ & $<0.5$ & -- & -- & -- & -- & -- & -- & & -- \\
\hline Chlorpyrifos, dissolved, $\mu \mathrm{g} / \mathrm{L}$ & 5 & $<0.5$ & $<0.5$ & $<0.5$ & -- & 21 & -- & -- & -- & -- & 0 & No data exceeded a standard \\
\hline Cholesterol, dissolved, $\mu \mathrm{g} / \mathrm{L}$ & 5 & $<2$ & $<2$ & $<2$ & -- & -- & -- & -- & -- & -- & & -- \\
\hline Cotinine, dissolved, $\mu \mathrm{g} / \mathrm{L}$ & 5 & $<1$ & $<1$ & $<1$ & -- & -- & -- & -- & -- & -- & & -- \\
\hline Diazinon, dissolved, $\mu \mathrm{g} / \mathrm{L}$ & 5 & $<0.5$ & $<0.5$ & $<0.5$ & -- & -- & -- & -- & -- & -- & & -- \\
\hline $\mathrm{d}$-Limonene, dissolved, $\mu \mathrm{g} / \mathrm{L}$ & 5 & $<0.5$ & $<0.5$ & $<0.5$ & -- & -- & -- & -- & -- & -- & & -- \\
\hline Fluoranthene, dissolved, $\mu \mathrm{g} / \mathrm{L}$ & 5 & $<0.5$ & $<0.5$ & $<0.5$ & -- & 280 & -- & -- & -- & -- & 0 & No data exceeded a standard \\
\hline $\begin{array}{l}\text { Hexahydrohexamethylcyclo- } \\
\text { pentabenzopyran (HHCB), } \\
\text { dissolved, } \mu \mathrm{g} / \mathrm{L}\end{array}$ & 5 & $<0.5$ & ${ }^{3} \mathrm{E}, \mathrm{n} 0.01$ & $<0.5$ & -- & -- & -- & -- & -- & -- & & -- \\
\hline Indole, dissolved, $\mu \mathrm{g} / \mathrm{L}$ & 5 & $<0.5$ & $<0.5$ & $<0.5$ & -- & -- & -- & -- & -- & -- & & -- \\
\hline Isoborneol, dissolved, $\mu \mathrm{g} / \mathrm{L}$ & 5 & $<0.5$ & $<0.5$ & $<0.5$ & -- & -- & -- & -- & -- & -- & & -- \\
\hline Isophorone, dissolved, $\mu \mathrm{g} / \mathrm{L}$ & 5 & $<0.5$ & ${ }^{3} \mathrm{E}, \mathrm{n} 0.008$ & $<0.5$ & -- & 140 & -- & -- & -- & -- & 0 & No data exceeded a standard \\
\hline Isopropylbenzene, dissolved, $\mu \mathrm{g} / \mathrm{L}$ & 5 & $<0.5$ & $<0.5$ & $<0.5$ & -- & -- & -- & -- & -- & -- & & -- \\
\hline Isoquinoline, dissolved, $\mu \mathrm{g} / \mathrm{L}$ & 5 & $<0.5$ & $<0.5$ & $<0.5$ & -- & -- & -- & -- & -- & -- & & -- \\
\hline Menthol, dissolved, $\mu \mathrm{g} / \mathrm{L}$ & 5 & $<0.5$ & $<0.5$ & $<0.5$ & -- & -- & -- & -- & -- & -- & & -- \\
\hline Metalaxyl, dissolved, $\mu \mathrm{g} / \mathrm{L}$ & 5 & $<0.5$ & $<0.5$ & $<0.5$ & -- & -- & -- & -- & -- & -- & & -- \\
\hline Methyl salicylate, dissolved, $\mu \mathrm{g} / \mathrm{L}$ & 5 & E,n0.01 & E,n0.03 & E,n0.02 & -- & -- & -- & -- & -- & -- & & -- \\
\hline Metolachlor, dissolved, $\mu \mathrm{g} / \mathrm{L}$ & 5 & $<0.5$ & $<0.5$ & $<0.5$ & -- & -- & -- & -- & -- & -- & & -- \\
\hline $\begin{array}{l}\text { N,N-Diethyl-meta-toluamide } \\
\text { (DEET), dissolved, } \mu \mathrm{g} / \mathrm{L}\end{array}$ & 5 & $<0.5$ & ${ }^{3} \mathrm{E}, \mathrm{n} 0.33$ & $<0.5$ & -- & -- & -- & -- & -- & -- & & -- \\
\hline Naphthalene, dissolved, $\mu \mathrm{g} / \mathrm{L}$ & 5 & $<0.5$ & ${ }^{3} \mathrm{E}, \mathrm{n} 0.02$ & $<0.5$ & -- & 140 & -- & -- & -- & -- & 0 & No data exceeded a standard \\
\hline $\mathrm{p}$-Cresol, dissolved, $\mu \mathrm{g} / \mathrm{L}$ & 5 & $<1$ & $<1$ & $<1$ & -- & -- & -- & -- & -- & -- & & -- \\
\hline Phenanthrene, dissolved, $\mu \mathrm{g} / \mathrm{L}$ & 5 & $<0.5$ & ${ }^{3} \mathrm{E}, \mathrm{n} 0.005$ & $<0.5$ & -- & -- & -- & -- & -- & -- & & -- \\
\hline Phenol, dissolved, $\mu \mathrm{g} / \mathrm{L}$ & 5 & $<0.5$ & ${ }^{3} \mathrm{E}, \mathrm{n} 0.1$ & $<0.5$ & -- & ${ }^{7} 300 / 2,100$ & -- & -- & -- & -- & 0 & No data exceeded a standard \\
\hline Prometon, dissolved, $\mu \mathrm{g} / \mathrm{L}$ & 5 & $<0.5$ & $<0.5$ & $<0.5$ & -- & 100 & -- & -- & -- & -- & 0 & No data exceeded a standard \\
\hline
\end{tabular}


Table 5. Summary of all groundwater-quality data collected near Deer Trail, Colorado, during 2004-2010, and groundwater regulatory limits. -Continued

[Colorado regulatory standards from Colorado Department of Public Health and Environment (2009); FAO, Food and Agricultural Organization of the United Nations (Pais and Jones, 1997, page 31); CaCO, calcium carbonate $\mu \mathrm{S} / \mathrm{cm}$, microsiemens per centimeter; ${ }^{\circ} \mathrm{C}$, degrees Celsius; $\mathrm{mg} / \mathrm{L}$, milligrams per liter; E,n, value estimated by laboratory was less than reporting level; $\mu \mathrm{g} / \mathrm{L}$, micrograms per liter; dissolved, passed through a 0.45 micron acrylic copolymer filter for inorganic constituents or through a 0.7 micron glass-fiber filter for organic constituents; --, no standard; <, less than; standards listed for organic constituents are interim chronic or 30-day standards unless otherwise noted]

\begin{tabular}{|c|c|c|c|c|c|c|c|c|c|c|c|c|}
\hline \multirow{2}{*}{$\begin{array}{l}\text { Constituent or } \\
\text { characteristic }\end{array}$} & \multicolumn{4}{|c|}{$\begin{array}{c}\text { Summary of data for all samples, } \\
\text { all wells }\end{array}$} & \multicolumn{4}{|c|}{$\begin{array}{l}\text { Colorado regulatory standards } \\
\text { for groundwater }\end{array}$} & \multicolumn{2}{|c|}{$\begin{array}{c}\text { FAO recom- } \\
\text { mended } \\
\text { maximum }\end{array}$} & \multirow{2}{*}{$\begin{array}{c}\text { Percentage } \\
\text { of samples } \\
\text { from all } \\
\text { wells that } \\
\text { exceeded a } \\
\text { standard }\end{array}$} & \multirow{2}{*}{$\begin{array}{l}\text { Well where standard } \\
\text { was exceeded }\end{array}$} \\
\hline & $\begin{array}{c}\text { Number } \\
\text { of samples } \\
\text { analyzed }\end{array}$ & $\begin{array}{c}\text { Minimum } \\
\text { for all } \\
\text { samples }\end{array}$ & $\begin{array}{l}\text { Maximum } \\
\text { for all } \\
\text { samples }\end{array}$ & $\begin{array}{c}\text { Median } \\
\text { for all } \\
\text { samples }\end{array}$ & $\begin{array}{c}\text { Human } \\
\text { health } \\
\text { standard }\end{array}$ & $\begin{array}{c}\text { Secondary } \\
\text { drinking } \\
\text { water } \\
\text { standard }\end{array}$ & $\begin{array}{l}\text { Agricul- } \\
\text { tural } \\
\text { standard }\end{array}$ & $\begin{array}{l}\text { State- } \\
\text { wide } \\
\text { standard }\end{array}$ & $\begin{array}{c}\text { Irriga- } \\
\text { tion } \\
\text { water }\end{array}$ & $\begin{array}{l}\text { Live- } \\
\text { stock }\end{array}$ & & \\
\hline \multicolumn{13}{|c|}{ Organic constituents-Continued } \\
\hline Pyrene, dissolved, $\mu \mathrm{g} / \mathrm{L}$ & 5 & $<0.5$ & $<0.5$ & $<0.5$ & -- & 210 & -- & -- & -- & -- & & -- \\
\hline $\begin{array}{l}\text { Tetrachloroethene (PCE), } \\
\text { dissolved, } \mu \mathrm{g} / \mathrm{L}\end{array}$ & 5 & $<0.5$ & $<0.5$ & $<0.5$ & -- & 85 & -- & -- & -- & -- & 0 & No data exceeded a standard \\
\hline $\begin{array}{l}\text { Tribromomethane (bromoform), } \\
\text { dissolved, } \mu \mathrm{g} / \mathrm{L}\end{array}$ & 5 & $<0.5$ & $<0.5$ & $<0.5$ & -- & 4 & -- & -- & -- & -- & & -- \\
\hline $\begin{array}{l}\text { Tributyl phosphate, } \\
\text { dissolved, } \mu \mathrm{g} / \mathrm{L}\end{array}$ & 5 & $<0.5$ & $<0.5$ & $<0.5$ & -- & -- & -- & -- & -- & -- & & -- \\
\hline Triclosan, dissolved, $\mu \mathrm{g} / \mathrm{L}$ & 5 & $<1$ & $<1$ & $<1$ & -- & -- & -- & -- & -- & -- & & -- \\
\hline Triethyl citrate, dissolved, $\mu \mathrm{g} / \mathrm{L}$ & 5 & $<0.5$ & $<0.5$ & $<0.5$ & -- & -- & -- & -- & -- & -- & & -- \\
\hline $\begin{array}{l}\text { Triphenyl phosphate, } \\
\text { dissolved, } \mu \mathrm{g} / \mathrm{L}\end{array}$ & 5 & $<0.5$ & $<0.5$ & $<0.5$ & -- & -- & -- & -- & -- & -- & & -- \\
\hline $\begin{array}{l}\text { Tris(2-butoxyethyl) phosphate } \\
\text { (TBEP), dissolved, } \mu \mathrm{g} / \mathrm{L}\end{array}$ & 5 & $<0.5$ & ${ }^{3} \mathrm{E}, \mathrm{n} 0.1$ & $<0.5$ & -- & -- & -- & -- & -- & -- & & -- \\
\hline $\begin{array}{l}\text { Tris(2-chloroethyl) phosphate, } \\
\text { dissolved, } \mu \mathrm{g} / \mathrm{L}\end{array}$ & 5 & $<0.5$ & $<0.5$ & $<0.5$ & -- & -- & -- & -- & -- & -- & & -- \\
\hline $\begin{array}{l}\text { Tris(dichloroisopropyl) } \\
\text { phosphate, dissolved, } \mu \mathrm{g} / \mathrm{L}\end{array}$ & 5 & $<0.5$ & $<0.5$ & $<0.5$ & -- & -- & -- & -- & -- & -- & & -- \\
\hline
\end{tabular}

phosphate, dissolved, $\mu \mathrm{g} / \mathrm{L}$

${ }^{1}$ Fluoride data for wells D3, D4, D6, D6A, D8, D13, D14, D15, D16, D17, D22, D25, D25A, D31, and DTX10A exceeded the FAO recommended maximum for fluorine in irrigation water.

${ }^{2}$ Or 1.25 times background level, whichever is least restrictive. Groundwaters with a concentration greater than 10,000 $\mathrm{mg} / \mathrm{L}$ do not have a numeric limit and are classified "Limited Use and Quality."

${ }^{3}$ Detected value likely is the maximum; however, censored values could be larger or smaller than the detected value.

${ }^{4}$ Iron data exceeded the agricultural standard only at well D21.

${ }^{5}$ Manganese data exceeded the agricultural standard and the FAO recommended maximum for irrigation water at all wells except DTX3, DTX5, DTX6, DTX8A, D4, D5, D10, D13, D14, D19, D26, D27, D28, D32, and D33.

${ }^{6}$ Manganese data exceeded the secondary drinking water standard at all wells except DTX6, D4, D5, D10, D19, D26, D27, D28, D32, and D33.

${ }^{7}$ Chronic or 30-day standard is 2,100; domestic water supply-drinking water standard is 300 .

${ }^{8}$ Drinking water MCL (Maximum Contaminant Level). 


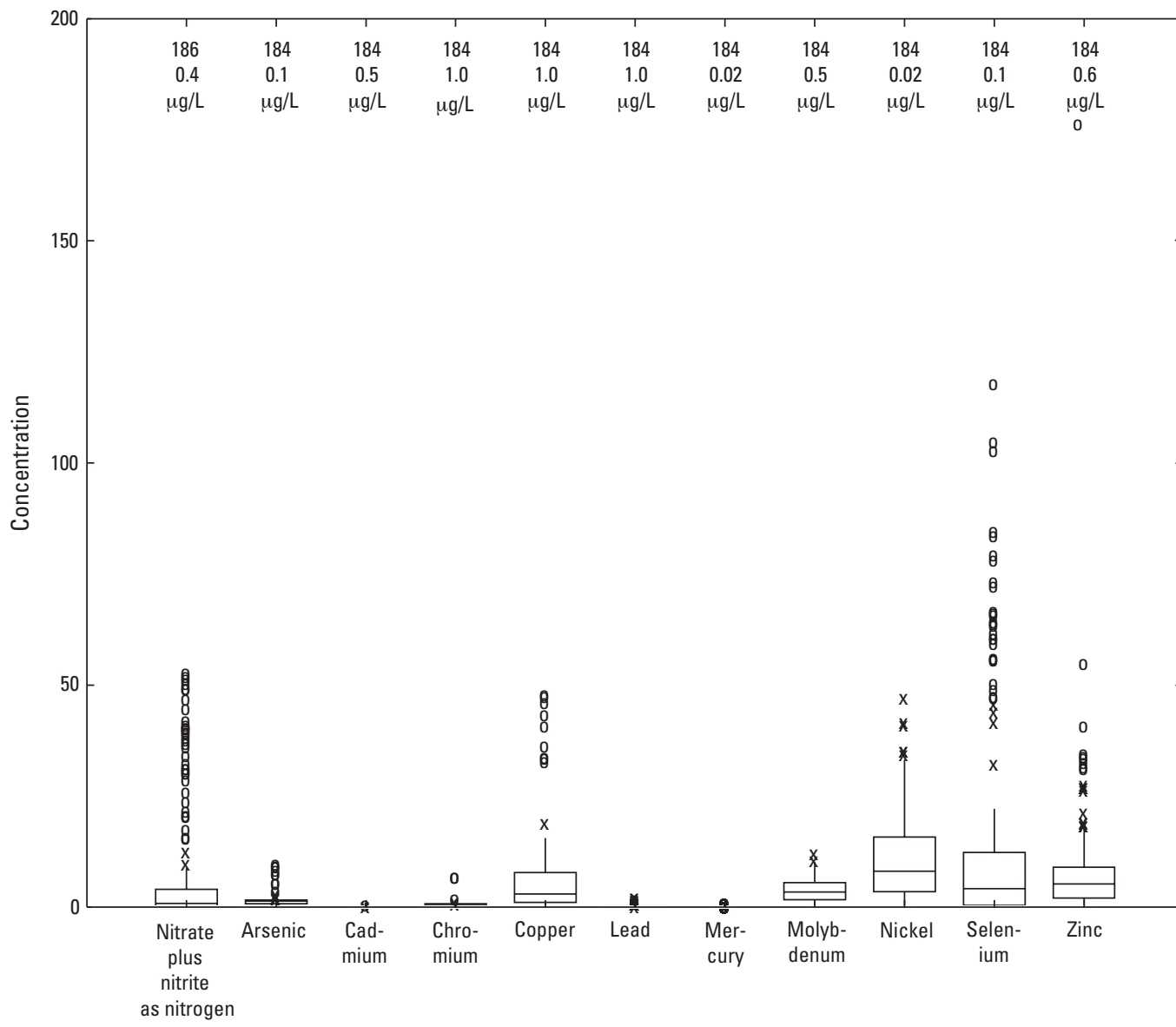

EXPLANATION

186 Number of values

0.4 Minimum reporting leve

$\mu \mathrm{g} / \mathrm{L} \quad$ Unit of measure

$0 \quad$ Upper detached-Value is $\geq 3$ times the interquartile range beyond upper end of box

Upper outside-Value is $>1.5$ times and $<3$ times the interquartile range beyond upper end of box

Upper adjacent-Largest value within 1.5 times interquartile range above 75 th percentile

75th percentile

50th percentile Interquartile

(median)

$$
\text { range }
$$

25th percentile

Lower adjacent-Smallest value within 1.5 times interquartile range below 25 th percentile

$x \quad$ Lower outside-Value is $>1.5$ times and $<3$ times the interquartile range beyond lower end of box

- Lower detached-Value is $\geq 3$ times the interquartile range beyond lower end of box

Figure 7. Boxplots summarizing groundwater quality for selected dissolved constituents from all samples collected near Deer Trail, Colorado, 2004-2010. 
which routinely sampled monitoring wells had the largest concentrations of the selected dissolved constituents. All concentrations of dissolved lead and dissolved mercury were less than the MRL; the reporting level for these and the other constituents varied because of dilution factors and method performance at the laboratory. Except for dissolved arsenic, molybdenum, and nickel concentrations, the concentrations of the selected constituents usually were largest in samples from well D6 (fig. 8). Dissolved arsenic and molybdenum concentrations were largest in samples from well D25. Dissolved nickel concentrations were largest in samples from well DTX1.

The chemistry of groundwater samples from well D6 was unique relative to that of the other monitoring wells in the study area (fig. 8). Specific conductance was at least three times larger at this well than at any other wells in the study, indicating that ion concentrations from dissolved salts are much larger at this location. The chemical data from groundwater samples collected during 2004-2010 confirm that dissolved solids (major elements and salts) were largest in samples from this well (Yager, Smith, and Crock, 2009, 2011, 2012). Concentrations of nitrate in samples from this well consistently were larger than those in samples from other wells (fig. 8). Trace-element concentrations in samples from this well generally were large compared to those in samples from other wells (fig. 8). The concentrated nature of this ground-water means the laboratory had to dilute samples from this well more than other samples from the study, so laboratory uncertainty and MRLs were higher for D6 data than for data from the other monitoring wells. Moreover, the USGS was informed that surface water at the D6 location was considered poor quality for agricultural purposes even in the 1940s (Walter Keen, land owner, oral commun., July 2000). It is important to note that although the inorganic constituent concentrations were relatively large in groundwater samples from well D6, the concentrations of OWCs were not correspondingly large in groundwater from D6 in 2005.

Concentrations of OWCs in the groundwater samples collected in 2005 from all five monitoring wells (including those from well D6) were less than the MRLs with only a few detections. As was the case for biosolids and leachate samples, matrix interference affected the quantification of the sample concentration but rarely affected the identification of target analytes. Concentration values that were larger than the MRL and were affected by matrix interference were estimated by the laboratory. Concentration values that were less than the MRL and identified by the laboratory with high confidence also were estimated by the laboratory. These estimated values, along with any other uncensored concentration above zero that was reported by the laboratory, were considered detections for the groundwater samples in this study. None of the OWCs analyzed were detected in any of the groundwater samples at concentrations above the MRL, although a small percentage of OWCs were detected with certainty at concentrations below the MRL and above the concentration of field and laboratory blanks. Only detections where concentrations were greater than the concentrations in the field blank and in the laboratory blanks were considered valid detections. The largest number of valid detections of OWCs was for the sample from well D25 (six valid detections of OWCs); the fewest number of detections of OWCs was for the sample from well DTX2 (no valid detections of OWCs) (appendix 4). The D6 groundwater sample had only a single valid detection of OWCs (phenanthrene, which was less than the MRL). The D17 groundwater sample also had a single valid detection of OWCs. Bisphenol A initially was included in the wastewaterindicators analysis for groundwater and was detected in two of the groundwater samples (DTX1 and D25), but the USGS later deleted this compound from the wastewater-indicators analysis because of poor quantitative performance of this compound with this method; bisphenol A data, therefore, are not included in table 5. A comparison of the OWCs data for the groundwater samples with those for the biosolids samples indicate that some of the OWCs detected in the groundwater samples could have anthropogenic sources that are not biosolids. Although the MRL was much larger for the leachate data than for the groundwater data because of laboratory dilutions and leachate-sample-matrix issues, this difference in reporting level likely is not the only reason why compounds detected in the groundwater samples were not detected in leachates of biosolids. Phenanthrene can come from vehicle emissions, and DEET is found in the insect repellent that the METROGRO Farm, Metro District, and USGS personnel have at some time worn and sprayed near those sites. Some OWCs detected in the groundwater samples from the study area (acetophenone, DEET, phenanthrene) also were detected in some of the groundwater samples collected from wells around the United States in 2000 that were not near biosolids-application areas (Barnes, Kolpin, Focazio, and others, 2008; Barnes, Kolpin, Furlong, and others, 2008), but many of the OWCs detected in groundwater samples from throughout the United States in 2000 were not detected in groundwater samples from the study area.

Concentrations of priority parameters in groundwater near Deer Trail varied spatially (different concentrations at different locations at the same time) (fig. 8) and temporally (different concentrations at the same locations at different times throughout 2004-2010) (fig. 9). Aquifer variation results from differences in chemistry between aquifers, differences in processes affecting chemistry at different locations of the same aquifer, and changes to the aquifers over time (including those from water-quantity changes as well as those from natural geochemical and microbiogeochemical cycling). Groundwater chemical variation within the aquifer can be interpreted only if that variation is greater than the sample variability and sample bias is minimal.

Sample bias in the groundwater data refers to a shift in concentration data that causes the concentration data to be reported as larger than actual (positive bias) or smaller than actual (negative bias) for a certain span of time. These shifts in concentration usually are caused by sample collection, processing, or analysis and are not caused by aquifer changes. 

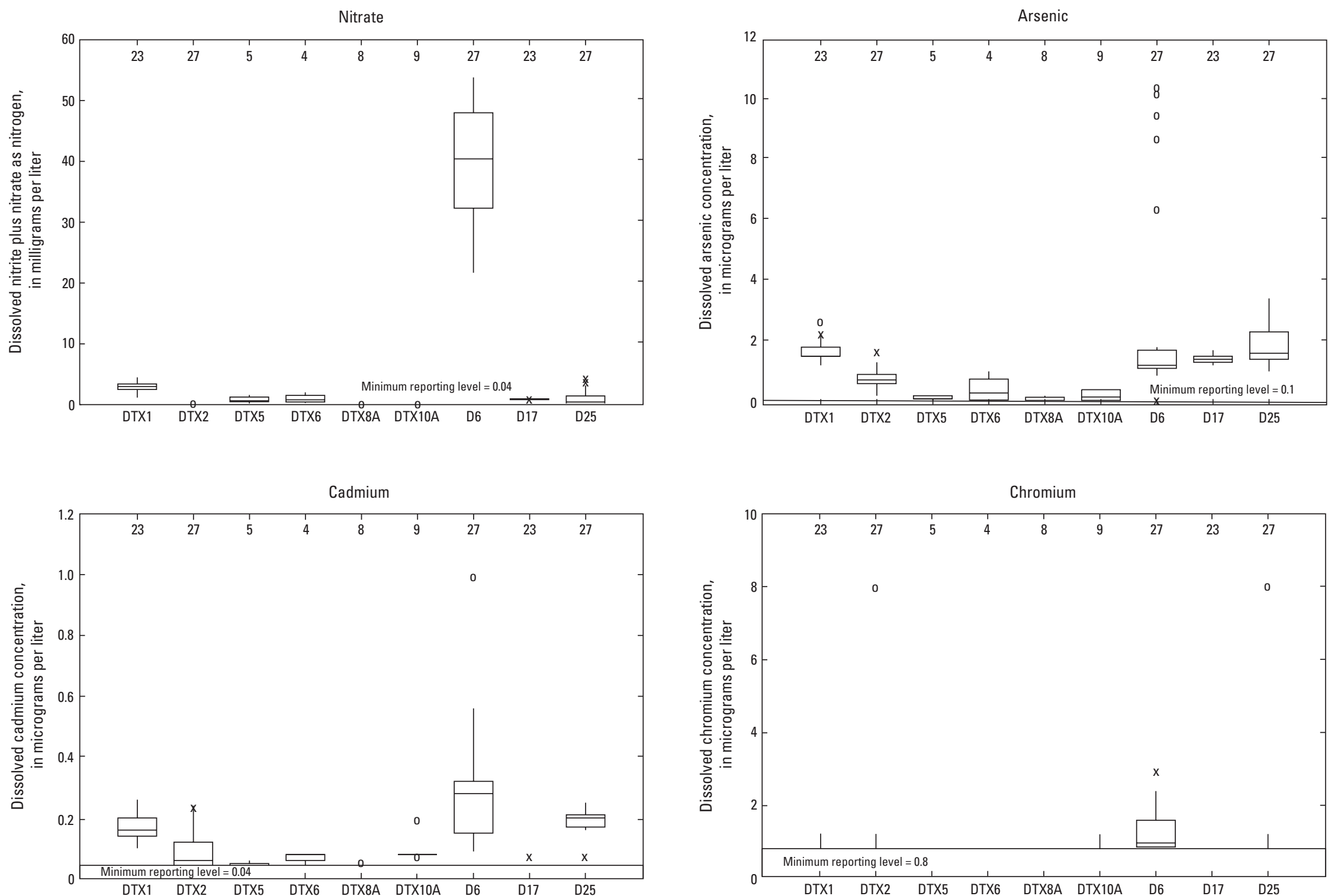

Figure 8. Boxplots summarizing groundwater quality for selected constituents for selected wells near Deer Trail, Colorado, 2004-2010. 

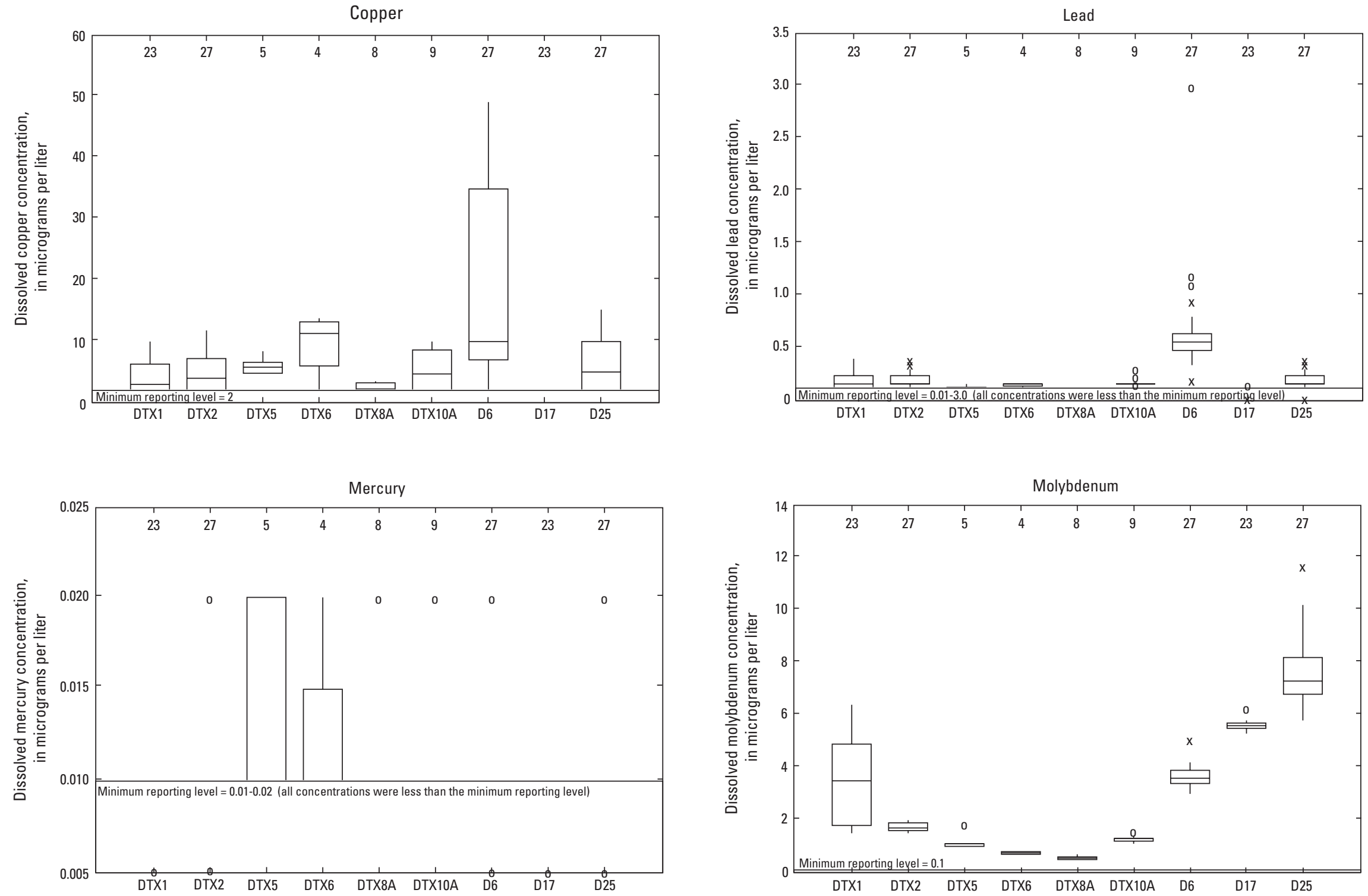

Figure 8. Boxplots summarizing groundwater quality for selected constituents for selected wells near Deer Trail, Colorado, 2004-2010.-Continued 

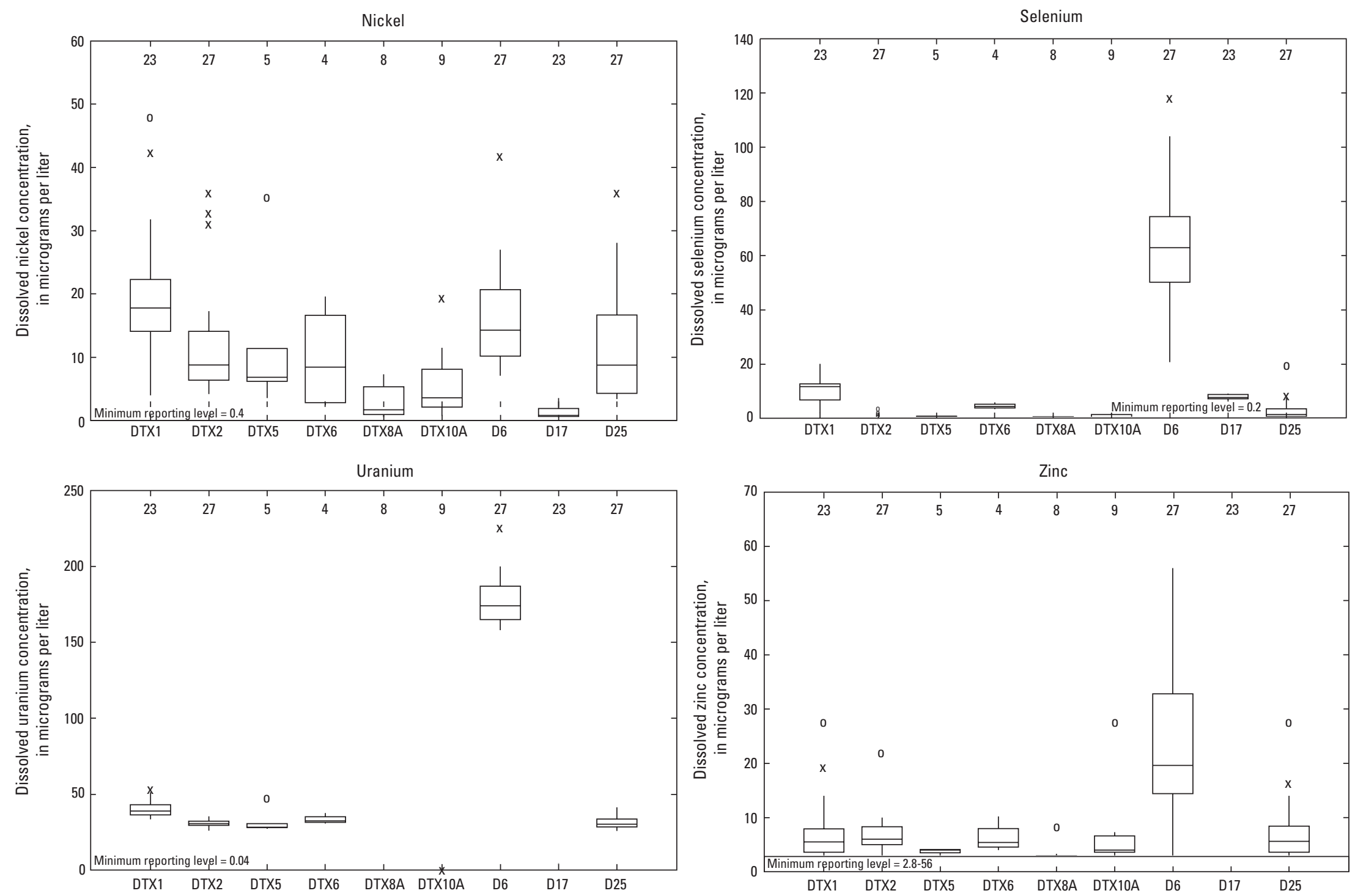

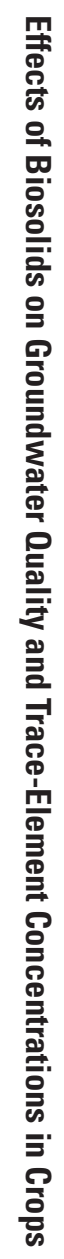

Figure 8. Boxplots summarizing groundwater quality for selected constituents for selected wells near Deer Trail, Colorado, 2004-2010.—Continued 


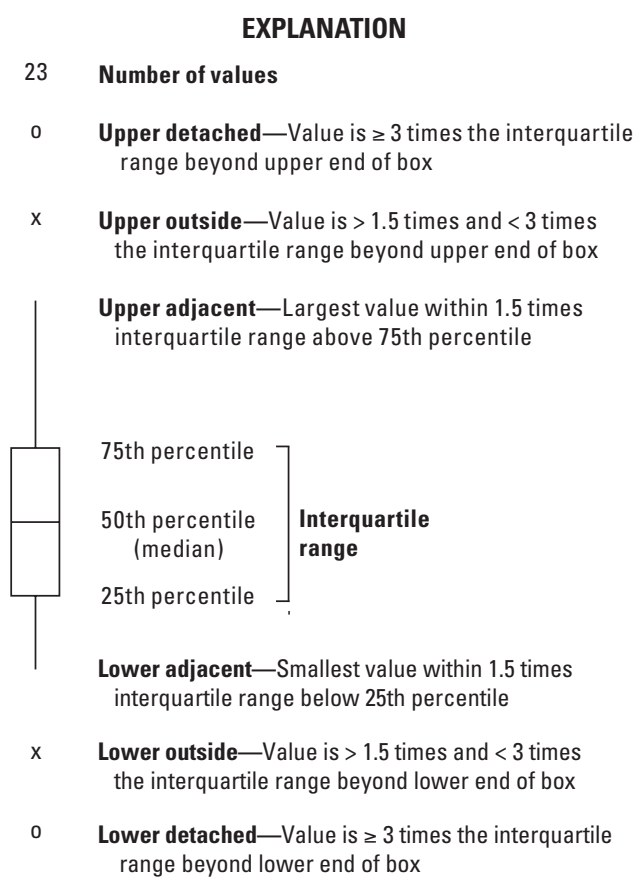

Positive bias in the low concentration range of groundwater data was evaluated by analysis of frequent field blanks as well as annual equipment blanks on the submersible pump. The data from these blanks indicate that sample collection and processing at the alluvial-aquifer wells usually caused no bias, although small concentrations of calcium and chloride were detected in the field blanks for alluvial-groundwater sampling in November 2009 and January 2010 (Yager, Smith, and Crock, 2009, 2011, 2012), and small concentrations of some OWCs were detected in the field blank and laboratory blanks for 2005. The data from the 2004-2010 blanks also indicate that sample collection at the three deepest bedrock-aquifer wells (where the submersible pump was used) could result occasionally in a positive bias in small concentrations of dissolved aluminum, boron, calcium, cobalt, copper, magnesium, manganese, nickel, silver, or zinc during 2004 through 2008 but not during 2009 or 2010 (Yager, Smith, and Crock, 2009, 2011, 2012). Positive or negative bias in inorganic constituents for the low to middle concentration range of groundwater data was evaluated through laboratory standard-reference samples and performance data and through reanalysis of selected samples. Reanalysis of the same selected samples at different times is a quality-assurance feature of the USGS National Water Quality Laboratory (NWQL) that was used to verify unusual values (such as outliers or concentrations detected in blank samples), but most of the reanalysis information also provided at least a qualitative indication of sample bias caused by laboratory analysis. Data for sample reanalyses indicate occasional positive or negative bias in concentrations of dissolved aluminum, arsenic, and many other constituents because of sample analysis (at the laboratory). Quarterly sampling of the same sites during 5 years or more using the same equipment with analyses at the same laboratory (as in this monitoring program) enabled significant sample bias to be recognized and rapidly corrected (where possible). Some of the OWCs (such as benzophenone, caffeine, camphor, DEET, octylphenol, HHCB, and naphthalene) were detected in the July 1995 field blank at concentrations similar to those for the groundwater samples and so indicate a positive bias from the sampling site, equipment, processing personnel, or laboratory analysis that could result in false positives had the positive bias not been noted. Although laboratory quality assurance indicated periods of analytical bias (positive or negative) that could have affected the 2004-2010 data, no sustained or substantial bias was apparent in the laboratory data or other field data.

Sample variability in the groundwater data refers to noise in the data set; that is, differences in concentration values that do not represent aquifer changes, but are an artifact of sample collection, processing, or analysis. Sample variability was evaluated by reanalysis of the same selected samples at different times, by graphical comparison of all concentration data for all sites over time, and by sample-replicate-pair analyses. Reanalysis of the same selected samples at different times is a feature of the NWQL that was used to verify unusual values (such as outliers or concentration differences between replicate pairs). Most of the reanalysis information also provided at least a qualitative indication of sample variability caused by laboratory analytical uncertainty, especially for the analyses of inorganic constituents. Quarterly sampling of the same sites during 5 years or more using the same equipment with analyses at the same laboratory (as in this monitoring program) enabled significant sample variability to be recognized rapidly and at least noted if not corrected. Graphical comparison of all concentration data for all sites over time provided another qualitative indication of sample variability caused by laboratory analytical uncertainty. The replicate samples collected for this component of the monitoring program generally were concurrent (regular- and replicate-sample bottles for the same analysis were filled sequentially, then regular- and replicate-sample bottles for another analysis were filled sequentially, and so on). These replicate data provide quantitative measures of variability primarily from laboratory analytical uncertainty but also from aquifer heterogeneity.

Sample variability was not constant during 2004-2010 but fluctuated over time. Results indicate that sample variability mostly was an artifact of sample analysis caused by laboratory analytical uncertainty (largely a function of analysis technology and error introduced by diluting the samples for the appropriate analytical range). For most of the priority parameters and other constituents, sample variability from analytical uncertainty at the laboratory was decreased through reanalysis. Reanalysis of samples indicated sample variability in 2004-2010 was greatest for concentrations of dissolved calcium, magnesium, antimony, arsenic, barium, chromium, cobalt, copper, iron, lead, manganese, molybdenum, nickel, selenium, uranium, and zinc (Yager, Smith, and Crock, 2009, 

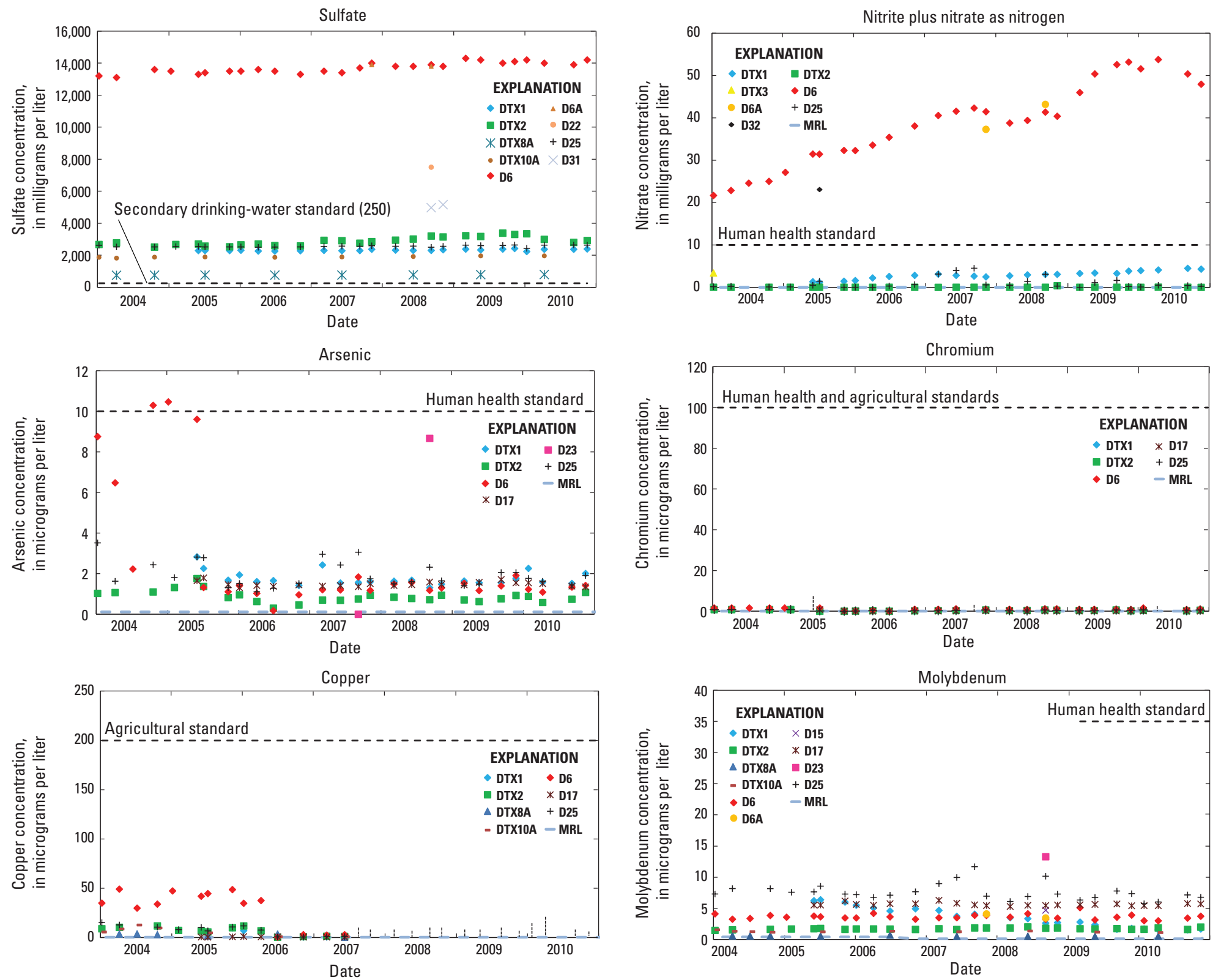

Figure 9. Graphs showing groundwater concentrations near Deer Trail, Colorado, for selected dissolved constituents and selected wells, 20042010. (Dotted vertical lines represent data that were reported by the laboratory as less than the reporting level.) 

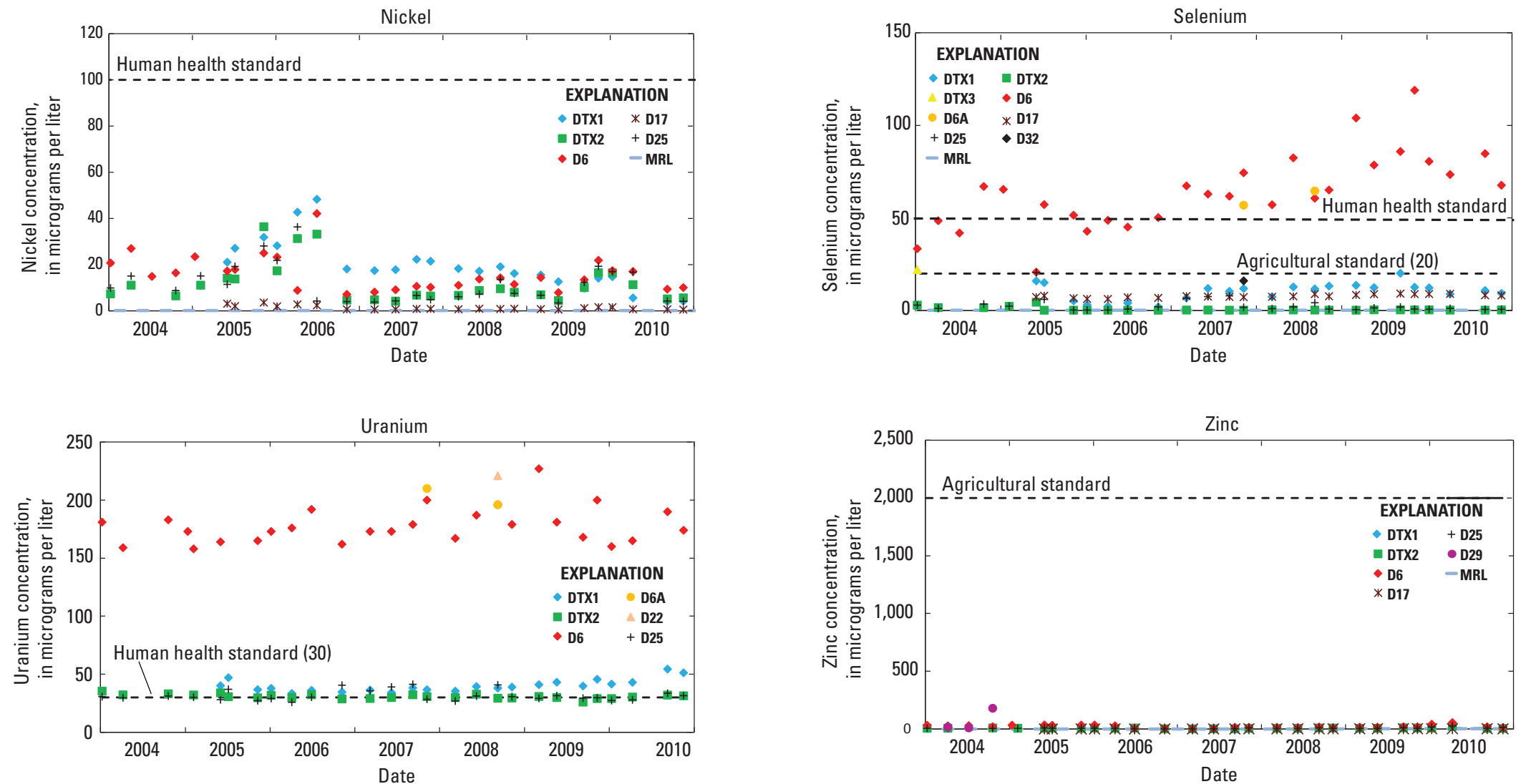

Figure 9. Graphs showing groundwater concentrations near Deer Trail, Colorado, for selected dissolved constituents and selected wells, 20042010. (Dotted vertical lines represent data that were reported by the laboratory as less than the reporting level.)—Continued 
2011, 2012). A graphical comparison of all concentration data indicated that changes in nickel concentration most likely were from analytical variability and not aquifer variation because concentrations for all wells (regardless of location, aquifer type, geology, or depth to water) increased and decreased similarly during 2004-2010 (selected data are included in fig. 9). Results of replicate analyses are more detailed and were used to quantitatively evaluate sample variability. Sample variability for the 2004-2010 data was evaluated at two levels: (1) variability for samples at the time of each analysis as represented by variability measures calculated for each sample-replicate pair and, (2) sample variability for the entire 2004-2010 groundwater data set as represented by summary values such as median absolute difference or median percent difference, as appropriate for the data (table 6). Note that median measures of variability calculated for the 20042010 period will underestimate or overestimate the actual variability at times; variability or uncertainty in the sample data for a given analytical period could be substantially lower or higher than the median. The data for the replicate pairs and corresponding relative percent difference were reported by Yager, Smith, and Crock $(2009,2011,2012)$ for inorganic constituents. Variability measures of relative standard deviation, absolute difference, and percent difference were calculated for each replicate pair (method from Terry Schertz, U.S. Geological Survey, written commun, February 10, 1997). Sample variability computed for 2004-2010 after any data cleanup through reanalysis was greatest in the groundwater data for dissolved calcium, aluminum, chromium, and nickel (table 6). A comparison of the highlighted measure of variability (table 6) with the fluctuation in data (fig. 9) can indicate whether aquifer variation was greater than, about the same as, or less than sample variability. Except for nickel, aquifer variation was greater than the uncertainty (sample variability) for the dissolved groundwater constituents graphed in figure 9 and many of the other groundwater constituents. In general, sample variability was negligible compared to aquifer variation (table 6; fig. 9).

\section{Comparison with Regulatory Standards}

Regulatory standards that might be used as guidelines to evaluate the groundwater quality in the study area are the human health standards and agricultural standards enforced by the State of Colorado (Colorado Department of Public Health and Environment, 2009). For the purposes of this report, the term, groundwater contamination, is defined as groundwater where sample data indicate that regulatory standards have been exceeded (concentrations are larger than regulatory limits), regardless of the source of the contamination. Groundwater concentrations over time for selected dissolved constituents (including the priority parameters) for selected sites (generally those with the highest concentrations) and the lowest regulatory standard are shown in figure 9. Individual concentration values were compared to the Colorado standards to determine whether concentrations in any of the groundwater samples exceeded the standards.

The comparison of individual concentration values indicates that concentrations of priority parameters generally were less than Colorado regulatory limits for groundwater (table 5). All concentrations of dissolved cadmium, chromium, copper, lead, mercury, nickel, and zinc in the groundwater samples from 2004-2010 met the Colorado standards (table 5). Molybdenum concentrations met the new (2009) Colorado Human Health standard of $35 \mu \mathrm{g} / \mathrm{L}$, but some sample concentrations exceeded the Food and Agricultural Organization of the United Nations (FAO; Pais and Jones, 1997) recommended concentration of $10 \mu \mathrm{g} / \mathrm{L}$ for irrigation water (table 5).

The comparison of individual concentration values also indicates that concentrations of some priority parameters (dissolved nitrate, arsenic, and selenium) in samples from some wells exceeded the Colorado regulatory limits for groundwater (table 5). Concentrations of nitrate during 20042010 at wells D6 and D6A all were higher than the Colorado Human Health standard of $10 \mathrm{mg} / \mathrm{L}$ as nitrogen; 18.7 percent of all groundwater samples collected from all wells in the study area during 2004-2010 exceeded this standard (table 5). Arsenic concentrations from wells D6 and D21 exceeded the Colorado Human Health standard of $10 \mu \mathrm{g} / \mathrm{L}$; 1.6 percent of all groundwater samples collected from all wells in the study area during 2004-2010 exceeded this standard (table 5). Selenium concentrations in samples from wells DTX1, DTX3, D3, D6, D6A, D25, and D33 exceeded the Colorado Agricultural standard of $20 \mu \mathrm{g} / \mathrm{L} ; 0.2$ percent of all groundwater samples collected from all wells in the study area during 2004-2010 exceeded this standard (table 5). Selenium concentrations in samples from wells D6, D6A, and D33 also exceeded the Colorado Human Health standard of $50 \mu \mathrm{g} / \mathrm{L}$ (Colorado Department of Public Health and Environment, 2009).

Other inorganic constituents and physical properties also are listed in the Colorado groundwater standards. Some groundwater samples from the study area during 2004-2010 exceeded Colorado standards for chloride, sulfate, total dissolved solids, boron, iron, manganese, and uranium (table 5). The lowest Colorado standard for chloride was exceeded by 15.8 percent of all samples from all monitoring wells in the study area (100 percent of the samples from wells D6 and D6A). The lowest Colorado standard for sulfate was exceeded by 86.4 percent of all samples from all monitoring wells in the study area (which were samples from all wells except D14, D17, and D19). The lowest Colorado standard for total dissolved solids was exceeded by 87.0-94.4 percent of all samples from all monitoring wells in the study area (which were samples from all wells except D17 and D19). The lowest Colorado standard for boron was exceeded by 14.7 percent of all samples from all monitoring wells in the study area (which were samples from wells D6, D6A, and D22). The lowest Colorado standard for iron was exceeded by 27.2 percent of all samples from all monitoring wells in the study area (which were samples from wells DTX2, DTX8A, DTX10A, D15, 
Table 6. Variability estimates for groundwater-quality data computed from comparisons of water-quality data for groundwater and replicate samples collected near Deer Trail, Colorado, 2004-2010.

[Shaded values indicate the measure and value of variability ${ }^{1}$ selected to represent that constituent; values from appendixes 7 through 9 ; for this analysis, all values that were less than the reporting limit were set equal to the reporting limit and estimated values were included; calculations done on unrounded data. Data for the organic wastewater compounds analyzed in 2005 (appendix 4) are not computed in this table because only a single replicate pair was analyzed and the relative percent difference for those analyses was zero for the five compounds that were detected in both samples (all detections were below the reporting level); $\mu \mathrm{S} / \mathrm{cm}$, microsiemens per centimeter; ${ }^{\circ}$, degrees; $\mathrm{mg} / \mathrm{L}$, milligrams per liter; $\mu \mathrm{g} / \mathrm{L}$, micrograms per liter]

\begin{tabular}{|c|c|c|c|c|}
\hline Property or constituent & $\begin{array}{l}\text { Median relative } \\
\text { standard } \\
\text { deviation }\end{array}$ & $\begin{array}{c}\text { Median } \\
\text { absolute } \\
\text { difference }\end{array}$ & $\begin{array}{c}\text { Median } \\
\text { percent } \\
\text { difference }\end{array}$ & $\begin{array}{c}\text { Number of } \\
\text { replicate } \\
\text { samples }\end{array}$ \\
\hline $\mathrm{pH}$, laboratory (standard units) & 0 & 0 & 0 & 28 \\
\hline Specific conductance, lab ( $\mu \mathrm{S} / \mathrm{cm}$ at $25^{\circ}$ Celsius $)$ & 0.28 & 100 & 0.6 & 28 \\
\hline Calcium, dissolved (mg/L) & 1.00 & 8.8 & 2 & 28 \\
\hline Magnesium, dissolved (mg/L) & 1.01 & 45 & 2 & 28 \\
\hline Sodium, dissolved (mg/L) & 1.09 & 45 & 2 & 28 \\
\hline $\begin{array}{l}\text { Acid neutralizing capacity, titration to } \mathrm{pH} 4.5 \text {, } \\
\quad \mathrm{lab}(\mathrm{mg} / \mathrm{L} \text { as calcium carbonate })\end{array}$ & 0.08 & 1 & 0.2 & 28 \\
\hline Bromide, dissolved (mg/L) & 0.57 & 0.04 & 1.1 & 28 \\
\hline Chloride, dissolved (mg/L) & 0.13 & 1 & 0.3 & 28 \\
\hline $\begin{array}{l}\text { Solids, residue on evaporation at } 180^{\circ} \text { Celsius, } \\
\text { dissolved }(\mathrm{mg} / \mathrm{L})\end{array}$ & 0.23 & 100 & 0.5 & 28 \\
\hline $\begin{array}{l}\text { Nitrogen, ammonia plus organic, dissolved } \\
\text { (mg/L as nitrogen) }\end{array}$ & 0.33 & 0.01 & 0.7 & 28 \\
\hline $\begin{array}{l}\text { Nitrogen, ammonia plus organic, total (mg/L } \\
\text { as nitrogen) }\end{array}$ & 0.03 & 0.001 & 0.1 & 28 \\
\hline Nitrogen, ammonia, dissolved (mg/L as nitrogen) & 1.52 & 0.003 & 4 & 28 \\
\hline Nitrite plus nitrate, dissolved (mg/L as nitrogen) & 0.43 & 0.45 & 0.9 & 28 \\
\hline Phosphorus, dissolved (mg/L) & 0.85 & 0 & 0 & 28 \\
\hline Phosphorus, total (mg/L) & 3.13 & 0.002 & 6 & 28 \\
\hline Cadmium, dissolved $(\mu \mathrm{g} / \mathrm{L})$ & 3.23 & 0.01 & 6 & 28 \\
\hline Chromium, dissolved $(\mu \mathrm{g} / \mathrm{L})$ & 0 & 0 & 29 & 28 \\
\hline Cobalt, dissolved $(\mu \mathrm{g} / \mathrm{L})$ & 1.00 & 0.14 & 2 & 28 \\
\hline Copper, dissolved $(\mu \mathrm{g} / \mathrm{L})$ & 0.39 & 0.08 & 0.8 & 28 \\
\hline Iron, dissolved $(\mu \mathrm{g} / \mathrm{L})$ & 0 & 0 & 0 & 28 \\
\hline Lead, dissolved $(\mu \mathrm{g} / \mathrm{L})$ & 0 & 0 & 0 & 28 \\
\hline Manganese, dissolved $(\mu \mathrm{g} / \mathrm{L})$ & 1.30 & 100 & 3 & 28 \\
\hline Mercury, dissolved $(\mu \mathrm{g} / \mathrm{L})$ & 0 & 0 & 0 & 28 \\
\hline Molybdenum, dissolved $(\mu \mathrm{g} / \mathrm{L})$ & 1.34 & 0.1 & 3 & 28 \\
\hline Nickel, dissolved $(\mu \mathrm{g} / \mathrm{L})$ & 2.23 & 0.6 & 24 & 28 \\
\hline Selenium, dissolved $(\mu \mathrm{g} / \mathrm{L})$ & 1.96 & 1.9 & 4 & 28 \\
\hline Silver, dissolved ( $\mu \mathrm{g} / \mathrm{L})$ & 0 & 0 & 0 & 28 \\
\hline
\end{tabular}


Table 6. Variability estimates for groundwater-quality data computed from comparisons of water-quality data for groundwater and replicate samples collected near Deer Trail, Colorado, 2004-2010.-Continued

[Shaded values indicate the measure and value of variability ${ }^{1}$ selected to represent that constituent; values from appendixes 7 through 9 ; for this analysis, all values that were less than the reporting limit were set equal to the reporting limit and estimated values were included; calculations done on unrounded data. Data for the organic wastewater compounds analyzed in 2005 (appendix 4) are not computed in this table because only a single replicate pair was analyzed and the relative percent difference for those analyses was zero for the five compounds that were detected in both samples (all detections were below the reporting level); $\mu \mathrm{S} / \mathrm{cm}$, microsiemens per centimeter; ${ }^{\circ}$, degrees; $\mathrm{mg} / \mathrm{L}$, milligrams per liter; $\mu \mathrm{g} / \mathrm{L}$, micrograms per liter]

\begin{tabular}{lcccc}
\hline \multicolumn{1}{c}{ Property or constituent } & $\begin{array}{c}\text { Median relative } \\
\text { standard } \\
\text { deviation }\end{array}$ & $\begin{array}{c}\text { Median } \\
\text { absolute } \\
\text { difference }\end{array}$ & $\begin{array}{c}\text { Median } \\
\text { percent } \\
\text { difference }\end{array}$ & $\begin{array}{c}\text { Number of } \\
\text { replicate } \\
\text { samples }\end{array}$ \\
\hline Strontium, dissolved $(\mu \mathrm{g} / \mathrm{L})$ & 0.90 & 300 & 2 & 28 \\
Tungsten, dissolved $(\mu \mathrm{g} / \mathrm{L})$ & 0 & 0 & 0.0 & 26 \\
Zinc, dissolved $(\mu \mathrm{g} / \mathrm{L})$ & 0 & 0 & 22 \\
Uranium, dissolved $(\mu \mathrm{g} / \mathrm{L})$ & 0.57 & 2 & 1.1 \\
\hline
\end{tabular}

${ }^{1}$ Measures of variability (from Terry Schertz, USGS, written commun., February 10, 1997) were calculated as follows: Relative standard deviation $=$ $100(($ square root $(\mathrm{C} 1-\mathrm{C} 2) 2 / 2) /((\mathrm{C} 1+\mathrm{C} 2) / 2))$; Absolute difference $=|\mathrm{C} 1-\mathrm{C} 2|$; Percent difference $=100(|\mathrm{C} 1-\mathrm{C} 2| /((\mathrm{C} 1+\mathrm{C} 2) / 2))$, which is the same as the absolute value of the relative percent difference calculated by Yager, Smith, and Crock $(2009,2011,2012)$, where $\mathrm{C} 1$ is the concentration in the regular sample and C2 is the concentration in the replicate sample. Differences in pairs were not normally distributed, so nonparametric measures (absolute difference and percent difference) are the most appropriate measures. Absolute difference is the best measure when differences between pairs are not larger with larger concentrations. Percent difference is the best measure when differences between pairs are larger with larger concentrations.

${ }^{2}$ Measure of variability selected from additional information about laboratory performance because the measure indicated by absolute difference would underrepresent variability for that constituent.

D16, D21, and D29). The lowest Colorado standard for manganese was exceeded by 89.1 percent of all samples from all monitoring wells in the study area (which were samples from most wells). The lowest Colorado standard for uranium was exceeded by 51.6 percent of all samples from all monitoring wells in the study area (which were samples from wells DTX1, DTX2, DTX5, DTX6, DTX12, D6, D6A, D22, D23, D25, D31, and D32). Concentrations of other elements generally were less than Colorado regulatory limits for groundwater (table 5). Groundwater $\mathrm{pH}$ usually met the Colorado Secondary Drinking Water standard. Concentrations for fluoride, aluminum, barium, cobalt, and silver in all groundwater samples from all monitoring wells in the study area met the Colorado standards.

Of the many OWCs analyzed, only 12 compounds had regulatory limits for Colorado groundwater: 1,4-dichlorobenzene, benzo[a]pyrene, anthracene, chlorpyrifos, fluoranthene, isophorone, naphthalene, phenol, prometon, pyrene, tetrachloroethene (PCE), and tribromomethane (bromoform) (Colorado Department of Public Health and Environment, 2009). The concentrations of the 12 regulated OWCs in the samples collected in 2005 from the five alluvial-aquifer wells all met the Colorado standards, although the laboratory reported concentrations for benzo[a]pyrene as less than the MRL, which was higher than the Colorado standard (table 5).

A comparison of individual sample values with regulatory standards, however, provides information only for the time when the sample was collected and does not address sample variability or aquifer variation. For constituents in which all sample-concentration data were considerably below or above the regulatory standard, a statistical analysis may not be necessary to evaluate possible exceedances of standards. Examples include the exceedance of the human health standards for nitrate and uranium and exceedance of the agricultural standard for selenium by concentrations from well D6 groundwater samples. Where some concentration values were close to the regulatory standard, however, an impartial evaluation through statistical tests or summaries is helpful. Examples include the exceedance of the human health standards for arsenic and selenium by concentrations from well D6 groundwater samples, the exceedance of the agricultural standard for selenium by concentrations from well DTX1 groundwater samples, and the exceedance of the human health standards for uranium by concentrations from well DTX2 and well D25 groundwater samples.

Concentrations of selected constituents (including the priority parameters) were statistically tested against the Colorado regulatory standards for sites that had sufficient data. A one-tailed Sign Test (Helsel and Hirsch, 2002) was used to indicate the level of statistical evidence that groundwater concentrations for selected constituents were significantly greater than regulatory standards during 2004-2010 considering sample variability and aquifer variation. A small $p$-value result from the Sign Test indicates more evidence that groundwater concentrations were significantly greater than the regulatory standards. A $p$-value closer to 1.0 indicates less evidence that groundwater concentrations were significantly greater than regulatory standards. For this test, only a $p$-value less than 0.025 indicates that groundwater concentrations were significantly (alpha $=0.05)$ greater than regulatory standards.

A statistical evaluation of selected water-quality data for five alluvial-aquifer wells by using the Sign Test indicates that groundwater concentrations for 2004-2010 were significantly $($ alpha $=0.05)$ higher than the lowest regulatory standard for dissolved nitrate (one well), selenium (one well), and uranium (two wells) (table 7). Concentrations of dissolved nitrate, 
Table 7. Summary of results for statistical evaluation of groundwater-quality data for selected constituents in samples from selected wells near Deer Trail, Colorado, 2004-2010.

[Summary from information provided in appendixes 10 and 11; values less than the minimum reporting level were set equal to the highest minimum reporting level for this evaluation; standard is from Colorado Department of Public Health and Environment (2009); dissolved constituents obtained from samples filtered at $0.45 \mathrm{microns} ; \mathrm{mg} / \mathrm{L}$, milligrams per liter; <, less than; $\mu \mathrm{g} / \mathrm{L}$, micrograms per liter; $>$, greater than; NA, not applicable; \%, percent]

\begin{tabular}{|c|c|c|c|c|c|c|}
\hline \multirow[b]{2}{*}{ Constituent, unit } & \multirow[b]{2}{*}{$\begin{array}{l}\text { Number } \\
\text { of wells } \\
\text { considered }\end{array}$} & \multirow[b]{2}{*}{$\begin{array}{l}\text { Number of } \\
\text { samples at each } \\
\text { well considered } \\
\text { (N) }\end{array}$} & \multicolumn{2}{|l|}{ Exceedance of standards } & \multicolumn{2}{|l|}{ Trends } \\
\hline & & & $\begin{array}{l}\text { Are groundwater concentrations during } \\
2004-2010 \text { significantly (alpha }=0.05 \text { ) higher } \\
\text { than the lowest regulatory standard? }\end{array}$ & $\begin{array}{l}p \text {-value for } \\
\text { sign test }\end{array}$ & $\begin{array}{l}\text { Did concentrations of groundwater in the vicinity } \\
\text { of biosolids application increase significantly } \\
\text { (alpha }=0.05,0.10 \text { ) with time during 2004-2010? }\end{array}$ & $\begin{array}{l}p \text {-value for } \\
\text { upward trends }\end{array}$ \\
\hline $\begin{array}{l}\text { Nitrite plus nitrate, dissolved, } \\
\mathrm{mg} / \mathrm{L} \text { as nitrogen }\end{array}$ & 5 & $23-27$ & Yes (well D6 ${ }^{1}$ ) & $<0.001$ & Yes (wells DTX1, D6, D17) & $<0.001$ \\
\hline Arsenic, dissolved, $\mu \mathrm{g} / \mathrm{L}$ & 5 & $23-27$ & $\mathrm{No}^{2}$ & $>0.9$ & No & $>0.1$ \\
\hline Cadmium, dissolved, $\mu \mathrm{g} / \mathrm{L}$ & 5 & $23-27$ & No & $>0.9$ & $\mathrm{No}^{3}$ & $>0.1$ \\
\hline Chromium, dissolved, $\mu \mathrm{g} / \mathrm{L}$ & 5 & $23-27$ & No & $>0.9$ & $\mathrm{No}^{3}$ & NA \\
\hline Copper, dissolved, $\mu \mathrm{g} / \mathrm{L}$ & 5 & $23-27$ & No & $>0.9$ & No & NA \\
\hline Lead, dissolved, $\mu \mathrm{g} / \mathrm{L}$ & 5 & $23-27$ & No & $>0.9$ & $\mathrm{No}^{3}$ & NA \\
\hline Mercury, dissolved, $\mu \mathrm{g} / \mathrm{L}$ & 5 & $23-27$ & No & $>0.9$ & $\mathrm{No}^{3}$ & NA \\
\hline Molybdenum, dissolved, $\mu \mathrm{g} / \mathrm{L}$ & 5 & $23-27$ & No & $>0.9$ & Yes (well DTX2) & 0.004 \\
\hline Nickel, dissolved, $\mu \mathrm{g} / \mathrm{L}$ & 5 & $23-27$ & No & $>0.9$ & No & NA \\
\hline Selenium, dissolved, $\mu \mathrm{g} / \mathrm{L}$ & 5 & $23-27$ & Yes (well D6 $6^{4}$ ) & $<0.001$ & Yes (wells D6, D17) & $<0.001$ \\
\hline Silver, dissolved, $\mu \mathrm{g} / \mathrm{L}$ & 5 & $23-27$ & No & $>0.9$ & $\mathrm{No}^{3}$ & NA \\
\hline Tungsten, dissolved, $\mu \mathrm{g} / \mathrm{L}$ & 5 & $23-27$ & No standard & NA & $\mathrm{No}^{3}$ & NA \\
\hline Uranium, dissolved, $\mu \mathrm{g} / \mathrm{L}$ & 5 & $23-27$ & Yes $^{5}$ (wells DTX1, D6) & $<0.001$ & Yes (well DTX1) & 0.004 \\
\hline Zinc, dissolved, $\mu \mathrm{g} / \mathrm{L}$ & 5 & $23-27$ & No & $>0.9$ & $\mathrm{No}^{3}$ & NA \\
\hline
\end{tabular}

${ }^{1}$ The $90 \%$ prediction interval for well D6 included the standard; 100\% of D6 sample values were higher than the human health standard.

${ }^{2}$ However, the $90 \%$ prediction interval for well D6 included the standard, and $7.4 \%$ of D6 sample values were higher than the standard.

${ }^{3}$ All or most concentration data were less than the minimum reporting level, which resulted in a flat trend in groundwater concentration (see appendix 11 for more information).

${ }^{4}$ The $90 \%$ prediction interval for well D6 data was higher than the agricultural standard and included the human health standard; $74 \%$ of D6 sample values were higher than the human health standard and $100 \%$ of D6 sample values were higher than the agricultural standard.

${ }^{5}$ The $90 \%$ prediction interval for wells DTX1 and D6 were higher than the standard (human health); $100 \%$ of DTX1 and D6 sample values were higher than the standard. In addition, the $90 \%$ prediction interval for wells DTX2 and D25 included the standard, and 56\% of the DTX2 and D25 sample values were higher than the standard. 
arsenic, cadmium, chromium, copper, lead, mercury, molybdenum, nickel, selenium, silver, uranium, and zinc for wells DTX1, DTX2, D6, D17, and D25 were statistically tested. Dissolved nitrate concentrations in samples from well D6 significantly (alpha $<0.01$ ) exceeded the Colorado Human Health standard. Dissolved selenium concentrations in samples from well D6 also significantly (alpha $<0.01)$ exceeded the Colorado Human Health and Agricultural standards. Dissolved uranium concentrations in samples from wells DTX1 and D6 significantly (alpha $<0.01$ ) exceeded the Colorado Human Health standard. Concentrations of dissolved arsenic, cadmium, chromium, copper, lead, mercury, molybdenum, nickel, silver, and zinc in groundwater samples from the five routinely sampled alluvial-aquifer wells (DTX1, DTX2, D6, D17, and D25) did not significantly (alpha $=0.05$ ) exceed Colorado regulatory standards. Data for the bedrock-aquifer wells (only five samples for each well) and other alluvial-aquifer wells sampled during 2004-2010 (only one or two samples for each well) were insufficient for statistical analysis.

The 90-percent prediction interval for nonparametric distributions (Helsel and Hirsch, 2002, p. 77-78) was calculated for the 2004-2010 groundwater-quality data for selected sites and also was compared to selected Colorado regulatory standards. For the most part, the comparisons of 90-percent prediction intervals for the 2004-2010 data with the Colorado regulatory standards reinforce the findings from the Sign Test (table 7). The 90-percent prediction interval (alpha $=0.10$ ) for nitrate concentrations in samples from well D6 was higher than the human-health standard. The 90-percent prediction interval $($ alpha $=0.10)$ for selenium concentrations in samples from well D6 was higher than the agricultural standard. The 90-percent prediction interval (alpha $=0.10$ ) for selenium concentrations in samples from well D6 also included the human-health standard. The 90-percent prediction interval $($ alpha $=0.10)$ for uranium concentrations in samples from wells DTX1 and D6 was higher than the human-health standard. The 90-percent prediction interval (alpha $=0.10$ ) for arsenic concentrations in samples from well D6 included the human-health standard for arsenic, but the sign test (alpha = 0.05 ) did not indicate that the arsenic concentrations in samples from well D6 significantly exceeded the human-health standard (table 7). The 90-percent prediction interval (alpha $=$ 0.10) for uranium concentrations in samples from wells DTX2 and D25 included the human-health standard, but the sign test $($ alpha $=0.05)$ did not indicate that the arsenic concentrations in samples from wells DTX2 and D25 significantly exceeded the human-health standard (table 7).

\section{Trends in Concentration}

Upward trends in concentration mean that constituent concentration increases over time, although not necessarily in a straight line. These upward trends in concentration might indicate biosolids, other farm practices, grazing, or even natural processes such as geochemical dissolution are affecting groundwater quality. For this report, the Kendall's tau statistic (Helsel and Hirsch, 2002) was used as a nonparametric measure of correlation between concentration and time. Kendall's tau is a number between negative one and positive one where values approaching negative or positive one indicate increasing strength of the correlation (stronger trend), and a number approaching zero indicates decreasing strength of the correlation. Positive values of Kendall's tau indicate upward trends, and negative values indicate downward trends. Concentrations of nitrate, arsenic, cadmium, chromium, copper, lead, mercury, molybdenum, nickel, selenium, silver, tungsten, uranium, and zinc from wells DTX1, DTX2, D6, D17, and D25 were statistically tested. The results of the statistical testing of the data for trends in selected dissolved constituents (including the priority parameters) are summarized in table 7. A $p$-value is included in table 7; the $p$-value must be less than or equal to 0.05 for the test statistic, tau, to be significant (alpha $=0.05)$ with at least 95-percent confidence. The groundwater data evaluated for trend included many values that were less than the MRL. If all data for a constituent were less than the MRL, or all data were greater than the MRL but were the same value, then the values were tied and no trend could be identified (such as for chromium, lead, mercury, silver, and tungsten at all five wells). Many of the reported concentrations included in the trend analysis were less than the MRL, and the MRL varied over time for most of the constituents. The trends were evaluated with all values (less than and greater than an MRL) recensored to the highest MRL as recommended by Helsel (2005). Using this approach, some significant trends were determined, although some trends likely are artificial and do not reflect aquifer variation. Artificial trends can result from changes in laboratory analytical precision and sensitivity during 2004-2010, which likely was the case for downward copper and nickel trends.

The results of trend analysis on the 2004-2010 data set indicate some statistically significant (alpha $=0.05$ ) upward trends in dissolved groundwater constituents (table 7). The constituent tested that had the greatest number of significant $($ alpha $=0.05)$ upward trends was dissolved nitrate (wells DTX1, D6, and D17). The wells where samples had the greatest number of significant $($ alpha $=0.05)$ upward concentration trends were DTX1 (for dissolved nitrate and uranium), D6 (for dissolved nitrate and selenium), and D17 (for dissolved nitrate and selenium). The only other significant $(\mathrm{alpha}=0.05$ ) upward trend was in dissolved molybdenum concentration for well DTX2. The strongest upward trends were in dissolved nitrate concentration for wells DTX1 and D6. Concentrations of dissolved arsenic, cadmium, chromium, copper, lead, mercury, nickel, silver, tungsten, and zinc data had no significant (alpha $=0.05)$ upward trends (table 7). No additional upward trends were determined at the alpha $=0.10$ significance level. Thus, concentrations of dissolved nitrate (three wells), molybdenum (one well), selenium (two wells), and uranium (one well) in shallow groundwater had significant (alpha $=0.05)$ upward trends in some parts of the study area. 
Biosolids could be contributing to the increasing nitrate concentrations by providing more nitrogen to soil and groundwater than can be used by vegetation or microorganisms. Yager and McMahon (2012) showed that the ground-water nitrate concentrations in the vicinity of well D6 are predominantly from biosolids and/or manure, however, the upward trends in nitrate concentration in the study area may not be caused solely by biosolids applications. There is little indication of a temporal response in concentration (fig. 9) corresponding to individual applications of biosolids (Yager, Smith, and Crock, 2009, 2011, 2012). Upgradient nitrate sources related to land uses before biosolids applications began have not been ruled out. Moreover, the combination of dissolved oxygen and dissolved solids naturally in the groundwater may be inhibiting microbial denitrification at the D6 location. At other sites, such as along the Muddy Creek alluvial aquifer near well D25, redox sampling done in 1999 indicates that vegetation and microorganisms could utilize more nitrogen than is supplied from the various sources; additional nitrogen from biosolids applications has not significantly (alpha $=0.05$ and 0.10 ) increased groundwater nitrate concentrations in samples from well D25.

The results of trend analysis on the 2004-2010 combined data set also indicate a number of statistically significant (alpha $=0.05)$ downward trends in the groundwater-quality data (appendix 11). The constituent tested that had the greatest number of significant $($ alpha $=0.05)$ downward trends was dissolved copper (for wells DTX2, D6, and D25). The wells that had the greatest number of significant (alpha $=0.05$ ) downward concentration trends were wells DTX1 (dissolved molybdenum and nickel) and DTX2 (dissolved copper and uranium). The only other significant (alpha $=0.05$ ) downward concentration trend was in dissolved nickel for well D17. As was noted previously, the downward trends in dissolved copper and nickel concentrations likely are linked to changes in laboratory methods rather than in groundwater concentration. The strongest downward concentration trend was in dissolved molybdenum (DTX1). The constituents tested that had no significant $(\mathrm{alpha}=0.05)$ downward concentration trends were dissolved nitrate, arsenic, cadmium, chromium, lead, mercury, selenium, silver, tungsten, and zinc. No additional downward trends were determined at the alpha $=0.10$ significance level. Thus, of the constituents tested, only concentrations of dissolved molybdenum and uranium in shallow groundwater decreased significantly $($ alpha $=0.05)$ with time during 2004-2010, and these same constituents increased significantly (alpha $=0.05$ ) during 2004-2010 in some parts of the study area.

Some results of trend analysis on the 2004-2010 data set were different than the results of the previous trend analyses on the 1999-2003 data set (Yager, Smith, and Crock, 2004c). Some of the trend directions changed from upward to downward trends (dissolved molybdenum concentration at well DTX1 and dissolved copper concentration at well D25). Some of the trend directions changed from downward to upward trends (dissolved nitrate concentration at well D17). In some cases, the significance of the trend result changed (dissolved nitrate concentration at well DTX1). However, some trend results for 2004-2010 were the same as those for 1999-2003 (dissolved nitrate and selenium concentrations at well D6). The slightly larger number of significant upward trends in the 2004-2010 data compared to the 1999-2003 data may not indicate gross contamination in the study area, but could relate to biosolids applications in that there has been more time for biosolids-affected water to recharge the aquifers. Alternatively, the change in water-quality trends could be related to changes in weather (wet or dry cycles) or recharge patterns.

Additional information about water-quality trends related to weather or recharge is provided by comparing the temporal pattern of concentration (fig. 9) with precipitation patterns (fig. 6) and water-level patterns (fig. 5). Decreased concentrations following precipitation are consistent with groundwater that is recharged (diluted) by water that had lower concentrations of these constituents than the groundwater already in contact with rock and soil at those locations. Increased concentrations following precipitation are consistent with groundwater that is recharged by water that was a source of these constituents, especially if depth to groundwater decreases at that same time. It is possible that the decreased concentrations in dissolved nitrate at well D6 during 2008 resulted from the snowmelt recharge in 2007 that caused dilution in the aquifer about one year after the recharge period; however, the depth to groundwater decreased in 2007 not 2008. The spring 2010 decrease in depth to groundwater at well D6 did correspond with a decrease in concentrations of dissolved nitrate, selenium, and uranium, which indicates the recharge water likely was more dilute than the aquifer water with respect to these constituents and therefore was not the source of these constituents. The decreased depth to water at well D25 during 2006-2007 preceded increasing concentrations of dissolved nitrate, arsenic, molybdenum, and uranium that indicates recharge water could have been the source of these constituents. Groundwater quality, however, did not correlate with weather (wet or dry years or individual precipitation events) or water levels at all sites or for all constituents.

Seasonal patterns in the time-series data may be present for some constituents at some sites but few are evident in figure 9. Seasonal patterns in the water-quality data are less indicative of biosolids effects than of natural geochemical processes because biosolids were not applied to the same locations within the study area on an annual schedule (Yager, Smith, and Crock, 2009, 2011, 2012). The D6 data for dissolved selenium and uranium constituents have an undulating temporal pattern, which could be caused by seasonal effects except that the cycles appear to recur at approximately 2-year periods so the pattern may be more related to cropping cycles. Biosolids applications to any specific location within the study area were done, at most, every 2 years, but often less frequently during 2004-2010, so a biosolids-induced cyclical concentration pattern would not be expected to have a regular 
1- or 2-year time step. At this time, too few data are available to statistically test for seasonal trends with sufficient power (low risk of type II error).

\section{Biosolids Signature}

The mere presence of inorganic chemical constituents in the groundwater does not indicate groundwater contamination or effects from biosolids. The priority parameters and many of the other constituents monitored are naturally occurring elements and compounds in rocks and/or soil (Yager, Smith, and Crock, 2004c; Drever, 1988) and so have geochemical sources as well as a potential biosolids source. Another possible source for most of the priority parameters is the historic use of inorganic fertilizer for agriculture, although Yager and McMahon (2012) determined that inorganic fertilizer was not the source of the groundwater nitrate in the vicinity of well D6. Recall that biosolids was the only fertilizer used on the METROGRO Farm after it became Metro District property in 1993-1995. Also, some constituents were present in high concentrations in groundwater in the study area before biosolids were applied to the study area (Yager, 2013 [in press]). Upward trends in groundwater concentrations of the priority parameters could result from natural processes completely unrelated to biosolids. Many of these constituents are present in the rocks and soils in the study area in about the same concentrations as in biosolids applied to the study area (Yager, Smith, and Crock, 2004c, table 1), but the water of the study area has more contact with soil and rock than biosolids (consider the volume of biosolids indicated by figure 3 compared to the volume of rock and soil at the study area). The preliminary water leach tests on biosolids (mentioned previously in the Biosolids section of this report) provided information about which inorganic and organic chemicals are sufficiently mobile in the Metro District biosolids to move into pore water in the unsaturated zone, surface water (ponds or runoff), or groundwater. These leachate concentrations from biosolids were compared with leachate concentrations from soil (Yager, Smith, and Crock, 2004c) or manure, or rock chemistry (Yager and McMahon, 2012) to determine a preliminary biosolids signature to indicate whether the Metro District biosolids affected study-area water quality. The resulting group of inorganic and organic chemicals that constitute a preliminary biosolids signature for water in the study area are listed in table 3 . A comparison of study-area groundwater concentrations with the preliminary aqueous biosolids signature (table 3 ) can indicate whether the groundwater has recharged through treated (biosolidsapplied) fields. More biosolids-signature components detected indicates stronger evidence that groundwater could have been affected by biosolids applications - even if all groundwater concentrations are below the regulated levels. For example, if the biosolids signature is present in groundwater samples from the study area but no concentrations exceeded regulatory levels, then groundwater recharged through treated fields was not contaminated. If the biosolids signature is not present in groundwater samples from the study area but concentrations of any constituents exceeded regulatory levels, then biosolids applications might not be the source of the contamination. If the biosolids signature is present in groundwater samples of the study area and groundwater concentrations of a constituent exceeded regulatory levels, then biosolids might be contributing to groundwater contamination if biosolids are the primary or substantial source of the constituent. Note that even though not all chemical constituents have the same chemical properties, and some OWCs constituents are considered to partition more to sediment or organic matter than to water, all components of the biosolids signature leached readily into an aqueous solution from biosolids and so have the potential to move into water of the study area.

During 1993-2010, groundwater samples were analyzed for all inorganic components of the biosolids signature presented in table 3: antimony, cadmium, cobalt, copper, molybdenum, nickel, nitrogen, phosphorus, selenium, tungsten, vanadium, and zinc. The groundwater samples collected near Deer Trail during 2004-2010 were analyzed routinely for dissolved nitrogen, molybdenum, tungsten, antimony, cadmium, cobalt, copper, nickel, phosphorus, selenium, and zinc (summarized in table 5; complete data reported by Yager, Smith, and Crock, 2009, 2011, 2012). None of the 2004-2010 groundwater samples were analyzed for vanadium concentrations, but dissolved vanadium was not detected in any 1993-1999 samples from study-area monitoring wells (including D17 and D25) (Yager, 2013 [in press]). Because the inorganic components of the biosolids signature also are naturally occurring, only elevated concentrations of the inorganic components are considered indicative of a biosolids signature; concentrations of the inorganic components at or below the MRL are not considered evidence of the biosolids signature. A larger concentration of an inorganic biosolids-signature component indicates more evidence of the biosolids signature for that component. Nitrate concentrations were largest in samples from wells D6 and D6A (fig. 9) but significantly (alpha $=0.05$ ) increased over time in samples from wells DTX1, D6, and D17. Molybdenum concentrations were detected in samples from all wells, were largest in samples from wells D17, D23, and D25 (fig. 9), and significantly (alpha $=0.05)$ increased over time in samples from well DTX2 (table 7). Tungsten is expected to act geochemically similar to molybdenum (Pais and Jones, 1997); however, tungsten was not detected in any groundwater samples. Antimony concentrations generally were less than or about equal to the MRL in samples from all wells, but one detected value was substantially higher: $1.9 \mathrm{mg} / \mathrm{L}$ at DTX5 on October 21, 2004. Cadmium concentrations generally were less than or about equal to the MRL in samples from all wells, but cadmium was detected in all but one sample from well DTX1 and in all but three samples from well D25. Cobalt was detected in all samples, but concentrations were largest in samples from wells D6A, D15, D6, D22, and DTX2. Copper concentrations in samples from all wells were considerably larger during the first years of the 2004-2010 study; copper 
concentrations were less than the MRL during the later years of the study (fig. 9), likely because of laboratory-method changes. As was mentioned previously, nickel concentration was too variable to identify patterns in the data, but nickel was detected in samples from all wells; nickel concentrations generally were largest in samples from wells DTX1, DTX2, and D6 (fig. 9). Phosphorus concentrations generally were less than or about equal to the MRL in samples from all wells, but phosphorus was detected in all samples from wells D17 and D25 and in all but one sample from well DTX1. Selenium concentrations were largest in samples from wells D6 and D6A (fig. 9), and selenium concentrations significantly (alpha $=0.05$ ) increased over time in samples from wells D6 and D17 (table 7). Zinc concentrations were largest in samples from wells D6 and D29 (fig. 9). Zinc concentrations were slightly larger during the first years of the 2004-2010 study but were less than the MRL during the later years of the study in samples from all wells (Yager, Smith, and Crock, 2009, 2011, 2012), likely because of laboratory-method changes. This inorganic-chemical biosolids-signature information for the five routinely sampled alluvial aquifer wells (DTX1, DTX2, D6, D17, and D25) is summarized in table 8. Wells DTX1 and D25 had the most detections of inorganic biosolidssignature components in groundwater samples (7 components). Well DTX2 had the fewest detections of inorganic biosolids-signature components in groundwater samples (4 components). Most of the inorganic biosolids-signature components were detected in the study-area groundwater samples during 2004-2010, but no well had consistently larger concentrations of all or most inorganic signature components in the samples (table 8).

During 2004-2010, one sample from five shallow wells was analyzed for most of the organic components of the biosolids signature presented in table 3 . The groundwater samples collected near Deer Trail in July 2005, which were analyzed once for detergent degradates (including nonylphenol), disinfectants (including phenol and triclosan), fire retardants (including TBEP), fragrances (including 3-methyl-1H-indole, acetophenone, camphor, $\mathrm{HHCB}$, indole, and menthol), p-cresol, plasticizers (including phthalates and TBEP), and other OWCs (including benzophenone), indicated that few of these organic chemicals (OWCs) were detectable at concentrations greater than those of the field blank. The detection information is summarized in table 8 . The only organic-chemical biosolids-signature components that were detected in any samples from the five wells were acetophenone, benzophenone, camphor, HHCB, phenol, and TBEP (table 8). Of these components, only acetophenone, benzophenone, phenol, and TBEP were valid detections (concentrations greater than those of the field or laboratory blanks). Groundwater samples from only two of the five wells (DTX1 and D25) had valid detections of any organic-chemical biosolids-signature components (table 8). One organic-chemical biosolids-signature component (TBEP) was detected in the sample from well DTX1, and four organic-chemical biosolidssignature components (acetophenone, benzophenone, phenol, and TBEP) were detected in the sample from well D25. Note that phenol (valid detection in the D25 sample) also is a component of the preliminary manure signature (table 4 ). The groundwater samples from wells DTX2, D6, and D17 had no valid detections of any of the organic-chemical biosolidssignature components.

What do the biosolids-signature results tell us? All 29 of the biosolids-signature components were not detected in any of the groundwater samples from the study area, but this is not surprising even if biosolids were contributing contaminants to groundwater. Of the 24 biosolids-signature components that were analytes for the groundwater samples in this study, 9 inorganic components and 4 organic components were detected at biosolids-signature levels in one or more groundwater samples. The biosolids-signature components were not always present at large concentrations in groundwater samples from the study area, and the larger concentrations of these components in groundwater samples were not always from the same wells (table 8). Samples from well D25 had the largest number of biosolids-signature components detected (valid detections of 11 components; shaded in table 8). Samples from well DTX1 had the second largest number of biosolidssignature components detected (valid detections of eight components; shaded in table 8). Samples from wells D6 and D17 had fewer biosolids-signature components detected than those from wells D25 and DTX1 (valid detections of five and six components, respectively; shaded in table 8) and no valid detections of organic-chemical components. Samples from well DTX2 had the fewest number of biosolids-signature components detected (valid detections of 4 components; shaded in table 8) and no valid detections of organic-chemical components. Samples from wells D6, D17, and D25, however, had relatively high concentrations of at least one of the primary inorganic-chemical biosolids-signature components (nitrogen or molybdenum). Therefore, the results for these biosolids-signature components indicate that of the five shallow, alluvial-aquifer wells tested during 2004-2010 for the majority of the biosolids-signature components identified so far, groundwater from wells DTX1 and D25 shows the strongest biosolids signature. Groundwater from wells D6 and D17 shows a possible biosolids signature that is weaker than that from wells DTX1 and D25. Groundwater from well DTX2 shows a possible biosolids signature that is weaker than that from the other four wells evaluated. The biosolidssignature results indicate that the aquifers intercepted by the five routinely sampled wells (especially at wells D25 and DTX1) likely have received some recharge through treated fields or biosolids-affected ponds.

A comparison of the biosolids-signature results for the groundwater samples with other water-quality results for the 2004-2010 groundwater samples is summarized in table 9 . The strength of the aqueous biosolids signature (table 3 ) is a better indicator than exceedance of standards or upward trends for biosolids effects on study-area groundwater because many of the inorganic constituents in the groundwater have sources besides biosolids (such as soil and rock) in the study area, and 
Table 8. Summary of biosolids-signature information for groundwater samples collected from selected monitoring wells near Deer Trail, Colorado, 2004-2010.

[Monitoring well locations are shown in figure 2. Biosolids signature (table 3) derived from analysis of leachate samples for Metro Wastewater Reclamation District biosolids (appendix 4) compared with leachates of soil (if multiple sources). All components were detected at large concentrations in the biosolids samples (table 1; appendix 2). Signature components were either at least one order of magnitude larger concentration in biosolids leachate than in leachate from untreated soil (if component had natural sources) or were present in larger concentration than in blanks (if component had anthropogenic sources). Groundwater data summarized are for dissolved constituents and were reported by Yager, Smith, and Crock (2009, 2011, 2012), Yager and McMahon (2012), or appendix 4. Degree of shading corresponds to weight of evidence that biosolids signature component was present in groundwater samples from that well at elevated concentrations. Detected, uncensored concentration greater than zero reported by the laboratory; conc, concentration; <, less than; =, approximately equal to; MRL, minimum reporting level; med, medium; >, greater than; FB, field blank]

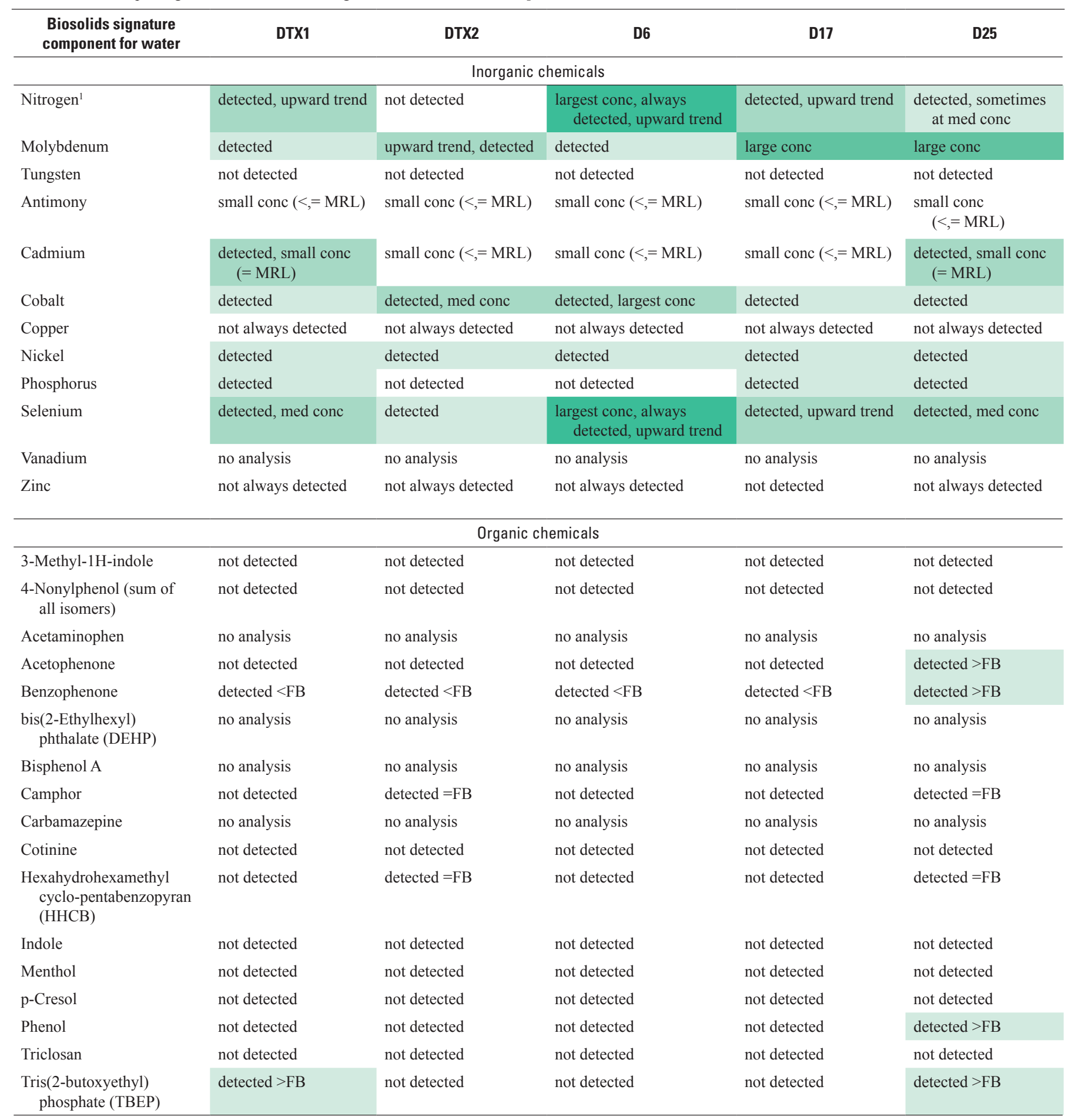

${ }^{1}$ The form of nitrogen is variable because of microbiological cycling. For groundwater of the study area, nitrite plus nitrate as nitrogen was the predominant form. 
Table 9. Indications of biosolids effects on groundwater from samples collected from selected monitoring wells near Deer Trail, Colorado, 2004-2010.

[Shading indicates greater importance in indicating biosolids effects. Groundwater samples were analyzed only once for selected organic chemicals. Biosolidssignature components are listed in table 3; possible manure-signature components are listed in table 4; significantly exceeded, statistically tested using alpha equal to 0.05 ; significant upward trend, statistically tested using apha equal to 0.05 and 0.10 ; OWCs, organic wastewater compounds (data are included in appendix 4); detected, uncensored concentration greater than zero was reported by the laboratory; >, concentration greater than]

\begin{tabular}{|c|c|c|c|c|c|c|c|c|}
\hline $\begin{array}{l}\text { Monitoring } \\
\text { well } \\
\text { (location } \\
\text { shown in } \\
\text { figure 2) }\end{array}$ & $\begin{array}{l}\text { Inorganics, } \\
\text { number of } \\
\text { Colorado } \\
\text { standards ever } \\
\text { exceeded, } \\
\text { 2004-2010 } \\
\text { samples } \\
\text { (table 5) }\end{array}$ & $\begin{array}{c}\text { Inorganics, } \\
\text { number of } \\
\text { Colorado } \\
\text { standards } \\
\text { for priority } \\
\text { parameters } \\
\text { significantly } \\
\text { exceeded, } \\
\text { 2004-2010 } \\
\text { (table 7) }\end{array}$ & $\begin{array}{c}\text { Inorganics, } \\
\text { number of } \\
\text { significant } \\
\text { upward trends } \\
\text { in priority- } \\
\text { parameter } \\
\text { concentrations, } \\
\text { 2004-2010 } \\
\text { (table 7) }\end{array}$ & $\begin{array}{c}\text { Biosolids } \\
\text { signature, } \\
\text { inorganics, } \\
\text { number of } \\
\text { components } \\
\text { routinely } \\
\text { detected } \\
\text { >field blank, } \\
\text { 2004-2010 } \\
\text { (table 8) }\end{array}$ & $\begin{array}{l}\text { Biosolids } \\
\text { signature, } \\
\text { OWCs, } \\
\text { number of } \\
\text { components } \\
\text { detected } \\
\text { >field } \\
\text { blank, } \\
2005 \\
\text { (table 8) }\end{array}$ & $\begin{array}{l}\text { Manure } \\
\text { signature, } \\
\text { OWCs, } \\
\text { number of } \\
\text { components } \\
\text { detected } \\
\text { >field } \\
\text { blank, } \\
2005\end{array}$ & $\begin{array}{c}\text { Other OWCs, } \\
\text { number of } \\
\text { components } \\
\text { detected } \\
\text { >field } \\
\text { blank, } \\
2005\end{array}$ & $\begin{array}{c}\text { Total OWCs, } \\
\text { number of } \\
\text { components } \\
\text { detected } \\
\text { >field } \\
\text { blank, } \\
2005\end{array}$ \\
\hline DTX1 & 5 & 1 & 2 & 7 & 1 & 0 & 0 & 1 \\
\hline DTX2 & 5 & 0 & 1 & 4 & 0 & 0 & 0 & 0 \\
\hline D6 & 9 & 3 & 2 & 5 & 0 & 0 & 1 & 1 \\
\hline D17 & 1 & 0 & 2 & 6 & 0 & 0 & 1 & 1 \\
\hline D25 & 6 & 0 & 0 & 7 & 4 & 12 & 1 & 6 \\
\hline
\end{tabular}

${ }^{1}$ One detected component was also a component of the biosolids signature.

the concentrations of these inorganic constituents are subject to advection and reaction processes in the aquifers that can change the concentrations over time.

Groundwater from well D6 arguably had the worst water quality of the five wells. Concentrations of inorganic constituents in groundwater samples from well D6 exceeded the most regulatory standards (nine) (table 9). Also, the 2004-2010 data significantly (alpha $=0.05$ ) exceeded regulatory standards and had significant (alpha $=0.05$ ) upward concentration trends for the largest number of priority parameters in groundwater from well D6 (three and two, respectively) (table 9). Despite the generally poor quality of groundwater from well D6, the biosolids signature was weak in groundwater samples from D6, and most of the exceedances were from concentrated solutes of geologic origin and were not related to biosolids applications. Given that biosolids applications are a likely source of the nitrogen in the groundwater from well D6 (Yager and McMahon, 2012), the concentrated solutes in the groundwater from well D6 might be obscuring or interfering with the biosolids signature in samples from this well. The groundwater at well D6 likely is affected by biosolids applications to the study area, and the USGS data indicate some adverse effects, such as large and significantly increasing nitrate concentrations.

Groundwater from well D17 had the best water quality of the five wells. Concentrations of inorganic constituents in groundwater samples from well D17 exceeded the fewest regulatory standards (one) (table 9). Also, the 2004-2010 data did not significantly (alpha $=0.05$ ) exceed regulatory standards for any priority parameters but had significant (alpha $=$ 0.05 ) upward concentration trends for two priority parameters (table 9). The biosolids signature in groundwater from well D17 is a little stronger than that from well D6, although groundwater from well D17 naturally has relatively small concentrations of most inorganic constituents. The groundwater from well D17 likely is affected by biosolids applications to the study area, but the USGS data indicate few adverse effects.

Groundwater from well D25 had fair to good water quality. Concentrations of inorganic constituents in groundwater samples from well D25 exceeded six Colorado standards. However, the 2004-2010 data did not significantly (alpha = 0.05 and 0.10 ) exceed regulatory standards or have significant $($ alpha $=0.05)$ upward concentration trends for any priority parameters (table 9). The strongest biosolids signature was in groundwater samples from well D25. The groundwater from well D25 likely is affected by biosolids applications to the study area, but the USGS data indicate few adverse effects.

Groundwater from well DTX1 had fair water quality. Concentrations of inorganic constituents in groundwater samples from well DTX1 exceeded five regulatory standards (table 9). Also, the 2004-2010 data significantly (alpha $=0.05$ ) exceeded regulatory standards for one priority parameter and had significant (alpha $=0.05)$ upward concentration trends for two priority parameters (table 9 ). The biosolids signature in groundwater from well DTX1 was strong and was just a little weaker than that from well D25 (table 9). The groundwater from well DTX1 likely is affected by biosolids applications to the study area, but the USGS data indicate few adverse effects.

Groundwater from well DTX2 also had fair water quality. Concentrations of inorganic constituents in groundwater samples from well DTX2 exceeded five regulatory standards (table 9). The 2004-2010 data did not significantly (alpha = 
$0.05)$ exceed regulatory standards for any priority parameter but had significant (alpha $=0.05$ ) upward concentration trends for one priority parameter (table 9 ). The biosolids signature in groundwater from well DTX2 was the weakest of those from the five wells evaluated (table 9). The groundwater from well DTX2 possibly is affected by biosolids applications to the study area, but the USGS data indicate few (if any) adverse effects.

A comparison of the preliminary manure-signature results for the groundwater samples also is summarized in table 9. Only groundwater from well D25 contained any of the (preliminary) manure-signature compounds, and one of these detected compounds also was a component of the biosolids signature (table 9). Thus, little evidence of a (preliminary) cow-manure signature was discernible in the 2004-2010 groundwater samples from the selected wells, and this preliminary manure signature was not definitive in distinguishing biosolids sources or effects from cow-manure sources or effects.

These results are not conclusive, though. The organicchemical biosolids-signature and manure-signature results are based on the analysis of a single sample from each of just five well locations. The nitrogen and phosphorus detected in the groundwater samples have sources in the study area besides biosolids. All these trace elements have natural geochemical sources. Geochemical sources and natural processes still could account for all the inorganic trace-element concentrations in the groundwater. Also, age dating of a single groundwater sample from wells D6, D17, and D25 in 1998 indicated that groundwater at those sites was too old to show effects from biosolids applications, although the USGS has only moderate confidence in the age-dating results because old and young groundwater seemed to be mixing at some of the sites (Yager and Arnold, 2003, p. 26) and recharge rates can change substantially over time, especially at disturbed sites. Yet, despite the limitations of analyzing so few groundwater samples and the disagreement in the results from different evaluations, some conclusions can be made. The comparison of the biosolids-signature results with the (preliminary) cow-manure signature and other water-quality indicators such as regulatory standards and upward trends indicates that (1) the biosolids-signature approach can be useful in differentiating effects, (2) the use of multiple evaluation approaches increases understanding of complex water-quality issues, (3) biosolids-affected groundwater in the study area can have poor to good water quality, and (4) water-quality problems can result from natural sources and processes in the study area, as well as from biosolids applications.

\section{Crops}

Biosolids can contain elevated concentrations of certain trace elements. The application of biosolids to farmland on which grain crops are grown that will eventually be consumed by animals or humans has led to public concern about the composition and potential contamination of the crops grown on the fields receiving biosolids.

\section{Objectives of Monitoring Crops}

The objective of monitoring crops was to determine if trace-element concentrations in grains harvested from treated (biosolids-applied) fields differed from concentrations in grains harvested from untreated fields in the same general location. The monitoring of crops established independent chemical data sets for the composition of crops to enable the recognition and quantification of significant changes, if any, in crop composition.

\section{Approach for Monitoring Crops}

Crops were monitored for concentrations of the priority parameters in mature grain at two monitoring sites on the METROGRO Farm during 2004-2010. The monitoring locations for crops are shown in figure 2 and, in more detail, in figures 10 and 11. One of the crop-monitoring sites is on Metro District property in Arapahoe County, and one site is on Metro District property in Elbert County. Each site consisted of two control (untreated) fields that did not receive biosolids applications and one treated field (figs. 10 and 11), all of which were farmed at the same time and in the same way. Neither the treated fields nor the untreated fields were irrigated. The treated fields and the untreated fields were tilled, planted, and treated with pesticides at the same time and in the same way; however, the treated fields were fertilized with biosolids and the untreated fields were not fertilized at all.

Crop samples were collected by Metro District personnel or their designees from both the treated fields and from the untreated fields as separate samples. The crop at the monitoring sites usually was a variety of hard red winter wheat, and the farming practice usually included a crop/fallow rotation (Drex Disbrow, Metro Wastewater Reclamation District, written commun., April 12, 2004). Occasionally, the crop sampled was corn. Samples were collected directly from the bin of the harvesting machine during harvest, and each field was harvested separately. During 2004-2010, wheat-grain samples were collected from the Arapahoe County site (2004, 2006, 2008, and 2010) and from the Elbert County site or from a nearby treated field (2006 and 2009). Corn-kernel samples also were collected from treated fields in Elbert County (2006 and 2008).

The crop samples were cleaned, dried, and ground at a USGS facility in Denver, Colo. The prepared samples were analyzed by the USGS for priority parameters, the nine trace elements that are regulated in biosolids (Colorado Department of Public Health and Environment, 2003): arsenic, cadmium, copper, lead, mercury, molybdenum, nickel, selenium, and zinc. Selected samples also were analyzed for sulfur. These 


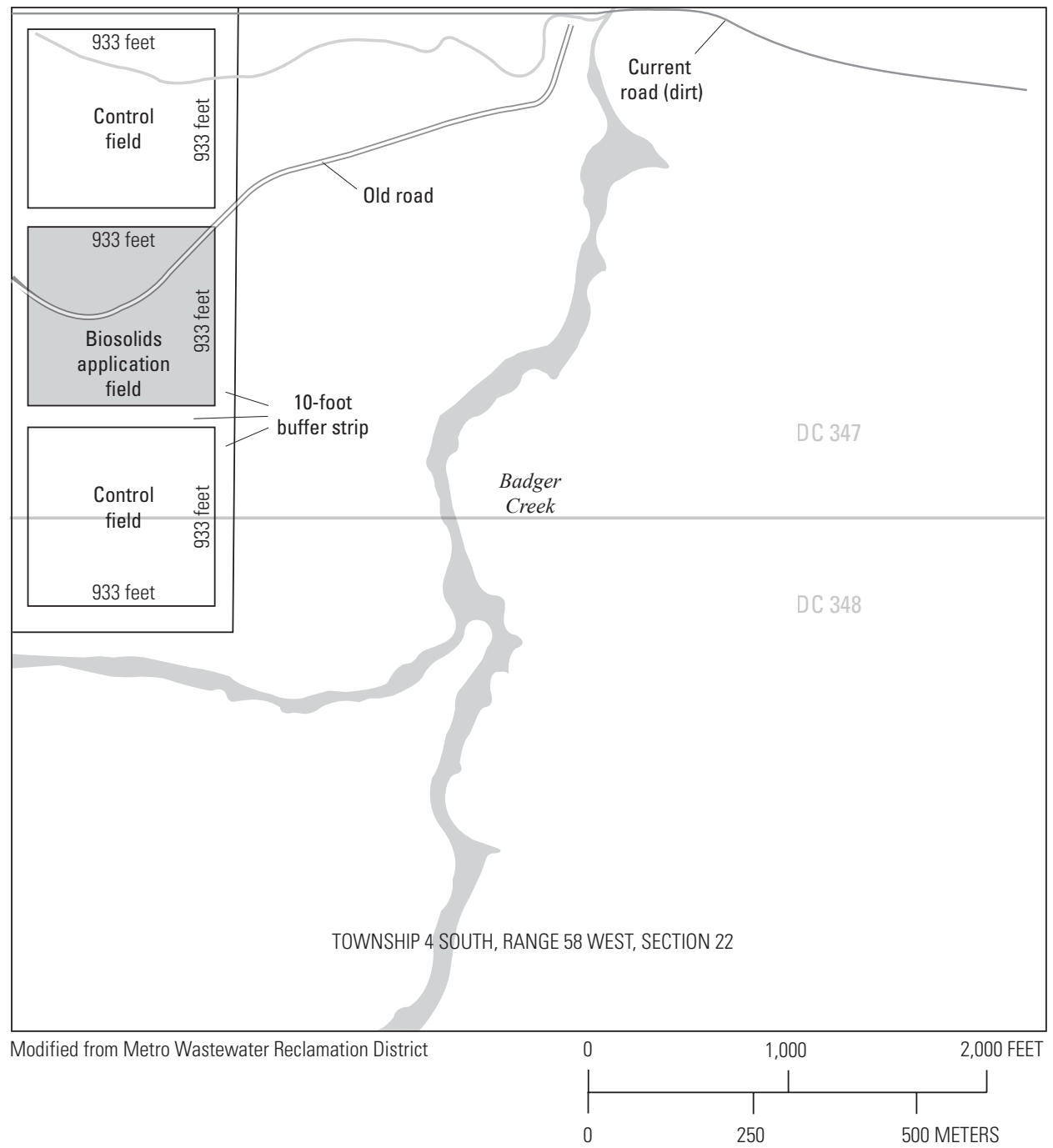

Figure 10. Map showing Arapahoe County, Colorado, crop-sampling area. (DC, Destination Code, which is used to track biosolids applications.)

data and complete details regarding dates of collection, sample-collection protocols, sample preparation, and analytical methods are provided by Yager, Smith, and Crock (2009, 2011, 2012).

\section{Effects of Biosolids on Trace-Element Concentrations in Crops}

Nineteen crop samples were collected during 2004-2010; however, not all the samples were the same crop type and not all samples had paired control-site samples. Only wheat crops had paired treated/untreated samples and were sampled in sufficient numbers to evaluate biosolids effects. The concentration data for the wheat-grain samples are summarized by boxplots (fig. 12). A boxplot for concentration from untreated fields is shown side-by-side with a boxplot for concentration from treated fields for the constituents of concern to show biosolids effects on wheat-grain concentration. Little difference is discernible in the 2004-2010 wheat-grain data between the grain from the untreated fields and the grain from the treated fields. The differences shown could be the product of laboratory variability rather than biosolids effect. The copper and zinc data were particularly variable during 2004-2010 (fig. 12). Wheat grain from all the Arapahoe and Elbert County fields (treated and untreated fields) showed an increase in zinc concentration from 2006 to 2008 of about two orders of magnitude (Yager, Smith, and Crock, 2009, 2011, 2012). Quality-control data were not available to confirm that the variability was introduced from the analysis and not naturally inherent in the sample. Because the concentration change occurred for both treated and untreated fields in each county, it is concluded that the zinc-concentration increase is not an effect of biosolids applications but likely is from analytical bias at the laboratory. A comparison of the 2004-2006 zinc data for crops with the 


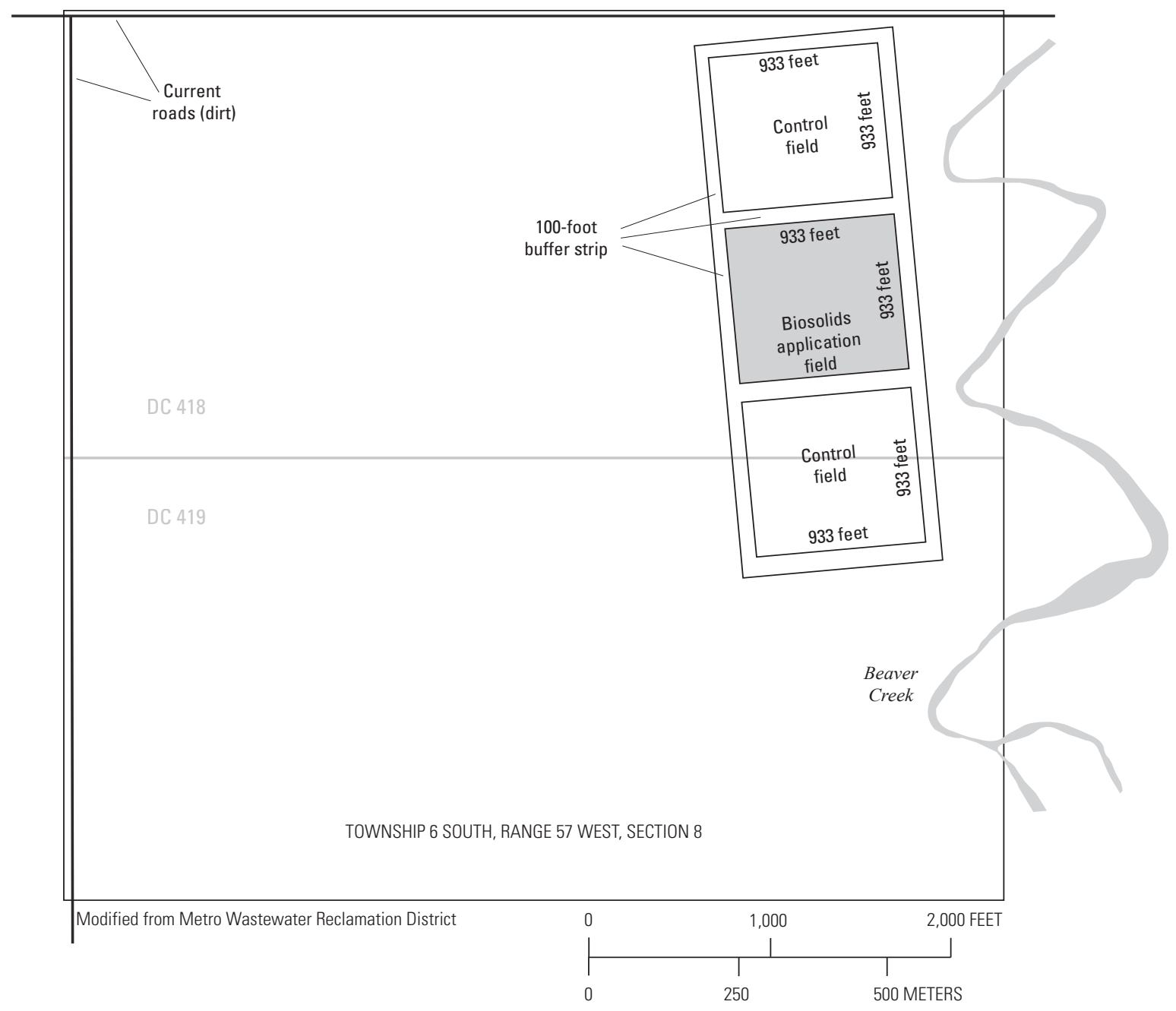

Figure 11. Map showing Elbert County, Colorado, crop-sampling area. (DC, Destination Code, which is used to track biosolids applications.)

2000, 2002, 2008, and 2010 zinc data for crops indicate that the 2004-2006 zinc data for crops could have a large negative bias (Yager, Smith, and Crock, 2004a, 2004c, 2009, 2011, 2012). This negative bias does not affect the comparison of the data for effects from biosolids, however, because both the data for the treated and the untreated fields seem affected by the same laboratory bias.

The wheat-grain data from the treated fields were statistically compared with the wheat-grain data from the untreated fields. A Sign Test (Helsel and Hirsch, 2002) was used to evaluate the median concentrations for the paired samples. The statistical evaluation of the five paired wheat-grain samples did not indicate any evidence $(\mathrm{p}>0.18)$ that biosolids applications significantly (alpha $=0.05$ or 0.10 ) increased concentration of any of these constituents in wheat grain. With only five paired samples, it is difficult to draw definitive conclusions about trends in crop composition or about comparisons between wheat grain grown on the untreated fields with grain grown on the treated fields.
For this reason, the wheat-grain data produced during this study were compared with composition data found in the literature for similar winter wheat where no biosolids were applied. The median concentration of trace metals in wheat collected from the Arapahoe and Elbert County sites during 2004-2010 was used for comparison (table 10). Data for wheat collected from untreated fields in the northern Great Plains of the United States (U.S.) (Erdman and Gough, 1979); Adams County, Colo. (Erdman and Tourtelot, 1976); San Joaquin Valley, Calif. (Severson and others, 1991); and from crop districts in Manitoba, Saskatchewan, and Alberta, Canada (Gawalko and others, 2001) were included in the comparison. For all elements in common among the data sets, the wheat from the study area had similar concentrations to those from the other localities in North America. Therefore, the data for the limited crop samples collected from the METROGRO Farm during 2004-2010 indicate that biosolids applications are not increasing the concentrations of arsenic, cadmium, copper, lead, mercury, molybdenum, nickel, selenium, sulfur, and zinc in mature wheat grain. 


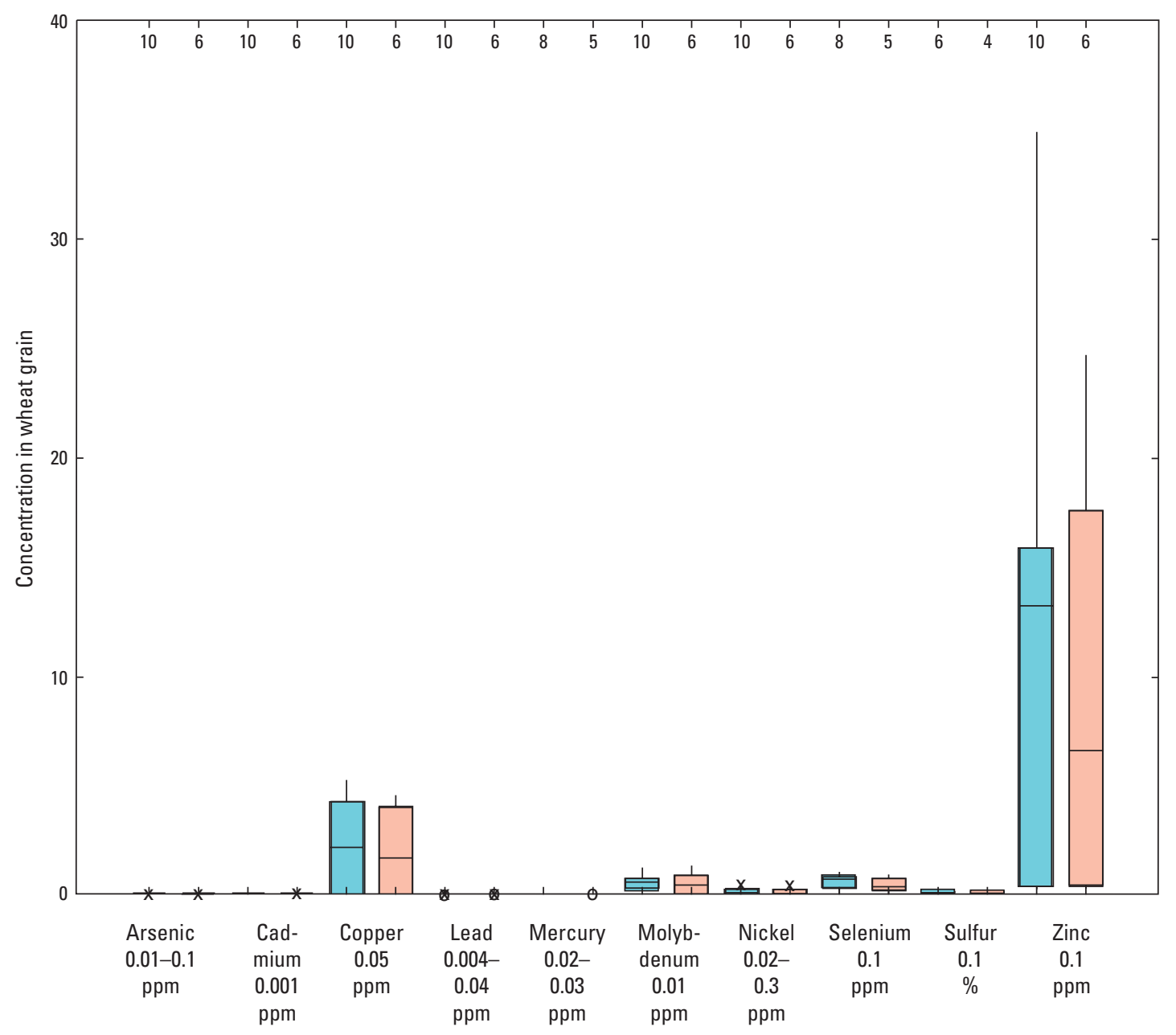

\section{EXPLANATION}

Number of values

Upper detached-Value is $\geq 3$ times the interquartile range beyond upper end of box

$x \quad$ Upper outside-Value is $>1.5$ times and $<3$ times the interquartile range beyond upper end of box

Upper adjacent—Largest value within 1.5 times interquartile range above 75 th percentile

75th percentile

50th percentile

(median)

Interquartile

range

25th percentile

Lower adjacent-Smallest value within 1.5 times interquartile range below 25 th percentile

$x \quad$ Lower outside - Value is $>1.5$ times and $<3$ times the interquartile range beyond lower end of box

0 Lower detached-Value is $\geq 3$ times the interquartile range beyond lower end of box

Arsenic Constituent

0.01-0.1 Minimum reporting level

$\mathrm{ppm} \quad$ Units—ppm, parts per million; \%, percent

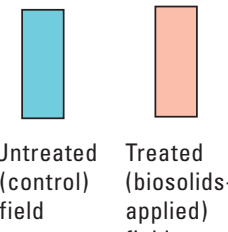

(control) (biosolids-
field

field

Figure 12. Boxplots summarizing concentrations of selected constituents in wheat grain for all untreated-field samples compared to all treated-field samples collected near Deer Trail, Colorado, 2004-2010. 
Table 10. Comparison of concentration of priority parameters in wheat grain from monitoring fields near Deer Trail, Colorado (this study), 2004-2010, with those from other published studies.

[Untreated fields received no biosolids; treated fields received biosolids applied at agronomic loading rates; other published studies had no biosolids applications to fields, and sampling locations are not shown in this report; data from this study are median values for 2004-2010, and sampling locations are shown in figures 2, 10, and 11; U.S., United States; CO, Colorado; CA, California; <, less than; --, not determined; mg/kg, milligrams per kilogram, dry-weight basis]

\begin{tabular}{|c|c|c|c|c|c|c|c|c|}
\hline \multirow[b]{3}{*}{ Parameter } & \multicolumn{4}{|c|}{ Deer Trail study } & \multicolumn{4}{|c|}{ Other published studies } \\
\hline & \multicolumn{2}{|c|}{ Arapahoe County } & \multicolumn{2}{|c|}{ Elbert County } & \multirow[b]{2}{*}{$\begin{array}{c}\text { Great } \\
\text { Plains, } \\
\text { U.S. } \\
\text { (untreated } \\
\text { fields)' }\end{array}$} & \multirow[b]{2}{*}{$\begin{array}{c}\text { Adams } \\
\text { County, CO } \\
\text { (untreated } \\
\text { fields) }^{2}\end{array}$} & \multirow[b]{2}{*}{$\begin{array}{c}\text { San Joaquin } \\
\text { Valley, CA } \\
\text { (untreated }^{\text {fields) }}{ }^{3}\end{array}$} & \multirow[b]{2}{*}{$\begin{array}{c}\text { Western } \\
\text { Canada } \\
\text { (untreated } \\
\text { fields) }^{4}\end{array}$} \\
\hline & $\begin{array}{c}\text { Untreated } \\
\text { (control) } \\
\text { fields }\end{array}$ & $\begin{array}{l}\text { Treated } \\
\text { (biosolids- } \\
\text { applied) } \\
\text { field }\end{array}$ & $\begin{array}{c}\text { Untreated } \\
\text { (control) } \\
\text { fields }\end{array}$ & $\begin{array}{l}\text { Treated } \\
\text { (biosolids- } \\
\text { applied) } \\
\text { field }\end{array}$ & & & & \\
\hline Copper, mg/kg & 1.26 & 2.08 & 2.23 & 1.73 & 3.9 & 5.3 & 4.6 & 4.06 \\
\hline Lead, mg/kg & $<0.01$ & $<0.02$ & $<0.01$ & $<0.01$ & -- & -- & -- & -- \\
\hline Mercury, mg/kg & $<0.03$ & $<0.03$ & $<0.03$ & $<0.03$ & -- & -- & -- & -- \\
\hline Molybdenum, mg/kg & 0.72 & 1.17 & 0.38 & 0.22 & 0.64 & 1.4 & 0.6 & -- \\
\hline
\end{tabular}

${ }^{1}$ Erdman and Gough (1979).

${ }^{2}$ Erdman and Tourtelot (1976).

${ }^{3}$ Severson and others (1991).

${ }^{4}$ Gawalko and others (2001).

\section{Summary}

The U.S. Geological Survey (USGS), in cooperation with Metro Wastewater Reclamation District (Metro District), studied biosolids composition and the effects of biosolids applications on groundwater quality and trace-element concentrations in crops of the Metro District properties near Deer Trail, Colo., during 2004 through 2010. This study was conducted in response to public concern about potential contamination of groundwater and crops from biosolids applications. The objectives of the 2004-2010 study were to (1) evaluate the combined effects of biosolids applications, land use, and natural processes on the chemical composition of groundwater and crops by comparing chemical data to (a) regulatory standards, (b) data from a site where biosolids are not applied (a control site), or (c) earlier data from the same site (trends); (2) monitor the chemical composition of biosolids and compare concentrations with regulatory standards; and (3) characterize the hydrology of the study area, particularly for the water-quality context. The monitoring of each component (such as groundwater or crops) was a standalone study that did not necessarily encompass the entire study area and time period. Priority parameters for each monitoring component included the nine trace elements regulated by Colorado for biosolids (arsenic, cadmium, copper, lead, mercury, molybdenum, nickel, selenium, and zinc). Other constituents and parameters also were analyzed for each monitoring component.

The biosolids in this study resulted from municipal wastewater treatment in Denver, Colo. The biosolids were applied to the soil surface at agronomic loading rates as a fertilizer and soil amendment to farmland near Deer Trail, Colo. The biosolids must meet Federal and State regulatory standards. Biosolids were sampled directly from the Metro District treatment plant in Denver. Dried and ground monthly biosolids samples routinely were analyzed for concentrations of arsenic, cadmium, copper, lead, mercury, molybdenum, nickel, selenium, and zinc as well as many other cation inorganic constituents (including phosphorus) at the chemical laboratories of the USGS. Selected biosolids samples were analyzed for nitrogen (fresh, wet sample) and plutonium isotopes (dried, ground sample) through contract laboratories. Selected biosolids samples (fresh, wet sample) also were analyzed at the USGS for three types of organic wastewater compounds (OWCs) using three different methods: wastewater indicators, pharmaceuticals, and hormones. For a possible biosolids signature to indicate the presence of Metro District biosolids in soil and sediment, the chemical-composition data for biosolids were compared to that for untreated soils and rocks in the study area for inorganic constituents or to reporting levels, data for blanks, and matrix-spike data for OWCs. For a possible biosolids signature to indicate that biosolids had affected groundwater or surface water of the study area, leachate data from biosolids and manure samples 
were evaluated. The leachates were analyzed for nutrients, major ions, trace elements, and selected OWCs at the USGS laboratories in Denver.

All concentrations for the priority parameters in the monthly biosolids samples from the Metro District treatment plant during 2004-2010 were less than the maximum allowable concentrations established by Colorado regulatory standards. The concentration of all nine priority parameters remained relatively consistent throughout the study.

Biosolids likely were the largest source of nitrogen and phosphorus on the Metro District properties. The large nutrient content supports the use of biosolids as a plant fertilizer. There are no published regulatory limits for nitrogen or phosphorus in biosolids.

All the plutonium-isotope data for 2004-2010 were below the minimum detectable concentration with a distribution near zero. There are no published regulatory values for plutonium isotopes in biosolids.

Federal and State biosolids regulations for 2004-2010 did not include any OWCs. Even though biosolids were not regulated for OWCs at this time, these compounds are of interest because of the largely unknown effects of the compounds individually or collectively on the terrestrial ecosystem and the potential for a subset of these compounds to act as a tracer of wastewater occurrence or exposure in the environment. Many OWCs (wastewater indicators, pharmaceuticals, hormones) were detected in the Metro District biosolids samples from 2006 that were analyzed, and many of these compounds were present in the biosolids in substantial concentrations relative to the minimum reporting levels and various surface-water concentrations. The biosolids data indicate that pharmaceuticals and steroid hormones composed much less of the total OWCs content than wastewater indicators in these samples collected in 2006. These findings are similar to published results from other studies.

Results from leachate experiments indicated that inorganic and organic constituents of biosolids can be mobilized in the presence of water. Major ions, nutrients, and trace elements were detected in the various biosolids leachates from the 2005 experiments. Various OWCs also were detected in the biosolids leachates from the 2005 experiments, which included analyses for wastewater indicators and pharmaceuticals. Detections of OWCs in the Metro District biosolids leachates included detergent degradates (nonylphenol), disinfectants (phenol, triclosan), fire retardants (TBEP), fragrances [acetophenone, camphor, HHCB, indole, menthol], pharmaceuticals or their degradates (acetaminophen, carbamazepine, cotinine), plasticizers (DEHP, TBEP), and other wastewater-indicators (benzophenone, p-cresol). It is noteworthy that some hydrophobic compounds were detected in the leachates considering that these compounds are expected to partition primarily to the clay fraction or organic matter in biosolids and not desorb easily into the aqueous phase. A field-aged biosolids sample leached detectable concentrations of 4-nonylphenol, indole, HHCB, and TBEP despite repeated exposure to precipitation and freeze-thaw cycles during the 8 months following land application before the sample was collected from the field surface.

The analytical data for biosolids collected during 2004-2010 were used to refine and expand the biosolids signature for soil and streambed sediments that was reported for the 1999-2003 phase of study. The collected data indicate that elevated concentrations of nutrients (nitrogen, phosphorus), trace elements (bismuth, copper, mercury, silver), benzophenone, biogenic sterols (3-beta-coprostanol, beta-sitosterol, beta-stigmastanol, and cholesterol), detergent degradates (nonylphenol and octylphenol), disinfectants (phenol and triclosan), fire retardants (TBEP), fragrances (3-methyl-1Hindole, acetophenone, AHTN, d-limonene, HHCB, and indole), pharmaceuticals (acetaminophen, diphenhydramine, and miconazole), $\mathrm{p}$-cresol, and plasticizers (bisphenol A, DEHP, TBEP) (table 2) would be the most likely biosolids signature to indicate that soil or streambed sediment contain or have been affected by Metro District biosolids. More biosolids-signature components detected and larger concentration difference from untreated materials and quality-control samples indicate more evidence of biosolids presence or effects.

The 2004-2010 analytical data for filtered biosolids leachates were used to verify and expand the preliminary biosolids signature for aqueous materials (groundwater and surface water) in the vicinity of the Deer Trail biosolidsapplication area that was reported for the 1999-2003 phase of study. The collected data indicate that nutrients (nitrogen, phosphorus), trace elements (antimony, cadmium, cobalt, copper, molybdenum, nickel, selenium, tungsten, vanadium, zinc), benzophenone, detergent degradates (nonylphenol), disinfectants (phenol, triclosan), fire retardants (TBEP), fragrances (3-methyl-1H-indole, acetophenone, camphor, HHCB, indole, menthol), pharmaceuticals or their degradates (acetaminophen, carbamazepine, cotinine), p-cresol, and plasticizers (bisphenol A, DEHP, TBEP), would be the most likely biosolids signature for groundwater and surface water in the study area. As was true for the solid-materials biosolids signature, more biosolids-signature components detected and larger concentration differences from baseline and blank-sample concentrations indicate more evidence of biosolids presence or effects for groundwater or surface water. Inevitably, consumer-product composition, availability, and use will change over time. These changes in consumer products, as well as changes to treatment processes at the wastewater treatment plant, could change the biosolidsproduct chemical composition and associated leachate composition over time and affect the utility of these components in indicating biosolids presence or effects. The preliminary data indicate that additional studies would be needed to determine which chemicals are representative of cow-manure leachate or more indicative of biosolids leachate.

Groundwater routinely was monitored for hydrology and chemistry at USGS monitoring wells. Vertical recharge 
was evaluated at two recharge-evaluation areas by using water-level data from wells at various depths at the same site in conjunction with precipitation data. Water levels (depth to groundwater) were measured monthly at the USGS monitoring wells in the study area, as well as continuously at several sites, to provide a hydrologic context for water-quality monitoring during 2004-2010. Water samples usually were collected quarterly from five alluvial-aquifer wells on the Metro District properties, and water samples were collected annually from the shallowest zone (A) of the bedrock aquifer at two locations that are important to alluvial/bedrock groundwater interactions, the recharge-evaluation areas. Groundwater samples were analyzed for many parameters, including the priority parameters identified by the stakeholders (nitrate, arsenic, cadmium, copper, chromium, lead, mercury, molybdenum, nickel, selenium, and zinc). Samples were analyzed routinely for physical properties, dissolved major ions, dissolved and total nutrients, and dissolved trace elements by the USGS.

Samples from the five routinely sampled alluvial-aquifer wells also were analyzed for dissolved OWCs (wastewater indicators, only) once in 2005.

The primary water-supply aquifer in the study area is the Laramie-Fox Hills aquifer, and multiple alluvial aquifers also are present in the study area. The alluvial aquifers are associated with the surficial drainage network and contain water of variable quality, are of limited extent, and generally yield little water. Short segments of some of the streams are intermittent, but in general, the streams are ephemeral and flow only after storms. Groundwater levels fluctuated spatially and temporally during 2004-2010. Depth to water below land surface in the bedrock-aquifer monitoring wells ranged from about 2.1 feet (ft) to about $152 \mathrm{ft}$. Depth to water below land surface in the alluvial-aquifer monitoring wells ranged from about $3.5 \mathrm{ft}$ to about $21 \mathrm{ft}$. Water levels fluctuated the least during winter and the most during summer. Data for 2004-2010 from the recharge-evaluation area closest to the biosolids-application area indicate that the vertical hydraulic gradient was nearly always favorable for the shallow, sandy zone of the bedrock aquifer to recharge (discharge to) the alluvial aquifer and the deeper zone of the bedrock aquifer. Therefore, the shallow zone of the bedrock aquifer at this location was not very susceptible to surficial contamination, such as that from biosolids applications or animal manure. Conversely, data for 2004-2010 from the recharge-evaluation area that is farther downstream and downgradient from the biosolids-application area indicate that the vertical hydraulic gradient was sometimes favorable for the shallow zone of the bedrock aquifer to recharge the alluvial aquifer and sometimes favorable for the alluvial aquifer to recharge the shallow zone of the bedrock aquifer. The shallow zone of the bedrock aquifer at this location was much more susceptible to surficial contamination, such as that from biosolids applications or animal manure. The land uses in close proximity to this more downstream recharge-evaluation area, however, are likely to have a larger effect on groundwater quality than the biosolids applications that are more than 4 miles upstream.

The chemical effects of biosolids on groundwater quality could be inorganic (nutrients and trace elements) or organic (natural and synthetic carbon compounds, including OWCs). Most of the priority parameters, however, are part of natural aquifer geochemical composition and variation. In order to state with confidence that groundwater composition for the priority parameters is affected by biosolids, the composition or variation must significantly exceed the natural aquifer geochemical composition and variation. Multiple approaches were used to discern possible biosolids effects on water quality in the study area. Water quality was evaluated by sampling different sites at the same time and by sampling the same sites at different times. Although concentrations of dissolved nitrite plus nitrate as nitrogen, copper, nickel, selenium, and zinc had large ranges in concentration, the median concentrations of these constituents and the other priority parameters in all groundwater samples from the study area were small (near or less than minimum reporting levels). Although the inorganic constituent concentrations were relatively large in samples from well D6, the concentrations of OWCs were not correspondingly large in the D6 samples. Concentrations of OWCs in the samples collected in 2005 from all five monitoring wells (including those from well D6) were less than the minimum reporting levels with only a few detections. A comparison of the OWCs data for the groundwater samples with those for the biosolids samples indicates that some of the OWCs detected in the groundwater samples could have anthropogenic sources that are not biosolids. Concentrations of priority parameters in groundwater near Deer Trail varied spatially (different concentrations at different locations at the same time) and temporally (different concentrations at the same locations at different times throughout 2004-2010). Although laboratory quality assurance indicated periods of analytical bias (positive or negative) that could have affected the 2004-2010 data, no sustained or substantial bias was apparent in the laboratory data or other field data. In general, sample variability was negligible compared to aquifer variation. A comparison of individual concentration values indicates that concentrations of priority parameters generally were less than Colorado regulatory limits for groundwater. All concentrations of dissolved cadmium, chromium, copper, lead, mercury, nickel, and zinc in the samples from 2004-2010 met the Colorado standards. The comparison of individual concentration values also indicates that concentrations of some priority parameters (dissolved nitrate, arsenic, and selenium) in samples from some wells exceeded the Colorado standards. Some groundwater samples from the study area during 2004-2010 also exceeded Colorado standards for chloride, sulfate, total dissolved solids, boron, iron, manganese, and uranium. The concentrations of the 12 regulated OWCs in the samples collected in 2005 from the five alluvial-aquifer wells all met the Colorado standards, although the laboratory reported 
concentrations for benzo[a]pyrene as less than the MRL, which was higher than the Colorado standard.

A statistical evaluation of selected water-quality data for selected wells indicates that groundwater concentrations for 2004-2010 were significantly (alpha $=0.05$ ) higher than the lowest regulatory standard for dissolved nitrate (one well), selenium (one well), and uranium (two wells). Concentrations of dissolved arsenic, cadmium, chromium, copper, lead, mercury, molybdenum, nickel, silver, and zinc in groundwater samples from the five routinely sampled alluvial-aquifer wells did not significantly (alpha $=0.05$ ) exceed Colorado regulatory standards. For the most part, the comparisons of 90-percent prediction intervals for the 2004-2010 data with the Colorado regulatory standards reinforce the findings from the statistical evaluation.

Concentrations of dissolved arsenic, cadmium, chromium, copper, lead, mercury, nickel, silver, tungsten, and zinc data had no significant (alpha $=0.05)$ upward trends. Concentrations of dissolved nitrate (three wells), molybdenum (one well), selenium (two wells), and uranium (one well) in shallow groundwater had significant $($ alpha $=0.05)$ upward trends in some parts of the study area. Biosolids could be contributing to the increasing nitrate concentrations by providing more nitrogen to soil and groundwater than can be used by vegetation or microorganisms, however, the upward trends in nitrate concentration in the study area may not be caused solely by biosolids applications. The slightly larger number of significant upward trends in the 2004-2010 data compared to the 1999-2003 data may not indicate gross contamination in the study area, but could relate to biosolids applications in that there has been more time for biosolidsaffected water to recharge the aquifers. Alternatively, the change in water-quality trends could be related to changes in weather (wet or dry cycles) or recharge patterns.

A comparison of study-area groundwater concentrations with a preliminary aqueous biosolids signature can indicate whether the groundwater has recharged through treated (biosolids-applied) fields. More biosolids-signature components detected indicates stronger evidence that groundwater could have been affected by biosolids applications - even if all concentrations are below the regulated levels. All 29 of the biosolids-signature components were not detected in any of the groundwater samples from the study area. Of the 24 biosolids-signature components that were analytes for the groundwater samples in this study, 9 inorganic components and 4 organic components were detected at biosolidssignature levels in one or more groundwater samples. The biosolids-signature components were not always present at large concentrations in the samples from the study area, and the larger concentrations of these components in the samples were not always from the same wells. The biosolids-signature results indicate that the aquifers intercepted by the five routinely sampled wells (especially at wells D25 and DTX1) likely have received some recharge through treated fields or biosolids-affected ponds.
The strength of the aqueous biosolids signature is a better indicator than exceedance of standards or upward trends for biosolids effects on study-area groundwater. Many of the inorganic constituents in the groundwater have sources besides biosolids (such as soil and rock) in the study area, and the concentrations of these inorganic constituents are subject to advection and reaction processes in the aquifers that can change the concentrations over time. Despite the generally poor quality of groundwater from well D6, the biosolids signature was weak in samples from D6, and most of the exceedances were from concentrated solutes of geologic origin and were not related to biosolids applications. Given that biosolids applications are a likely source of the nitrogen in the groundwater from well D6, the concentrated solutes in the groundwater from well D6 might be obscuring or interfering with the biosolids signature in samples from this well. The groundwater at well D6 likely is affected by biosolids applications to the study area, and the USGS data indicate some adverse effects, such as large and significantly increasing nitrate concentrations. The biosolids signature in groundwater from well D17 is a little stronger than that from well D6, although groundwater from well D17 naturally has relatively small concentrations of most inorganic constituents. The groundwater from well D17 likely is affected by biosolids applications to the study area, but the USGS data indicate few adverse effects. The strongest biosolids signature was in groundwater samples from well D25; the groundwater from well D25 likely is affected by biosolids applications to the study area, but the USGS data indicate few adverse effects. The biosolids signature in groundwater from well DTX1 was strong and was just a little weaker than that from well D25; the groundwater from well DTX1 likely is affected by biosolids applications to the study area, but the USGS data indicate few adverse effects. The biosolids signature in groundwater from well DTX2 was the weakest of those from the five wells evaluated; the groundwater from well DTX2 possibly is affected by biosolids applications to the study area, but the USGS data indicate few (if any) adverse effects. Little evidence of a (preliminary) cow-manure signature was discernible in the 2004-2010 groundwater samples from the selected wells, and this preliminary manure signature was not definitive in distinguishing biosolids sources or effects from cow-manure sources or effects. The comparison of the biosolids-signature results with the (preliminary) cow-manure signature and other water-quality indicators such as regulatory standards and upward trends indicates that (1) the biosolids-signature approach can be useful in differentiating effects, (2) the use of multiple evaluation approaches increases understanding of complex water-quality issues, (3) biosolids-affected groundwater in the study area can have poor to good water quality, and (4) water-quality problems can result from natural sources and processes in the study area, as well as from biosolids applications.

Crops were monitored for concentrations of the priority parameters in mature grain at two monitoring sites during 2004-2010. Each site consisted of two untreated (control) 
fields that did not receive biosolids applications and one treated (biosolids-applied) field, all of which were farmed at the same time and in the same way. Neither the treated fields nor the untreated fields were irrigated. The crop at the monitoring sites usually was a variety of hard red winter wheat, and the farming practice usually included a crop/ fallow rotation. The cleaned, dried, and ground samples were analyzed by the USGS for priority parameters: arsenic, cadmium, copper, lead, mercury, molybdenum, nickel, selenium, and zinc. Selected samples also were analyzed for sulfur. Little difference is discernible in the 2004-2010 wheat-grain data between the grain from the treated fields and the grain from the untreated fields. The differences shown could be the product of laboratory variability rather than biosolids effect. The statistical evaluation of the five paired wheat-grain samples did not indicate any evidence $(\mathrm{p}>0.18)$ that biosolids applications significantly (alpha $=0.05$ or 0.10 ) increased concentration of any of the priority parameters in wheat grain. The wheat-grain data produced during this study were compared with composition data found in the literature for similar winter wheat where no biosolids were applied. For all elements in common among the data sets, the wheat from the study area had similar concentrations to those from the other localities in North America. Therefore, the data for the limited crop samples collected from the study area during 2004-2010 indicate that biosolids applications are not increasing the concentrations of arsenic, cadmium, copper, lead, mercury, molybdenum, nickel, selenium, sulfur, and zinc in mature wheat grain.

\section{Acknowledgments}

The USGS thanks landowners for allowing access to their properties for data collection. The USGS especially thanks the landowners for allowing USGS instrument or well installations on their property.

\section{References Cited}

Adeyinka, J.S., and Mustapha, R., 2005, An assessment of pollution from agrochemical application: International Journal of Environmental Studies, v. 62, no. 3, p. 323-327.

Andaluri, G., Suri, R.P., and Kumar, K., 2012, Occurrence of estrogen hormones in biosolids, animal manure and mushroom compost: Environmental Monitoring and Assessment, v. 184, no.2, p. 1197-1205 (Available at http://www.springerlink.com/content/r1tk778044k80hjq/fulltext.pdf)
Barnes, K.K., Kolpin, D.W., Focazio, M.J., Furlong, E.T., Meyer, M.T., Zaugg, S.D., Haack, S.K., Barber, L.B., and Thurman, E.M., 2008, Water-quality data for pharmaceuticals and other organic wastewater contaminants in ground water and in untreated drinking water sources in the United States, 2000-01: U.S. Geological Survey Open-File Report 2008-1293, 7 p. plus tables. (Available at $h t t p: / /$ pubs.usgs.gov/of/2008/1293/)

Barnes, K.K., Kolpin, D.W., Furlong, E.T., Zaugg, S.D., Meyer, M.T., and Barber, L.B., 2008, A national reconnaissance of pharmaceuticals and other organic wastewater contaminants in the United States-Ground water: Science of the Total Environment, v. 402, nos. 2-3, p. 192-200. (Available at http://www.sciencedirect.com/science/article/ pii/S0048969708004671)

Barnes, K.K., Kolpin, D.W., Meyer, M.T., Thurman, E.M., Furlong, E.T., Zaugg, S.D., and Barber, L.B., 2002, Waterquality data for pharmaceuticals and other organic wastewater contaminants in U.S. streams, 1999-2000: U.S. Geological Survey Open-File Report 2002-94, 7 p. plus tables. (Available online at http://toxics.usgs.gov/pubs/ OFR-02-94/)

Burkhardt, M.R., Zaugg, S.D., Smith, S.G., and ReVello, R.C., 2006, Determination of wastewater compounds in sediment and soil by pressurized solvent extraction, solid-phase extraction, and capillary-column gas chromatography/ mass spectrometry: U.S. Geological Survey Techniques and Methods, book 5, chap. B2, 40 p. (Available at http://pubs. usgs.gov/tm/2006/tm5b2/pdf/TM5-B2_508.pdf)

Cahill, J.D., Furlong, E.T., Burkhardt, M.R., Kolpin, D.W., and Anderson, L.G., 2004, Determination of pharmaceutical compounds in surface- and ground-water samples by solid-phase extraction and high-performance liquid chromatography-electrospray ionization mass spectrometry: Journal of Chromatography A, v. 1041, no. 1-2, p. 171-180.

Childress, C.J.O., Foreman, W.T., Connor, B.F., and Maloney, T.J, 1999, New reporting procedures based on longterm method detection levels and some considerations for interpretations of water-quality data provided by the U.S. Geological Survey National Water Quality Laboratory: U.S. Geological Survey Open-File Report 99-193, 19 p. (Available at http://pubs.er.usgs.gov/publication/ofr99193)

Choe, Suck-Young, Kim, So-Jung, Kim, Hae-Gyoung, Lee, J.H., Choi, Younghee, Lee, Hun, Kim, Yangho, 2003, Evaluation of estrogenicity of major heavy metals: Science of The Total Environment, v. 312, nos. 1-3, p. 15-21. (Available at http://www.sciencedirect.com/ science/article/pii/S0048969703001906) 
Colorado Department of Public Health and Environment, 2003, Biosolids regulation: 5CCR 1002-64, April 14, 2003 and subsequent revisions, 54 p., accessed July 18, 2012, at $h t t p: / / w w w . c d p h e . s t a t e . c o . u s / w q / P e r m i t s U n i t /$ biosolidsindex.html.

Colorado Department of Public Health and Environment, 2009, Basic standards for groundwater: 5CCR 1002-41, October 13, 2009, 64 p., accessed July 18, 2012, at http://www.cdphe.state.co.us/regulations/wqccregs/100241 wqccbasicstandardsforgroundwater.pdf.

Crock, J.G., Smith, D.B., and Yager, T.J.B., 2009, Analytical results for agricultural soil samples from a monitoring program near Deer Trail, Colorado (U.S.A.): U.S. Geological Survey Open-File Report 2009-1111, 147 p. (Available at $h t t p: / / p u b s . u s g s . g o v / o f / 2009 / 1111 /)$

Crock, J.G., Smith, D.B., Yager, T.J.B., Berry, C.J., and Adams, M.G., 2008, Analytical results for municipal biosolids samples from a monitoring program near Deer Trail, Colorado (U.S.A.), 2007: U.S. Geological Survey OpenFile Report 2008-1358, 35 p. (Available at http://pubs.usgs. gov/of/2008/1358/)

Crock, J.G., Smith, D.B., Yager, T.J.B., Berry, C.J., and Adams, M.G., 2009, Analytical results for municipal biosolids samples from a monitoring program near Deer Trail, Colorado (U.S.A.), 2008: U.S. Geological Survey Open-File Report 2009-1090, 29 p. (Available at http://pubs.usgs.gov/of/2009/1090/)

Crock, J.G., Smith, D.B., Yager, T.J.B., Berry, C.J., and Adams, M.G., 2010, Analytical results for municipal biosolids samples from a monitoring program near Deer Trail, Colorado (U.S.A.), 2009: U.S. Geological Survey Open-File Report 2010-1162, 23 p. (Available at http://pubs.usgs.gov/of/2010/1162/)

Crock, J.G., Smith, D.B., Yager, T.J.B., Berry, C.J., and Adams, M.G., 2011, Analytical results for municipal biosolids samples from a monitoring program near Deer Trail, Colorado (U.S.A.), 2010: U.S. Geological Survey Open-File Report 2011-1146, 24 p. (Available at http://pubs.usgs.gov/of/2011/1146/)

Crock, J.G., Smith, D.B., Yager, T.J.B., Brown, Z.A., and Adams, M.G., 2008, Analytical results for municipal biosolids samples from a monitoring program near Deer Trail, Colorado (U.S.A.), 1999 through 2006: U.S. Geological Survey Open-File Report 2008-1172, 67 p. (Available at http://pubs.usgs.gov/of/2008/1172/)

Drever, J.I., 1988, The geochemistry of natural waters ( 2 d ed.): New Jersey, Prentice-Hall, p. 328-329.
Drew, L.J., Schuenemeyer, J.H., and Bawiec, W.J., 1979, Petroleum exhaustion maps of the Cretaceous "D-J" sandstone stratigraphic interval of the Denver Basin: U.S. Geological Survey Miscellaneous Investigations Series Map I-1138, scale 1:200,000, sheet 2.

Erdman, J.A., and Gough, L.P., 1979, Mineral composition of wheat from coal-mine spoils and farms in the Northern Great Plains, USA, in Wali, M.K., ed., Ecology and coal resource development: New York, Pergamon Press, p. $878-886$.

Erdman, J.A., and Tourtelot, H.A., 1976, Denver liquid sewage sludge-Its agricultural benefits and its effect on the metal composition of wheat grown at the Watkins test site, Adams County, Colorado: U.S. Geological Survey Open-File Report 76-810, 29 p.

Fenech, C., Rock, L., Nolan, K., Tobin, J., and Morrissey, A., 2012, The potential for a suite of isotope and chemical markers to differentiate sources of nitrate contamination-A review: Water Research, v. 46, p. 2024-2041.

Fenneman, N.M., 1931, Physiography of the western United States: New York, McGraw-Hill, 534 p.

Fishman, M.J., ed., 1993, Methods of analysis by the U.S. Geological Survey National Water Quality LaboratoryDetermination of inorganic and organic constituents in water and fluvial sediments: U.S. Geological Survey OpenFile Report 93-125, $217 \mathrm{p}$.

Fishman, M.J., and Friedman, L.C., ed., 1989, Methods for determination of inorganic and organic substances in water and fluvial sediments: U.S. Geological Survey Techniques of Water-Resources Investigations, book 5, chap. A1, 545 p.

Furlong, E.T., Werner, S.L., Anderson, B.D., and Cahill, J.D., 2008, Determination of human-health pharmaceuticals in filtered water by chemically modified styrenedivinylbenzene resin-based solid-phase extraction and highperformance liquid chromatography/mass spectrometry: U.S. Geological Survey Techniques and Methods, book 5, chap. B5, 54 p. (Available at $h t t p: / / p u b s . u s g s . g o v / t m / t m 5 b 5 /$ pdf/tm-5-b5_508.pdf)

Gawalko, E.J., Garrett, R.G., and Nowicki, T.W., 2001, Trace elements in Western Canadian Hard Red Spring wheat (Triticum aestivum L.) - Levels and quality assurance: Journal of Association of Official Analytical Chemists International, v. 84, no. 6, p. 1953-1963.

Hageman, P.L., 2007, U.S. Geological Survey field leach test for assessing water reactivity and leaching potential of mine-wastes, soils, and other geologic and environmental materials: U.S. Geological Survey Techniques and Methods, book 5, chap. D3, 14 p. (Available at http://pubs.usgs.gov/ tm/2007/05D03/) 
Helsel, D.R., 2005, Nondetects and data analysis: Hoboken, New Jersey, Wiley Interscience, 250 p.

Helsel, D.R., and Hirsch, R.M., 2002, Statistical methods in water resources: U.S. Geological Survey Techniques of Water-Resources Investigations, book 4, chap. A3, 510 p. (Available at http://pubs.usgs.gov/twri/twri4a3/)

Iavicoli, Ivo, Fontana, Luca, and Bergamaschi, Antonio, 2009, The effects of metals as endocrine disruptors: Journal of Toxicology and Environmental Health, Part B. Critical Reviews, v. 12 , no. 3, p. 206-223.

Kinney, C.A., Furlong, E.T., Zaugg, S.D., Burkhardt, M.R., Werner, S.L., Cahill, J.D., and Jorgensen, G.R., 2006, Survey of organic wastewater contaminants in biosolids destined for land application: Environmental Science \& Technology, v. 40, no. 23, p. 7207-7215.

Kolpin, D.W., Furlong, E.T., Meyer, M.T., Thurman, E.M., Zaugg, S.D., Barber, L.B., and Buxton, H.T., 2002, Pharmaceuticals, hormones, and other organic wastewater contaminants in U.S. streams, 1999-2000-A national reconnaissance: Environmental Science \& Technology, v. 36 , no. 6 , p. 1202-1211.

Larsen, L.S., Baber, T.G., Wesswick, E.L., McCoy, D.E., and Harman, J.B., 1966, Soil survey of Elbert County, Colorado, Eastern part: U.S. Department of Agriculture Soil Conservation Service Soil Survey series 1960, no. 31, 79 p.

Larsen, L.S., and Brown, J.B., 1971, Soil survey of Arapahoe County, Colorado: U.S. Department of Agriculture Soil Conservation Service Soil Survey series, 78 p.

Lee, K.E., Barber, L.B., Furlong, E.T., Cahill, J.D., Kolpin, D.W., Meyer, M.T., and Zaugg, S.D., 2004, Presence and distribution of organic wastewater compounds in wastewater, surface, ground, and drinking waters, Minnesota, 2000-02: U.S. Geological Survey Scientific Investigation Report 2004-5138, 47 p.

Lee, K.E., Langer, S.K., Barber, L.B., Writer, J.H., Ferrey, M.L., Schoenfuss, H.L., Furlong, E.T., Foreman, W.T., Gray, J.L., ReVello, R.C., Martinovic, D., Woodruff, O.P., Keefe, S.H., Brown, G.K., Taylor, H.E., Ferrer, I., and Thurman, E.M., 2011, Endocrine active chemicals, pharmaceuticals, and other chemicals of concern in surface water, wastewater-treatment plant effluent, and bed sediment, and biological characteristics in selected streams, Minnesotadesign, methods, and data, 2009: U.S. Geological Survey Data Series 575, 54 p., with appendixes. (Available at http://pubs.usgs.gov/ds/575/)

Lorenzen, A., Hendel, J.G., Conn, K.L., Bittman, S., Kwabiah, A.B., Lazarovitz, G., Masse, D., McAllister, T.A., and Topp, E., 2004, Survey of hormone activities in municipal biosolids and animal manures: Environmental Toxicology, v. 19 , no. 3, p. 216-225.
Major, T.J., Robson, S.G., Romero, J.C., and Zawistowski, Stanley, 1983, Hydrogeologic data from parts of the Denver Basin, Colorado: U.S. Geological Survey Open-File Report 83-274, 425 p.

McCurdy, D.E., Garbarino, J.R., and Mullin, A.H., 2008, Interpreting and reporting radiological water-quality data: U.S. Geological Survey Techniques and Methods, book 5, chap. B6, 33 p. (Available at http://pubs.usgs.gov/ tm/05b06/)

Muhs, D.R., Aleinikoff, J.N., Stafford, T.W., Jr., Kihl, Rolf, Been, Josh, Mahan, S.A., and Cowherd, Scott, 1999, Late Quaternary loess in northeastern Colorado, Part I-Age and paleoclimatic significance: Geological Society of America Bulletin, v. 111, no. 12, p. 1861-1875. (Available at http://esp.cr.usgs.gov/info/eolian/Muhs1999GSABull.pdf)

Nakada, Norihide; Kiri, Kentaro; Shinohara, Hiroyuki; Harada, Arata; Kuroda, Keisuke; Takizawa, Satoshi; and Takada, Hideshige, 2008, Evaluation of pharmaceuticals and personal care products as water-soluble molecular markers of sewage: Environmental Science \& Technology, v. 42 , no. 17 , p. 6347-6353.

Pais, Istvan, and Jones, J.B. Jr., 1997, The handbook of trace elements: Boca Raton, Fla., St. Lucie Press, 223 p.

Reheis, M.C., Honke, Jeff, Lamothe, Paul, and Fisher, Eric, 2009, Description and analytical results for deposited dust samples from a two-year monitoring program near Deer Trail, Colorado, USA, 2006-2007: U.S. Geological Survey Open-File Report 2008-1361, 12 p. (Available at http://pubs.usgs.gov/of/2008/1361/)

Robson, S.G., and Banta, E.R, 1995, Ground water atlas of the United States, segment 2, Arizona, Colorado, New Mexico, Utah: U.S. Geological Survey Hydrologic Investigations Atlas 730-C, p. C20-C22.

Robson, S.G., Wacinski, Andrew, Zawistowski, Stanley, and Romero, J.C., 1981, Geologic structure, hydrology, and water quality of the Laramie-Fox Hills aquifer in the Denver Basin, Colorado: U.S. Geological Survey Hydrologic Investigations Atlas Map HA-650, scale 1:500,000, sheet 1 .

Rounds, S.A., Doyle, M.C., Edwards, P.M., and Furlong, E.T., 2009, Reconnaissance of pharmaceutical chemicals in urban streams of the Tualatin River basin, Oregon, 2002: U.S. Geological Survey Scientific Investigations Report 2009-5119, 22 p.

Sando, S.K., Furlong, E.T., Gray, J.L., Meyer, M.T., and Bartholomay, R.C., 2005, Occurrence of organic wastewater compounds in wastewater effluent and the Big Sioux River in the Upper Big Sioux River Basin, South Dakota, 2003-2004: U.S. Geological Survey Scientific Investigations Report 2005-5249, 108 p. 
Sando, S.K., Furlong, E.T., Gray, J.L., and Meyer, M.T., 2006, Occurrence of organic wastewater compounds in drinking water, wastewater effluent, and the Big Sioux River in or near Sioux Falls, South Dakota, 2001-2004: U.S. Geological Survey Scientific Investigations Report 2006-5118, $178 \mathrm{p}$.

Seaber, P.R., Kapinos, F.P., and Knapp, G.L., 1987, Hydrologic unit maps: U.S. Geological Survey Water-Supply Paper 2294, 63 p.

Severson, R.C., Gough, L.P., Crock, J.G., Fey, D.L., Hageman, P.L., Love, A.H., and Peacock, T.R., 1991, Uptake and physiological antagonism of selenium and sulfur in alfalfa and wheat under field conditions, San Joaquin Valley, California: U.S. Geological Survey Open-File Report 91-16, 42 p.

Sharps, J.A., 1980, Geologic map of the Limon 1 x 2 quadrangle, Colorado and Kansas: U.S. Geological Survey Miscellaneous Investigations Series Map I-1250, scale 1:250,000, sheet 1 .

Sikka, S.C., and Wang, Run, 2008, Endocrine disruptors and estrogenic effects on male reproductive axis: Asian Journal of Andrology, v. 10, p. 134-145.

Stevens, M.R., Yager, T.J.B., Smith, D.B., and Crock, J.G., 2003, Biosolids, soils, ground-water, and streambedsediment data for a biosolids-application area near Deer Trail, Colorado: U.S. Geological Survey Open-File Report 02-51, 118 p. (Available at http://pubs.water.usgs. gov/ofr02051/)

Tjandraatmadja, G., Pollard, C., Sheedy, C., and Gozukara, Y., 2010, Sources of contaminants in domestic wastewater: nutrients and additional elements from household products: CSIRO Water for a Healthy Country Flagship Report series, Australia, 103 p., accessed July 19, 2012, at http://www.clw. csiro.au/publications/waterforahealthycountry/2010/wfhccontaminants-domestic-wastewater.pdf.

U.S. Environmental Protection Agency, 1993 (and subsequent revisions), Part 503-Standards for the use or disposal of sewage sludge: Code of Federal Regulations Title 40, vol. 27, 40CFR503, p. 820-852, accessed July 19, 2012, at $h t t p: / / w w w . a c c e s s . g p o . g o v /$ nara/cfr/ waisidx_02/40cfr503_02.html.

U.S. Environmental Protection Agency, 2009, Biosolids: Targeted national sewage sludge survey sampling and analysis technical report, EPA 822-R-08-016, 79 p. (Available at http://water.epa.gov/scitech/wastetech/ biosolids/index.cfm)

U.S. Geological Survey, 1974, Hydrologic unit map-1974, State of Colorado: U.S. Geological Survey Hydrologic Unit Map 1974, scale 1:500,000, 1 sheet.
U.S. Geological Survey, 1980, Land use and land cover, 1975, Limon, Colorado; Kansas: U.S. Geological Survey Land Use Series L-191, scale 1:250,000, 1 sheet.

U.S. Geological Survey, variously dated, National field manual for the collection of water-quality data: U.S. Geological Survey Techniques of Water-Resources Investigations, book 9, chaps. A1-A9. (Available at http://pubs.water.usgs. gov/twri9A)

Vajda, A.M., Barber, L.B., Gray, J.L., Lopez, E.M., Woodling, J.D., and Norris, D.O., 2008, Reproductive disruption in fish downstream from an estrogenic wastewater effluent: Environmental Science \& Technology, v. 42, no. 9, p. 3407-3414.

Verplanck, P.L., Murphy, S.F., and Barber, L.B., 2003, Water quality of the Boulder Creek Watershed, Colorado: U.S. Geological Survey Fact Sheet 043-03.

Yager, T.J.B., 2013 [in press], Water quality at a biosolidsapplication area near Deer Trail, Colorado, 1993-1999: U.S. Geological Survey Scientific Investigations Report 2013-5074.

Yager, T.J.B., and Arnold, L.R., 2003, Hydrogeology of a biosolids-application site near Deer Trail, Colorado, 199399: U.S. Geological Survey Water-Resources Investigations Report 03-4209, 90 p. (Available at http://pubs.water.usgs. gov/wri034209/)

Yager, T.J.B., and McMahon, P.B., 2012, Preliminary assessment of sources of nitrogen in groundwater at a biosolidsapplication area near Deer Trail, Colorado, 2005: U.S. Geological Survey Scientific Investigations Report 2012-5056, 30 p. (Available at http://pubs.usgs.gov/sir/2012/5056/)

Yager, T.J.B., Smith, D.B., and Crock, J.G., 2004a, Biosolids, soil, crop, ground-water, and stream-bed-sediment data for a biosolids-application area near Deer Trail, Colorado, 2001: U.S. Geological Survey Open-File Report 2004-1388, 69 p. (Available at http://pubs.usgs.gov/of/2004/1388/)

Yager, T.J.B., Smith, D.B., and Crock, J.G., 2004b, Biosolids, soil, crop, ground-water, and stream-bed-sediment data for a biosolids-application area near Deer Trail, Colorado, 2002-2003: U.S. Geological Survey Open-File Report 2004-1404, 90 p. (Available at http://pubs.usgs.gov/ of/2004/1404/)

Yager, T.J.B., Smith, D.B., and Crock, J.G., 2004c, Effects of surface applications of biosolids on soil, crops, ground water, and streambed sediment near Deer Trail, Colorado, 1999-2003: U.S. Geological Survey Scientific Investigations Report 2004-5289, 93 p. (Available at http://pubs. usgs.gov/sir/2004/5289) 
Yager, T.J.B., Smith, D.B., and Crock, J.G., 2009, Biosolids, crop, and ground-water data for a biosolids-application area near Deer Trail, Colorado, 2004 through 2006: U.S. Geological Survey Data Series 379, 57 p. (Available at http://pubs.usgs.gov/ds/379)

Yager, T.J.B., Smith, D.B., and Crock, J.G., 2011, Biosolids, crop, and groundwater data for a biosolids-application area near Deer Trail, Colorado, 2007 and 2008: U.S. Geological Survey Data Series 589, 53 p. (Available at http://pubs.usgs. gov/ds/589)

Yager, T.J.B., Smith, D.B., and Crock, J.G., 2012, Biosolids, crop, and groundwater data for a biosolids-application area near Deer Trail, Colorado, 2009 and 2010: U.S. Geological Survey Data Series 664, 46 p. (Available at http://pubs.usgs. gov/ds/664)

Yager, T.J.B., Smith, D.B., Crock, J.G., and Stevens, M.R., 2004, Biosolids, soil, crop, ground-water, and streambedsediment data for a biosolids-application area near Deer Trail, Colorado, 2000: U.S. Geological Survey Open-File Report 03-400, 90 p. (Available at http://pubs.water.usgs. gov/ofro3-400)

Zaugg, S.D., Smith, S.G., and Schroeder, M.P., 2006, Determination of wastewater compounds in whole water by continuous liquid-liquid extraction and capillary-column gas chromatography/mass spectrometry: U.S. Geological Survey Techniques and Methods, book 5, chap. B4, 30 p. (Available at http://pubs.usgs.gov/tm/2006/05B0/)

Zaugg, S.D., Smith, S.G., Schroeder, M.P., Barber, L.B., and Burkhardt, M.R., 2002 [2007 rev.], Methods of analysis by the U.S. Geological Survey National Water Quality Laboratory-Determination of wastewater compounds by polystyrene-divinylbenzene solid-phase extraction and capillary-column gas chromatography/mass spectrometry: U.S. Geological Survey Water-Resources Investigations Report 01-4186, 37 p. (Available at http://pubs.usgs.gov/ wri/wri014186) 
Appendixes 
Appendix 1. Metro Wastewater Reclamation District biosolids-application areas near Deer Trail, Colorado.

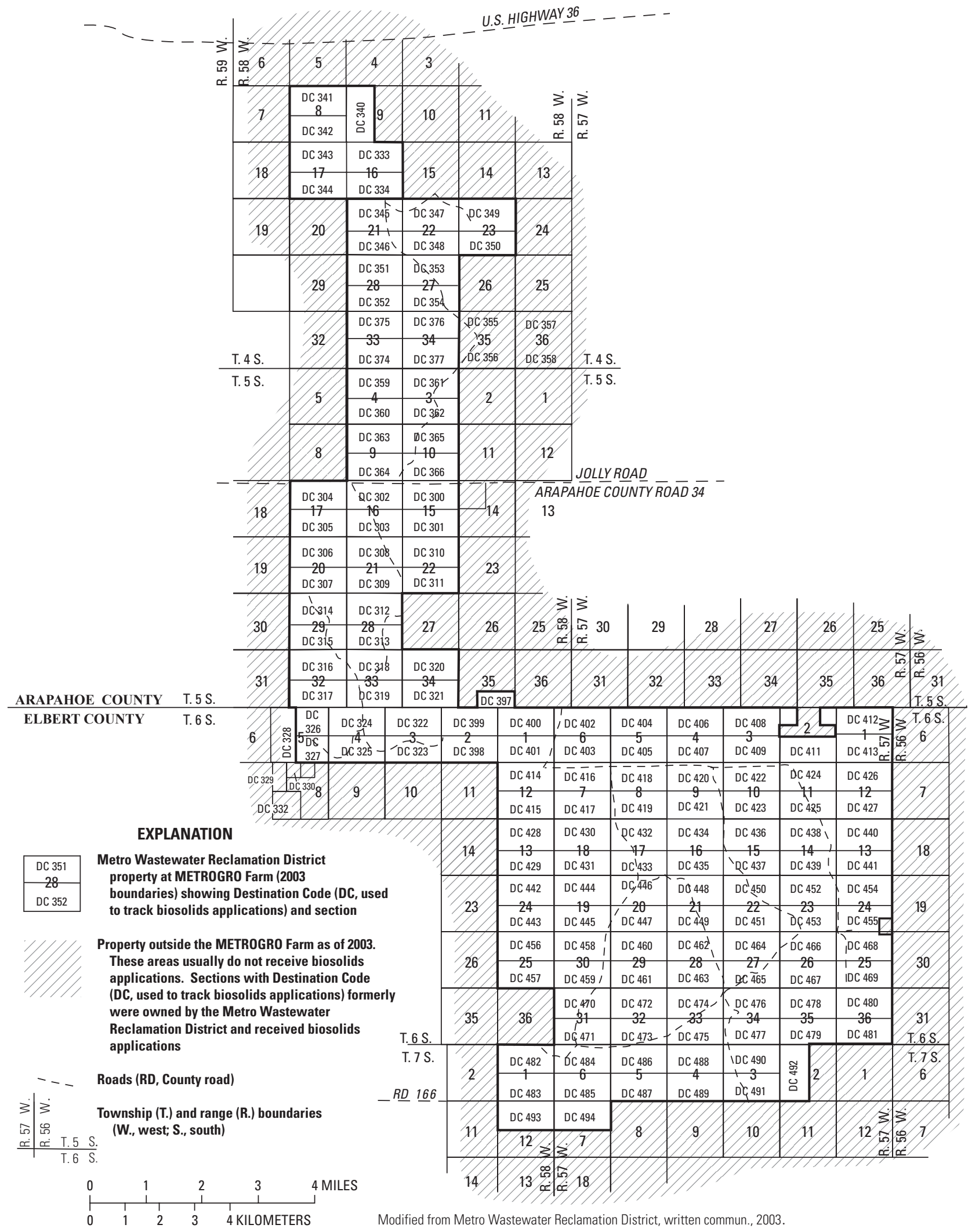


Appendix 2. Comparison of organic wastewater compound data for biosolids and replicate samples collected from the Metro Wastewater Reclamation District and analyzed by the U.S. Geological Survey National Water Quality Laboratory, December 2006.

[Concentrations were not normalized to carbon content; $\mu \mathrm{g} / \mathrm{kg}$, micrograms per kilogram dry weight; RPD, relative percent difference, which is defined for sample-replicate pairs as [(sample value - replicate value $) /($ sample value + replicate value $) / 2)] \times 100$; E, value estimated by laboratory; <, less than; ND, not determined because data were less than the minimum reporting level; $n$, value less than the minimum reporting level]

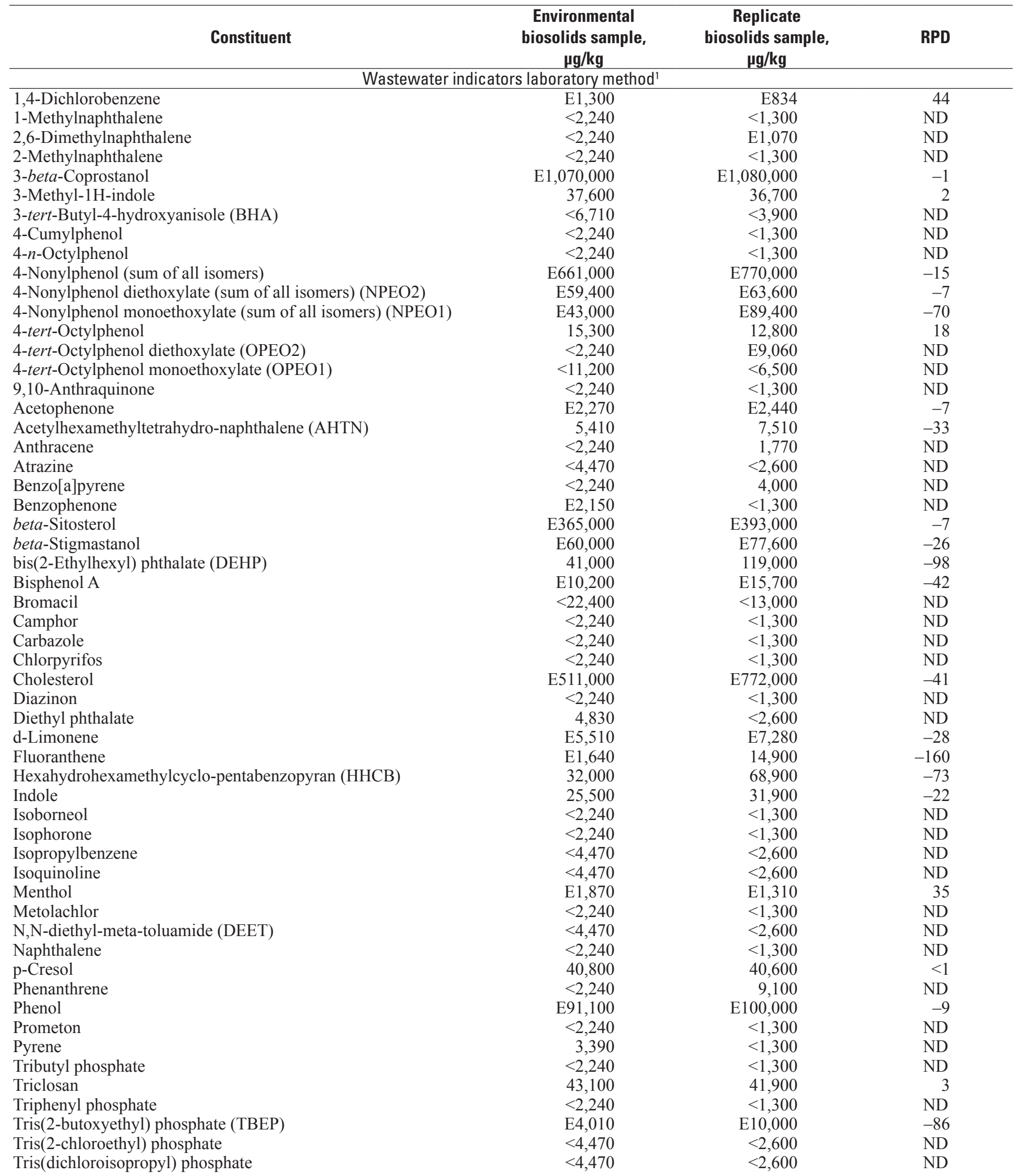


Appendix 2. Comparison of organic wastewater compound data for biosolids and replicate samples collected from the Metro Wastewater Reclamation District and analyzed by the U.S. Geological Survey National Water Quality Laboratory, December 2006.—Continued

[Concentrations were not normalized to carbon content; $\mu \mathrm{g} / \mathrm{kg}$, micrograms per kilogram dry weight; RPD, relative percent difference, which is defined for sample-replicate pairs as [(sample value - replicate value $) /(($ sample value + replicate value $) / 2)] \times 100 ; \mathrm{E}$, value estimated by laboratory; <, less than; ND, not determined because data were less than the minimum reporting level; $n$, value less than the minimum reporting level]

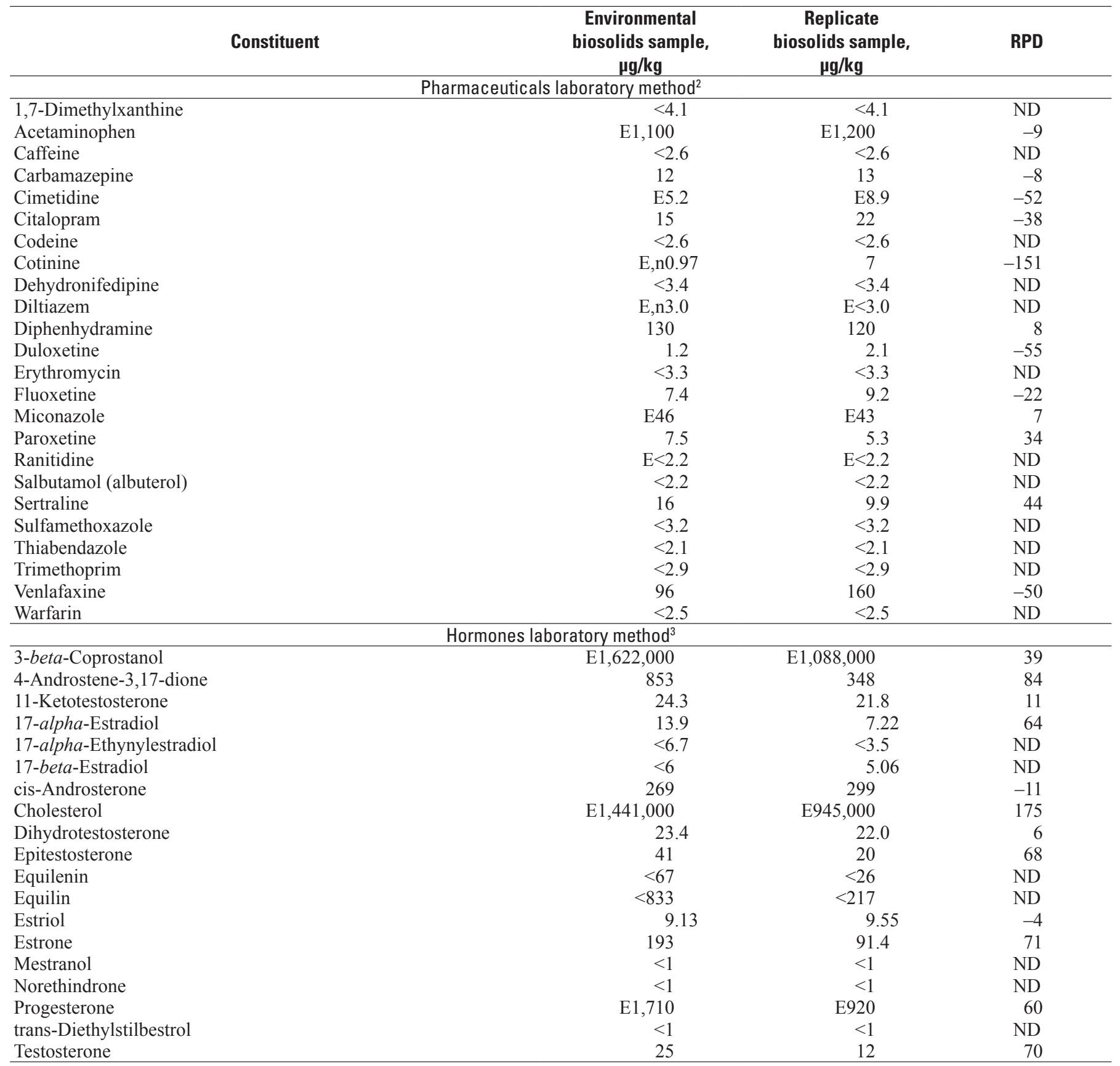

${ }^{1}$ Wastewater-indicator-method analytes were analyzed by the U.S. Geological Survey National Water Quality Laboratory by pressurized solvent extraction, solid-phase extraction, and gas chromatography/mass spectrometry (Burkhardt and others, 2006).

${ }^{2}$ Pharmaceutical-method analytes were analyzed by the U.S. Geological Survey National Water Quality Laboratory through a research method that involved pressurized solvent extraction followed by high-performance liquid chromotography coupled with electrospray ionization/quadrupole mass spectrometry as described by Kinney and others (2006).

${ }^{3}$ Hormone-method analytes were analyzed by the U.S. Geological Survey National Water Quality Laboratory through a research method that involved pressurized solvent extraction, analyte isolation/cleanup, and gas chromotography with tandem mass spectrometry as described by Lee and others (2011). 
Appendix 3. Surrogate and matrix-spike recoveries for fresh biosolids samples collected from the Metro Wastewater Reclamation District and analyzed for organic wastewater compounds by the U.S. Geological Survey National Water Quality Laboratory, 2006.

[Surrogate compounds were added to each sample at the laboratory to evaluate the analytical method for detection, bias, and variability for that particular sample matrix; a surrogate recovery of 100 percent is optimal, but surrogate recoveries of 60 to 130 percent are acceptable for this study. Matrix-spike recoveries are calculated from analysis of a replicate environmental sample that was spiked with a known concentration of target analytes to evaluate bias in the analytical method for that sample matrix. Where concentrations in the unspiked sample were censored at less than the reporting level by the laboratory, the unspiked concentration was assumed to be zero for this analysis; recovery for that analyte could be less than shown. Increased bias is indicated for values where concentrations in the unspiked sample relative to the fortified amount were 100 to 150 percent (italicized values), 150 to 300 percent (bold values), or greater than 300 percent (NR). --, not analyzed; NR, not reported because unspiked concentrations exceeded 300 percent of fortified amount, which produced substantially skewed recoveries; $<$, less than; E, value estimated by laboratory]

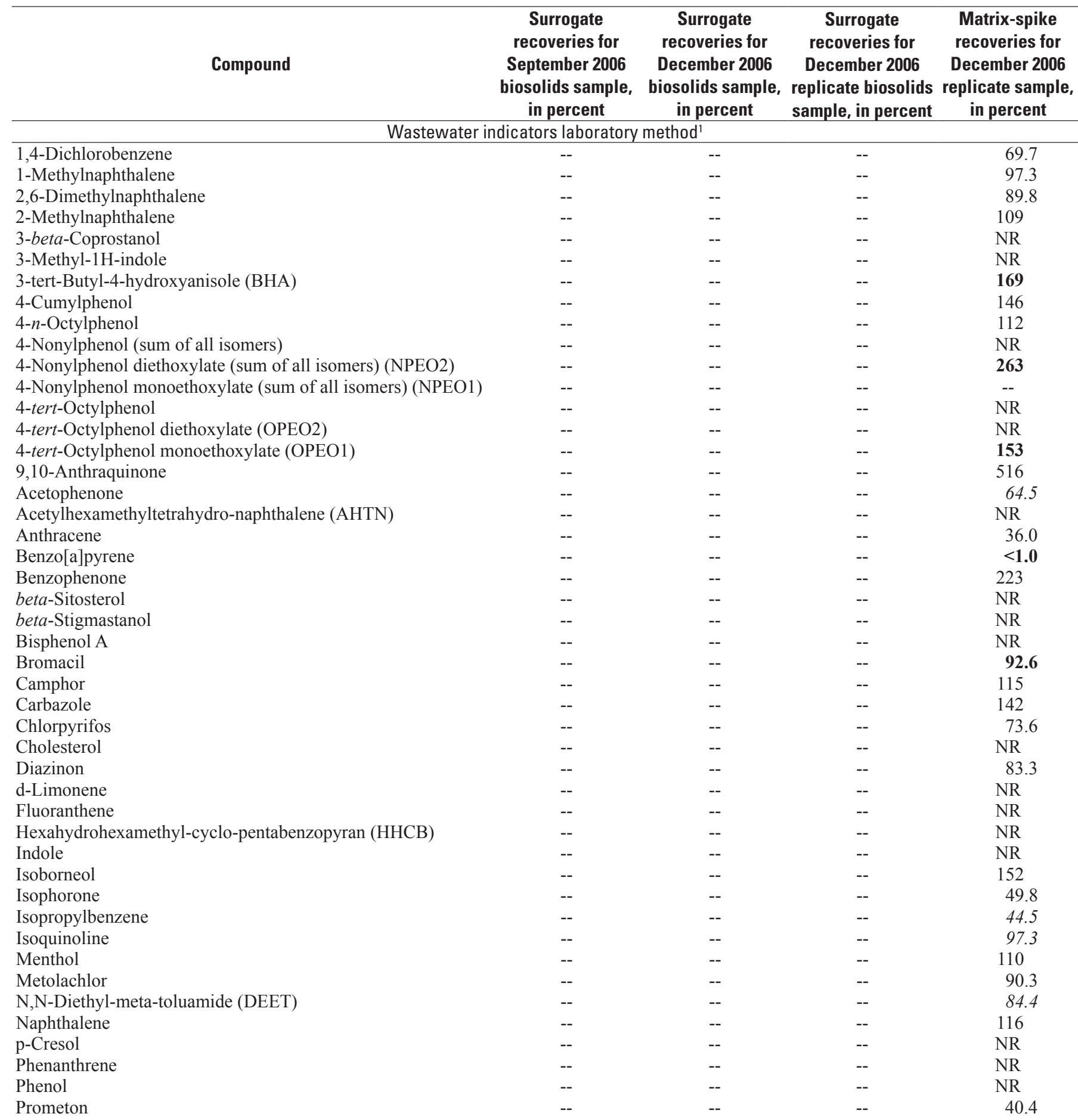


Appendix 3. Surrogate and matrix-spike recoveries for fresh biosolids samples collected from the Metro Wastewater Reclamation District and analyzed for organic wastewater compounds by the U.S. Geological Survey National Water Quality Laboratory, 2006. - Continued

[Surrogate compounds were added to each sample at the laboratory to evaluate the analytical method for detection, bias, and variability for that particular sample matrix; a surrogate recovery of 100 percent is optimal, but surrogate recoveries of 60 to 130 percent are acceptable for this study. Matrix-spike recoveries are calculated from analysis of a replicate environmental sample that was spiked with a known concentration of target analytes to evaluate bias in the analytical method for that sample matrix. Where concentrations in the unspiked sample were censored at less than the reporting level by the laboratory, the unspiked concentration was assumed to be zero for this analysis; recovery for that analyte could be less than shown. Increased bias is indicated for values where concentrations in the unspiked sample relative to the fortified amount were 100 to 150 percent (italicized values), 150 to 300 percent (bold values), or greater than 300 percent (NR). --, not analyzed; NR, not reported because unspiked concentrations exceeded 300 percent of fortified amount, which produced substantially skewed recoveries; $<$, less than; E, value estimated by laboratory]

\begin{tabular}{|c|c|c|c|c|}
\hline Compound & $\begin{array}{c}\text { Surrogate } \\
\text { recoveries for } \\
\text { September } 2006 \\
\text { biosolids sample, } \\
\text { in percent }\end{array}$ & $\begin{array}{c}\text { Surrogate } \\
\text { recoveries for } \\
\text { December } 2006 \\
\text { biosolids sample, } \\
\text { in percent }\end{array}$ & $\begin{array}{c}\text { Surrogate } \\
\text { recoveries for } \\
\text { December } 2006 \\
\text { replicate biosolids } \\
\text { sample, in percent }\end{array}$ & $\begin{array}{c}\text { Matrix-spike } \\
\text { recoveries for } \\
\text { December } 2006 \\
\text { replicate sample, } \\
\text { in percent }\end{array}$ \\
\hline \multicolumn{5}{|c|}{ Wastewater indicators laboratory method'_-Continued } \\
\hline Pyrene & -- & -- & -- & 438 \\
\hline Tributyl phosphate & -- & -- & -- & 152 \\
\hline Tris(2-butoxyethyl) phosphate (TBEP) & -- & -- & -- & NR \\
\hline Tris(2-chloroethyl) phosphate & -- & -- & -- & 67.2 \\
\hline Tris(dichloroisopropyl) phosphate & -- & -- & -- & 156 \\
\hline Decafluorobiphenyl & 31.8 & 13.0 & 22.8 & ${ }^{2} 17$ \\
\hline Fluoranthene-d 10 & 91.2 & 72.0 & 116 & ${ }^{2} 81.6$ \\
\hline \multicolumn{5}{|c|}{ Pharmaceuticals laboratory method ${ }^{3}$} \\
\hline Cotinine & -- & -- & -- & NR \\
\hline Diphenhydramine & -- & -- & -- & NR \\
\hline Duloxetine & -- & -- & -- & 1.2 \\
\hline Fluoxetine & -- & -- & -- & NR \\
\hline Miconazole & -- & -- & -- & NR \\
\hline Paroxetine & -- & -- & -- & NR \\
\hline Sertraline & -- & -- & -- & NR \\
\hline Venlafaxine & -- & -- & -- & NR \\
\hline Carbamazepine-d 10 & -- & 10.2 & 16.3 & 25.4 \\
\hline Ethyl Nicotinate-d4 & -- & 20.7 & 25.5 & ${ }^{2} 27.2$ \\
\hline Fluoxetine-d5 & -- & 3.05 & 2.35 & ${ }^{2} 2.6$ \\
\hline Norfluoxetine-d5 & -- & 10.0 & 10.0 & ${ }^{2} 9.2$ \\
\hline cis-Androsterone & -- & -- & -- & 86.5 \\
\hline Dihydrotestosterone & -- & -- & -- & 76.4 \\
\hline Epitestosterone & -- & -- & -- & 95.2 \\
\hline Equilenin & -- & -- & -- & 154 \\
\hline Estriol & -- & -- & -- & 97.8 \\
\hline Estrone & -- & -- & -- & 129 \\
\hline Mestranol & -- & -- & -- & 109 \\
\hline Norethindrone & -- & -- & -- & 129 \\
\hline Progesterone & -- & -- & -- & 238 \\
\hline Testosterone & -- & -- & -- & 91.8 \\
\hline trans-Diethylstilbestrol & -- & -- & -- & 75.7 \\
\hline 17-beta-Estradiol-d4 & 92.3 & 80.7 & 80.5 & ${ }^{5} 83.8$ \\
\hline
\end{tabular}


Appendix 3. Surrogate and matrix-spike recoveries for fresh biosolids samples collected from the Metro Wastewater Reclamation District and analyzed for organic wastewater compounds by the U.S. Geological Survey National Water Quality Laboratory, 2006. - Continued

[Surrogate compounds were added to each sample at the laboratory to evaluate the analytical method for detection, bias, and variability for that particular sample matrix; a surrogate recovery of 100 percent is optimal, but surrogate recoveries of 60 to 130 percent are acceptable for this study. Matrix-spike recoveries are calculated from analysis of a replicate environmental sample that was spiked with a known concentration of target analytes to evaluate bias in the analytical method for that sample matrix. Where concentrations in the unspiked sample were censored at less than the reporting level by the laboratory, the unspiked concentration was assumed to be zero for this analysis; recovery for that analyte could be less than shown. Increased bias is indicated for values where concentrations in the unspiked sample relative to the fortified amount were 100 to 150 percent (italicized values), 150 to 300 percent (bold values), or greater than 300 percent (NR). --, not analyzed; NR, not reported because unspiked concentrations exceeded 300 percent of fortified amount, which produced substantially skewed recoveries; $<$, less than; E, value estimated by laboratory]

\begin{tabular}{|c|c|c|c|c|}
\hline Compound & $\begin{array}{c}\text { Surrogate } \\
\text { recoveries for } \\
\text { September } 2006 \\
\text { biosolids sample, } \\
\text { in percent }\end{array}$ & $\begin{array}{c}\text { Surrogate } \\
\text { recoveries for } \\
\text { December } 2006 \\
\text { biosolids sample, } \\
\text { in percent }\end{array}$ & $\begin{array}{c}\text { Surrogate } \\
\text { recoveries for } \\
\text { December } 2006 \\
\text { replicate biosolids } \\
\text { sample, in percent }\end{array}$ & $\begin{array}{c}\text { Matrix-spike } \\
\text { recoveries for } \\
\text { December } 2006 \\
\text { replicate sample, } \\
\text { in percent }\end{array}$ \\
\hline \multicolumn{5}{|c|}{ Hormones laboratory method ${ }^{4}$-Continued } \\
\hline Androstenedione-d7 & 113 & 103 & 107 & 599.9 \\
\hline Cholesterol-d7 & 6.8 & 9.8 & 7.5 & ${ }^{5} 5.6$ \\
\hline Estriol-d3 & 60.1 & 68.9 & 45.1 & ${ }^{5} 64.1$ \\
\hline Estrone-d4 & 90.1 & 78.6 & 80.6 & ${ }^{5} 83.2$ \\
\hline Ethynylestradiol-d4 & 116 & 110 & 101 & ${ }^{5} 114$ \\
\hline Mestranol-d4 & 85.5 & 101 & 92.8 & ${ }^{5} 92.4$ \\
\hline Norethindrone-d6 & 68.8 & 55.5 & 63.8 & ${ }^{5} 65.7$ \\
\hline Progesterone-d9 & E243 & E288 & E227 & ${ }^{5} \mathrm{E} 216$ \\
\hline
\end{tabular}

${ }^{1}$ Wastewater-indicator-method analytes were analyzed by the U.S. Geological Survey National Water Quality Laboratory by pressurized solvent extraction, solid-phase extraction, and gas chromatography/mass spectrometry (Burkhardt and others, 2006).

${ }^{2}$ Surrogate data for the spiked sample.

${ }^{3}$ Pharmaceutical-method analytes were analyzed by the U.S. Geological Survey National Water Quality Laboratory through a research method that involved pressurized solvent extraction followed by high-performance liquid chromotography coupled with electrospray ionization/quadrupole mass spectrometry as described by Kinney and others (2006).

${ }^{4}$ Instead of surrogates, the hormone method had isotope dilution standards, which could be used to adjust quantitation. Hormone-method analytes were analyzed by the U.S. Geological Survey National Water Quality Laboratory through a research method that involved pressurized solvent extraction, analyte isolation/cleanup, and gas chromotography with tandem mass spectrometry as described by Lee and others (2011).

${ }^{5}$ Isotope-dilution-standard data for the spiked sample. 
Appendix 4. Analytical data for leachate and groundwater samples associated with the biosolids-application area near Deer Trail, Colorado, 2005.

[All leachate and groundwater chemical-concentration data are from filtered samples; associated data for matrix-spike recoveries are listed in appendix 5; sampling locations near Deer Trail are shown in figure 2; information for groundwater-sampling sites is provided in appendix 6; shaded analytes constitute a preliminary biosolids signature (summarized in table 3); MWRD properties are located near Deer Trail, Colorado, and are shown in figure 2; g, grams; L, liters; $\mu \mathrm{g} / \mathrm{L}$, micrograms per liter; $\%$, percent; $\mu \mathrm{S} / \mathrm{cm}$, microsiemens per centimeter at 25 degrees Celsius; $\mathrm{mg} / \mathrm{L}$, milligrams per liter; fresh, material obtained directly from wastewater treatment plant and processed inside laboratory; dried, material dewatered inside laboratory under forced-air conditions then ground to less than 150 micrometers prior to chemical analysis; MWRD, Metro Wastewater Reclamation District; WWTP, wastewater treatment plant in Denver, Colorado; $\mathrm{ft}$, feet below land surface; <, less than; NA, not analyzed; E, estimated by laboratory; n, less than the minimum reporting level; field aged, material obtained from surface of farm field near Deer Trail, Colorado, about 8 months after application; fresh field, material obtained from surface of farm field near Deer Trail, Colorado, less than one day after deposited; OBW, organic-free blank water (certified); USGS, U.S. Geological Survey]

\begin{tabular}{|c|c|c|c|c|c|c|c|}
\hline $\begin{array}{l}\text { Sample } \\
\text { type }\end{array}$ & $\begin{array}{c}\text { Source } \\
\text { material }\end{array}$ & $\begin{array}{c}\text { Source- } \\
\text { material or } \\
\text { sample-depth } \\
\text { description }\end{array}$ & $\begin{array}{l}\text { Sample } \\
\text { collection } \\
\text { date }\end{array}$ & $\begin{array}{c}\text { Site } \\
\text { description }\end{array}$ & Analysis & $\begin{array}{c}\text { Mass } \\
\text { of solids } \\
\text { leached, } \\
\text { g }\end{array}$ & $\begin{array}{c}\text { Volume of } \\
\text { ultra-clean } \\
\text { water added, } \\
\text { L } \\
\end{array}$ \\
\hline Leachate & Biosolids & $\begin{array}{l}\text { Archive of fresh, } \\
\text { dried (composite) }\end{array}$ & $\begin{array}{l}\text { 8/30/2005 leach of } \\
\text { 9/22/2004 biosolids }\end{array}$ & MWRD WWTP & $\begin{array}{l}\text { Cations }^{1} \text {, wastewater } \\
\text { indicators }\end{array}$ & 50.00 & 1.000 \\
\hline Replicate leachate & Biosolids & $\begin{array}{l}\text { Archive of fresh, } \\
\text { dried (composite) }\end{array}$ & $\begin{array}{l}\text { 8/30/2005 leach of } \\
\text { 9/22/2004 biosolids }\end{array}$ & MWRD WWTP & Wastewater indicators ${ }^{2}$ & 50.00 & 1.000 \\
\hline Leachate & Biosolids & Field aged & $\begin{array}{l}\text { 8/30/2005 leached of } \\
5 / 31 / 2005 \text { field sample }\end{array}$ & $\begin{array}{l}\text { DC300; biosolids applied } \\
\text { between late September } \\
\text { and early October } 2004\end{array}$ & $\begin{array}{l}\text { Cations }{ }^{1} \text {, wastewater } \\
\text { indicators }{ }^{2}\end{array}$ & 50.00 & 1.000 \\
\hline Leachate & Biosolids & $\begin{array}{l}\text { Fresh, dried } \\
\text { (composite) }\end{array}$ & $\begin{array}{l}\text { 8/30/2005 leach of } \\
\text { January } 2005 \text { biosolids }\end{array}$ & MWRD WWTP & $\begin{array}{l}\text { Cations }^{1} \text {, wastewater } \\
\text { indicators }{ }^{2}\end{array}$ & 50.00 & 1.000 \\
\hline Replicate leachate & Biosolids & $\begin{array}{l}\text { Fresh, dried } \\
\text { (composite) }\end{array}$ & $\begin{array}{l}\text { 8/30/2005 leach of } \\
\text { January } 2005 \text { biosolids }\end{array}$ & MWRD WWTP & Wastewater indicators ${ }^{2}$ & 49.96 & 1.000 \\
\hline Leachate & Biosolids & $\begin{array}{l}\text { Fresh, moist } \\
\text { (composite) }\end{array}$ & $\begin{array}{l}\text { 8/30/2005 leach of } \\
8 / 23 / 2005 \text { biosolids }\end{array}$ & MWRD WWTP & Wastewater indicators ${ }^{2}$ & 209.78 & 0.840 \\
\hline Replicate leachate & Biosolids & $\begin{array}{l}\text { Fresh, dried } \\
\text { (composite) }\end{array}$ & $\begin{array}{c}\text { 12/19/2005 leach of } \\
\text { November } 2005 \text { biosolids }\end{array}$ & MWRD WWTP & Pharmaceuticals ${ }^{4}$ & 49.95 & 1.000 \\
\hline Leachate & Cow manure & Fresh field, dried & $\begin{array}{l}\text { 8/30/2005 leach of } \\
5 / 31 / 2005 \text { field sample }\end{array}$ & $\begin{array}{c}\text { South-2 (Cattle, } \\
\text { no farming, no biosolids) }\end{array}$ & Wastewater indicators ${ }^{2}$ & 50.00 & 1.000 \\
\hline Groundwater & Alluvial aquifer & DTX1 at $20 \mathrm{ft}$ & $7 / 5 / 2005$ & MWRD North Property & $\begin{array}{c}\text { Anions }^{3} \text {, cations }{ }^{1}, \\
\text { wastewater indicators }\end{array}$ & 0 & 0 \\
\hline Groundwater & Alluvial aquifer & DTX2 at $14 \mathrm{ft}$ & $7 / 5 / 2005$ & MWRD North Property & $\begin{array}{l}\text { Anions }^{3} \text {, cations }{ }^{1}, \\
\text { wastewater indicators }\end{array}$ & 0 & 0 \\
\hline Groundwater & Alluvial aquifer & D6 at $19 \mathrm{ft}$ & $7 / 6 / 2005$ & MWRD Central Property & $\begin{array}{l}\text { Anions }^{3} \text {, cations }{ }^{1}, \\
\text { wastewater indicators }\end{array}$ & 0 & 0 \\
\hline Replicate groundwa & ater sample & D6 at $19 \mathrm{ft}$ & $7 / 6 / 2005$ & MWRD Central Property & $\begin{array}{l}\text { Anions }^{3} \text {, cations }{ }^{1}, \\
\text { wastewater indicators }\end{array}$ & 0 & 0 \\
\hline Groundwater & Alluvial aquifer & D17 at $16 \mathrm{ft}$ & $7 / 6 / 2005$ & MWRD Central Property & $\begin{array}{l}\text { Anions }^{3} \text {, cations }{ }^{1}, \\
\text { wastewater indicators }{ }^{1}\end{array}$ & 0 & 0 \\
\hline
\end{tabular}

${ }^{1}$ Cations in leachate samples were analyzed by inductively coupled plasma, mass spectrometry except for mercury, which was analyzed by cold vapor atomic absorption spectrometry. Cations in groundwater samples were analyzed according to methods described by Fishman (1993) and summarized by Yager and others (2009).

${ }^{2}$ Wastewater-indicator-method analytes were analyzed by capillary-column gas chromatography/mass spectrometry for leachate samples (continuous liquidliquid extraction; Zaugg and others, 2006) and groundwater samples (polystyrene-divinylbenzene solid-phase extraction; Zaugg and others, 2002).

${ }^{3}$ Anions in leachate and groundwater samples were analyzed by ion chromatography according to methods described by Fishman and Friedman (1989).

${ }^{4}$ Pharmaceutical-method analytes in leachate and groundwater samples were analyzed by solid phase, hydrophilic-lipophilic-balance extraction and highperformance liquid chromatography described by Cahill and others (2004) and further validated in Furlong and others (2008). 
Appendix 4. Analytical data for leachate and groundwater samples associated with the biosolids-application area near Deer Trail, Colorado, 2005.-Continued

[All leachate and groundwater chemical-concentration data are from filtered samples; associated data for matrix-spike recoveries are listed in appendix 5; sampling locations near Deer Trail are shown in figure 2; information for groundwater-sampling sites is provided in appendix 6; shaded analytes constitute a preliminary biosolids signature (summarized in table 3); MWRD properties are located near Deer Trail, Colorado, and are shown in figure 2; g, grams; L, liters; $\mu \mathrm{g} / \mathrm{L}$, micrograms per liter; $\%$, percent; $\mu \mathrm{S} / \mathrm{cm}$, microsiemens per centimeter at 25 degrees Celsius; $\mathrm{mg} / \mathrm{L}$, milligrams per liter; fresh, material obtained directly from wastewater treatment plant and processed inside laboratory; dried, material dewatered inside laboratory under forced-air conditions then ground to less than 150 micrometers prior to chemical analysis; MWRD, Metro Wastewater Reclamation District; WWTP, wastewater treatment plant in Denver, Colorado; $\mathrm{ft}$, feet below land surface; <, less than; NA, not analyzed; E, estimated by laboratory; $\mathrm{n}$, less than the minimum reporting level; field aged, material obtained from surface of farm field near Deer Trail, Colorado, about 8 months after application; fresh field, material obtained from surface of farm field near Deer Trail, Colorado, less than one day after deposited; OBW, organic-free blank water (certified); USGS, U.S. Geological Survey]

\begin{tabular}{|c|c|c|c|c|c|c|c|}
\hline $\begin{array}{c}\text { Filtration date } \\
\text { for analyses of } \\
\text { organic chemicals }\end{array}$ & $\begin{array}{l}\text { Filtration date } \\
\text { for analyses of } \\
\text { inorganic } \\
\text { chemicals }\end{array}$ & $\begin{array}{l}\text { pH (laboratory if } \\
\text { leachate or blank; } \\
\text { field if groundwater), } \\
\text { standard units }\end{array}$ & $\begin{array}{c}\text { Specific conductance } \\
\text { (laboratory if leachate or blank; } \\
\text { field if groundwater), } \\
\mu \mathrm{S} / \mathrm{cm}\end{array}$ & $\begin{array}{l}\text { Calcium, } \\
\text { dissolved, } \\
\text { mg/L }\end{array}$ & $\begin{array}{l}\text { Chloride, } \\
\text { dissolved, } \\
\text { mg/L }\end{array}$ & $\begin{array}{c}\text { Fluoride, } \\
\text { dissolved, } \\
\text { mg/L }\end{array}$ & $\begin{array}{l}\text { Magnesium, } \\
\text { dissolved, } \\
\text { mg/L }\end{array}$ \\
\hline $9 / 1 / 2005$ & $8 / 30 / 2005$ & NA & NA & 5.33 & NA & NA & 2.07 \\
\hline $9 / 1 / 2005$ & NA & NA & NA & NA & NA & NA & NA \\
\hline $9 / 1 / 2005$ & $8 / 30 / 2005$ & NA & NA & 8.62 & NA & NA & 1.86 \\
\hline $9 / 1 / 2005$ & $8 / 30 / 2005$ & NA & NA & 9.1 & NA & NA & 3.24 \\
\hline $9 / 1 / 2005$ & NA & NA & NA & NA & NA & NA & NA \\
\hline $9 / 2 / 2005$ & NA & NA & NA & NA & NA & NA & NA \\
\hline $12 / 20 / 2005$ & NA & NA & NA & NA & NA & NA & NA \\
\hline $9 / 1 / 2005$ & NA & NA & NA & NA & NA & NA & NA \\
\hline $7 / 9 / 2005$ & $7 / 5 / 2005$ & 7.1 & 4,110 & 494 & 51.7 & 0.79 & 233 \\
\hline $7 / 9 / 2005$ & $7 / 5 / 2005$ & 6.8 & 4,710 & 489 & 68.1 & 0.61 & 232 \\
\hline $7 / 10 / 2005$ & $7 / 6 / 2005$ & 7.2 & 16,300 & 436 & 394 & 1.25 & 2,700 \\
\hline $7 / 10 / 2005$ & $7 / 6 / 2005$ & 7.2 & 16,400 & 428 & 389 & 1.26 & 2,660 \\
\hline $7 / 10 / 2005$ & $7 / 6 / 2005$ & 7.6 & 490 & 58.8 & 2.26 & 1.4 & 20 \\
\hline
\end{tabular}


Appendix 4. Analytical data for leachate and groundwater samples associated with the biosolids-application area near Deer Trail, Colorado, 2005.-Continued

[All leachate and groundwater chemical-concentration data are from filtered samples; associated data for matrix-spike recoveries are listed in appendix 5; sampling locations near Deer Trail are shown in figure 2; information for groundwater-sampling sites is provided in appendix 6; shaded analytes constitute a preliminary biosolids signature (summarized in table 3); MWRD properties are located near Deer Trail, Colorado, and are shown in figure 2; g, grams; L, liters; $\mu \mathrm{g} / \mathrm{L}$, micrograms per liter; $\%$, percent; $\mu \mathrm{S} / \mathrm{cm}$, microsiemens per centimeter at 25 degrees Celsius; $\mathrm{mg} / \mathrm{L}$, milligrams per liter; fresh, material obtained directly from wastewater treatment plant and processed inside laboratory; dried, material dewatered inside laboratory under forced-air conditions then ground to less than 150 micrometers prior to chemical analysis; MWRD, Metro Wastewater Reclamation District; WWTP, wastewater treatment plant in Denver, Colorado; $\mathrm{ft}$, feet below land surface; <, less than; NA, not analyzed; E, estimated by laboratory; n, less than the minimum reporting level; field aged, material obtained from surface of farm field near Deer Trail, Colorado, about 8 months after application; fresh field, material obtained from surface of farm field near Deer Trail, Colorado, less than one day after deposited; OBW, organic-free blank water (certified); USGS, U.S. Geological Survey]

\begin{tabular}{|c|c|c|c|c|c|c|c|}
\hline $\begin{array}{l}\text { Sample } \\
\text { type }\end{array}$ & $\begin{array}{l}\text { Source } \\
\text { material }\end{array}$ & $\begin{array}{c}\text { Source- } \\
\text { material or } \\
\text { sample-depth } \\
\text { description }\end{array}$ & $\begin{array}{l}\text { Sample } \\
\text { collection } \\
\text { date }\end{array}$ & $\begin{array}{c}\text { Site } \\
\text { description }\end{array}$ & $\begin{array}{l}\text { Potassium, } \\
\text { dissolved, } \\
\text { mg/L }\end{array}$ & $\begin{array}{c}\text { Silica, } \\
\text { dissolved, } \\
\text { mg/L }\end{array}$ & $\begin{array}{c}\text { Sodium, } \\
\text { dissolved, } \\
\text { mg/L }\end{array}$ \\
\hline Leachate & Biosolids & $\begin{array}{l}\text { Archive of fresh, } \\
\text { dried (composite) }\end{array}$ & $\begin{array}{l}\text { 8/30/2005 leach of } \\
9 / 22 / 2004 \text { biosolids }\end{array}$ & MWRD WWTP & 18.4 & 8.6 & 15.1 \\
\hline Replicate leachate & Biosolids & $\begin{array}{l}\text { Archive of fresh, } \\
\text { dried (composite) }\end{array}$ & $\begin{array}{l}\text { 8/30/2005 leach of } \\
\text { 9/22/2004 biosolids }\end{array}$ & MWRD WWTP & NA & NA & NA \\
\hline Leachate & Biosolids & Field aged & $\begin{array}{l}\text { 8/30/2005 leached of } \\
5 / 31 / 2005 \text { field sample }\end{array}$ & $\begin{array}{l}\text { DC300; biosolids applied } \\
\text { between late September } \\
\text { and early October } 2004\end{array}$ & 9.30 & 4.2 & 6.54 \\
\hline Leachate & Biosolids & $\begin{array}{l}\text { Fresh, dried } \\
\text { (composite) }\end{array}$ & $\begin{array}{l}\text { 8/30/2005 leach of } \\
\text { January } 2005 \text { biosolids }\end{array}$ & MWRD WWTP & 18.6 & 6.9 & 23.8 \\
\hline Replicate leachate & Biosolids & $\begin{array}{l}\text { Fresh, dried } \\
\text { (composite) }\end{array}$ & $\begin{array}{l}\text { 8/30/2005 leach of } \\
\text { January } 2005 \text { biosolids }\end{array}$ & MWRD WWTP & NA & NA & NA \\
\hline Leachate & Biosolids & $\begin{array}{l}\text { Fresh, moist } \\
\text { (composite) }\end{array}$ & $\begin{array}{l}\text { 8/30/2005 leach of } \\
8 / 23 / 2005 \text { biosolids }\end{array}$ & MWRD WWTP & NA & NA & NA \\
\hline Replicate leachate & Biosolids & $\begin{array}{l}\text { Fresh, dried } \\
\text { (composite) }\end{array}$ & $\begin{array}{c}12 / 19 / 2005 \text { leach of } \\
\text { November } 2005 \text { biosolids }\end{array}$ & MWRD WWTP & NA & NA & NA \\
\hline Leachate & Cow manure & Fresh field, dried & $\begin{array}{l}\text { 8/30/2005 leach of } \\
5 / 31 / 2005 \text { field sample }\end{array}$ & $\begin{array}{c}\text { South-2 (Cattle, } \\
\text { no farming, no biosolids) }\end{array}$ & NA & NA & NA \\
\hline Groundwater & Alluvial aquifer & DTX1 at $20 \mathrm{ft}$ & $7 / 5 / 2005$ & MWRD North Property & 3.75 & 35.2 & 379 \\
\hline Groundwater & Alluvial aquifer & DTX2 at $14 \mathrm{ft}$ & $7 / 5 / 2005$ & MWRD North Property & 9.00 & 17.5 & 508 \\
\hline Groundwater & Alluvial aquifer & D6 at $19 \mathrm{ft}$ & $7 / 6 / 2005$ & MWRD Central Property & 15.4 & 23.9 & 2,330 \\
\hline \multicolumn{2}{|c|}{ Replicate groundwater sample } & D6 at $19 \mathrm{ft}$ & $7 / 6 / 2005$ & MWRD Central Property & 13.7 & 23.4 & 2,280 \\
\hline Groundwater & Alluvial aquifer & $\mathrm{D} 17$ at $16 \mathrm{ft}$ & $7 / 6 / 2005$ & MWRD Central Property & 1.56 & 19.7 & 16.9 \\
\hline Groundwater & Alluvial aquifer & $\mathrm{D} 25$ at $18 \mathrm{ft}$ & $7 / 5 / 2005$ & MWRD Central Property & 7.74 & 29.7 & 292 \\
\hline \multicolumn{2}{|c|}{ Leachate equipment blank } & OBW & $8 / 30 / 2005$ & USGS laboratory & 0.04 & 1.0 & 2.61 \\
\hline \multicolumn{2}{|c|}{ Leachate equipment blank } & OBW & $12 / 19 / 2005$ & USGS laboratory & NA & NA & NA \\
\hline \multicolumn{2}{|c|}{ Field blank for groundwater samples } & OBW & $7 / 6 / 2005$ & $\begin{array}{c}\text { MWRD } \\
\text { Central Property (D6) }\end{array}$ & $<0.16$ & $<0.36$ & $<0.20$ \\
\hline
\end{tabular}


Appendix 4. Analytical data for leachate and groundwater samples associated with the biosolids-application area near Deer Trail, Colorado, 2005.-Continued

[All leachate and groundwater chemical-concentration data are from filtered samples; associated data for matrix-spike recoveries are listed in appendix 5; sampling locations near Deer Trail are shown in figure 2; information for groundwater-sampling sites is provided in appendix 6; shaded analytes constitute a preliminary biosolids signature (summarized in table 3); MWRD properties are located near Deer Trail, Colorado, and are shown in figure 2; g, grams; L, liters; $\mu \mathrm{g} / \mathrm{L}$, micrograms per liter; $\%$, percent; $\mu \mathrm{S} / \mathrm{cm}$, microsiemens per centimeter at 25 degrees Celsius; $\mathrm{mg} / \mathrm{L}$, milligrams per liter; fresh, material obtained directly from wastewater treatment plant and processed inside laboratory; dried, material dewatered inside laboratory under forced-air conditions then ground to less than 150 micrometers prior to chemical analysis; MWRD, Metro Wastewater Reclamation District; WWTP, wastewater treatment plant in Denver, Colorado; $\mathrm{ft}$, feet below land surface; <, less than; NA, not analyzed; E, estimated by laboratory; n, less than the minimum reporting level; field aged, material obtained from surface of farm field near Deer Trail, Colorado, about 8 months after application; fresh field, material obtained from surface of farm field near Deer Trail, Colorado, less than one day after deposited; OBW, organic-free blank water (certified); USGS, U.S. Geological Survey]

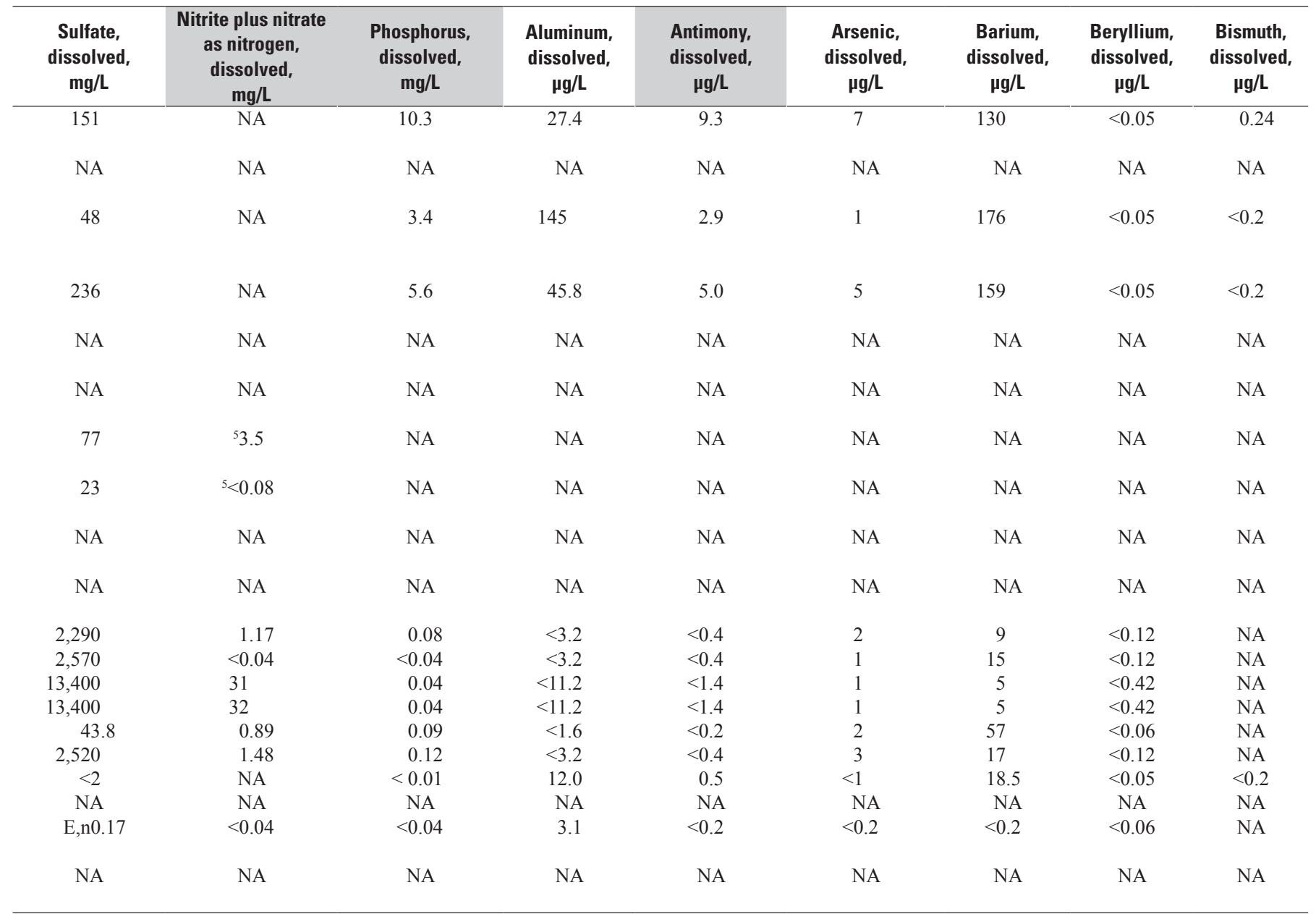

\footnotetext{
${ }^{5}$ Analysis was for nitrate nitrogen by ion chromatography according to the method described by Fishman and Friedman (1989).
} 
Appendix 4. Analytical data for leachate and groundwater samples associated with the biosolids-application area near Deer Trail, Colorado, 2005.-Continued

[All leachate and groundwater chemical-concentration data are from filtered samples; associated data for matrix-spike recoveries are listed in appendix 5; sampling locations near Deer Trail are shown in figure 2; information for groundwater-sampling sites is provided in appendix 6; shaded analytes constitute a preliminary biosolids signature (summarized in table 3); MWRD properties are located near Deer Trail, Colorado, and are shown in figure 2; g, grams; L, liters; $\mu \mathrm{g} / \mathrm{L}$, micrograms per liter; $\%$, percent; $\mu \mathrm{S} / \mathrm{cm}$, microsiemens per centimeter at 25 degrees Celsius; $\mathrm{mg} / \mathrm{L}$, milligrams per liter; fresh, material obtained directly from wastewater treatment plant and processed inside laboratory; dried, material dewatered inside laboratory under forced-air conditions then ground to less than 150 micrometers prior to chemical analysis; MWRD, Metro Wastewater Reclamation District; WWTP, wastewater treatment plant in Denver, Colorado; $\mathrm{ft}$, feet below land surface; <, less than; NA, not analyzed; E, estimated by laboratory; n, less than the minimum reporting level; field aged, material obtained from surface of farm field near Deer Trail, Colorado, about 8 months after application; fresh field, material obtained from surface of farm field near Deer Trail, Colorado, less than one day after deposited; OBW, organic-free blank water (certified); USGS, U.S. Geological Survey]

\begin{tabular}{|c|c|c|c|c|c|c|c|}
\hline $\begin{array}{l}\text { Sample } \\
\text { type }\end{array}$ & $\begin{array}{l}\text { Source } \\
\text { material }\end{array}$ & $\begin{array}{c}\text { Source- } \\
\text { material or } \\
\text { sample-depth } \\
\text { description }\end{array}$ & $\begin{array}{c}\text { Sample } \\
\text { collection } \\
\text { date }\end{array}$ & $\begin{array}{c}\text { Site } \\
\text { description }\end{array}$ & $\begin{array}{c}\text { Cadmium, } \\
\text { dissolved, } \\
\mu \mathrm{g} / \mathrm{L}\end{array}$ & $\begin{array}{c}\text { Cerium, } \\
\text { dissolved, } \\
\mu \mathrm{g} / \mathrm{L}\end{array}$ & $\begin{array}{c}\text { Cesium, } \\
\text { dissolved, } \\
\mu \mathrm{g} / \mathrm{L}\end{array}$ \\
\hline Leachate & Biosolids & $\begin{array}{l}\text { Archive of fresh, } \\
\text { dried (composite) }\end{array}$ & $\begin{array}{l}\text { 8/30/2005 leach of } \\
9 / 22 / 2004 \text { biosolids }\end{array}$ & MWRD WWTP & 0.48 & 0.05 & 0.06 \\
\hline Replicate leachate & Biosolids & $\begin{array}{l}\text { Archive of fresh, } \\
\text { dried (composite) }\end{array}$ & $\begin{array}{l}\text { 8/30/2005 leach of } \\
\text { 9/22/2004 biosolids }\end{array}$ & MWRD WWTP & NA & NA & NA \\
\hline Leachate & Biosolids & Field aged & $\begin{array}{l}\text { 8/30/2005 leached of } \\
5 / 31 / 2005 \text { field sample }\end{array}$ & $\begin{array}{l}\text { DC300; biosolids applied } \\
\text { between late September } \\
\text { and early October } 2004\end{array}$ & 0.19 & 0.49 & $<0.02$ \\
\hline Leachate & Biosolids & $\begin{array}{l}\text { Fresh, dried } \\
\text { (composite) }\end{array}$ & $\begin{array}{l}\text { 8/30/2005 leach of } \\
\text { January } 2005 \text { biosolids }\end{array}$ & MWRD WWTP & 0.46 & 0.06 & 0.07 \\
\hline Replicate leachate & Biosolids & $\begin{array}{l}\text { Fresh, dried } \\
\text { (composite) }\end{array}$ & $\begin{array}{l}\text { 8/30/2005 leach of } \\
\text { January } 2005 \text { biosolids }\end{array}$ & MWRD WWTP & NA & NA & NA \\
\hline Leachate & Biosolids & $\begin{array}{l}\text { Fresh, moist } \\
\text { (composite) }\end{array}$ & $\begin{array}{l}\text { 8/30/2005 leach of } \\
8 / 23 / 2005 \text { biosolids }\end{array}$ & MWRD WWTP & NA & NA & NA \\
\hline Replicate leachate & Biosolids & $\begin{array}{l}\text { Fresh, dried } \\
\text { (composite) }\end{array}$ & $\begin{array}{l}12 / 19 / 2005 \text { leach of } \\
\text { November } 2005 \text { biosolids }\end{array}$ & MWRD WWTP & NA & NA & NA \\
\hline Leachate & Cow manure & Fresh field, dried & $\begin{array}{l}\text { 8/30/2005 leach of } \\
5 / 31 / 2005 \text { field sample }\end{array}$ & $\begin{array}{c}\text { South-2 (Cattle, } \\
\text { no farming, no biosolids) }\end{array}$ & NA & NA & NA \\
\hline Groundwater & Alluvial aquifer & DTX1 at $20 \mathrm{ft}$ & $7 / 5 / 2005$ & MWRD North Property & 0.14 & NA & NA \\
\hline Groundwater & Alluvial aquifer & DTX2 at $14 \mathrm{ft}$ & $7 / 5 / 2005$ & MWRD North Property & 0.08 & NA & NA \\
\hline Groundwater & Alluvial aquifer & D6 at $19 \mathrm{ft}$ & $7 / 6 / 2005$ & MWRD Central Property & $<0.28$ & NA & NA \\
\hline \multicolumn{2}{|c|}{ Replicate groundwater sample } & D6 at $19 \mathrm{ft}$ & $7 / 6 / 2005$ & MWRD Central Property & $<0.28$ & NA & NA \\
\hline Groundwater & Alluvial aquifer & $\mathrm{D} 17$ at $16 \mathrm{ft}$ & $7 / 6 / 2005$ & MWRD Central Property & E,n 0.02 & NA & NA \\
\hline Groundwater & Alluvial aquifer & $\mathrm{D} 25$ at $18 \mathrm{ft}$ & $7 / 5 / 2005$ & MWRD Central Property & 0.21 & NA & NA \\
\hline \multicolumn{2}{|c|}{ Leachate equipment blank } & OBW & $8 / 30 / 2005$ & USGS laboratory & $<0.02$ & $<0.01$ & $<0.02$ \\
\hline \multirow{2}{*}{\multicolumn{2}{|c|}{$\begin{array}{l}\text { Leachate equipment blank } \\
\text { Field blank for groundwater samples }\end{array}$}} & OBW & $12 / 19 / 2005$ & USGS laboratory & NA & NA & NA \\
\hline & & OBW & $7 / 6 / 2005$ & $\begin{array}{c}\text { MWRD } \\
\text { Central Property (D6) }\end{array}$ & $<0.04$ & NA & NA \\
\hline
\end{tabular}


Appendix 4. Analytical data for leachate and groundwater samples associated with the biosolids-application area near Deer Trail, Colorado, 2005.-Continued

[All leachate and groundwater chemical-concentration data are from filtered samples; associated data for matrix-spike recoveries are listed in appendix 5; sampling locations near Deer Trail are shown in figure 2; information for groundwater-sampling sites is provided in appendix 6; shaded analytes constitute a preliminary biosolids signature (summarized in table 3); MWRD properties are located near Deer Trail, Colorado, and are shown in figure 2; g, grams; L, liters; $\mu \mathrm{g} / \mathrm{L}$, micrograms per liter; $\%$, percent; $\mu \mathrm{S} / \mathrm{cm}$, microsiemens per centimeter at 25 degrees Celsius; $\mathrm{mg} / \mathrm{L}$, milligrams per liter; fresh, material obtained directly from wastewater treatment plant and processed inside laboratory; dried, material dewatered inside laboratory under forced-air conditions then ground to less than 150 micrometers prior to chemical analysis; MWRD, Metro Wastewater Reclamation District; WWTP, wastewater treatment plant in Denver, Colorado; $\mathrm{ft}$, feet below land surface; <, less than; NA, not analyzed; E, estimated by laboratory; n, less than the minimum reporting level; field aged, material obtained from surface of farm field near Deer Trail, Colorado, about 8 months after application; fresh field, material obtained from surface of farm field near Deer Trail, Colorado, less than one day after deposited; OBW, organic-free blank water (certified); USGS, U.S. Geological Survey]

\begin{tabular}{|c|c|c|c|c|c|c|c|c|c|c|}
\hline $\begin{array}{c}\text { Chromium, } \\
\text { dissolved, } \\
\mu \mathrm{g} / \mathrm{L}\end{array}$ & $\begin{array}{c}\text { Cobalt, } \\
\text { dissolved, } \\
\mu \mathrm{g} / \mathrm{L}\end{array}$ & $\begin{array}{c}\text { Copper, } \\
\text { dissolved, } \\
\mu \mathrm{g} / \mathrm{L}\end{array}$ & $\begin{array}{c}\text { Dysprosium, } \\
\text { dissolved, } \\
\mu \mathrm{g} / \mathrm{L}\end{array}$ & $\begin{array}{c}\text { Erbium, } \\
\text { dissolved, } \\
\mu \mathrm{g} / \mathrm{L}\end{array}$ & $\begin{array}{c}\text { Europium, } \\
\text { dissolved, } \\
\mu \mathrm{g} / \mathrm{L}\end{array}$ & $\begin{array}{c}\text { Gadolinium, } \\
\text { dissolved, } \\
\mu \mathrm{g} / \mathrm{L}\end{array}$ & $\begin{array}{c}\text { Gallium, } \\
\text { dissolved, } \\
\mu \mathrm{g} / \mathrm{L}\end{array}$ & $\begin{array}{c}\text { Germanium, } \\
\text { dissolved, } \\
\mu \mathrm{g} / \mathrm{L}\end{array}$ & $\begin{array}{c}\text { Holmium, } \\
\text { dissolved, } \\
\mu \mathrm{g} / \mathrm{L}\end{array}$ & $\begin{array}{c}\text { Iron, } \\
\text { dissolved, } \\
\mu \mathrm{g} / \mathrm{L}\end{array}$ \\
\hline 4.2 & 12 & 101 & $<0.005$ & $<0.005$ & 0.03 & 0.01 & 0.3 & 0.1 & $<0.005$ & 139 \\
\hline NA & NA & NA & NA & NA & NA & NA & NA & NA & NA & NA \\
\hline$<1$ & 5.4 & 92.2 & 0.06 & 0.02 & 0.04 & 0.04 & 0.1 & 0.1 & 0.01 & 113 \\
\hline 3.2 & 16.5 & 115 & 0.01 & 0.01 & 0.03 & 0.02 & 0.1 & 0.1 & $<0.005$ & 62 \\
\hline NA & NA & NA & NA & NA & NA & NA & NA & NA & NA & NA \\
\hline NA & NA & NA & NA & NA & NA & NA & NA & NA & NA & NA \\
\hline NA & NA & NA & NA & NA & NA & NA & NA & NA & NA & NA \\
\hline NA & NA & NA & NA & NA & NA & NA & NA & NA & NA & NA \\
\hline 1 & 0.74 & 5.9 & NA & NA & NA & NA & NA & NA & NA & $<18$ \\
\hline 0.05 & 5.4 & 5.6 & NA & NA & NA & NA & NA & NA & NA & 449 \\
\hline$<1.6$ & 7.5 & 45 & NA & NA & NA & NA & NA & NA & NA & $<90$ \\
\hline$<1.6$ & 6.8 & 48 & NA & NA & NA & NA & NA & NA & NA & $<90$ \\
\hline$<0.8$ & 0.16 & E,n 0.3 & NA & NA & NA & NA & NA & NA & NA & $<6$ \\
\hline 0.15 & 3.3 & 6.8 & NA & NA & NA & NA & NA & NA & NA & $<18$ \\
\hline$<1$ & $<0.02$ & 0.92 & $<0.005$ & $<0.005$ & 0.005 & $<0.005$ & $<0.05$ & $<0.05$ & $<0.005$ & $<50$ \\
\hline NA & NA & NA & NA & NA & NA & NA & NA & NA & NA & NA \\
\hline$<0.8$ & $<0.01$ & $<0.4$ & NA & NA & NA & NA & NA & NA & NA & $<6$ \\
\hline
\end{tabular}


Appendix 4. Analytical data for leachate and groundwater samples associated with the biosolids-application area near Deer Trail, Colorado, 2005-Continued

[All leachate and groundwater chemical-concentration data are from filtered samples; associated data for matrix-spike recoveries are listed in appendix 5; sampling locations near Deer Trail are shown in figure 2; information for groundwater-sampling sites is provided in appendix 6; shaded analytes constitute a preliminary biosolids signature (summarized in table 3); MWRD properties are located near Deer Trail, Colorado, and are shown in figure 2; g, grams; L, liters; $\mu \mathrm{g} / \mathrm{L}$, micrograms per liter; $\%$, percent; $\mu \mathrm{S} / \mathrm{cm}$, microsiemens per centimeter at 25 degrees Celsius; $\mathrm{mg} / \mathrm{L}$, milligrams per liter; fresh, material obtained directly from wastewater treatment plant and processed inside laboratory; dried, material dewatered inside laboratory under forced-air conditions then ground to less than 150 micrometers prior to chemical analysis; MWRD, Metro Wastewater Reclamation District; WWTP, wastewater treatment plant in Denver, Colorado; $\mathrm{ft}$, feet below land surface; <, less than; NA, not analyzed; E, estimated by laboratory; $\mathrm{n}$, less than the minimum reporting level; field aged, material obtained from surface of farm field near Deer Trail, Colorado, about 8 months after application; fresh field, material obtained from surface of farm field near Deer Trail, Colorado, less than one day after deposited; OBW, organic-free blank water (certified); USGS, U.S. Geological Survey]

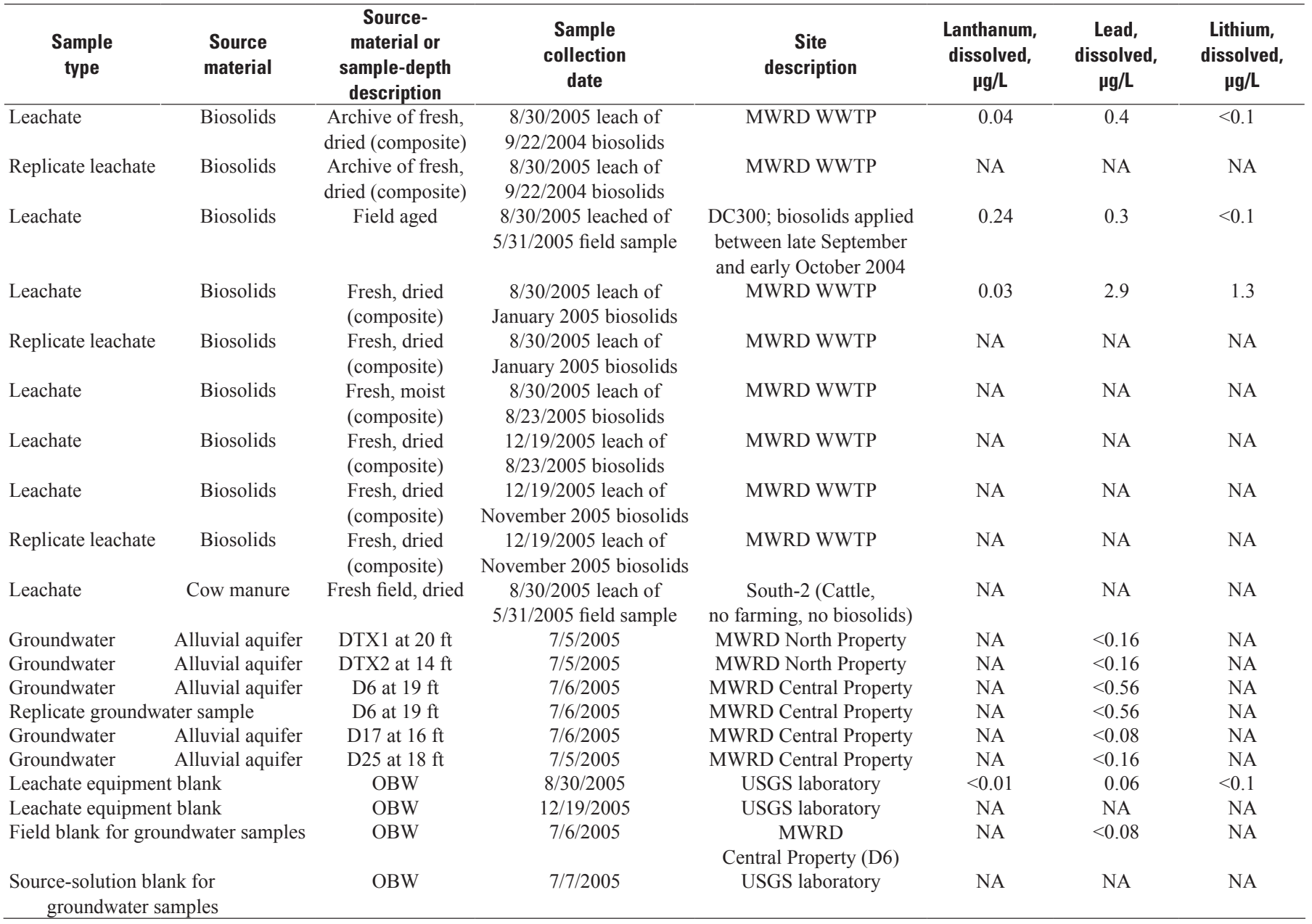


Appendix 4. Analytical data for leachate and groundwater samples associated with the biosolids-application area near Deer Trail, Colorado, 2005-Continued

[All leachate and groundwater chemical-concentration data are from filtered samples; associated data for matrix-spike recoveries are listed in appendix 5; sampling locations near Deer Trail are shown in figure 2; information for groundwater-sampling sites is provided in appendix 6; shaded analytes constitute a preliminary biosolids signature (summarized in table 3); MWRD properties are located near Deer Trail, Colorado, and are shown in figure 2; g, grams; L, liters; $\mu \mathrm{g} / \mathrm{L}$, micrograms per liter; $\%$, percent; $\mu \mathrm{S} / \mathrm{cm}$, microsiemens per centimeter at 25 degrees Celsius; $\mathrm{mg} / \mathrm{L}$, milligrams per liter; fresh, material obtained directly from wastewater treatment plant and processed inside laboratory; dried, material dewatered inside laboratory under forced-air conditions then ground to less than 150 micrometers prior to chemical analysis; MWRD, Metro Wastewater Reclamation District; WWTP, wastewater treatment plant in Denver, Colorado; $\mathrm{ft}$, feet below land surface; <, less than; NA, not analyzed; E, estimated by laboratory; $\mathrm{n}$, less than the minimum reporting level; field aged, material obtained from surface of farm field near Deer Trail, Colorado, about 8 months after application; fresh field, material obtained from surface of farm field near Deer Trail, Colorado, less than one day after deposited; OBW, organic-free blank water (certified); USGS, U.S. Geological Survey]

\begin{tabular}{|c|c|c|c|c|c|c|c|c|c|}
\hline $\begin{array}{l}\text { Lutetium, } \\
\text { dissolved, } \\
\mu \mathrm{g} / \mathrm{L}\end{array}$ & $\begin{array}{c}\text { Manganese, } \\
\text { dissolved, } \\
\mu \mathrm{g} / \mathrm{L}\end{array}$ & $\begin{array}{c}\text { Mercury, } \\
\text { dissolved, } \\
\mu \mathrm{g} / \mathrm{L}\end{array}$ & $\begin{array}{c}\text { Molybdenum, } \\
\text { dissolved, } \\
\mu \mathrm{g} / \mathrm{L}\end{array}$ & $\begin{array}{l}\text { Neodymium, } \\
\text { dissolved, } \\
\mu \mathrm{g} / \mathrm{L}\end{array}$ & $\begin{array}{c}\text { Nickel, } \\
\text { dissolved, } \\
\mu \mathrm{g} / \mathrm{L}\end{array}$ & $\begin{array}{c}\text { Niobium, } \\
\text { dissolved, } \\
\mu \mathrm{g} / \mathrm{L}\end{array}$ & $\begin{array}{l}\text { Praseodymium, } \\
\text { dissolved, } \\
\mu \mathrm{g} / \mathrm{L}\end{array}$ & $\begin{array}{c}\text { Rubidium, } \\
\text { dissolved, } \\
\mu \mathrm{g} / \mathrm{L}\end{array}$ & $\begin{array}{c}\text { Samarium, } \\
\text { dissolved, } \\
\mu \mathrm{g} / \mathrm{L}\end{array}$ \\
\hline$<0.1$ & 21.4 & 0.026 & 202 & 0.02 & 62 & $<0.2$ & $<0.01$ & 7.71 & $<0.01$ \\
\hline NA & NA & NA & NA & NA & NA & NA & NA & NA & NA \\
\hline$<0.1$ & 26.8 & 0.017 & 50 & 0.24 & 14 & $<0.2$ & 0.06 & 2.75 & 0.06 \\
\hline$<0.1$ & 18.6 & 0.017 & 156 & 0.04 & 70 & $<0.2$ & $<0.01$ & 8.98 & 0.02 \\
\hline NA & NA & NA & NA & NA & NA & NA & NA & NA & NA \\
\hline NA & NA & NA & NA & NA & NA & NA & NA & NA & NA \\
\hline NA & NA & NA & NA & NA & NA & NA & NA & NA & NA \\
\hline NA & 152 & $<0.010$ & 6 & NA & 27 & NA & NA & NA & NA \\
\hline NA & 4,800 & $<0.010$ & 2 & NA & 14 & NA & NA & NA & NA \\
\hline NA & 4,500 & $<0.010$ & 4 & NA & 18 & NA & NA & NA & NA \\
\hline NA & 4,500 & $<0.010$ & 4 & NA & 18 & NA & NA & NA & NA \\
\hline NA & 316 & $<0.010$ & 6 & NA & 2 & NA & NA & NA & NA \\
\hline NA & 2,770 & $<0.010$ & 9 & NA & 19 & NA & NA & NA & NA \\
\hline$<0.1$ & $<0.2$ & $<0.015$ & 2 & $<0.01$ & $<0.4$ & $<0.2$ & $<0.01$ & 0.04 & $<0.01$ \\
\hline NA & NA & NA & NA & NA & NA & NA & NA & NA & NA \\
\hline NA & $<0.2$ & $<0.010$ & $<0.4$ & NA & E,n0.03 & NA & NA & NA & NA \\
\hline
\end{tabular}


Appendix 4. Analytical data for leachate and groundwater samples associated with the biosolids-application area near Deer Trail, Colorado, 2005-Continued

[All leachate and groundwater chemical-concentration data are from filtered samples; associated data for matrix-spike recoveries are listed in appendix 5; sampling locations near Deer Trail are shown in figure 2; information for groundwater-sampling sites is provided in appendix 6; shaded analytes constitute a preliminary biosolids signature (summarized in table 3); MWRD properties are located near Deer Trail, Colorado, and are shown in figure 2; g, grams; L, liters; $\mu \mathrm{g} / \mathrm{L}$, micrograms per liter; $\%$, percent; $\mu \mathrm{S} / \mathrm{cm}$, microsiemens per centimeter at 25 degrees Celsius; $\mathrm{mg} / \mathrm{L}$, milligrams per liter; fresh, material obtained directly from wastewater treatment plant and processed inside laboratory; dried, material dewatered inside laboratory under forced-air conditions then ground to less than 150 micrometers prior to chemical analysis; MWRD, Metro Wastewater Reclamation District; WWTP, wastewater treatment plant in Denver, Colorado; $\mathrm{ft}$, feet below land surface; <, less than; NA, not analyzed; E, estimated by laboratory; n, less than the minimum reporting level; field aged, material obtained from surface of farm field near Deer Trail, Colorado, about 8 months after application; fresh field, material obtained from surface of farm field near Deer Trail, Colorado, less than one day after deposited; OBW, organic-free blank water (certified); USGS, U.S. Geological Survey]

\begin{tabular}{|c|c|c|c|c|c|c|}
\hline $\begin{array}{l}\text { Sample } \\
\text { type }\end{array}$ & $\begin{array}{l}\text { Source } \\
\text { material }\end{array}$ & $\begin{array}{c}\text { Source- } \\
\text { material or } \\
\text { sample-depth } \\
\text { description }\end{array}$ & $\begin{array}{l}\text { Sample } \\
\text { collection } \\
\text { date }\end{array}$ & $\begin{array}{c}\text { Site } \\
\text { description }\end{array}$ & $\begin{array}{c}\text { Scandium, } \\
\text { dissolved, } \\
\mu \mathrm{g} / \mathrm{L}\end{array}$ & $\begin{array}{c}\text { Selenium, } \\
\text { dissolved, } \\
\mu \mathrm{g} / \mathrm{L}\end{array}$ \\
\hline Leachate & Biosolids & $\begin{array}{l}\text { Archive of fresh, } \\
\text { dried (composite) }\end{array}$ & $\begin{array}{l}\text { 8/30/2005 leach of } \\
\text { 9/22/2004 biosolids }\end{array}$ & MWRD WWTP & 0.7 & 6 \\
\hline Replicate leachate & Biosolids & $\begin{array}{l}\text { Archive of fresh, } \\
\text { dried (composite) }\end{array}$ & $\begin{array}{l}\text { 8/30/2005 leach of } \\
\text { 9/22/2004 biosolids }\end{array}$ & MWRD WWTP & NA & NA \\
\hline Leachate & Biosolids & Field aged & $\begin{array}{l}\text { 8/30/2005 leached of } \\
5 / 31 / 2005 \text { field sample }\end{array}$ & $\begin{array}{l}\text { DC300; biosolids applied } \\
\text { between late September and } \\
\text { early October } 2004\end{array}$ & $<0.6$ & 5 \\
\hline Leachate & Biosolids & $\begin{array}{l}\text { Fresh, dried } \\
\text { (composite) }\end{array}$ & $\begin{array}{l}\text { 8/30/2005 leach of } \\
\text { January } 2005 \text { biosolids }\end{array}$ & MWRD WWTP & 0.6 & 5 \\
\hline Replicate leachate & Biosolids & $\begin{array}{l}\text { Fresh, dried } \\
\text { (composite) }\end{array}$ & $\begin{array}{l}\text { 8/30/2005 leach of } \\
\text { January } 2005 \text { biosolids }\end{array}$ & MWRD WWTP & NA & NA \\
\hline Leachate & Biosolids & $\begin{array}{l}\text { Fresh, moist } \\
\text { (composite) }\end{array}$ & $\begin{array}{l}\text { 8/30/2005 leach of } \\
8 / 23 / 2005 \text { biosolids }\end{array}$ & MWRD WWTP & NA & NA \\
\hline Replicate leachate & Biosolids & $\begin{array}{l}\text { Fresh, dried } \\
\text { (composite) }\end{array}$ & $\begin{array}{l}12 / 19 / 2005 \text { leach of } \\
\text { November } 2005 \text { biosolids }\end{array}$ & MWRD WWTP & NA & NA \\
\hline Leachate & Cow manure & Fresh field, dried & $\begin{array}{l}\text { 8/30/2005 leach of } \\
5 / 31 / 2005 \text { field sample }\end{array}$ & $\begin{array}{c}\text { South-2 (Cattle, } \\
\text { no farming, no biosolids) }\end{array}$ & NA & NA \\
\hline Groundwater & Alluvial aquifer & DTX1 at $20 \mathrm{ft}$ & $7 / 5 / 2005$ & MWRD North Property & NA & 15 \\
\hline Groundwater & Alluvial aquifer & DTX2 at $14 \mathrm{ft}$ & $7 / 5 / 2005$ & MWRD North Property & NA & 0.1 \\
\hline Groundwater & Alluvial aquifer & D6 at $19 \mathrm{ft}$ & $7 / 6 / 2005$ & MWRD Central Property & NA & 57 \\
\hline \multicolumn{2}{|c|}{ Replicate groundwater sample } & D6 at $19 \mathrm{ft}$ & $7 / 6 / 2005$ & MWRD Central Property & NA & 57 \\
\hline Groundwater & Alluvial aquifer & D17 at $16 \mathrm{ft}$ & $7 / 6 / 2005$ & MWRD Central Property & NA & 8 \\
\hline Groundwater & Alluvial aquifer & $\mathrm{D} 25$ at $18 \mathrm{ft}$ & $7 / 5 / 2005$ & MWRD Central Property & NA & 6 \\
\hline Leachate equipmen & t blank & OBW & $8 / 30 / 2005$ & USGS laboratory & $<0.6$ & $<1$ \\
\hline Leachate equipmen & t blank & OBW & $12 / 19 / 2005$ & USGS laboratory & NA & NA \\
\hline Field blank for grou & indwater samples & OBW & $7 / 6 / 2005$ & $\begin{array}{c}\text { MWRD } \\
\text { Central Property (D6) }\end{array}$ & NA & $<0.4$ \\
\hline
\end{tabular}


Appendix 4. Analytical data for leachate and groundwater samples associated with the biosolids-application area near Deer Trail, Colorado, 2005-Continued

[All leachate and groundwater chemical-concentration data are from filtered samples; associated data for matrix-spike recoveries are listed in appendix 5; sampling locations near Deer Trail are shown in figure 2; information for groundwater-sampling sites is provided in appendix 6; shaded analytes constitute a preliminary biosolids signature (summarized in table 3); MWRD properties are located near Deer Trail, Colorado, and are shown in figure 2; g, grams; L, liters; $\mu \mathrm{g} / \mathrm{L}$, micrograms per liter; $\%$, percent; $\mu \mathrm{S} / \mathrm{cm}$, microsiemens per centimeter at 25 degrees Celsius; $\mathrm{mg} / \mathrm{L}$, milligrams per liter; fresh, material obtained directly from wastewater treatment plant and processed inside laboratory; dried, material dewatered inside laboratory under forced-air conditions then ground to less than 150 micrometers prior to chemical analysis; MWRD, Metro Wastewater Reclamation District; WWTP, wastewater treatment plant in Denver, Colorado; $\mathrm{ft}$, feet below land surface; <, less than; NA, not analyzed; E, estimated by laboratory; $\mathrm{n}$, less than the minimum reporting level; field aged, material obtained from surface of farm field near Deer Trail, Colorado, about 8 months after application; fresh field, material obtained from surface of farm field near Deer Trail, Colorado, less than one day after deposited; OBW, organic-free blank water (certified); USGS, U.S. Geological Survey]

\begin{tabular}{|c|c|c|c|c|c|c|c|c|}
\hline $\begin{array}{c}\text { Silver, } \\
\text { dissolved, } \\
\mu \mathrm{g} / \mathrm{L}\end{array}$ & $\begin{array}{c}\text { Strontium, } \\
\text { dissolved, } \\
\mu \mathrm{g} / \mathrm{L}\end{array}$ & $\begin{array}{c}\text { Tantalum, } \\
\text { dissolved, } \\
\mu \mathrm{g} / \mathrm{L}\end{array}$ & $\begin{array}{c}\text { Terbium, } \\
\text { dissolved, } \\
\mu \mathrm{g} / \mathrm{L}\end{array}$ & $\begin{array}{c}\text { Thallium, } \\
\text { dissolved, } \\
\mu \mathrm{g} / \mathrm{L}\end{array}$ & $\begin{array}{c}\text { Thorium, } \\
\text { dissolved, } \\
\mu \mathrm{g} / \mathrm{L}\end{array}$ & $\begin{array}{c}\text { Thulium, } \\
\text { dissolved, } \\
\mu \mathrm{g} / \mathrm{L}\end{array}$ & $\begin{array}{c}\text { Titanium, } \\
\text { dissolved, } \\
\mu \mathrm{g} / \mathrm{L}\end{array}$ & $\begin{array}{c}\text { Tungsten, } \\
\text { dissolved } \\
\mu \mathrm{g} / \mathrm{L}\end{array}$ \\
\hline$<3$ & 11.9 & 0.1 & $<0.005$ & $<0.1$ & $<0.2$ & $<0.005$ & 4.6 & 6.6 \\
\hline NA & NA & NA & NA & NA & NA & NA & NA & NA \\
\hline$<3$ & 15.4 & 0.1 & 0.01 & $<0.1$ & $<0.2$ & 0.005 & 3.9 & 1.6 \\
\hline$<3$ & 23.2 & 0.1 & $<0.005$ & $<0.1$ & $<0.2$ & $<0.005$ & 5.6 & 5.2 \\
\hline NA & NA & NA & NA & NA & NA & NA & NA & NA \\
\hline NA & NA & NA & NA & NA & NA & NA & NA & NA \\
\hline NA & NA & NA & NA & NA & NA & NA & NA & NA \\
\hline NA & NA & NA & NA & NA & NA & NA & NA & NA \\
\hline$<0.4$ & 5,700 & NA & NA & NA & NA & NA & NA & $<1$ \\
\hline$<0.4$ & 5,090 & NA & NA & NA & NA & NA & NA & $<1$ \\
\hline$<1.4$ & 16,900 & NA & NA & NA & NA & NA & NA & $<3.5$ \\
\hline$<1.4$ & 16,600 & NA & NA & NA & NA & NA & NA & $<3.5$ \\
\hline$<0.2$ & 295 & NA & NA & NA & NA & NA & NA & $<0.5$ \\
\hline$<0.4$ & 3,450 & NA & NA & NA & NA & NA & NA & $<1$ \\
\hline$<3$ & 0.58 & 0.04 & $<0.005$ & $<0.1$ & $<0.2$ & $<0.005$ & $<0.5$ & $<0.5$ \\
\hline NA & NA & NA & NA & NA & NA & NA & NA & NA \\
\hline$<0.20$ & $<1.0$ & NA & NA & NA & NA & NA & NA & $<0.5$ \\
\hline
\end{tabular}


Appendix 4. Analytical data for leachate and groundwater samples associated with the biosolids-application area near Deer Trail, Colorado, 2005-Continued

[All leachate and groundwater chemical-concentration data are from filtered samples; associated data for matrix-spike recoveries are listed in appendix 5; sampling locations near Deer Trail are shown in figure 2; information for groundwater-sampling sites is provided in appendix 6; shaded analytes constitute a preliminary biosolids signature (summarized in table 3); MWRD properties are located near Deer Trail, Colorado, and are shown in figure 2; g, grams; L, liters; $\mu \mathrm{g} / \mathrm{L}$, micrograms per liter; \%, percent; $\mu \mathrm{S} / \mathrm{cm}$, microsiemens per centimeter at 25 degrees Celsius; $\mathrm{mg} / \mathrm{L}$, milligrams per liter; fresh, material obtained directly from wastewater treatment plant and processed inside laboratory; dried, material dewatered inside laboratory under forced-air conditions then ground to less than 150 micrometers prior to chemical analysis; MWRD, Metro Wastewater Reclamation District; WWTP, wastewater treatment plant in Denver, Colorado; $\mathrm{ft}$, feet below land surface; <, less than; NA, not analyzed; E, estimated by laboratory; n, less than the minimum reporting level; field aged, material obtained from surface of farm field near Deer Trail, Colorado, about 8 months after application; fresh field, material obtained from surface of farm field near Deer Trail, Colorado, less than one day after deposited; OBW, organic-free blank water (certified); USGS, U.S. Geological Survey]

\begin{tabular}{|c|c|c|c|c|c|c|c|}
\hline $\begin{array}{c}\text { Sample } \\
\text { type }\end{array}$ & $\begin{array}{l}\text { Source } \\
\text { material }\end{array}$ & $\begin{array}{c}\text { Source- } \\
\text { material or } \\
\text { sample-depth } \\
\text { description }\end{array}$ & $\begin{array}{c}\text { Sample } \\
\text { collection } \\
\text { date }\end{array}$ & $\begin{array}{c}\text { Site } \\
\text { description }\end{array}$ & $\begin{array}{c}\text { Uranium, } \\
\text { dissolved, } \\
\mu \mathrm{g} / \mathrm{L}\end{array}$ & $\begin{array}{c}\text { Vanadium, } \\
\text { dissolved, } \\
\mu \mathrm{g} / \mathrm{L}\end{array}$ & $\begin{array}{c}\text { Ytterbium, } \\
\text { dissolved, } \\
\mu \mathrm{g} / \mathrm{L}\end{array}$ \\
\hline Leachate & Biosolids & $\begin{array}{l}\text { Archive of fresh, } \\
\text { dried (composite) }\end{array}$ & $\begin{array}{l}\text { 8/30/2005 leach of } \\
9 / 22 / 2004 \text { biosolids }\end{array}$ & MWRD WWTP & 0.52 & 6.9 & $<0.005$ \\
\hline Replicate leachate & Biosolids & $\begin{array}{l}\text { Archive of fresh, } \\
\text { dried (composite) }\end{array}$ & $\begin{array}{l}\text { 8/30/2005 leach of } \\
9 / 22 / 2004 \text { biosolids }\end{array}$ & MWRD WWTP & NA & NA & NA \\
\hline Leachate & Biosolids & Field aged & $\begin{array}{l}\text { 8/30/2005 leached of } \\
5 / 31 / 2005 \text { field sample }\end{array}$ & $\begin{array}{c}\text { DC300; biosolids applied } \\
\text { between late September } \\
\text { and early October } 2004\end{array}$ & 0.33 & 7.8 & 0.03 \\
\hline Leachate & Biosolids & $\begin{array}{l}\text { Fresh, dried } \\
\text { (composite) }\end{array}$ & $\begin{array}{l}\text { 8/30/2005 leach of } \\
\text { January } 2005 \text { biosolids }\end{array}$ & MWRD WWTP & 0.42 & 4.2 & 0.005 \\
\hline Replicate leachate & Biosolids & $\begin{array}{l}\text { Fresh, dried } \\
\text { (composite) }\end{array}$ & $\begin{array}{l}\text { 8/30/2005 leach of } \\
\text { January } 2005 \text { biosolids }\end{array}$ & MWRD WWTP & NA & NA & NA \\
\hline Leachate & Biosolids & $\begin{array}{l}\text { Fresh, moist } \\
\text { (composite) }\end{array}$ & $\begin{array}{l}\text { 8/30/2005 leach of } \\
8 / 23 / 2005 \text { biosolids }\end{array}$ & MWRD WWTP & NA & NA & NA \\
\hline Replicate leachate & Biosolids & $\begin{array}{l}\text { Fresh, dried } \\
\text { (composite) }\end{array}$ & $\begin{array}{c}\text { 12/19/2005 leach of } \\
\text { November } 2005 \text { biosolids }\end{array}$ & MWRD WWTP & NA & NA & NA \\
\hline Leachate & Cow manure & Fresh field, dried & $\begin{array}{l}\text { 8/30/2005 leach of } \\
5 / 31 / 2005 \text { field sample }\end{array}$ & $\begin{array}{c}\text { South-2 (Cattle, } \\
\text { no farming, no biosolids) }\end{array}$ & NA & NA & NA \\
\hline Groundwater & Alluvial aquifer & DTX1 at $20 \mathrm{ft}$ & $7 / 5 / 2005$ & MWRD North Property & 47 & NA & NA \\
\hline Groundwater & Alluvial aquifer & DTX2 at $14 \mathrm{ft}$ & $7 / 5 / 2005$ & MWRD North Property & 31 & NA & NA \\
\hline Groundwater & Alluvial aquifer & D6 at $19 \mathrm{ft}$ & $7 / 6 / 2005$ & MWRD Central Property & 160 & NA & NA \\
\hline \multicolumn{2}{|c|}{ Replicate groundwater sample } & D6 at $19 \mathrm{ft}$ & $7 / 6 / 2005$ & MWRD Central Property & 160 & NA & NA \\
\hline Groundwater & Alluvial aquifer & D17 at $16 \mathrm{ft}$ & $7 / 6 / 2005$ & MWRD Central Property & 4.5 & NA & NA \\
\hline Groundwater & Alluvial aquifer & $\mathrm{D} 25$ at $18 \mathrm{ft}$ & $7 / 5 / 2005$ & MWRD Central Property & 37 & NA & NA \\
\hline \multicolumn{2}{|c|}{ Leachate equipment blank } & OBW & $8 / 30 / 2005$ & USGS laboratory & $<0.1$ & $<0.5$ & $<0.005$ \\
\hline \multirow{2}{*}{\multicolumn{2}{|c|}{$\begin{array}{l}\text { Leachate equipment blank } \\
\text { Field blank for groundwater samples }\end{array}$}} & OBW & $12 / 19 / 2005$ & USGS laboratory & NA & NA & NA \\
\hline & & OBW & $7 / 6 / 2005$ & $\begin{array}{c}\text { MWRD } \\
\text { Central Property (D6) }\end{array}$ & $<0.04$ & NA & NA \\
\hline
\end{tabular}


Appendix 4. Analytical data for leachate and groundwater samples associated with the biosolids-application area near Deer Trail, Colorado, 2005-Continued

[All leachate and groundwater chemical-concentration data are from filtered samples; associated data for matrix-spike recoveries are listed in appendix 5; sampling locations near Deer Trail are shown in figure 2; information for groundwater-sampling sites is provided in appendix 6; shaded analytes constitute a preliminary biosolids signature (summarized in table 3); MWRD properties are located near Deer Trail, Colorado, and are shown in figure 2; g, grams; L, liters; $\mu \mathrm{g} / \mathrm{L}$, micrograms per liter; $\%$, percent; $\mu \mathrm{S} / \mathrm{cm}$, microsiemens per centimeter at 25 degrees Celsius; $\mathrm{mg} / \mathrm{L}$, milligrams per liter; fresh, material obtained directly from wastewater treatment plant and processed inside laboratory; dried, material dewatered inside laboratory under forced-air conditions then ground to less than 150 micrometers prior to chemical analysis; MWRD, Metro Wastewater Reclamation District; WWTP, wastewater treatment plant in Denver, Colorado; $\mathrm{ft}$, feet below land surface; <, less than; NA, not analyzed; E, estimated by laboratory; $\mathrm{n}$, less than the minimum reporting level; field aged, material obtained from surface of farm field near Deer Trail, Colorado, about 8 months after application; fresh field, material obtained from surface of farm field near Deer Trail, Colorado, less than one day after deposited; OBW, organic-free blank water (certified); USGS, U.S. Geological Survey]

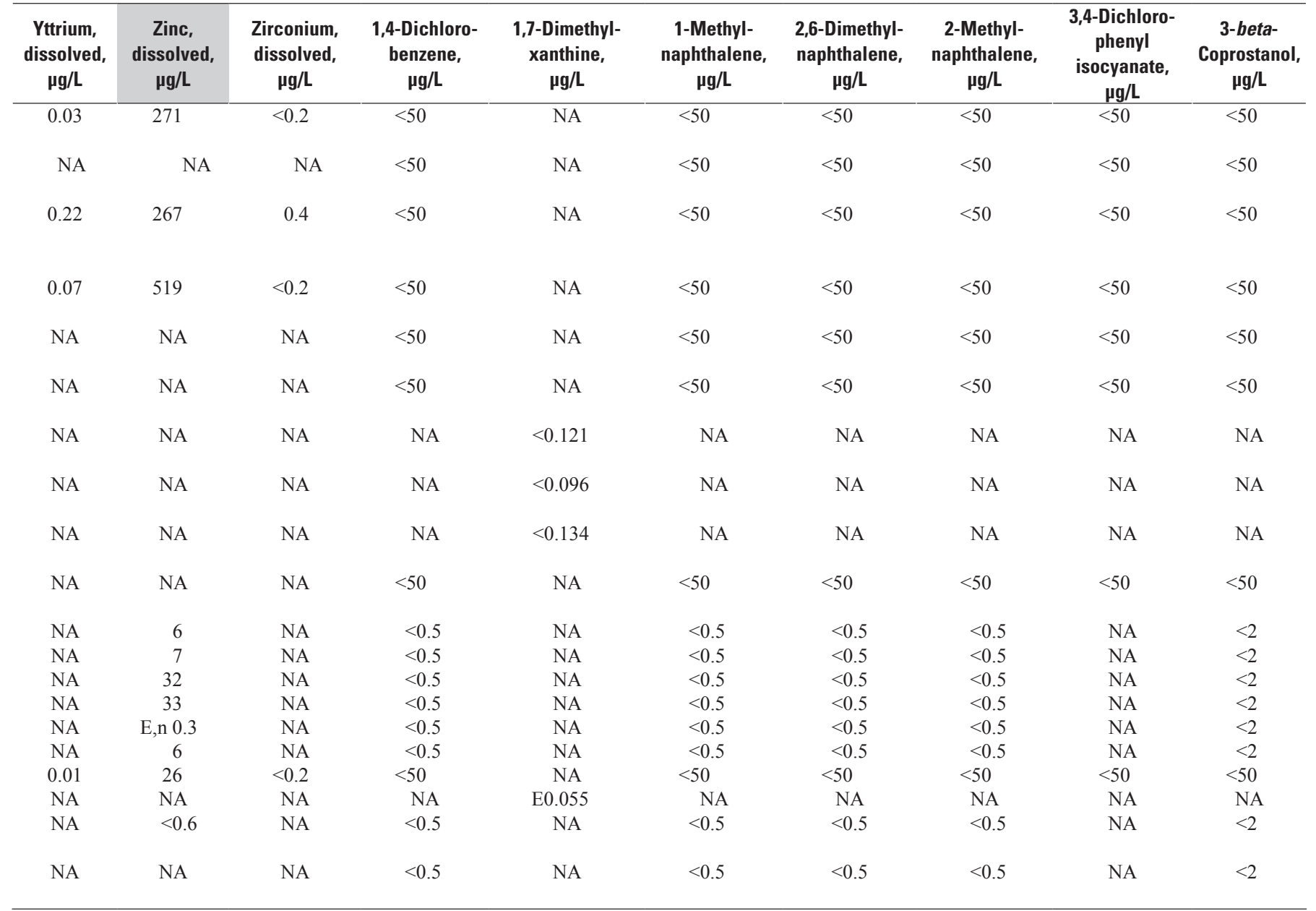


Appendix 4. Analytical data for leachate and groundwater samples associated with the biosolids-application area near Deer Trail, Colorado, 2005-Continued

[All leachate and groundwater chemical-concentration data are from filtered samples; associated data for matrix-spike recoveries are listed in appendix 5; sampling locations near Deer Trail are shown in figure 2; information for groundwater-sampling sites is provided in appendix 6; shaded analytes constitute a preliminary biosolids signature (summarized in table 3); MWRD properties are located near Deer Trail, Colorado, and are shown in figure 2; g, grams; L, liters; $\mu \mathrm{g} / \mathrm{L}$, micrograms per liter; $\%$, percent; $\mu \mathrm{S} / \mathrm{cm}$, microsiemens per centimeter at 25 degrees Celsius; $\mathrm{mg} / \mathrm{L}$, milligrams per liter; fresh, material obtained directly from wastewater treatment plant and processed inside laboratory; dried, material dewatered inside laboratory under forced-air conditions then ground to less than 150 micrometers prior to chemical analysis; MWRD, Metro Wastewater Reclamation District; WWTP, wastewater treatment plant in Denver, Colorado; $\mathrm{ft}$, feet below land surface; <, less than; NA, not analyzed; E, estimated by laboratory; $\mathrm{n}$, less than the minimum reporting level; field aged, material obtained from surface of farm field near Deer Trail, Colorado, about 8 months after application; fresh field, material obtained from surface of farm field near Deer Trail, Colorado, less than one day after deposited; OBW, organic-free blank water (certified); USGS, U.S. Geological Survey]

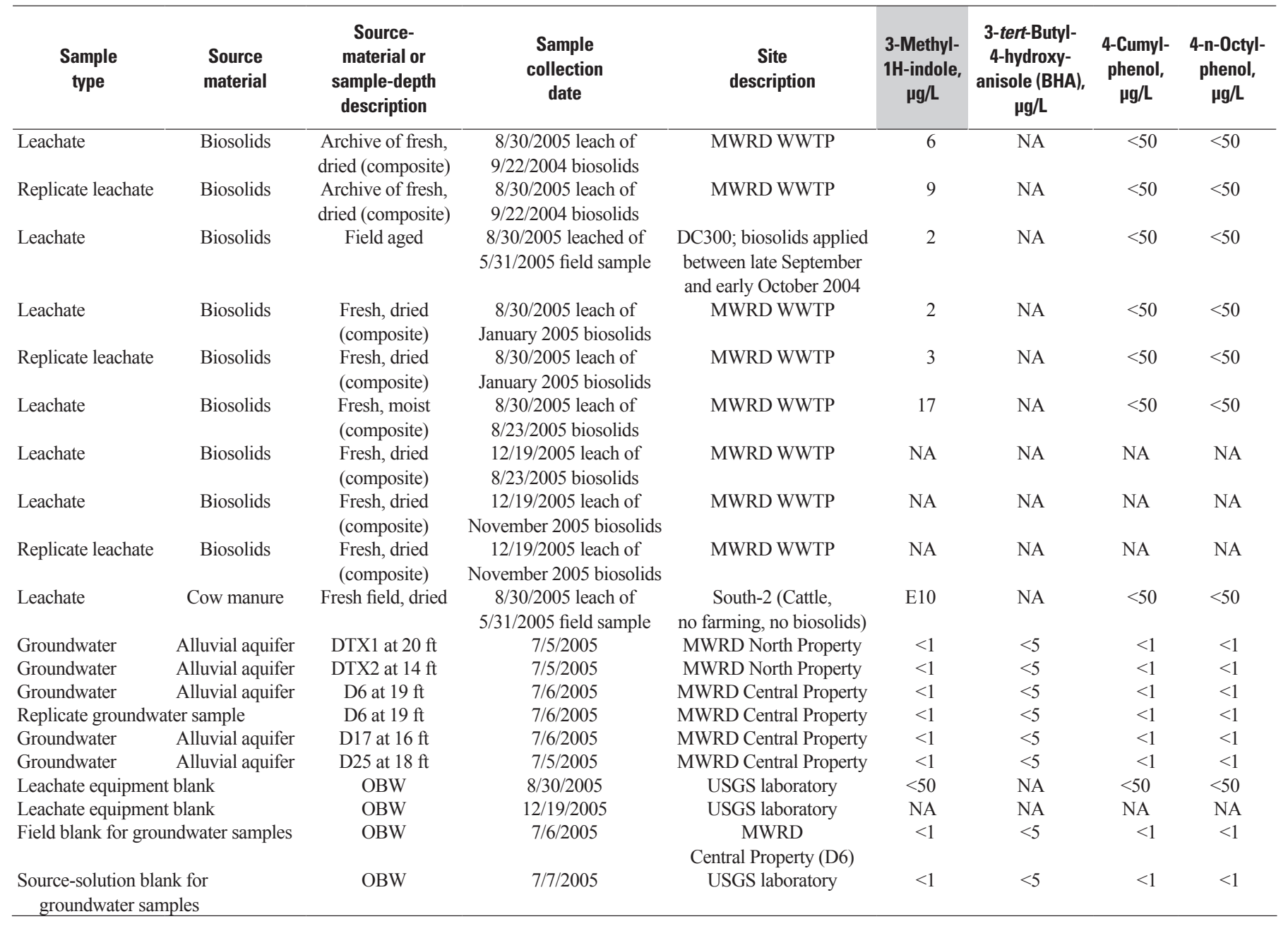


Appendix 4. Analytical data for leachate and groundwater samples associated with the biosolids-application area near Deer Trail, Colorado, 2005-Continued

[All leachate and groundwater chemical-concentration data are from filtered samples; associated data for matrix-spike recoveries are listed in appendix 5; sampling locations near Deer Trail are shown in figure 2; information for groundwater-sampling sites is provided in appendix 6; shaded analytes constitute a preliminary biosolids signature (summarized in table 3); MWRD properties are located near Deer Trail, Colorado, and are shown in figure 2; g, grams; L, liters; $\mu \mathrm{g} / \mathrm{L}$, micrograms per liter; $\%$, percent; $\mu \mathrm{S} / \mathrm{cm}$, microsiemens per centimeter at 25 degrees Celsius; $\mathrm{mg} / \mathrm{L}$, milligrams per liter; fresh, material obtained directly from wastewater treatment plant and processed inside laboratory; dried, material dewatered inside laboratory under forced-air conditions then ground to less than 150 micrometers prior to chemical analysis; MWRD, Metro Wastewater Reclamation District; WWTP, wastewater treatment plant in Denver, Colorado; $\mathrm{ft}$, feet below land surface; <, less than; NA, not analyzed; E, estimated by laboratory; $\mathrm{n}$, less than the minimum reporting level; field aged, material obtained from surface of farm field near Deer Trail, Colorado, about 8 months after application; fresh field, material obtained from surface of farm field near Deer Trail, Colorado, less than one day after deposited; OBW, organic-free blank water (certified); USGS, U.S. Geological Survey]

\begin{tabular}{|c|c|c|c|c|c|c|c|c|c|}
\hline $\begin{array}{c}\text { 4-Nonyl- } \\
\text { phenol (sum } \\
\text { of all isomers), } \\
\mu \mathrm{g} / \mathrm{L} \\
\end{array}$ & $\begin{array}{c}\text { 4-Nonyl-phenol } \\
\text { diethoxylate (sum } \\
\text { of all isomers) } \\
\text { (NPE02), } \\
\mu \mathrm{g} / \mathrm{L}\end{array}$ & $\begin{array}{c}\text { 4-Nonyl-phenol } \\
\text { monoethoxylate } \\
\text { (sum of all } \\
\text { isomers) (NPEO1), } \\
\mu \mathrm{g} / \mathrm{L}\end{array}$ & $\begin{array}{l}\text { 4-tert-0ctyl- } \\
\text { phenol, } \\
\mu \mathrm{g} / \mathrm{L}\end{array}$ & $\begin{array}{l}\text { 4-tert-0ctyl- } \\
\text { phenol } \\
\text { diethoxylate } \\
\text { (OPEO2), } \\
\mu \mathrm{g} / \mathrm{L} \\
\end{array}$ & $\begin{array}{c}\text { 4-tert-0ctyl- } \\
\text { phenol } \\
\text { monoethoxylate } \\
\text { (OPE01), } \\
\mu \mathrm{g} / \mathrm{L} \\
\end{array}$ & $\begin{array}{c}\text { 5-Methyl- } \\
\text { 1H-benzotriazole, } \\
\mu \mathrm{g} / \mathrm{L}\end{array}$ & $\begin{array}{c}\text { 9,10-Anthra- } \\
\text { quinone, } \\
\mu \mathrm{g} / \mathrm{L}\end{array}$ & $\begin{array}{c}\text { Aceta- } \\
\text { minophen, } \\
\mu \mathrm{g} / \mathrm{L}\end{array}$ & $\begin{array}{c}\text { Aceto- } \\
\text { phenone, } \\
\mu \mathrm{g} / \mathrm{L}\end{array}$ \\
\hline E82 & $<50$ & $<50$ & $<50$ & $<<50$ & $<50$ & $<50$ & $<50$ & NA & 31 \\
\hline E91 & $<50$ & $<50$ & $<50$ & $<50$ & $<50$ & $<50$ & $<50$ & NA & 33 \\
\hline E170 & $<50$ & $<50$ & $<50$ & $<50$ & $<50$ & $<50$ & $<50$ & NA & $<50$ \\
\hline E160 & $<50$ & $<50$ & $<50$ & $<50$ & $<50$ & $<50$ & $<50$ & NA & $<50$ \\
\hline E40 & $<50$ & $<50$ & $<50$ & $<50$ & $<50$ & $<50$ & $<50$ & $\mathrm{NA}$ & 33 \\
\hline NA & NA & NA & NA & NA & NA & NA & NA & 0.036 & NA \\
\hline E38 & $<50$ & $<50$ & $<50$ & $<50$ & $<50$ & $<50$ & $<50$ & NA & $<50$ \\
\hline$<5$ & $<5$ & NA & $<1$ & $<1$ & $<1$ & $<2$ & $<0.5$ & NA & $<0.5$ \\
\hline$<5$ & $<5$ & NA & $<1$ & $<1$ & $<1$ & $<2$ & $<0.5$ & NA & $<0.5$ \\
\hline$<5$ & $<5$ & NA & $<1$ & $<1$ & $<1$ & NA & $<0.5$ & NA & $<0.5$ \\
\hline$<5$ & $<5$ & NA & $<1$ & E0.06 & $<1$ & NA & NA & NA & $<0.5$ \\
\hline$<5$ & $<5$ & NA & $<1$ & $<1$ & $<1$ & NA & $<0.5$ & NA & $<0.5$ \\
\hline$<5$ & $<5$ & NA & $<1$ & $<1$ & $<1$ & $<2$ & $<0.5$ & NA & E,n0.21 \\
\hline$<50$ & $<50$ & $<50$ & $<50$ & $<50$ & $<50$ & $<50$ & $<50$ & NA & $<50$ \\
\hline NA & NA & NA & NA & NA & NA & NA & NA & $<0.024$ & NA \\
\hline
\end{tabular}


Appendix 4. Analytical data for leachate and groundwater samples associated with the biosolids-application area near Deer Trail, Colorado, 2005-Continued

[All leachate and groundwater chemical-concentration data are from filtered samples; associated data for matrix-spike recoveries are listed in appendix 5; sampling locations near Deer Trail are shown in figure 2; information for groundwater-sampling sites is provided in appendix 6; shaded analytes constitute a preliminary biosolids signature (summarized in table 3); MWRD properties are located near Deer Trail, Colorado, and are shown in figure 2; g, grams; L, liters; $\mu \mathrm{g} / \mathrm{L}$, micrograms per liter; $\%$, percent; $\mu \mathrm{S} / \mathrm{cm}$, microsiemens per centimeter at 25 degrees Celsius; $\mathrm{mg} / \mathrm{L}$, milligrams per liter; fresh, material obtained directly from wastewater treatment plant and processed inside laboratory; dried, material dewatered inside laboratory under forced-air conditions then ground to less than 150 micrometers prior to chemical analysis; MWRD, Metro Wastewater Reclamation District; WWTP, wastewater treatment plant in Denver, Colorado; $\mathrm{ft}$, feet below land surface; <, less than; NA, not analyzed; E, estimated by laboratory; $\mathrm{n}$, less than the minimum reporting level; field aged, material obtained from surface of farm field near Deer Trail, Colorado, about 8 months after application; fresh field, material obtained from surface of farm field near Deer Trail, Colorado, less than one day after deposited; OBW, organic-free blank water (certified); USGS, U.S. Geological Survey]

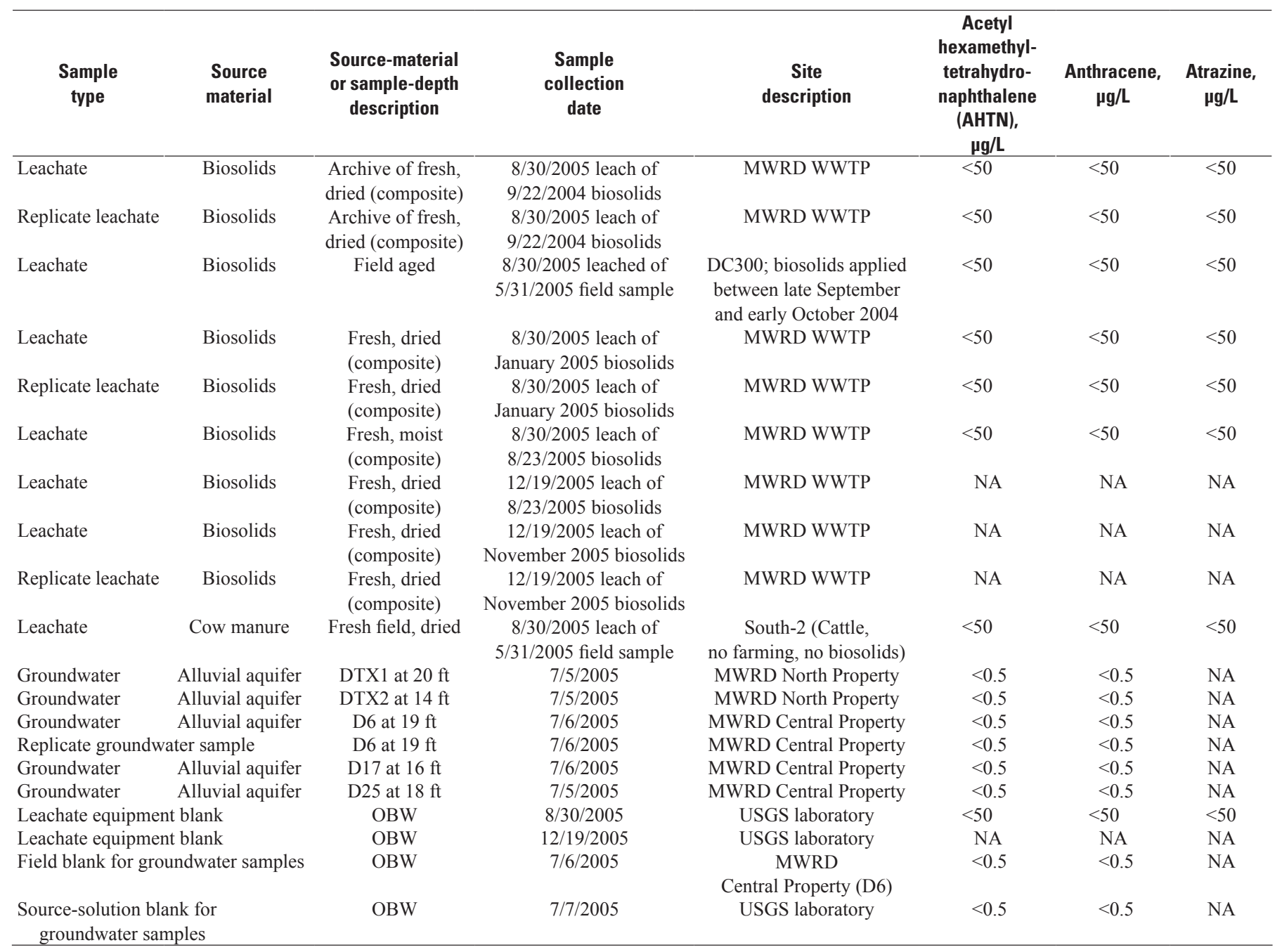


Appendix 4. Analytical data for leachate and groundwater samples associated with the biosolids-application area near Deer Trail, Colorado, 2005-Continued

[All leachate and groundwater chemical-concentration data are from filtered samples; associated data for matrix-spike recoveries are listed in appendix 5; sampling locations near Deer Trail are shown in figure 2; information for groundwater-sampling sites is provided in appendix 6; shaded analytes constitute a preliminary biosolids signature (summarized in table 3); MWRD properties are located near Deer Trail, Colorado, and are shown in figure 2; g, grams; L, liters; $\mu \mathrm{g} / \mathrm{L}$, micrograms per liter; $\%$, percent; $\mu \mathrm{S} / \mathrm{cm}$, microsiemens per centimeter at 25 degrees Celsius; $\mathrm{mg} / \mathrm{L}$, milligrams per liter; fresh, material obtained directly from wastewater treatment plant and processed inside laboratory; dried, material dewatered inside laboratory under forced-air conditions then ground to less than 150 micrometers prior to chemical analysis; MWRD, Metro Wastewater Reclamation District; WWTP, wastewater treatment plant in Denver, Colorado; $\mathrm{ft}$, feet below land surface; <, less than; NA, not analyzed; E, estimated by laboratory; $\mathrm{n}$, less than the minimum reporting level; field aged, material obtained from surface of farm field near Deer Trail, Colorado, about 8 months after application; fresh field, material obtained from surface of farm field near Deer Trail, Colorado, less than one day after deposited; OBW, organic-free blank water (certified); USGS, U.S. Geological Survey]

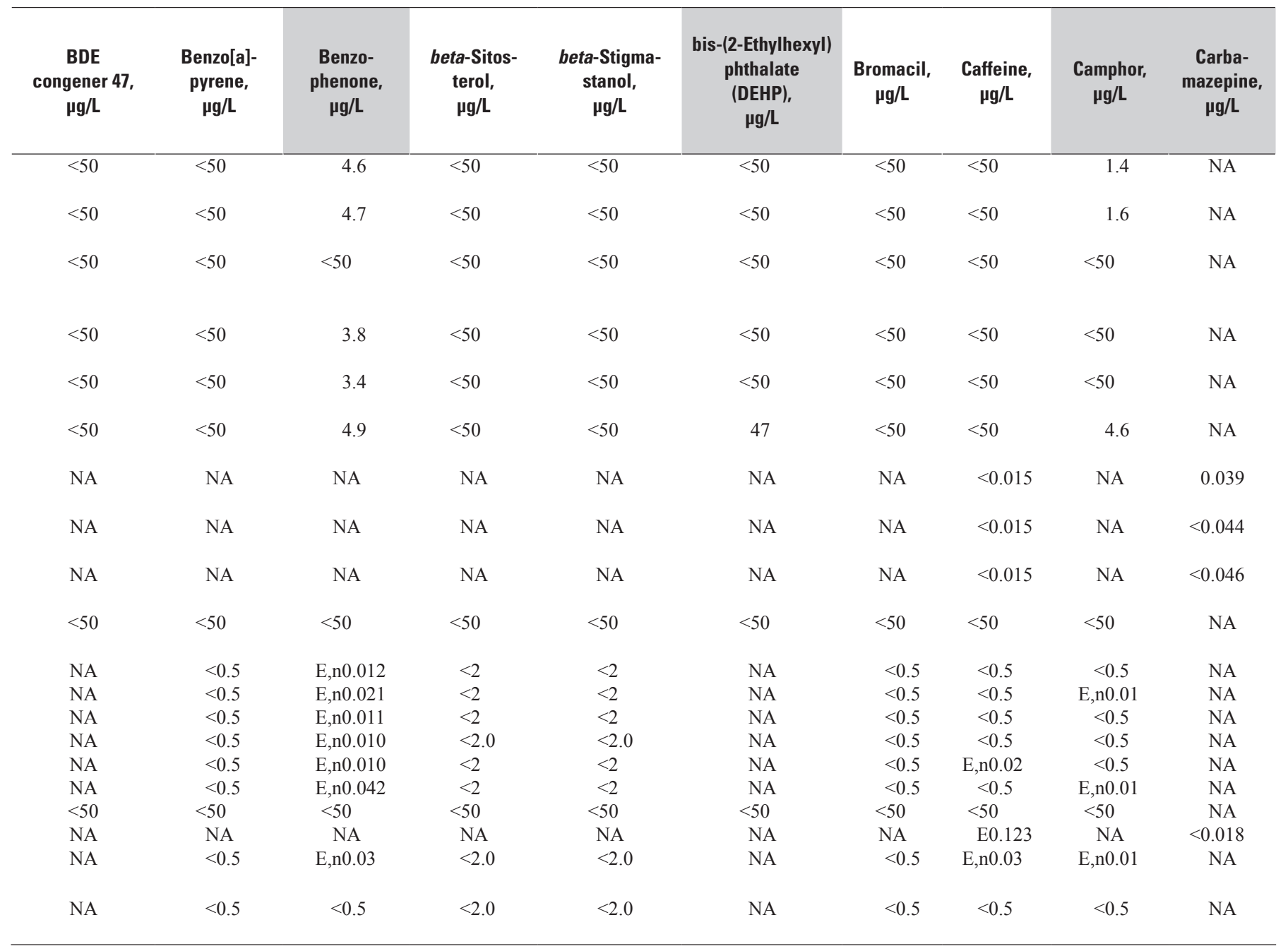


Appendix 4. Analytical data for leachate and groundwater samples associated with the biosolids-application area near Deer Trail, Colorado, 2005-Continued

[All leachate and groundwater chemical-concentration data are from filtered samples; associated data for matrix-spike recoveries are listed in appendix 5; sampling locations near Deer Trail are shown in figure 2; information for groundwater-sampling sites is provided in appendix 6; shaded analytes constitute a preliminary biosolids signature (summarized in table 3); MWRD properties are located near Deer Trail, Colorado, and are shown in figure 2; g, grams; L, liters; $\mu \mathrm{g} / \mathrm{L}$, micrograms per liter; $\%$, percent; $\mu \mathrm{S} / \mathrm{cm}$, microsiemens per centimeter at 25 degrees Celsius; $\mathrm{mg} / \mathrm{L}$, milligrams per liter; fresh, material obtained directly from wastewater treatment plant and processed inside laboratory; dried, material dewatered inside laboratory under forced-air conditions then ground to less than 150 micrometers prior to chemical analysis; MWRD, Metro Wastewater Reclamation District; WWTP, wastewater treatment plant in Denver, Colorado; $\mathrm{ft}$, feet below land surface; <, less than; NA, not analyzed; E, estimated by laboratory; $\mathrm{n}$, less than the minimum reporting level; field aged, material obtained from surface of farm field near Deer Trail, Colorado, about 8 months after application; fresh field, material obtained from surface of farm field near Deer Trail, Colorado, less than one day after deposited; OBW, organic-free blank water (certified); USGS, U.S. Geological Survey]

\begin{tabular}{|c|c|c|c|c|c|c|c|}
\hline $\begin{array}{l}\text { Sample } \\
\text { type }\end{array}$ & $\begin{array}{l}\text { Source } \\
\text { material }\end{array}$ & $\begin{array}{l}\text { Source-material } \\
\text { or sample-depth } \\
\text { description }\end{array}$ & $\begin{array}{l}\text { Sample } \\
\text { collection } \\
\text { date }\end{array}$ & $\begin{array}{c}\text { Site } \\
\text { description }\end{array}$ & $\begin{array}{c}\text { Carbaryl, } \\
\mu \mathrm{g} / \mathrm{L}\end{array}$ & $\begin{array}{c}\text { Carbazole, } \\
\mu \mathrm{gg} / \mathrm{L}\end{array}$ & $\begin{array}{c}\text { Chlorpyrifos, } \\
\mu \mathrm{\mu g} / \mathrm{L}\end{array}$ \\
\hline Leachate & Biosolids & $\begin{array}{l}\text { Archive of fresh, } \\
\text { dried (composite) }\end{array}$ & $\begin{array}{l}\text { 8/30/2005 leach of } \\
9 / 22 / 2004 \text { biosolids }\end{array}$ & MWRD WWTP & $<50$ & $<50$ & $<50$ \\
\hline Replicate leachate & Biosolids & $\begin{array}{l}\text { Archive of fresh, } \\
\text { dried (composite) }\end{array}$ & $\begin{array}{l}\text { 8/30/2005 leach of } \\
\text { 9/22/2004 biosolids }\end{array}$ & MWRD WWTP & $<50$ & $<50$ & $<50$ \\
\hline Leachate & Biosolids & Field aged & $\begin{array}{l}\text { 8/30/2005 leached of } \\
5 / 31 / 2005 \text { field sample }\end{array}$ & $\begin{array}{l}\text { DC300; biosolids applied } \\
\text { between late September } \\
\text { and early October } 2004\end{array}$ & $<50$ & $<50$ & $<50$ \\
\hline Leachate & Biosolids & $\begin{array}{l}\text { Fresh, dried } \\
\text { (composite) }\end{array}$ & $\begin{array}{l}\text { 8/30/2005 leach of } \\
\text { January } 2005 \text { biosolids }\end{array}$ & MWRD WWTP & $<50$ & $<50$ & $<50$ \\
\hline Replicate leachate & Biosolids & $\begin{array}{l}\text { Fresh, dried } \\
\text { (composite) }\end{array}$ & $\begin{array}{l}\text { 8/30/2005 leach of } \\
\text { January } 2005 \text { biosolids }\end{array}$ & MWRD WWTP & $<50$ & $<50$ & $<50$ \\
\hline Leachate & Biosolids & $\begin{array}{l}\text { Fresh, moist } \\
\text { (composite) }\end{array}$ & $\begin{array}{l}\text { 8/30/2005 leach of } \\
8 / 23 / 2005 \text { biosolids }\end{array}$ & MWRD WWTP & $<50$ & $<50$ & $<50$ \\
\hline Leachate & Cow manure & Fresh field, dried & $\begin{array}{l}\text { 8/30/2005 leach of } \\
5 / 31 / 2005 \text { field sample }\end{array}$ & $\begin{array}{c}\text { South-2 (Cattle, } \\
\text { no farming, no biosolids) }\end{array}$ & $<50$ & $<50$ & $<50$ \\
\hline Groundwater & Alluvial aquifer & DTX1 at $20 \mathrm{ft}$ & $7 / 5 / 2005$ & MWRD North Property & $<1$ & $<0.5$ & $<0.5$ \\
\hline Groundwater & Alluvial aquifer & DTX2 at $14 \mathrm{ft}$ & $7 / 5 / 2005$ & MWRD North Property & $<1$ & $<0.5$ & $<0.5$ \\
\hline Groundwater & Alluvial aquifer & D6 at $19 \mathrm{ft}$ & $7 / 6 / 2005$ & MWRD Central Property & $<1$ & $<0.5$ & $<0.5$ \\
\hline \multicolumn{2}{|c|}{ Replicate groundwater sample } & D6 at $19 \mathrm{ft}$ & $7 / 6 / 2005$ & MWRD Central Property & $<1$ & $<0.5$ & $<0.5$ \\
\hline Groundwater & Alluvial aquifer & $\mathrm{D} 17$ at $16 \mathrm{ft}$ & $7 / 6 / 2005$ & MWRD Central Property & $<1$ & $<0.5$ & $<0.5$ \\
\hline Groundwater & Alluvial aquifer & $\mathrm{D} 25$ at $18 \mathrm{ft}$ & $7 / 5 / 2005$ & MWRD Central Property & $<1$ & $<0.5$ & $<0.5$ \\
\hline \multicolumn{2}{|c|}{ Leachate equipment blank } & OBW & $8 / 30 / 2005$ & USGS laboratory & $<50$ & $<50$ & $<50$ \\
\hline \multirow{2}{*}{\multicolumn{2}{|c|}{$\begin{array}{l}\text { Leachate equipment blank } \\
\text { Field blank for groundwater samples }\end{array}$}} & OBW & $12 / 19 / 2005$ & USGS laboratory & NA & NA & NA \\
\hline & & OBW & $7 / 6 / 2005$ & $\begin{array}{c}\text { MWRD } \\
\text { Central Property (D6) }\end{array}$ & $<1$ & $<0.5$ & $<0.5$ \\
\hline
\end{tabular}


Appendix 4. Analytical data for leachate and groundwater samples associated with the biosolids-application area near Deer Trail, Colorado, 2005-Continued

[All leachate and groundwater chemical-concentration data are from filtered samples; associated data for matrix-spike recoveries are listed in appendix 5; sampling locations near Deer Trail are shown in figure 2; information for groundwater-sampling sites is provided in appendix 6; shaded analytes constitute a preliminary biosolids signature (summarized in table 3); MWRD properties are located near Deer Trail, Colorado, and are shown in figure 2; g, grams; L, liters; $\mu \mathrm{g} / \mathrm{L}$, micrograms per liter; $\%$, percent; $\mu \mathrm{S} / \mathrm{cm}$, microsiemens per centimeter at 25 degrees Celsius; $\mathrm{mg} / \mathrm{L}$, milligrams per liter; fresh, material obtained directly from wastewater treatment plant and processed inside laboratory; dried, material dewatered inside laboratory under forced-air conditions then ground to less than 150 micrometers prior to chemical analysis; MWRD, Metro Wastewater Reclamation District; WWTP, wastewater treatment plant in Denver, Colorado; $\mathrm{ft}$, feet below land surface; <, less than; NA, not analyzed; E, estimated by laboratory; $\mathrm{n}$, less than the minimum reporting level; field aged, material obtained from surface of farm field near Deer Trail, Colorado, about 8 months after application; fresh field, material obtained from surface of farm field near Deer Trail, Colorado, less than one day after deposited; OBW, organic-free blank water (certified); USGS, U.S. Geological Survey]

\begin{tabular}{|c|c|c|c|c|c|c|c|c|c|c|}
\hline $\begin{array}{c}\text { Cholesterol, } \\
\mu \mathrm{g} / \mathrm{L}\end{array}$ & $\begin{array}{c}\text { Codeine, } \\
\mu \mathrm{g} / \mathrm{L}\end{array}$ & $\begin{array}{c}\text { Cotinine, } \\
\mu \mathrm{g} / \mathrm{L}\end{array}$ & $\begin{array}{c}\text { Dehydro- } \\
\text { nifedipine, } \\
\mu \mathrm{g} / \mathrm{L}\end{array}$ & $\begin{array}{c}\text { Diazinon, } \\
\mu \mathrm{g} / \mathrm{L}\end{array}$ & $\begin{array}{c}\text { Dichlorvos, } \\
\mu \mathrm{g} / \mathrm{L}\end{array}$ & $\begin{array}{c}\text { N,N-diethyl- } \\
\text { metatoluamide } \\
\text { (DEET), } \\
\mu \mathrm{g} / \mathrm{L}\end{array}$ & $\begin{array}{c}\text { Diethyl- } \\
\text { phthalate, } \\
\mu \mathrm{g} / \mathrm{L}\end{array}$ & $\begin{array}{c}\text { Diltiazem, } \\
\mu \mathrm{g} / \mathrm{L}\end{array}$ & $\begin{array}{c}\text { Diphen- } \\
\text { hydramine, } \\
\mu \mathrm{g} / \mathrm{L}\end{array}$ & $\begin{array}{c}\text { d-Limonene, } \\
\mu \mathrm{g} / \mathrm{L}\end{array}$ \\
\hline$<50$ & NA & $<50$ & NA & $<50$ & $<50$ & $<50$ & 31 & NA & NA & $<50$ \\
\hline$<50$ & NA & $<50$ & NA & $<50$ & $<50$ & $<50$ & $<50$ & NA & NA & $<50$ \\
\hline$<50$ & NA & $<50$ & NA & $<50$ & $<50$ & $<50$ & $<50$ & NA & NA & $<50$ \\
\hline$<50$ & NA & $<50$ & NA & $<50$ & $<50$ & $<50$ & $<50$ & NA & NA & $<50$ \\
\hline$<50$ & NA & $<50$ & NA & $<50$ & $<50$ & $<50$ & $<50$ & NA & NA & $<50$ \\
\hline NA & $<0.022$ & $<0.042$ & $<0.022$ & NA & NA & NA & NA & $<0.018$ & $<0.023$ & NA \\
\hline$<50$ & NA & $<50$ & NA & $<50$ & $<50$ & $<50$ & $<50$ & NA & NA & $<50$ \\
\hline$<2$ & NA & $<1$ & NA & $<0.5$ & NA & E,n0.01 & NA & NA & NA & $<0.5$ \\
\hline$<2$ & NA & $<1$ & NA & $<0.5$ & NA & E,n0.33 & NA & NA & NA & $<0.5$ \\
\hline$<2$ & NA & $<1$ & NA & $<0.5$ & NA & $<0.5$ & NA & NA & NA & $<0.5$ \\
\hline$<2$ & NA & $<1$ & NA & $<0.5$ & NA & E,n0.01 & NA & NA & NA & $<0.5$ \\
\hline$<2$ & NA & $<1$ & NA & $<0.5$ & NA & E,n0.02 & NA & NA & NA & $<0.5$ \\
\hline$<2$ & NA & $<1$ & NA & $<0.5$ & NA & E,n0.02 & NA & NA & NA & $<0.5$ \\
\hline$<50$ & NA & $<50$ & NA & $<50$ & $<50$ & $<50$ & 27 & NA & NA & $<50$ \\
\hline NA & $<0.022$ & $<0.028$ & $<0.022$ & NA & NA & NA & NA & $<0.018$ & $<0.023$ & NA \\
\hline$<2$ & NA & $<1$ & NA & $<0.5$ & NA & 0.53 & NA & NA & NA & $<0.5$ \\
\hline
\end{tabular}


Appendix 4. Analytical data for leachate and groundwater samples associated with the biosolids-application area near Deer Trail, Colorado, 2005-Continued

[All leachate and groundwater chemical-concentration data are from filtered samples; associated data for matrix-spike recoveries are listed in appendix 5; sampling locations near Deer Trail are shown in figure 2; information for groundwater-sampling sites is provided in appendix 6; shaded analytes constitute a preliminary biosolids signature (summarized in table 3); MWRD properties are located near Deer Trail, Colorado, and are shown in figure 2; g, grams; L, liters; $\mu \mathrm{g} / \mathrm{L}$, micrograms per liter; $\%$, percent; $\mu \mathrm{S} / \mathrm{cm}$, microsiemens per centimeter at 25 degrees Celsius; $\mathrm{mg} / \mathrm{L}$, milligrams per liter; fresh, material obtained directly from wastewater treatment plant and processed inside laboratory; dried, material dewatered inside laboratory under forced-air conditions then ground to less than 150 micrometers prior to chemical analysis; MWRD, Metro Wastewater Reclamation District; WWTP, wastewater treatment plant in Denver, Colorado; $\mathrm{ft}$, feet below land surface; <, less than; NA, not analyzed; E, estimated by laboratory; n, less than the minimum reporting level; field aged, material obtained from surface of farm field near Deer Trail, Colorado, about 8 months after application; fresh field, material obtained from surface of farm field near Deer Trail, Colorado, less than one day after deposited; OBW, organic-free blank water (certified); USGS, U.S. Geological Survey]

\begin{tabular}{|c|c|c|c|c|c|c|}
\hline $\begin{array}{l}\text { Sample } \\
\text { type }\end{array}$ & $\begin{array}{l}\text { Source } \\
\text { material }\end{array}$ & $\begin{array}{c}\text { Source- } \\
\text { material or } \\
\text { sample-depth } \\
\text { description }\end{array}$ & $\begin{array}{l}\text { Sample } \\
\text { collection } \\
\text { date }\end{array}$ & $\begin{array}{c}\text { Site } \\
\text { description }\end{array}$ & $\begin{array}{c}\text { Fluoranthene, } \\
\mu \mathrm{g} / \mathrm{L}\end{array}$ & $\begin{array}{c}\text { Fluoxetine, } \\
\mu \mathrm{g} / \mathrm{L}\end{array}$ \\
\hline Replicate leachate & Biosolids & $\begin{array}{l}\text { Archive of fresh, } \\
\text { dried (composite) }\end{array}$ & $\begin{array}{l}\text { 8/30/2005 leach of } \\
\text { 9/22/2004 biosolids }\end{array}$ & MWRD WWTP & $<50$ & NA \\
\hline Leachate & Biosolids & $\begin{array}{l}\text { Fresh, dried } \\
\text { (composite) }\end{array}$ & $\begin{array}{l}\text { 8/30/2005 leach of } \\
\text { January } 2005 \text { biosolids }\end{array}$ & MWRD WWTP & $<50$ & NA \\
\hline Replicate leachate & Biosolids & $\begin{array}{l}\text { Fresh, dried } \\
\text { (composite) }\end{array}$ & $\begin{array}{l}\text { 8/30/2005 leach of } \\
\text { January } 2005 \text { biosolids }\end{array}$ & MWRD WWTP & $<50$ & NA \\
\hline Leachate & Biosolids & $\begin{array}{l}\text { Fresh, moist } \\
\text { (composite) }\end{array}$ & $\begin{array}{l}\text { 8/30/2005 leach of } \\
8 / 23 / 2005 \text { biosolids }\end{array}$ & MWRD WWTP & $<50$ & NA \\
\hline Replicate leachate & Biosolids & $\begin{array}{l}\text { Fresh, dried } \\
\text { (composite) }\end{array}$ & $\begin{array}{c}12 / 19 / 2005 \text { leach of } \\
\text { November } 2005 \text { biosolids }\end{array}$ & MWRD WWTP & NA & $<0.016$ \\
\hline Leachate & Cow manure & Fresh field, dried & $\begin{array}{l}\text { 8/30/2005 leach of } \\
5 / 31 / 2005 \text { field sample }\end{array}$ & $\begin{array}{l}\text { South-2 (Cattle, } \\
\text { no farming, no biosolids) }\end{array}$ & $<50$ & NA \\
\hline Groundwater & Alluvial aquifer & DTX1 at $20 \mathrm{ft}$ & $7 / 5 / 2005$ & MWRD North Property & $<0.5$ & NA \\
\hline Groundwater & Alluvial aquifer & DTX2 at $14 \mathrm{ft}$ & $7 / 5 / 2005$ & MWRD North Property & $<0.5$ & NA \\
\hline Groundwater & Alluvial aquifer & D6 at $19 \mathrm{ft}$ & $7 / 6 / 2005$ & MWRD Central Property & $<0.5$ & NA \\
\hline \multicolumn{2}{|c|}{ Replicate groundwater sample } & D6 at $19 \mathrm{ft}$ & $7 / 6 / 2005$ & MWRD Central Property & $<0.5$ & NA \\
\hline Groundwater & Alluvial aquifer & D17 at $16 \mathrm{ft}$ & $7 / 6 / 2005$ & MWRD Central Property & $<0.5$ & NA \\
\hline Groundwater & Alluvial aquifer & $\mathrm{D} 25$ at $18 \mathrm{ft}$ & $7 / 5 / 2005$ & MWRD Central Property & $<0.5$ & NA \\
\hline \multicolumn{2}{|c|}{ Leachate equipment blank } & OBW & $8 / 30 / 2005$ & USGS laboratory & $<50$ & NA \\
\hline \multicolumn{2}{|c|}{ Leachate equipment blank } & OBW & $12 / 19 / 2005$ & USGS laboratory & NA & $<0.016$ \\
\hline
\end{tabular}


Appendix 4. Analytical data for leachate and groundwater samples associated with the biosolids-application area near Deer Trail, Colorado, 2005-Continued

[All leachate and groundwater chemical-concentration data are from filtered samples; associated data for matrix-spike recoveries are listed in appendix 5; sampling locations near Deer Trail are shown in figure 2; information for groundwater-sampling sites is provided in appendix 6; shaded analytes constitute a preliminary biosolids signature (summarized in table 3); MWRD properties are located near Deer Trail, Colorado, and are shown in figure 2; g, grams; L, liters; $\mu \mathrm{g} / \mathrm{L}$, micrograms per liter; $\%$, percent; $\mu \mathrm{S} / \mathrm{cm}$, microsiemens per centimeter at 25 degrees Celsius; $\mathrm{mg} / \mathrm{L}$, milligrams per liter; fresh, material obtained directly from wastewater treatment plant and processed inside laboratory; dried, material dewatered inside laboratory under forced-air conditions then ground to less than 150 micrometers prior to chemical analysis; MWRD, Metro Wastewater Reclamation District; WWTP, wastewater treatment plant in Denver, Colorado; $\mathrm{ft}$, feet below land surface; <, less than; NA, not analyzed; E, estimated by laboratory; $\mathrm{n}$, less than the minimum reporting level; field aged, material obtained from surface of farm field near Deer Trail, Colorado, about 8 months after application; fresh field, material obtained from surface of farm field near Deer Trail, Colorado, less than one day after deposited; OBW, organic-free blank water (certified); USGS, U.S. Geological Survey]

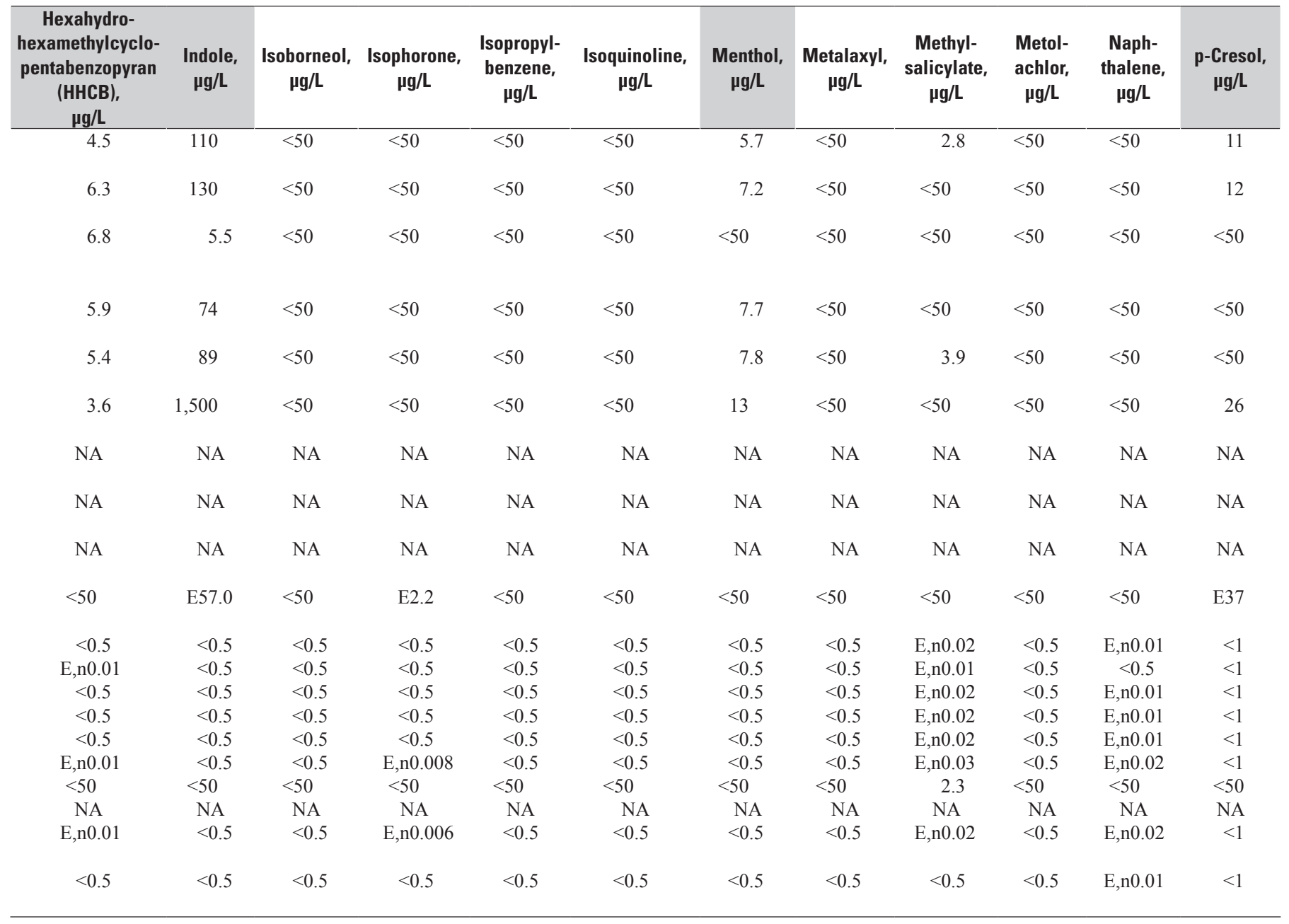


Appendix 4. Analytical data for leachate and groundwater samples associated with the biosolids-application area near Deer Trail, Colorado, 2005-Continued

[All leachate and groundwater chemical-concentration data are from filtered samples; associated data for matrix-spike recoveries are listed in appendix 5; sampling locations near Deer Trail are shown in figure 2; information for groundwater-sampling sites is provided in appendix 6; shaded analytes constitute a preliminary biosolids signature (summarized in table 3); MWRD properties are located near Deer Trail, Colorado, and are shown in figure 2; g, grams; L, liters; $\mu \mathrm{g} / \mathrm{L}$, micrograms per liter; $\%$, percent; $\mu \mathrm{S} / \mathrm{cm}$, microsiemens per centimeter at 25 degrees Celsius; $\mathrm{mg} / \mathrm{L}$, milligrams per liter; fresh, material obtained directly from wastewater treatment plant and processed inside laboratory; dried, material dewatered inside laboratory under forced-air conditions then ground to less than 150 micrometers prior to chemical analysis; MWRD, Metro Wastewater Reclamation District; WWTP, wastewater treatment plant in Denver, Colorado; $\mathrm{ft}$, feet below land surface; <, less than; NA, not analyzed; E, estimated by laboratory; n, less than the minimum reporting level; field aged, material obtained from surface of farm field near Deer Trail, Colorado, about 8 months after application; fresh field, material obtained from surface of farm field near Deer Trail, Colorado, less than one day after deposited; OBW, organic-free blank water (certified); USGS, U.S. Geological Survey]

\begin{tabular}{|c|c|c|c|c|c|c|c|}
\hline $\begin{array}{l}\text { Sample } \\
\text { type }\end{array}$ & $\begin{array}{l}\text { Source } \\
\text { material }\end{array}$ & $\begin{array}{c}\text { Source- } \\
\text { material or } \\
\text { sample-depth } \\
\text { description }\end{array}$ & $\begin{array}{l}\text { Sample } \\
\text { collection } \\
\text { date }\end{array}$ & $\begin{array}{c}\text { Site } \\
\text { description }\end{array}$ & $\begin{array}{c}\text { Phenan- } \\
\text { threne, } \\
\mu g / L\end{array}$ & $\begin{array}{c}\text { Phenol, } \\
\mu \mathrm{g} / \mathrm{L}\end{array}$ & $\begin{array}{c}\text { Prometon, } \\
\mu \mathrm{g} / \mathrm{L}\end{array}$ \\
\hline Leachate & Biosolids & $\begin{array}{l}\text { Archive of fresh, } \\
\text { dried (composite) }\end{array}$ & $\begin{array}{l}\text { 8/30/2005 leach of } \\
9 / 22 / 2004 \text { biosolids }\end{array}$ & MWRD WWTP & $<50$ & 930 & $<50$ \\
\hline Replicate leachate & Biosolids & $\begin{array}{l}\text { Archive of fresh, } \\
\text { dried (composite) }\end{array}$ & $\begin{array}{l}\text { 8/30/2005 leach of } \\
\text { 9/22/2004 biosolids }\end{array}$ & MWRD WWTP & $<50$ & 1,200 & $<50$ \\
\hline Leachate & Biosolids & Field aged & $\begin{array}{l}\text { 8/30/2005 leached of } \\
5 / 31 / 2005 \text { field sample }\end{array}$ & $\begin{array}{l}\text { DC300; biosolids applied } \\
\text { between late September } \\
\text { and early October } 2004\end{array}$ & $<50$ & $<50$ & $<50$ \\
\hline Leachate & Biosolids & $\begin{array}{l}\text { Fresh, dried } \\
\text { (composite) }\end{array}$ & $\begin{array}{l}\text { 8/30/2005 leach of } \\
\text { January } 2005 \text { biosolids }\end{array}$ & MWRD WWTP & $<50$ & 410 & $<50$ \\
\hline Replicate leachate & Biosolids & $\begin{array}{l}\text { Fresh, dried } \\
\text { (composite) }\end{array}$ & $\begin{array}{l}\text { 8/30/2005 leach of } \\
\text { January } 2005 \text { biosolids }\end{array}$ & MWRD WWTP & $<50$ & 400 & $<50$ \\
\hline Leachate & Biosolids & $\begin{array}{l}\text { Fresh, moist } \\
\text { (composite) }\end{array}$ & $\begin{array}{l}\text { 8/30/2005 leach of } \\
8 / 23 / 2005 \text { biosolids }\end{array}$ & MWRD WWTP & $<50$ & 15,000 & $<50$ \\
\hline Replicate leachate & Biosolids & $\begin{array}{l}\text { Fresh, dried } \\
\text { (composite) }\end{array}$ & $\begin{array}{c}12 / 19 / 2005 \text { leach of } \\
\text { November } 2005 \text { biosolids }\end{array}$ & MWRD WWTP & NA & NA & NA \\
\hline Leachate & Cow manure & Fresh field, dried & $\begin{array}{l}\text { 8/30/2005 leach of } \\
5 / 31 / 2005 \text { field sample }\end{array}$ & $\begin{array}{c}\text { South-2 (Cattle, } \\
\text { no farming, no biosolids) }\end{array}$ & $<50$ & E6.7 & $<50$ \\
\hline Groundwater & Alluvial aquifer & DTX1 at $20 \mathrm{ft}$ & $7 / 5 / 2005$ & MWRD North Property & $<0.5$ & $<0.5$ & $<0.5$ \\
\hline Groundwater & Alluvial aquifer & DTX2 at $14 \mathrm{ft}$ & $7 / 5 / 2005$ & MWRD North Property & $<0.5$ & $<0.5$ & $<0.5$ \\
\hline Groundwater & Alluvial aquifer & D6 at $19 \mathrm{ft}$ & $7 / 6 / 2005$ & MWRD Central Property & E,n0.005 & $<0.5$ & $<0.5$ \\
\hline \multicolumn{2}{|c|}{ Replicate groundwater sample } & D6 at $19 \mathrm{ft}$ & $7 / 6 / 2005$ & MWRD Central Property & E,n0.005 & $<0.5$ & $<0.5$ \\
\hline Groundwater & Alluvial aquifer & D17 at $16 \mathrm{ft}$ & $7 / 6 / 2005$ & MWRD Central Property & E,n0.004 & $<0.5$ & $<0.5$ \\
\hline Groundwater & Alluvial aquifer & $\mathrm{D} 25$ at $18 \mathrm{ft}$ & $7 / 5 / 2005$ & MWRD Central Property & $<0.5$ & E,n0.1 & $<0.5$ \\
\hline \multicolumn{2}{|c|}{ Leachate equipment blank } & OBW & $8 / 30 / 2005$ & USGS laboratory & $<50$ & $<50$ & $<50$ \\
\hline \multicolumn{2}{|c|}{ Leachate equipment blank } & OBW & $12 / 19 / 2005$ & USGS laboratory & NA & NA & NA \\
\hline
\end{tabular}


Appendix 4. Analytical data for leachate and groundwater samples associated with the biosolids-application area near Deer Trail, Colorado, 2005-Continued

[All leachate and groundwater chemical-concentration data are from filtered samples; associated data for matrix-spike recoveries are listed in appendix 5; sampling locations near Deer Trail are shown in figure 2; information for groundwater-sampling sites is provided in appendix 6; shaded analytes constitute a preliminary biosolids signature (summarized in table 3); MWRD properties are located near Deer Trail, Colorado, and are shown in figure 2; g, grams; L, liters; $\mu \mathrm{g} / \mathrm{L}$, micrograms per liter; \%, percent; $\mu \mathrm{S} / \mathrm{cm}$, microsiemens per centimeter at 25 degrees Celsius; $\mathrm{mg} / \mathrm{L}$, milligrams per liter; fresh, material obtained directly from wastewater treatment plant and processed inside laboratory; dried, material dewatered inside laboratory under forced-air conditions then ground to less than 150 micrometers prior to chemical analysis; MWRD, Metro Wastewater Reclamation District; WWTP, wastewater treatment plant in Denver, Colorado; $\mathrm{ft}$, feet below land surface; <, less than; NA, not analyzed; E, estimated by laboratory; $\mathrm{n}$, less than the minimum reporting level; field aged, material obtained from surface of farm field near Deer Trail, Colorado, about 8 months after application; fresh field, material obtained from surface of farm field near Deer Trail, Colorado, less than one day after deposited; OBW, organic-free blank water (certified); USGS, U.S. Geological Survey]

\begin{tabular}{|c|c|c|c|c|c|c|c|c|c|c|}
\hline $\begin{array}{c}\text { Pyrene, } \\
\mu \mathrm{g} / \mathrm{L}\end{array}$ & $\begin{array}{c}\text { Ranit- } \\
\text { idine, } \\
\mu \mathrm{g} / \mathrm{L}\end{array}$ & $\begin{array}{c}\text { Salbutamol } \\
\text { (albuterol), } \\
\mu \mathrm{g} / \mathrm{L}\end{array}$ & $\begin{array}{c}\text { Sulfa- } \\
\text { methoxazole, } \\
\mu \mathrm{g} / \mathrm{L}\end{array}$ & $\begin{array}{l}\text { Tetrachloro- } \\
\text { ethene (PERC or } \\
\text { PCE), } \mu \mathrm{g} / \mathrm{L}\end{array}$ & $\begin{array}{c}\text { Thiaben- } \\
\text { dazole, } \\
\mu \mathrm{g} / \mathrm{L}\end{array}$ & $\begin{array}{c}\text { Tribromo- } \\
\text { methane } \\
\text { (bromoform), } \\
\mu \mathrm{g} / \mathrm{L}\end{array}$ & $\begin{array}{c}\text { Tri- } \\
\text { butyl- } \\
\text { phosphate, } \\
\mu \mathrm{g} / \mathrm{L}\end{array}$ & $\begin{array}{l}\text { Tri- } \\
\text { closan, } \\
\mu \mathrm{g} / \mathrm{L}\end{array}$ & $\begin{array}{l}\text { Triethyl } \\
\text { citrate, } \\
\mu \mathrm{g} / \mathrm{L}\end{array}$ & $\begin{array}{c}\text { Tri- } \\
\text { methoprim, } \\
\mu \mathrm{g} / \mathrm{L}\end{array}$ \\
\hline$<50$ & NA & NA & NA & $<50$ & NA & $<50$ & 3.7 & $<50$ & $<50$ & NA \\
\hline$<50$ & NA & NA & NA & $<50$ & NA & $<50$ & 4.1 & 3.4 & $<50$ & NA \\
\hline$<50$ & NA & NA & NA & $<50$ & NA & $<50$ & $<50$ & $<50$ & $<50$ & NA \\
\hline$<50$ & NA & NA & NA & $<50$ & NA & $<50$ & $<50$ & 5 & $<50$ & NA \\
\hline$<50$ & NA & NA & NA & $<50$ & NA & $<50$ & $<50$ & 4 & $<50$ & NA \\
\hline$<50$ & NA & NA & NA & $<50$ & NA & $<50$ & 3.9 & 3.4 & $<50$ & NA \\
\hline NA & $<0.025$ & $<0.014$ & $<0.024$ & NA & $<0.025$ & NA & NA & NA & NA & $<0.020$ \\
\hline$<50$ & NA & NA & NA & $<50$ & NA & $<50$ & $<50$ & $<50$ & $<50$ & NA \\
\hline$<0.5$ & NA & NA & NA & $<0.5$ & NA & $<0.5$ & $<0.5$ & $<1$ & $<0.5$ & NA \\
\hline$<0.5$ & NA & NA & NA & $<0.5$ & NA & $<0.5$ & $<0.5$ & $<1$ & $<0.5$ & NA \\
\hline$<0.5$ & NA & NA & NA & $<0.5$ & NA & $<0.5$ & $<0.5$ & $<1$ & $<0.5$ & NA \\
\hline$<0.5$ & NA & NA & NA & $<0.5$ & NA & NA & $<0.5$ & $<1$ & $<0.5$ & NA \\
\hline$<0.5$ & NA & NA & NA & $<0.5$ & NA & $<0.5$ & $<0.5$ & $<1$ & $<0.5$ & NA \\
\hline$<0.5$ & NA & NA & NA & $<0.5$ & NA & $<0.5$ & $<0.5$ & $<1$ & $<0.5$ & NA \\
\hline$<50$ & NA & NA & NA & $<50$ & NA & $<50$ & $<50$ & $<50$ & $<50$ & NA \\
\hline NA & $<0.025$ & $<0.014$ & $<0.024$ & NA & $<0.025$ & NA & NA & NA & NA & $<0.020$ \\
\hline
\end{tabular}


Appendix 4. Analytical data for leachate and groundwater samples associated with the biosolids-application area near Deer Trail, Colorado, 2005-Continued

[All leachate and groundwater chemical-concentration data are from filtered samples; associated data for matrix-spike recoveries are listed in appendix 5; sampling locations near Deer Trail are shown in figure 2; information for groundwater-sampling sites is provided in appendix 6; shaded analytes constitute a preliminary biosolids signature (summarized in table 3); MWRD properties are located near Deer Trail, Colorado, and are shown in figure 2; g, grams; L, liters; $\mu \mathrm{g} / \mathrm{L}$, micrograms per liter; $\%$, percent; $\mu \mathrm{S} / \mathrm{cm}$, microsiemens per centimeter at 25 degrees Celsius; $\mathrm{mg} / \mathrm{L}$, milligrams per liter; fresh, material obtained directly from wastewater treatment plant and processed inside laboratory; dried, material dewatered inside laboratory under forced-air conditions then ground to less than 150 micrometers prior to chemical analysis; MWRD, Metro Wastewater Reclamation District; WWTP, wastewater treatment plant in Denver, Colorado; $\mathrm{ft}$, feet below land surface; <, less than; NA, not analyzed; E, estimated by laboratory; $\mathrm{n}$, less than the minimum reporting level; field aged, material obtained from surface of farm field near Deer Trail, Colorado, about 8 months after application; fresh field, material obtained from surface of farm field near Deer Trail, Colorado, less than one day after deposited; OBW, organic-free blank water (certified); USGS, U.S. Geological Survey]

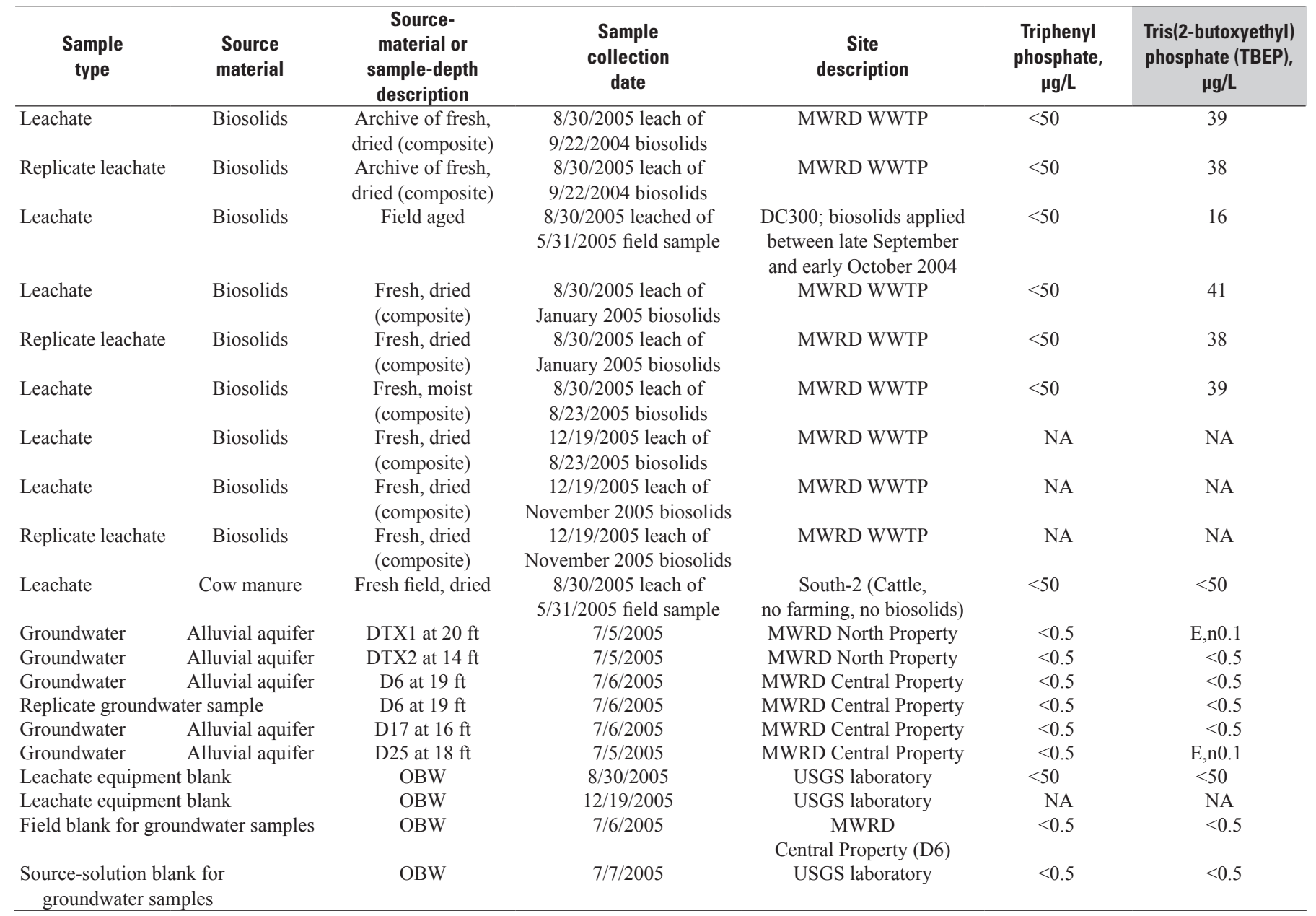


Appendix 4. Analytical data for leachate and groundwater samples associated with the biosolids-application area near Deer Trail, Colorado, 2005-Continued

[All leachate and groundwater chemical-concentration data are from filtered samples; associated data for matrix-spike recoveries are listed in appendix 5; sampling locations near Deer Trail are shown in figure 2; information for groundwater-sampling sites is provided in appendix 6; shaded analytes constitute a preliminary biosolids signature (summarized in table 3); MWRD properties are located near Deer Trail, Colorado, and are shown in figure 2; g, grams; L, liters; $\mu \mathrm{g} / \mathrm{L}$, micrograms per liter; $\%$, percent; $\mu \mathrm{S} / \mathrm{cm}$, microsiemens per centimeter at 25 degrees Celsius; $\mathrm{mg} / \mathrm{L}$, milligrams per liter; fresh, material obtained directly from wastewater treatment plant and processed inside laboratory; dried, material dewatered inside laboratory under forced-air conditions then ground to less than 150 micrometers prior to chemical analysis; MWRD, Metro Wastewater Reclamation District; WWTP, wastewater treatment plant in Denver, Colorado; $\mathrm{ft}$, feet below land surface; <, less than; NA, not analyzed; E, estimated by laboratory; $\mathrm{n}$, less than the minimum reporting level; field aged, material obtained from surface of farm field near Deer Trail, Colorado, about 8 months after application; fresh field, material obtained from surface of farm field near Deer Trail, Colorado, less than one day after deposited; OBW, organic-free blank water (certified); USGS, U.S. Geological Survey]

\begin{tabular}{|c|c|c|c|c|c|c|c|}
\hline $\begin{array}{c}\text { Tris(2-chloroethyl) } \\
\text { phosphate, } \\
\mu \mathrm{g} / \mathrm{L}\end{array}$ & $\begin{array}{c}\text { Tris } \\
\text { (dichloroisopropyl) } \\
\text { phosphate, } \\
\mu \mathrm{g} / \mathrm{L}\end{array}$ & $\begin{array}{c}\text { Warfarin, } \\
\mu \mathrm{g} / \mathrm{L}\end{array}$ & $\begin{array}{c}\text { Caffeine-13C } \\
\text { (surrogate), } \\
\%\end{array}$ & $\begin{array}{c}\text { Carbamazepine-d10 } \\
\text { (surrogate), } \\
\%\end{array}$ & $\begin{array}{c}\text { Decafluoro- } \\
\text { biphenyl } \\
\text { (surrogate), } \\
\%\end{array}$ & $\begin{array}{c}\text { Ethyl } \\
\text { nicotinate-d4 } \\
\text { (surrogate), } \\
\%\end{array}$ & $\begin{array}{c}\text { Fluoranthene-d10 } \\
\text { (surrogate), } \\
\%\end{array}$ \\
\hline$<50$ & $<50$ & NA & 67.1 & NA & 49.2 & NA & 66.9 \\
\hline$<50$ & $<50$ & NA & 79.3 & NA & 49.0 & NA & 71.5 \\
\hline$<50$ & $<50$ & NA & 52.7 & NA & 46.5 & NA & 60.0 \\
\hline$<50$ & $<50$ & NA & 87.4 & NA & 45.2 & NA & 66.2 \\
\hline$<50$ & $<50$ & NA & 87.5 & NA & 46.5 & NA & 61.0 \\
\hline$<50$ & $<50$ & NA & 81.5 & NA & 51.5 & NA & 72.4 \\
\hline NA & NA & $<0.019$ & NA & E1.1 & NA & E15 & NA \\
\hline$<50$ & $<50$ & NA & NA & NA & NA & NA & NA \\
\hline$<0.5$ & $<0.5$ & NA & 91.5 & NA & 90.7 & NA & 83.6 \\
\hline$<0.5$ & $<0.5$ & NA & 84.8 & NA & 96.1 & NA & 81.8 \\
\hline$<0.5$ & $<0.5$ & NA & 84.1 & NA & 72.3 & NA & 81.1 \\
\hline$<0.5$ & $<0.5$ & NA & 91.6 & NA & 71.2 & NA & 86.1 \\
\hline$<0.5$ & $<0.5$ & NA & 84.3 & NA & 73.9 & NA & 77.0 \\
\hline$<0.5$ & $<0.5$ & NA & 93.4 & NA & 94.0 & NA & 89.2 \\
\hline$<50$ & $<50$ & NA & 75.9 & NA & 51.2 & NA & 73.3 \\
\hline NA & NA & $<0.019$ & NA & 35.2 & NA & 23.9 & NA \\
\hline$<0.5$ & $<0.5$ & NA & 93.7 & NA & 66.8 & NA & 84.9 \\
\hline
\end{tabular}


Appendix 5. Matrix-spike recoveries for leachate and groundwater samples associated with the Metro Wastewater Reclamation District biosolidsapplication area near Deer Trail, Colorado, 2005, and analyzed by the U.S. Geological Survey National Water Quality Laboratory:

[Matrix-spike recoveries are calculated from analysis of a replicate filtered sample that was spiked with a known concentration of target analytes to evaluate bias in the analytical method for that sample matrix. Increased bias is indicated for values where concentrations in the unspiked sample relative to the fortified amount were 100 to 150 percent (italicized values), 150 to 300 percent (bold values), or greater than 300 percent (NR). Where concentrations in the unspiked sample were censored at less than the reporting level by the laboratory, the unspiked concentration was assumed to be zero for this analysis; recovery for that analyte could be less than shown. Gray shaded values indicate that the reported estimated spike concentration and the censored concentration in the unspiked sample both were less than the minimum reporting level. --, not analyzed for one or both samples; NC, not calculated because concentrations of both spiked and unspiked samples were censored at the minimum reporting level and were censored; NR, not reported because unspiked concentrations exceeded 300 percent of fortified amount, which produced substantially skewed recoveries]

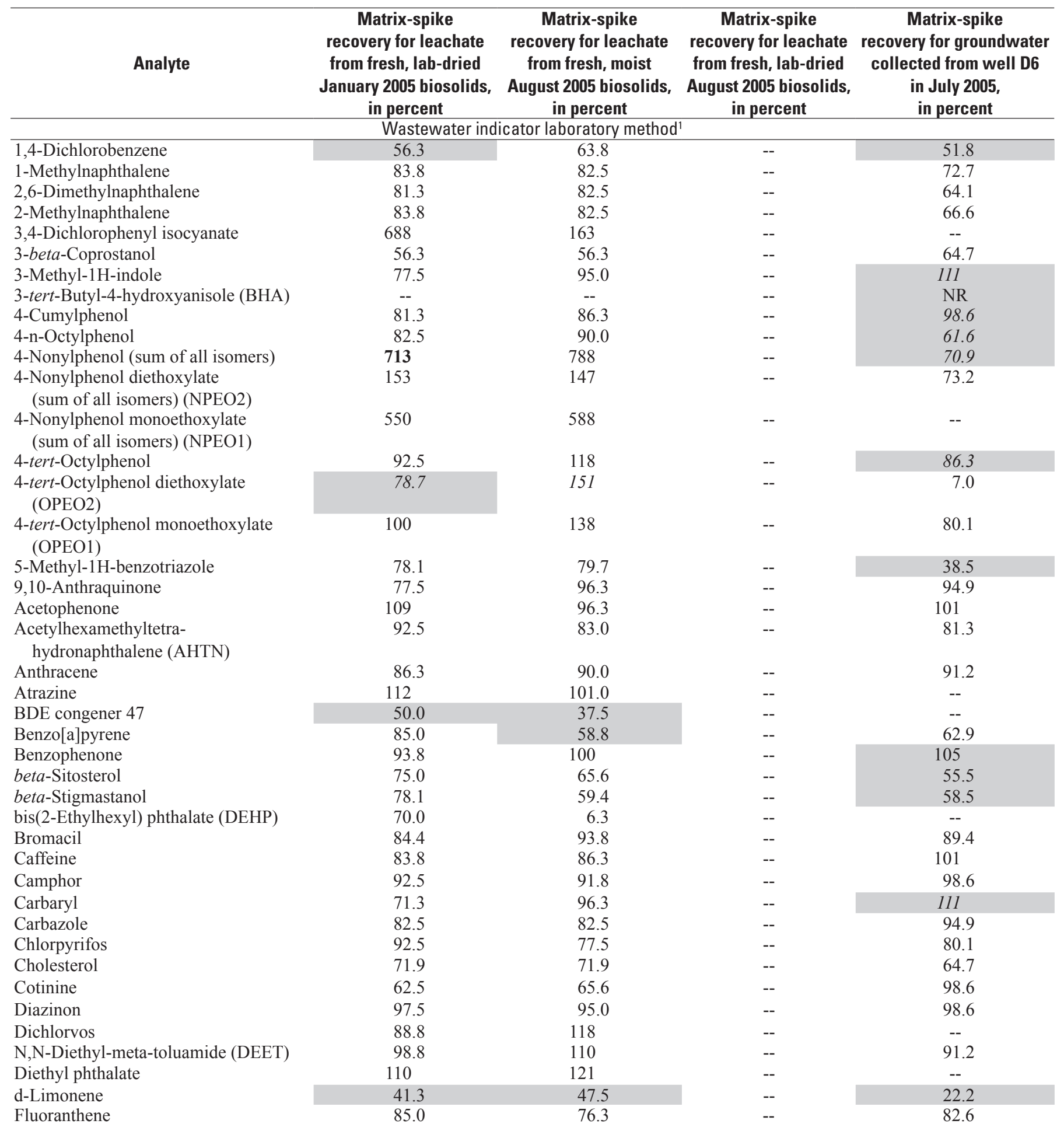


Appendix 5. Matrix-spike recoveries for leachate and groundwater samples associated with the Metro Wastewater Reclamation District biosolidsapplication area near Deer Trail, Colorado, 2005, and analyzed by the U.S. Geological Survey National Water Quality Laboratory. - Continued

[Matrix-spike recoveries are calculated from analysis of a replicate filtered sample that was spiked with a known concentration of target analytes to evaluate bias in the analytical method for that sample matrix. Increased bias is indicated for values where concentrations in the unspiked sample relative to the fortified amount were 100 to 150 percent (italicized values), 150 to 300 percent (bold values), or greater than 300 percent (NR). Where concentrations in the unspiked sample were censored at less than the reporting level by the laboratory, the unspiked concentration was assumed to be zero for this analysis; recovery for that analyte could be less than shown. Gray shaded values indicate that the reported estimated spike concentration and the censored concentration in the unspiked sample both were less than the minimum reporting level. --, not analyzed for one or both samples; NC, not calculated because concentrations of both spiked and unspiked samples were censored at the minimum reporting level and were censored; NR, not reported because unspiked concentrations exceeded 300 percent of fortified amount, which produced substantially skewed recoveries]

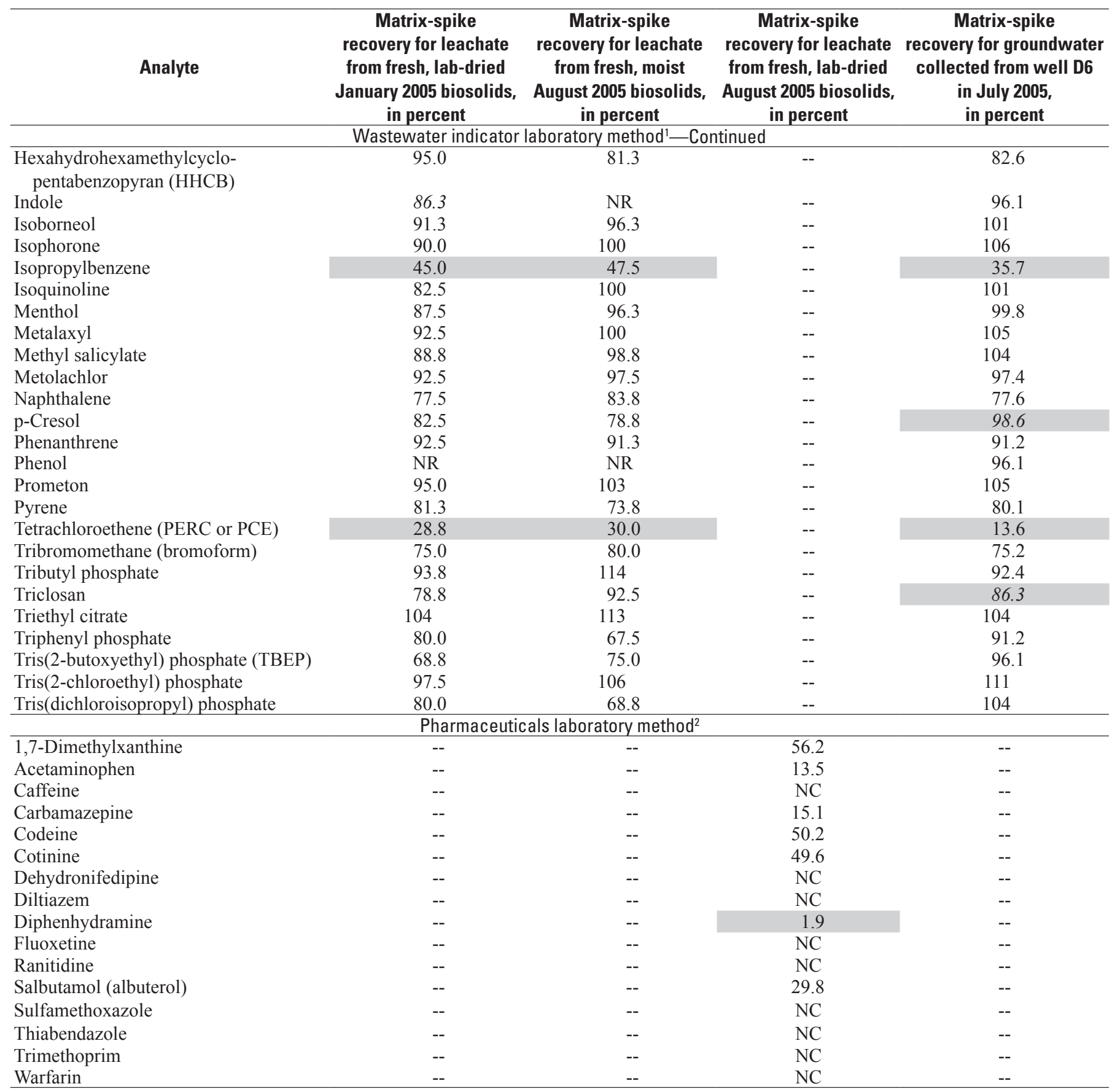

${ }^{1}$ Wastewater-indicator-method analytes were analyzed by capillary-column gas chromatography/mass spectrometry for leachate samples (continuous liquidliquid extraction; Zaugg, Smith, and Schroeder, 2006) and groundwater samples (polystyrene-divinylbenzene solid-phase extraction; Zaugg and others, 2002).

${ }^{2}$ Pharmaceutical-method analytes in leachate and groundwater samples were analyzed by solid phase, hydrophilic-lipophilic-balance extraction and highperformance liquid chromatographydescribed by Cahill and others (2004) and further validated in Furlong and others (2008). 
Appendix 6. Selected information for U.S. Geological Survey monitoring wells near Deer Trail, Colorado, 2004-2010.

[Wells shown in bold routinely were sampled for chemistry; all wells have 2-inch-diameter casing; latitude and longitude are in the format degrees minutes seconds referenced to North American Datum of 1983; Alt., altitude in feet above North American Vertical Datum of 1988; stickup, the length of well casing above ground (fluctuates because land surface is uneven and changes height over time from local erosion and deposition), and measuring point is at the top of the stickup; bmp, below measuring point; sump, the nonperforated closed casing below the screen; HUC, Hydrologic Unit Code (Seaber and others, 1987); NWIS, U.S. Geological Survey National Water Information System database; ID, identification number; Metro, Metro Wastewater Reclamation District; L, alluvial; P, private owner; R, bedrock; SR, shallow and likely bedrock; S, shallow well; SL, shallow and likely alluvial; K, owned by Metro Wastewater Reclamation District until 1995 then transferred to a private owner]

\begin{tabular}{|c|c|c|c|c|c|c|c|c|c|c|c|c|c|c|c|c|c|c|}
\hline Well & Latitude & Longitude & $\begin{array}{c}\text { Alt. of } \\
\text { stickup } \\
\text { (feet) }\end{array}$ & $\begin{array}{c}\text { Alt. of } \\
\text { land } \\
\text { surface } \\
\text { (feet) }\end{array}$ & $\begin{array}{c}\text { Property } \\
\text { owner }\end{array}$ & County & $\begin{array}{l}\text { Drill } \\
\text { date }\end{array}$ & $\begin{array}{l}\text { Measured } \\
\text { stickup }\end{array}$ & $\begin{array}{c}\text { Total } \\
\text { depth } \\
\text { (feet bmp) }\end{array}$ & $\begin{array}{c}\text { Screen } \\
\text { top } \\
\text { (feet bmp) }\end{array}$ & $\begin{array}{c}\text { Screen } \\
\text { bottom } \\
\text { (feet bmp) }\end{array}$ & $\begin{array}{l}\text { Screen- } \\
\text { slot size } \\
\text { (inch) }\end{array}$ & $\begin{array}{l}\text { Screen } \\
\text { length } \\
\text { (feet) }\end{array}$ & $\begin{array}{l}\text { Sump } \\
\text { length } \\
\text { (feet) }\end{array}$ & $\begin{array}{l}\text { Aquifer } \\
\text { type }\end{array}$ & $\begin{array}{l}\text { Topo- } \\
\text { graphic } \\
\text { setting }\end{array}$ & HUC & $\begin{array}{c}\text { NWIS } \\
\text { station ID }\end{array}$ \\
\hline DTX1 & 394333 & 1035251 & 4,909 & 4,906 & Metro & Arapahoe & 2/16/1999 & 2.56 & 25.50 & 20.59 & 22.19 & 0.010 & 1.60 & 3.31 & $\mathrm{~L}$ & Flood plain & 10190012 & 394333103525100 \\
\hline DTX2 & 394149 & 1035138 & 4,903 & 4,900 & Metro & Arapahoe & 2/16/1999 & 3.23 & 20.50 & 15.59 & 17.19 & 0.010 & 1.60 & 3.31 & $\mathrm{~L}$ & Flood plain & 10190012 & 394148103513300 \\
\hline DTX3 & 393024 & 1034328 & 5,195 & 5,192 & Metro & Elbert & 2/12/1999 & 3.11 & 18.71 & 13.80 & 15.40 & 0.010 & 1.60 & 3.31 & $\mathrm{~L}$ & Flood plain & 10190013 & 393024103432800 \\
\hline DTX4 & 393358 & 1034342 & 4,957 & 4,954 & Metro & Elbert & 2/10/1999 & 2.70 & 16.72 & 11.81 & 13.41 & 0.010 & 1.60 & 3.31 & $\mathrm{~L}$ & Flood plain & 10190013 & 393358103434200 \\
\hline DTX5 & 393358 & 1034548 & 4,975 & 4,973 & Metro & Elbert & 2/10/1999 & 2.30 & 20.90 & 16.09 & 17.69 & 0.010 & 1.60 & 3.21 & $\mathrm{~L}$ & Terrace & 10190013 & 393358103454800 \\
\hline DTX6 & 393358 & 1034648 & 4,970 & 4,968 & Metro & Elbert & 2/9/1999 & 22.36 & 39 & 34 & 36 & 0.010 & 1.60 & 3.31 & $\mathrm{~L}$ & Terrace & 10190013 & 393358103464800 \\
\hline DTX7 & 394054 & 1035646 & 5,076 & 5,073 & $\mathrm{P}$ & Arapahoe & 2/18/1999 & 2.77 & 16.10 & 11.19 & 12.79 & 0.010 & 1.60 & 3.31 & $\mathrm{~L}$ & Flood plain & 10190011 & 394054103564600 \\
\hline DTX8A $^{4}$ & 394054 & 1035645 & 5,076 & 5,074 & $\mathrm{P}$ & Arapahoe & 3/2/1999 & 2.46 & 77.52 & 67.56 & 71.83 & 0.010 & 4.27 & 5.69 & $\mathrm{R}$ & Flood plain & 10190011 & 394054103564501 \\
\hline DTX8B ${ }^{4}$ & 394054 & 1035645 & 5,076 & 5,074 & $\mathrm{P}$ & Arapahoe & 3/2/1999 & 2.49 & 177.48 & 167.52 & 171.79 & 0.010 & 4.27 & 5.69 & $\mathrm{R}$ & Flood plain & 10190011 & 394054103564502 \\
\hline DTX9 ${ }^{3}$ & 393902 & 1035540 & 5,121 & 5,119 & $\mathrm{P}$ & Arapahoe & 2/17/1999 & 2.46 & 30.15 & 22.72 & 24.32 & 0.010 & 1.60 & 5.83 & $\mathrm{~L}$ & Flood plain & 10190011 & 393902103554000 \\
\hline DTX10A $^{3,4}$ & 393902 & 1035540 & 5,122 & 5,120 & $\mathrm{P}$ & Arapahoe & 3/4/1999 & 2.03 & 61.97 & 52.01 & 56.28 & 0.010 & 4.27 & 5.69 & $\mathrm{R}$ & Flood plain & 10190011 & 393902103554001 \\
\hline DTX10B ${ }^{4}$ & 393902 & 1035540 & 5,122 & 5,120 & $\mathrm{P}$ & Arapahoe & 3/4/1999 & 2.11 & 121.73 & 111.77 & 116.04 & 0.010 & 4.27 & 5.69 & $\mathrm{R}$ & Flood plain & 10190011 & 393902103554002 \\
\hline DTX1133 & 393902 & 1035540 & 5,122 & 5,120 & $\mathrm{P}$ & Arapahoe & $1 / 19 / 2000$ & 2.24 & 32 & 28 & 30 & 0.020 & 1.85 & 2.35 & $\mathrm{~L}$ & Flood plain & 10190011 & 393902103554003 \\
\hline DTX12 & 393654 & 1035120 & 5,096 & 5,093 & Metro & Arapahoe & 9/1/2009 & 2.73 & 20.06 & 16.33 & 18.52 & 0.010 & 2.19 & 1.54 & $\mathrm{~L}$ & Flood plain & 10190013 & 393953103554002 \\
\hline D3 & 393721 & 1035431 & 5,191 & 5,188 & Metro & Arapahoe & 9/11/1993 & 2.83 & 46 & 36 & 46 & 0.010 & 10 & $<1$ & SR & Flood plain & 10190011 & 393723103535400 \\
\hline D4 & 393641 & 1035351 & 5,213 & 5,210 & Metro & Arapahoe & 9/10/1993 & 2.11 & 34 & 24 & 34 & 0.010 & 10 & $<1$ & SR & Flood plain & 10190011 & 393622103542900 \\
\hline D5 & 393619 & 1035155 & 5,198 & 5,195 & Metro & Arapahoe & 9/11/1993 & 3.45 & 30 & 20 & 30 & 0.010 & 10 & $<1$ & $\mathrm{~S}$ & Flood plain & 10190013 & 393619103515500 \\
\hline D6 & 393633 & 1035122 & 5,129 & 5,126 & Metro & Arapahoe & 9/12/1993 & 2.65 & 25 & 15 & 25 & 0.010 & 10 & 0.3 & $\mathrm{~L}$ & Flood plain & 10190013 & 393633103512300 \\
\hline D6A & 393633 & 1035122 & 5,129 & 5,126 & Metro & Arapahoe & 2/6/2002 & 2.42 & 32.96 & 28.42 & 30.71 & 0.010 & 2.29 & 2.25 & $\mathrm{~L}$ & Flood plain & 10190013 & 393633103512301 \\
\hline D7 & 393601 & 1035356 & 5,223 & 5,221 & Metro & Arapahoe & 9/10/1993 & 2.62 & 25 & 15 & 25 & 0.010 & 10 & $<1$ & SL & Flood plain & 10190011 & 393622103540900 \\
\hline D8 & 393637 & 1035422 & 5,189 & 5,186 & Metro & Arapahoe & 9/10/1993 & 2.79 & 20 & 10 & 20 & 0.010 & 10 & $<1$ & SL & Flood plain & 10190011 & 393637103542400 \\
\hline D10 & 393608 & 1035150 & 5,200 & 5,197 & Metro & Arapahoe & 9/11/1993 & 2.40 & 20 & 10 & 20 & 0.010 & 10 & $<1$ & $\mathrm{~S}$ & Stream channel & 10190013 & 393609103514600 \\
\hline D11a & 393345 & 1035423 & 5,377 & 5,374 & Metro & Elbert & 10/23/1997 & 2.46 & 143.03 & 112.65 & 122.65 & 0.010 & 10 & 20.38 & $\mathrm{R}$ & Hilltop & 10190011 & 393334103543600 \\
\hline D13 & 393442 & 1035438 & 5,235 & 5,234 & Metro & Arapahoe & 4/4/1994 & 1.81 & 16 & 6 & 16 & 0.010 & 10 & 0.3 & $\mathrm{~L}$ & Flood plain & 10190011 & 393439103543400 \\
\hline D14 & 393429 & 1035403 & 5,272 & 5,271 & Metro & Arapahoe & 4/4/1994 & 1.39 & 24 & 14 & 24 & 0.010 & 10 & $<1$ & $\mathrm{~S}$ & Flood plain & 10190011 & 393427103540000 \\
\hline D15 & 393359 & 1035454 & 5,247 & 5,245 & $\mathrm{~K}$ & Elbert & 4/7/1994 & 1.86 & 25 & 15 & 25 & 0.010 & 10 & $<1$ & SL & Flood plain & 10190011 & 393357103545200 \\
\hline D16 & 393306 & 1035456 & 5,279 & 5,277 & K & Elbert & 4/7/1994 & 1.88 & 25 & 15 & 25 & 0.010 & 10 & $<1$ & $\mathrm{~S}$ & Flood plain & 10190011 & 393307103545500 \\
\hline
\end{tabular}


Appendix 6. Selected information for U.S. Geological Survey monitoring wells near Deer Trail, Colorado, 2004-2010.—Continued

[Wells shown in bold routinely were sampled for chemistry; all wells have 2-inch-diameter casing; latitude and longitude are in the format degrees minutes seconds referenced to North American Datum of 1983; Alt., altitude in feet above North American Vertical Datum of 1988; stickup, the length of well casing above ground (fluctuates because land surface is uneven and changes height over time from local erosion and deposition), and measuring point is at the top of the stickup; bmp, below measuring point; sump, the nonperforated closed casing below the screen; HUC, Hydrologic Unit Code (Seaber and others, 1987); NWIS, U.S. Geological Survey National Water Information System database; ID, identification number; Metro, Metro Wastewater Reclamation District; L, alluvial; P, private owner; R, bedrock; SR, shallow and likely bedrock; S, shallow well; SL, shallow and likely alluvial; K, owned by Metro Wastewater Reclamation District until 1995 then transferred to a private owner]

\begin{tabular}{|c|c|c|c|c|c|c|c|c|c|c|c|c|c|c|c|c|c|c|}
\hline Well & Latitude & Longitude & $\begin{array}{c}\text { Alt. of } \\
\text { stickup } \\
\text { (feet) }\end{array}$ & $\begin{array}{l}\text { Alt. of } \\
\text { land } \\
\text { surface } \\
\text { (feet) }\end{array}$ & $\begin{array}{l}\text { Property } \\
\text { owner }\end{array}$ & County & $\begin{array}{l}\text { Drill } \\
\text { date }\end{array}$ & $\begin{array}{c}\text { Measured } \\
\text { stickup }\end{array}$ & $\begin{array}{c}\text { Total } \\
\text { depth } \\
\text { (feet bmp) }\end{array}$ & $\begin{array}{c}\text { Screen } \\
\text { top } \\
\text { (feet bmp) }\end{array}$ & $\begin{array}{c}\text { Screen } \\
\text { bottom } \\
\text { (feet bmp) }\end{array}$ & $\begin{array}{c}\text { Screen- } \\
\text { slot size } \\
\text { (inch) }\end{array}$ & $\begin{array}{c}\text { Screen } \\
\text { length } \\
\text { (feet) }\end{array}$ & $\begin{array}{c}\text { Sump } \\
\text { length } \\
\text { (feet) }\end{array}$ & $\begin{array}{l}\text { Aquifer } \\
\text { type }\end{array}$ & $\begin{array}{l}\text { Topo- } \\
\text { graphic } \\
\text { setting }\end{array}$ & HUC & $\begin{array}{c}\text { NWIS } \\
\text { station ID }\end{array}$ \\
\hline D17 & 393334 & 1035436 & 5,278 & 5,276 & Metro & Elbert & 4/5/1994 & 1.90 & 21 & 11 & 21 & 0.010 & 10 & 0.3 & $\mathrm{~L}$ & Flood plain & 10190011 & 393327103541200 \\
\hline D19 & 393317 & 1035418 & 5,304 & 5,303 & Metro & Elbert & 4/5/1994 & 1.69 & 30 & 20 & 30 & 0.010 & 10 & 0.3 & $\mathrm{R}$ & Upland draw & 10190011 & 393311103541800 \\
\hline D20 & 393246 & 1035442 & 5,282 & 5,280 & K & Elbert & 4/6/1994 & 2.27 & 22 & 12 & 22 & 0.010 & 10 & $<1$ & $\mathrm{~S}$ & Flood plain & 10190011 & 393247103543800 \\
\hline D21 & 393209 & 1035446 & 5,319 & 5,317 & K & Elbert & 4/5/1994 & 1.71 & 20 & 10 & 20 & 0.010 & 10 & $<1$ & $\mathrm{~S}$ & Flood plain & 10190011 & 393207103544800 \\
\hline D22 & 393308 & 1035200 & 5,158 & 5,154 & Metro & Elbert & 4/8/1994 & 3.58 & 41 & 31 & 41 & 0.010 & 10 & $<1$ & SR & Flood plain & 10190013 & 393307103515900 \\
\hline D23 & 393342 & 1035501 & 5,254 & 5,251 & $\mathrm{~K}$ & Elbert & $4 / 8 / 1994$ & 2.54 & 15 & 10 & 15 & 0.010 & 5 & $<1$ & $\mathrm{~L}$ & Flood plain & 10190011 & 393330103545300 \\
\hline D25 & 393702 & 1035442 & 5,167 & 5,165 & Metro & Arapahoe & $5 / 1 / 1995$ & 2.23 & 23 & 13 & 23 & 0.010 & 10 & 0.3 & $\mathrm{~L}$ & Flood plain & 10190011 & 393702103544100 \\
\hline D25A & 393702 & 1035442 & 5,167 & 5,165 & Metro & Arapahoe & $2 / 5 / 2002$ & 2.28 & 24.39 & 19.85 & 22.14 & 0.010 & 2.29 & 2.25 & $\mathrm{~L}$ & Flood plain & 10190011 & 393702103544102 \\
\hline D26 & 393639 & 1035330 & 5,233 & 5,231 & Metro & Arapahoe & $5 / 3 / 1995$ & 2.44 & 44 & 34 & 44 & 0.010 & 10 & $<1$ & SR & Flood plain & 10190011 & 393639103533000 \\
\hline D27 & 393621 & 1035409 & 5,207 & 5,204 & Metro & Arapahoe & $5 / 2 / 1995$ & 2.77 & 26 & 16 & 26 & 0.010 & 10 & $<1$ & $\mathrm{SL}$ & Flood plain & 10190011 & 393621103540900 \\
\hline D28 & 393545 & 1035340 & 5,239 & 5,237 & Metro & Arapahoe & $5 / 2 / 1995$ & 2.12 & 30 & 20 & 30 & 0.010 & 10 & $<1$ & SL & Stream channel & 10190011 & 393545103534000 \\
\hline D29 & 393641 & 1035248 & 5,371 & 5,369 & Metro & Arapahoe & 11/4/1997 & 2.38 & 183.19 & 147.81 & 157.81 & 0.010 & 10 & 25.38 & $\mathrm{R}$ & Hilltop & 10190013 & 393632103524300 \\
\hline D31 & 393656 & 1035138 & 5,120 & 5,118 & Metro & Arapahoe & $5 / 4 / 1995$ & 1.84 & 26 & 11 & 21 & 0.010 & 10 & 5 & $\mathrm{~S}$ & Flood plain & 10190013 & 393656103513900 \\
\hline D32 & 393609 & 1035126 & 5,189 & 5,187 & Metro & Arapahoe & $5 / 9 / 1995$ & 1.99 & 40 & 30 & 40 & 0.010 & 10 & $<1$ & SR & Stream channel & 10190013 & 393609103513900 \\
\hline D33 & 393556 & 1035153 & 5,229 & 5,227 & Metro & Arapahoe & $5 / 5 / 1995$ & 1.73 & 25 & 10 & 20 & 0.010 & 10 & 5 & $\mathrm{~S}$ & Flood plain & 10190013 & 393556103515300 \\
\hline
\end{tabular}

${ }^{1}$ Stickup measured at a specific date and time soon after well was installed, but this measurement is relative to land surface, which is not uniform or constant over time.

${ }^{2}$ DTX6 stickup went from 2.43 to 2.36 feet between mid-October 2002 and early November 2002 when well was vandalized.

${ }^{3}$ Well had continuous-recorder equipment to evaluate recharge.

${ }^{4}$ DTX8 and DTX10 are nested wells that consist of a single borehole that has two separate piezometers screened at two separate zones; the shallow zone is designated by "A" and the deep zone is designated by "B" after the well name. 
Appendix 7. Relative standard deviation for replicate groundwater samples collected near Deer Trail, Colorado, $2004-2010$.

[Relative standard deviation is defined as ((square root $\left.\left((\text { sample value }- \text { replicate value })^{2} / 2\right)\right) /(($ sample value + replicate value $\left.) / 2)\right) \times 100$ and therefore expressed as a percentage; for this analysis, all values that were less than the minimum reporting level were set equal to the minimum reporting level and estimated values were included; calculations done on unrounded data; $\mu \mathrm{S} / \mathrm{cm}$, microsiemens per centimeter; ${ }^{\circ} \mathrm{C}$, degrees Celsius; dissolved, from filtered sample; mg/L, milligrams per liter; $\mathrm{N}$, nitrogen; total, from unfiltered sample; $\mu \mathrm{g} / \mathrm{L}$, micrograms per liter; --, insufficient data to determine]

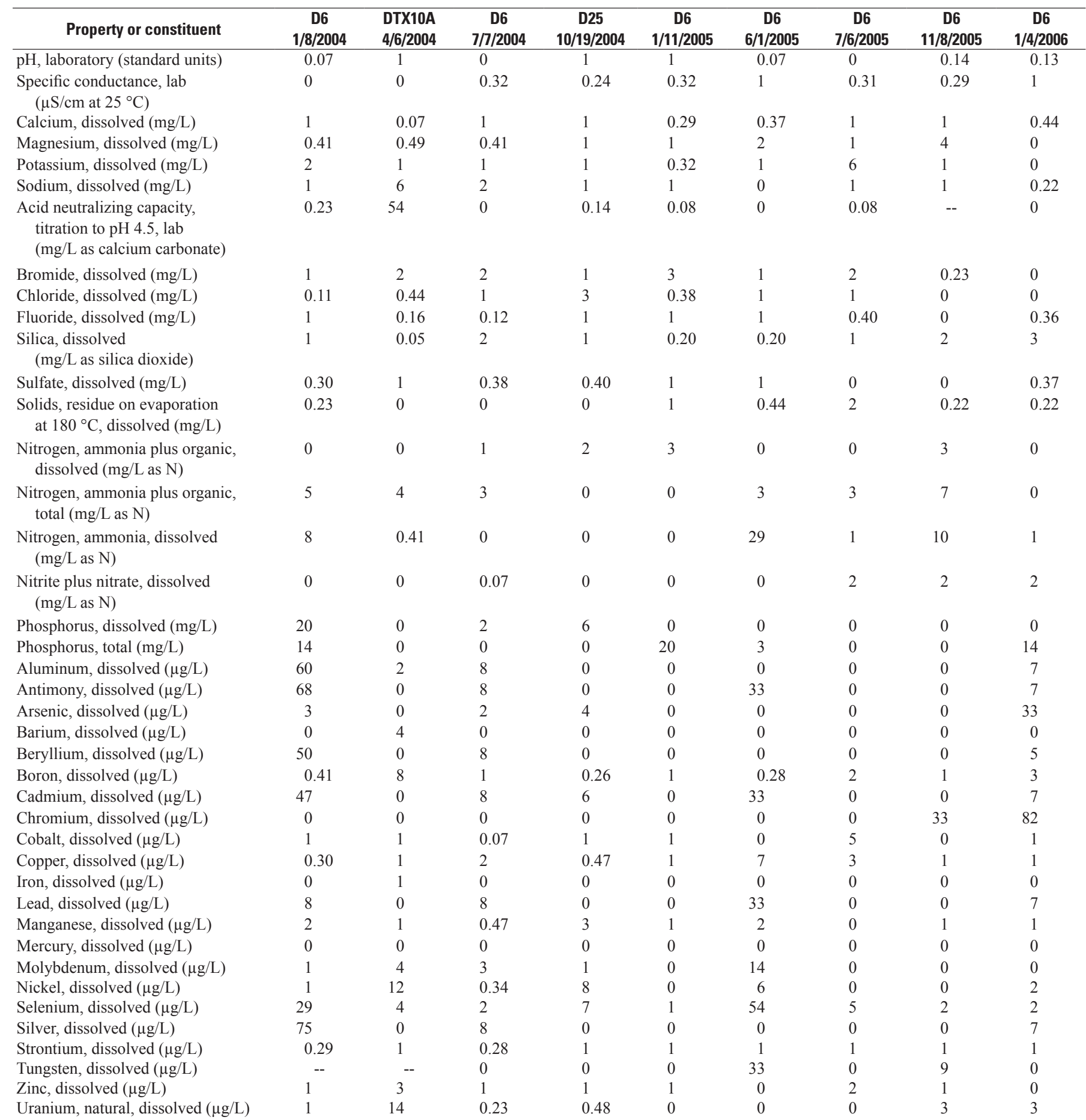


Appendix 7. Relative standard deviation for replicate groundwater samples collected near Deer Trail, Colorado, 2004-2010.—Continued

[Relative standard deviation is defined as ((square root $\left.\left((\text { sample value }- \text { replicate value })^{2} / 2\right)\right) /(($ sample value + replicate value $\left.) / 2)\right) \times 100$ and therefore expressed as a percentage; for this analysis, all values that were less than the minimum reporting level were set equal to the minimum reporting level and estimated values were included; calculations done on unrounded data; $\mu \mathrm{S} / \mathrm{cm}$, microsiemens per centimeter; ${ }^{\circ} \mathrm{C}$, degrees Celsius; dissolved, from filtered sample; $\mathrm{mg} / \mathrm{L}$, milligrams per liter; $\mathrm{N}$, nitrogen; total, from unfiltered sample; $\mu \mathrm{g} / \mathrm{L}$, micrograms per liter; --, insufficient data to determine]

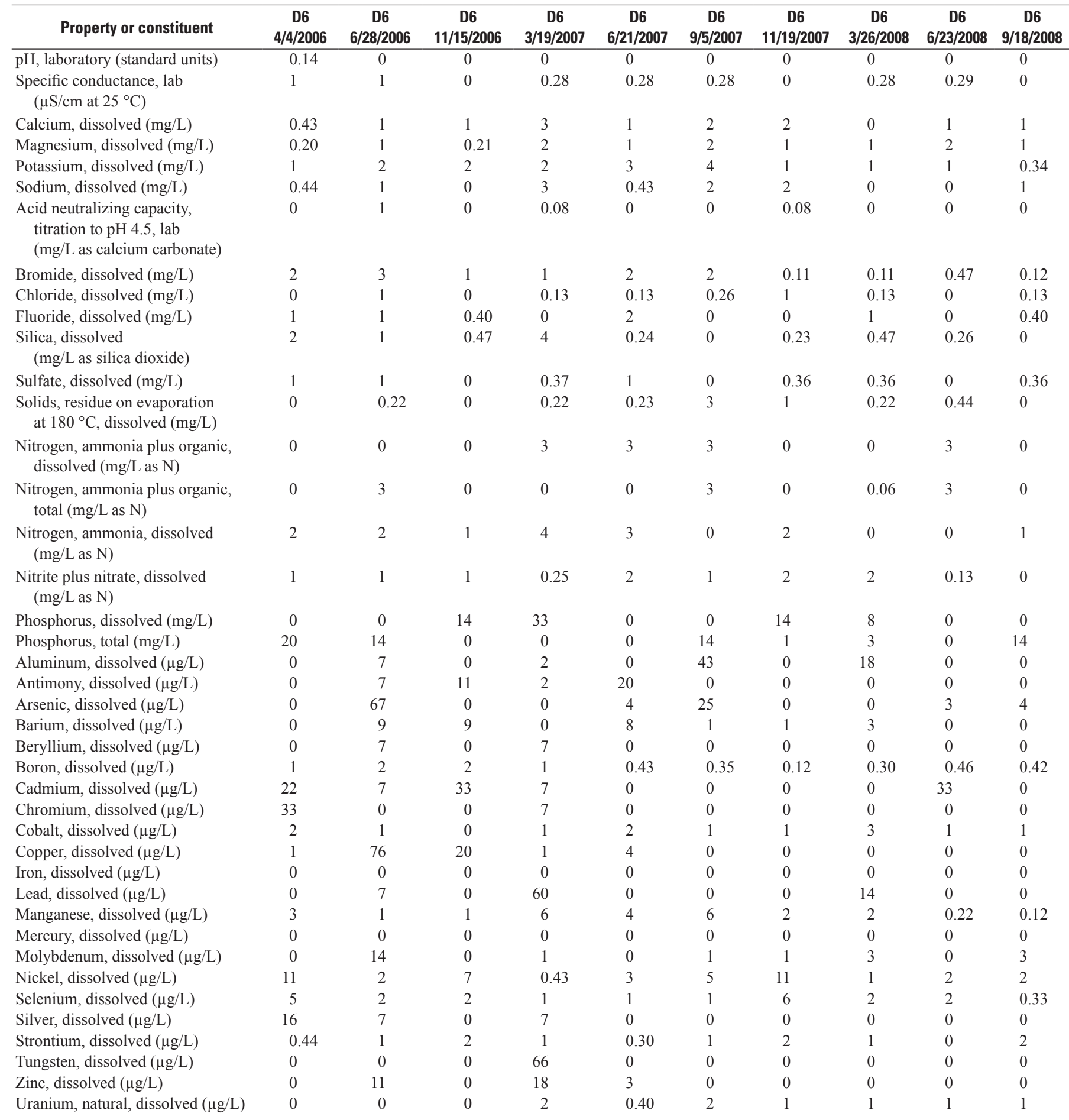


Appendix 7. Relative standard deviation for replicate groundwater samples collected near Deer Trail, Colorado, 2004-2010.-Continued

[Relative standard deviation is defined as ((square root $\left.\left((\text { sample value }- \text { replicate value })^{2} / 2\right)\right) /(($ sample value + replicate value $\left.) / 2)\right) \times 100$ and therefore expressed as a percentage; for this analysis, all values that were less than the minimum reporting level were set equal to the minimum reporting level and estimated values were included; calculations done on unrounded data; $\mu \mathrm{S} / \mathrm{cm}$, microsiemens per centimeter; ${ }^{\circ} \mathrm{C}$, degrees Celsius; dissolved, from filtered sample; $\mathrm{mg} / \mathrm{L}$, milligrams per liter; $\mathrm{N}$, nitrogen; total, from unfiltered sample; $\mu \mathrm{g} / \mathrm{L}$, micrograms per liter; --, insufficient data to determine]

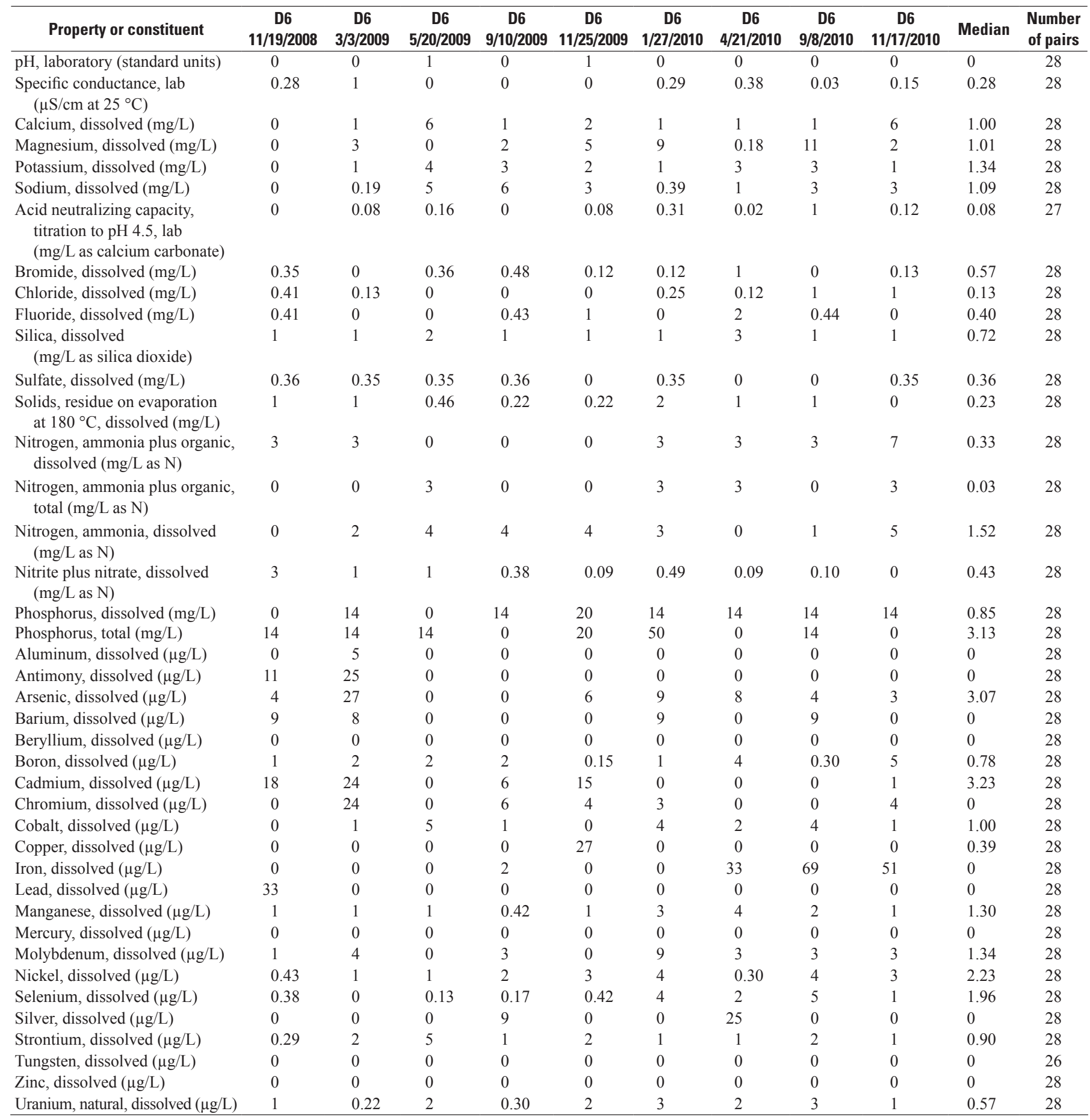


Appendix 8. Absolute difference for replicate groundwater samples collected near Deer Trail, Colorado, 2004-2010.

[Absolute difference is defined as (|sample value - replicate value|) and is in the same units as the concentration data; for this analysis, all values that were less than the minimum reporting level were set equal to the minimum reporting level and estimated values were included; calculations done on unrounded data; $\mu \mathrm{S} / \mathrm{cm}$, microsiemens per centimeter; ${ }^{\circ} \mathrm{C}$, degrees Celsius; dissolved, from filtered sample; $\mathrm{mg} / \mathrm{L}$, milligrams per liter; N, nitrogen; total, from unfiltered sample; $\mu \mathrm{g} / \mathrm{L}$, micrograms per liter; --, insufficient data to determine]

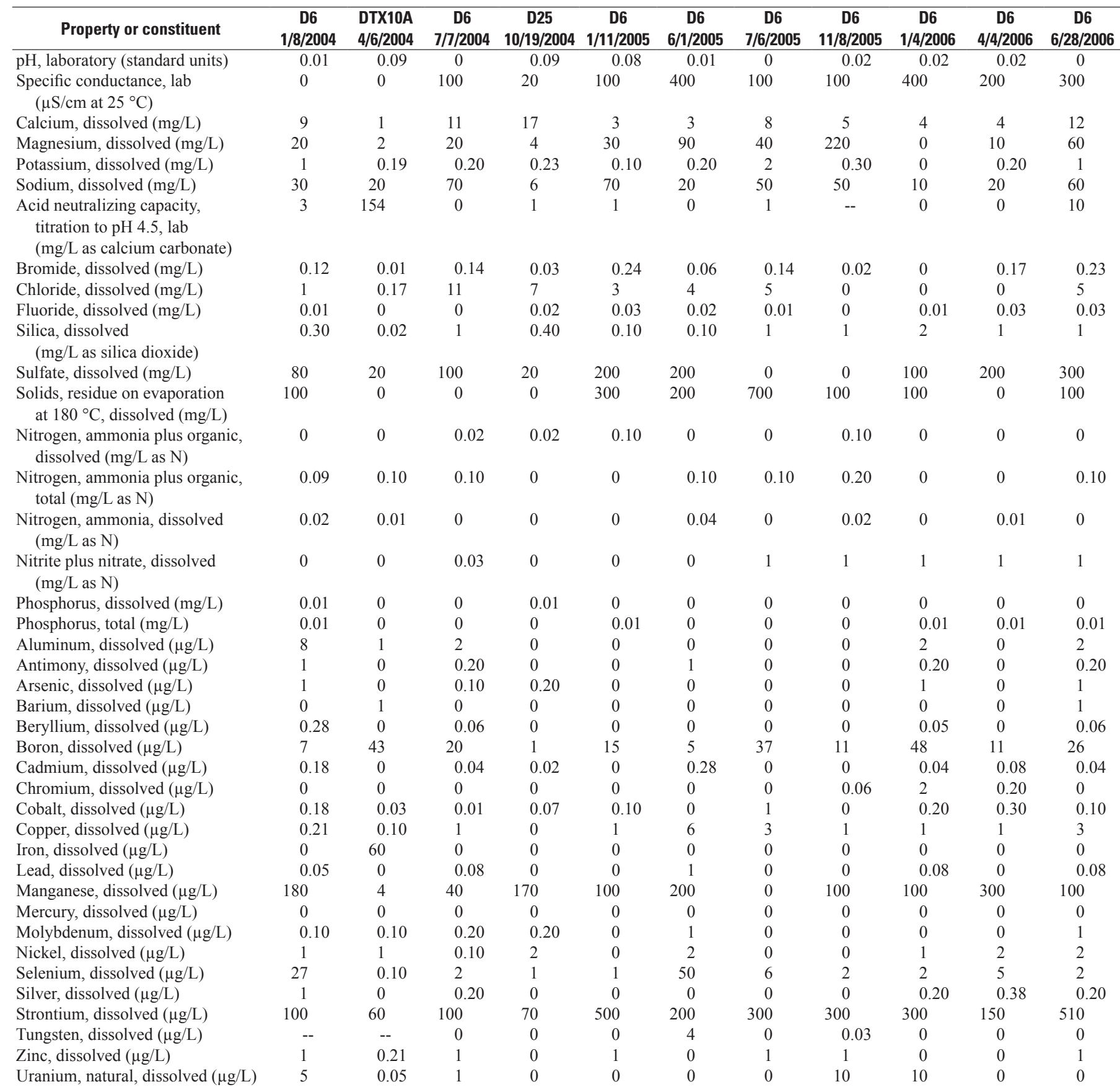


Appendix 8. Absolute difference for replicate groundwater samples collected near Deer Trail, Colorado, 2004-2010.—Continued

[Absolute difference is defined as (|sample value - replicate value $\mid)$ and is in the same units as the concentration data; for this analysis, all values that were less than the minimum reporting level were set equal to the minimum reporting level and estimated values were included; calculations done on unrounded data; $\mu \mathrm{S} / \mathrm{cm}$, microsiemens per centimeter; ${ }^{\circ} \mathrm{C}$, degrees Celsius; dissolved, from filtered sample; $\mathrm{mg} / \mathrm{L}$, milligrams per liter; $\mathrm{N}$, nitrogen; total, from unfiltered sample; $\mu \mathrm{g} / \mathrm{L}$, micrograms per liter; --, insufficient data to determine]

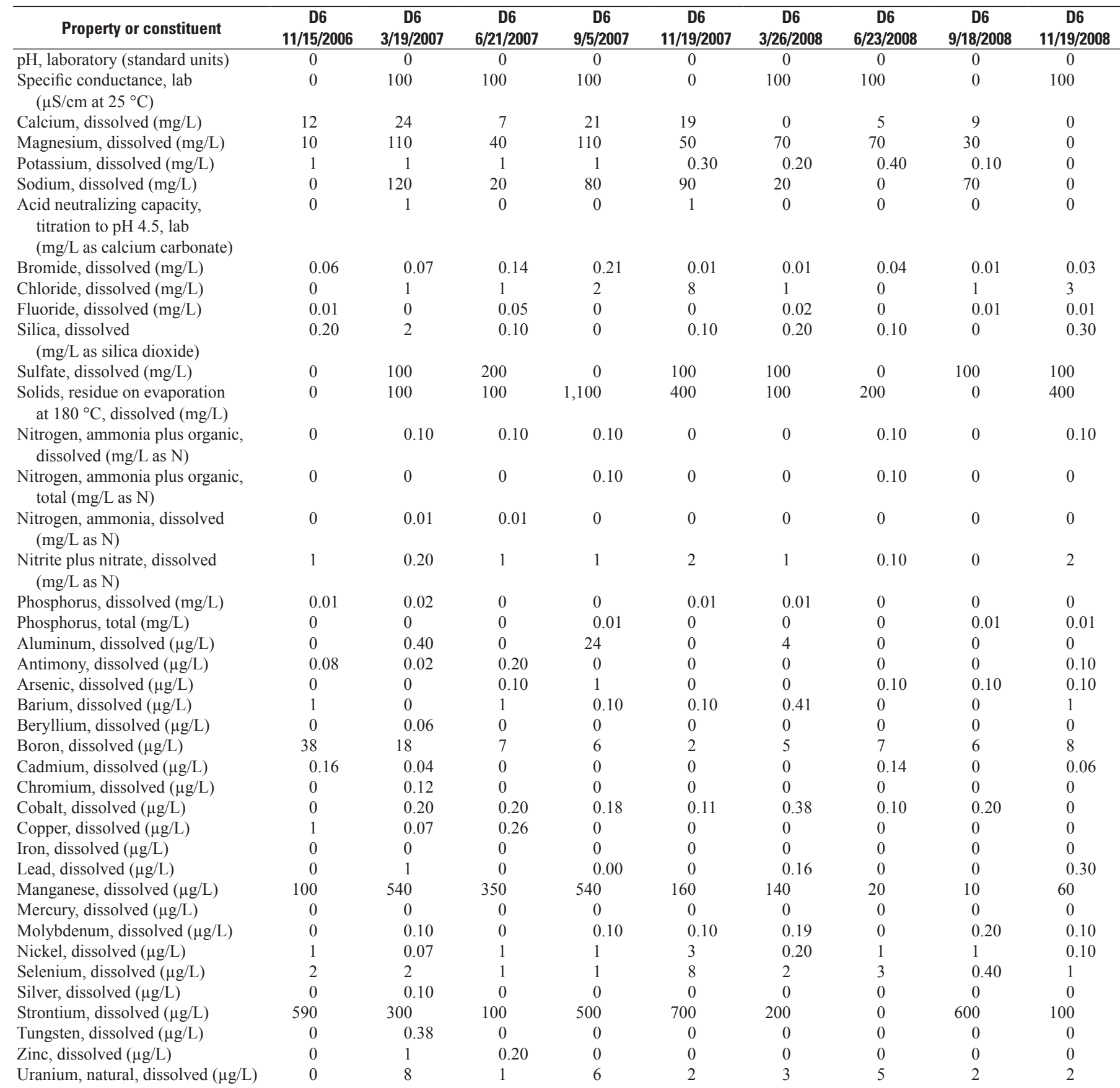


Appendix 8. Absolute difference for replicate groundwater samples collected near Deer Trail, Colorado, 2004-2010.—Continued

[Absolute difference is defined as (|sample value - replicate value|) and is in the same units as the concentration data; for this analysis, all values that were less than the minimum reporting level were set equal to the minimum reporting level and estimated values were included; calculations done on unrounded data; $\mu \mathrm{S} / \mathrm{cm}$, microsiemens per centimeter; ${ }^{\circ} \mathrm{C}$, degrees Celsius; dissolved, from filtered sample; $\mathrm{mg} / \mathrm{L}$, milligrams per liter; $\mathrm{N}$, nitrogen; total, from unfiltered sample; $\mu \mathrm{g} / \mathrm{L}$, micrograms per liter; --, insufficient data to determine]

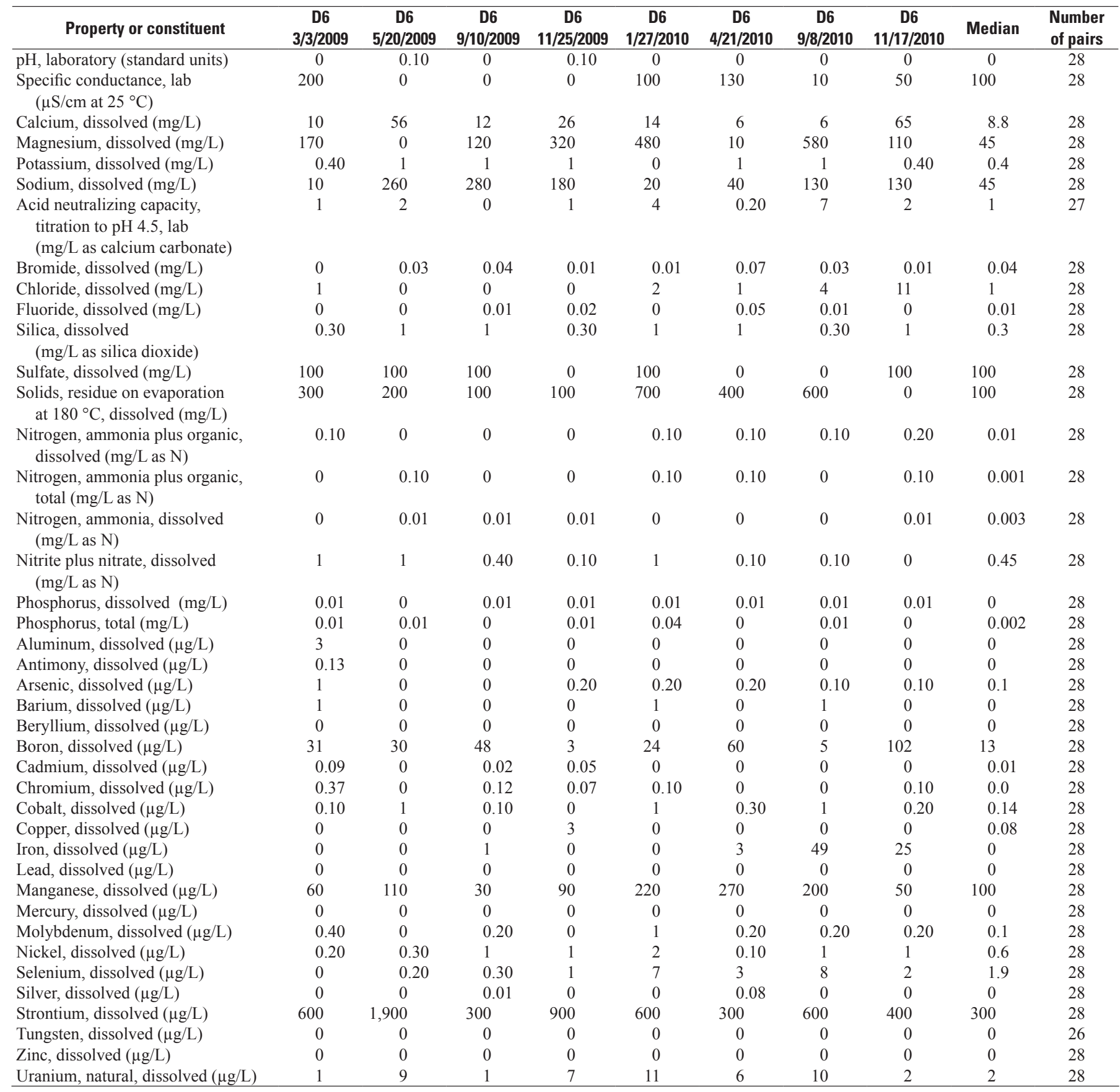


Appendix 9. Percent difference for replicate groundwater samples collected near Deer Trail, Colorado, 2004-2010.

[Percent difference is defined as [ $\mid$ sample value - replicate value $/[($ sample value + replicate value $) / 2]] \times 100$; for this analysis, all values that were less than the minimum reporting level were set equal to the minimum reporting level and estimated values were included; calculations done on unrounded data; $\mu \mathrm{S} / \mathrm{cm}$, microsiemens per centimeter; ${ }^{\circ} \mathrm{C}$, degrees Celsius; $\mathrm{mg} / \mathrm{L}$, milligrams per liter; $\mathrm{N}$, nitrogen; $\mu \mathrm{g} / \mathrm{L}$, micrograms per liter; --, insufficient data to determine]

\begin{tabular}{|c|c|c|c|c|c|c|c|c|c|c|}
\hline Property or constituent & $\begin{array}{c}\text { D6 } \\
1 / 8 / 2004 \\
\end{array}$ & $\begin{array}{l}\text { DTX10A } \\
4 / 6 / 2004\end{array}$ & $\begin{array}{c}\text { D6 } \\
7 / 7 / 2004 \\
\end{array}$ & $\begin{array}{c}\text { D25 } \\
10 / 19 / 2004\end{array}$ & $\begin{array}{c}\text { D6 } \\
1 / 11 / 2005 \\
\end{array}$ & $\begin{array}{c}\text { D6 } \\
6 / 1 / 2005 \\
\end{array}$ & $\begin{array}{c}\text { D6 } \\
7 / 6 / 2005\end{array}$ & $\begin{array}{c}\text { D6 } \\
11 / 8 / 2005 \\
\end{array}$ & $\begin{array}{c}\text { D6 } \\
1 / 4 / 2006 \\
\end{array}$ & $\begin{array}{c}\text { D6 } \\
4 / 4 / 2006\end{array}$ \\
\hline $\mathrm{pH}$, laboratory (standard units) & 0 & 1 & 0 & 1.2 & 1.1 & 0 & 0 & 0 & 0 & 0 \\
\hline $\begin{array}{l}\text { Specific conductance, lab } \\
\left(\mu \mathrm{S} / \mathrm{cm} \text { at } 25^{\circ} \mathrm{C}\right)\end{array}$ & 0 & 0 & 0.6 & 0.5 & 0.6 & 2 & 0.6 & 0.6 & 2 & 1.2 \\
\hline Calcium, dissolved (mg/L) & 2 & 0 & 2 & 2 & 0.6 & 0.7 & 2 & 1.0 & 0.9 & 0.9 \\
\hline Magnesium, dissolved (mg/L) & 0.8 & 1.0 & 0.8 & 2 & 1.2 & 3 & 1.5 & 8 & 0 & 0.4 \\
\hline Potassium, dissolved (mg/L) & 3 & 2 & 2 & 3 & 0.6 & 1.3 & 12 & 2 & 0 & 1.3 \\
\hline Sodium, dissolved (mg/L) & 1.4 & 12 & 3 & 2 & 3 & 0.9 & 2 & 2 & 0.4 & 0.9 \\
\hline $\begin{array}{l}\text { Acid neutralizing capacity, } \\
\text { titration to } \mathrm{pH} 4.5 \text {, lab } \\
\text { (mg/L as calcium carbonate) }\end{array}$ & 0.5 & 108 & 0 & 0.3 & 0.2 & 0 & 0.2 & & 0 & 0 \\
\hline Bromide, dissolved (mg/L) & 3 & 4 & 3 & 2 & 6 & 1.4 & 3 & 0.5 & 0 & 4 \\
\hline Chloride, dissolved (mg/L) & 0.2 & 0.9 & 3 & 6 & 0.8 & 1.0 & 1.3 & 0 & 0 & 0 \\
\hline Fluoride, dissolved (mg/L) & 1.0 & 0 & 0 & 2 & 2 & 2 & 0.8 & 0 & 0.7 & 2 \\
\hline $\begin{array}{l}\text { Silica, dissolved } \\
\text { (mg/L as silica dioxide) }\end{array}$ & 1.3 & 0 & 4 & 1.3 & 0.4 & 0.4 & 2 & 3 & 7 & 4 \\
\hline Sulfate, dissolved (mg/L) & 0.6 & 1.1 & 0.8 & 0.8 & 1.5 & 1.5 & 0 & 0 & 0.7 & 1.5 \\
\hline $\begin{array}{l}\text { Solids, residue on evaporation } \\
\text { at } 180{ }^{\circ} \mathrm{C} \text {, dissolved }(\mathrm{mg} / \mathrm{L})\end{array}$ & 0.5 & 0 & 0 & 0 & 1.4 & 0.9 & 3 & 0.4 & 0.4 & 0 \\
\hline $\begin{array}{l}\text { Nitrogen, ammonia plus organic, } \\
\text { dissolved (mg/L as } \mathrm{N})\end{array}$ & 0 & 0 & 1.3 & 4 & 6 & 0 & 0 & 6 & 0 & 0 \\
\hline $\begin{array}{l}\text { Nitrogen, ammonia plus organic, } \\
\text { total (mg/L as } \mathrm{N})\end{array}$ & 9 & 7 & 6 & 0 & 0 & 6 & 6 & 13 & 0 & 0 \\
\hline $\begin{array}{l}\text { Nitrogen, ammonia, dissolved } \\
\quad(\mathrm{mg} / \mathrm{L} \text { as } \mathrm{N})\end{array}$ & 17 & 0.8 & 0 & 0 & 0 & 58 & 2 & 19 & 1.3 & 4 \\
\hline $\begin{array}{l}\text { Nitrite plus nitrate, dissolved } \\
(\mathrm{mg} / \mathrm{L} \text { as } \mathrm{N})\end{array}$ & 0 & 0 & 0 & 0 & 0 & 0 & 3 & 3 & 3 & 3 \\
\hline Phosphorus, dissolved (mg/L) & 40 & 0 & 3 & 12 & 0 & 0 & 0 & 0 & 0 & 0 \\
\hline Phosphorus, total (mg/L) & 29 & 0 & 0 & 0 & 40 & 6 & 0 & 0 & 29 & 40 \\
\hline Aluminum, dissolved $(\mu \mathrm{g} / \mathrm{L})$ & 121 & 4 & 15 & 0 & 0 & 0 & 0 & 0 & 13 & 0 \\
\hline Antimony, dissolved $(\mu \mathrm{g} / \mathrm{L})$ & 135 & 0 & 15 & 0 & 0 & 67 & 0 & 0 & 13 & 0 \\
\hline Arsenic, dissolved $(\mu \mathrm{g} / \mathrm{L})$ & 6 & 0 & 5 & 8 & 0 & 0 & 0 & 0 & 67 & 0 \\
\hline Barium, dissolved $(\mu \mathrm{g} / \mathrm{L})$ & 0 & 9 & 0 & 0 & 0 & 0 & 0 & 0 & 0 & 0 \\
\hline Beryllium, dissolved $(\mu \mathrm{g} / \mathrm{L})$ & 100 & 0 & 15 & 0 & 0 & 0 & 0 & 0 & 11 & 0 \\
\hline Boron, dissolved $(\mu \mathrm{g} / \mathrm{L})$ & 0.8 & 15 & 2 & 0.5 & 2 & 0.6 & 4 & 1.3 & 6 & 1.4 \\
\hline Cadmium, dissolved $(\mu \mathrm{g} / \mathrm{L})$ & 95 & 0 & 15 & 11 & 0 & 67 & 0 & 0 & 13 & 44 \\
\hline Chromium, dissolved $(\mu \mathrm{g} / \mathrm{L})$ & 0 & 0 & 0 & 0 & 0 & 0 & 0 & 67 & 164 & 67 \\
\hline Cobalt, dissolved $(\mu \mathrm{g} / \mathrm{L})$ & 2 & 2 & 0.1 & 2 & 1.3 & 0 & 10 & 0 & 3 & 4 \\
\hline Copper, dissolved ( $\mu \mathrm{g} / \mathrm{L})$ & 0.6 & 1.2 & 5 & 0.9 & 2 & 13 & 6 & 2 & 3 & 3 \\
\hline Iron, dissolved $(\mu \mathrm{g} / \mathrm{L})$ & 0 & 1.3 & 0 & 0 & 0 & 0 & 0 & 0 & 0 & 0 \\
\hline Lead, dissolved $(\mu \mathrm{g} / \mathrm{L})$ & 16 & 0 & 15 & 0 & 0 & 67 & 0 & 0 & 13 & 0 \\
\hline Manganese, dissolved $(\mu \mathrm{g} / \mathrm{L})$ & 5 & 1.4 & 0.9 & 5 & 2 & 4 & 0 & 2 & 3 & 7 \\
\hline Mercury, dissolved $(\mu \mathrm{g} / \mathrm{L})$ & 0 & 0 & 0 & 0 & 0 & 0 & 0 & 0 & 0 & 0 \\
\hline Molybdenum, dissolved $(\mu \mathrm{g} / \mathrm{L})$ & 2 & 7 & 6 & 2 & 0 & 29 & 0 & 0 & 0 & 0 \\
\hline Nickel, dissolved $(\mu \mathrm{g} / \mathrm{L})$ & 2 & 25 & 0.7 & 16 & 0 & 11 & 0 & 0 & 4 & 22 \\
\hline Selenium, dissolved $(\mu \mathrm{g} / \mathrm{L})$ & 58 & 8 & 4 & 13 & 2 & 109 & 10 & 4 & 5 & 11 \\
\hline Silver, dissolved $(\mu \mathrm{g} / \mathrm{L})$ & 150 & 0 & 15 & 0 & 0 & 0 & 0 & 0 & 13 & 31 \\
\hline Strontium, dissolved $(\mu \mathrm{g} / \mathrm{L})$ & 0.6 & 1.1 & 0.6 & 2 & 3 & 1.2 & 2 & 2 & 2 & 0.9 \\
\hline Tungsten, dissolved $(\mu \mathrm{g} / \mathrm{L})$ & -- & -- & 0 & 0 & 0 & 67 & 0 & 18 & 0 & 0 \\
\hline Zinc, dissolved $(\mu \mathrm{g} / \mathrm{L})$ & 2 & 5 & 2 & 2 & 3 & 0 & 3 & 3 & 0 & 0 \\
\hline Uranium, natural, dissolved $(\mu \mathrm{g} / \mathrm{L})$ & 3 & 29 & 0.5 & 1.0 & 0 & 0 & 0 & 6 & 6 & 0 \\
\hline
\end{tabular}


Appendix 9. Percent difference for replicate groundwater samples collected near Deer Trail, Colorado, 2004-2010.—Continued

[Percent difference is defined as [ sample value - replicate value $/[$ (sample value + replicate value) $/ 2]] \times 100$; for this analysis, all values that were less than the minimum reporting level were set equal to the minimum reporting level and estimated values were included; calculations done on unrounded data; $\mu \mathrm{S} / \mathrm{cm}$, microsiemens per centimeter; ${ }^{\circ} \mathrm{C}$, degrees Celsius; $\mathrm{mg} / \mathrm{L}$, milligrams per liter; $\mathrm{N}$, nitrogen; $\mu \mathrm{g} / \mathrm{L}$, micrograms per liter; --, insufficient data to determine ]

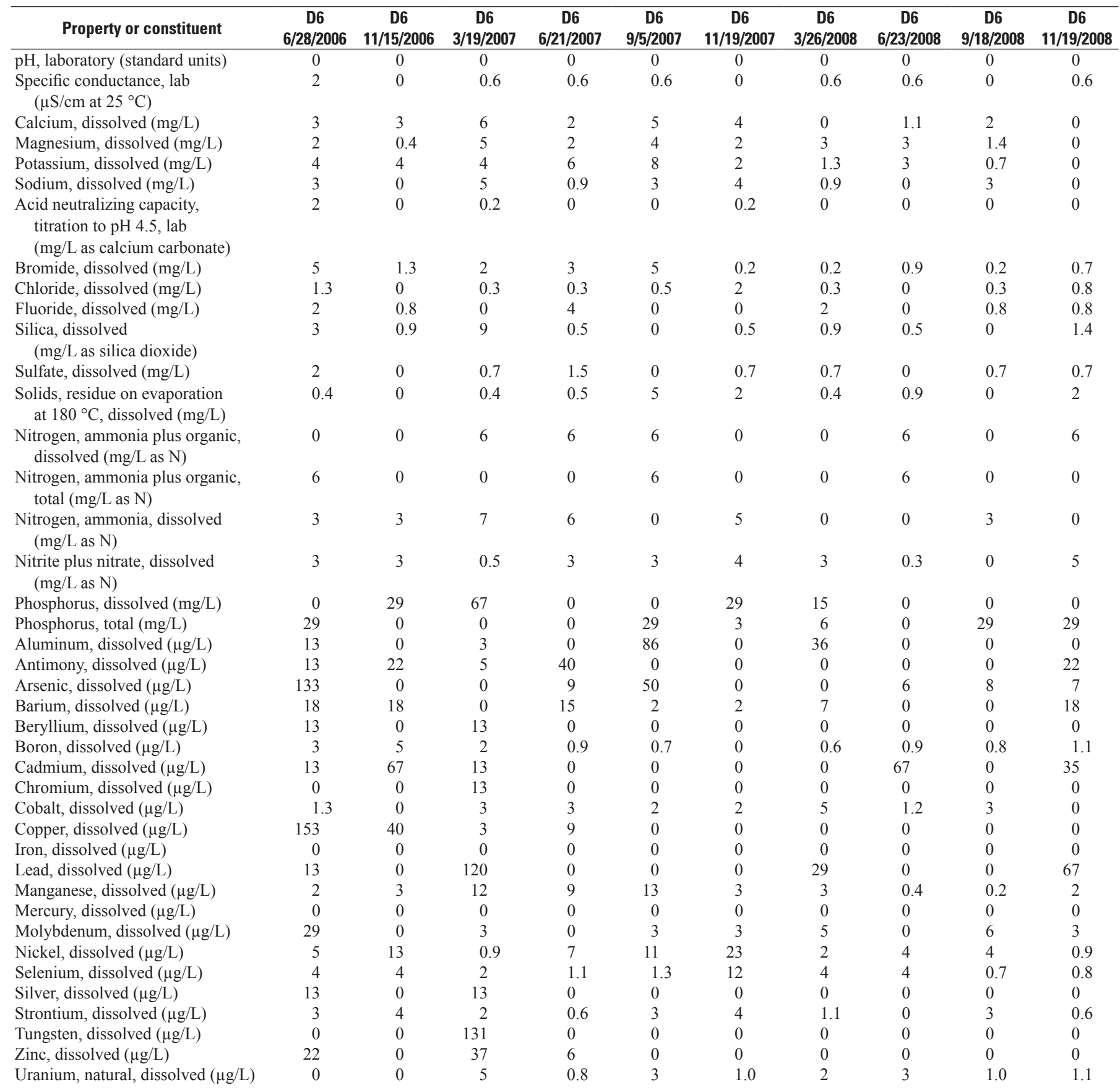


Appendix 9. Percent difference for replicate groundwater samples collected near Deer Trail, Colorado, 2004-2010._Continued

[Percent difference is defined as [|sample value - replicate value $/[($ sample value + replicate value $) / 2]] \times 100$; for this analysis, all values that were less than the minimum reporting level were set equal to the minimum reporting level and estimated values were included; calculations done on unrounded data; $\mu \mathrm{S} / \mathrm{cm}$, microsiemens per centimeter; ${ }^{\circ} \mathrm{C}$, degrees Celsius; $\mathrm{mg} / \mathrm{L}$, milligrams per liter; $\mathrm{N}$, nitrogen; $\mu \mathrm{g} / \mathrm{L}$, micrograms per liter; --, insufficient data to determine]

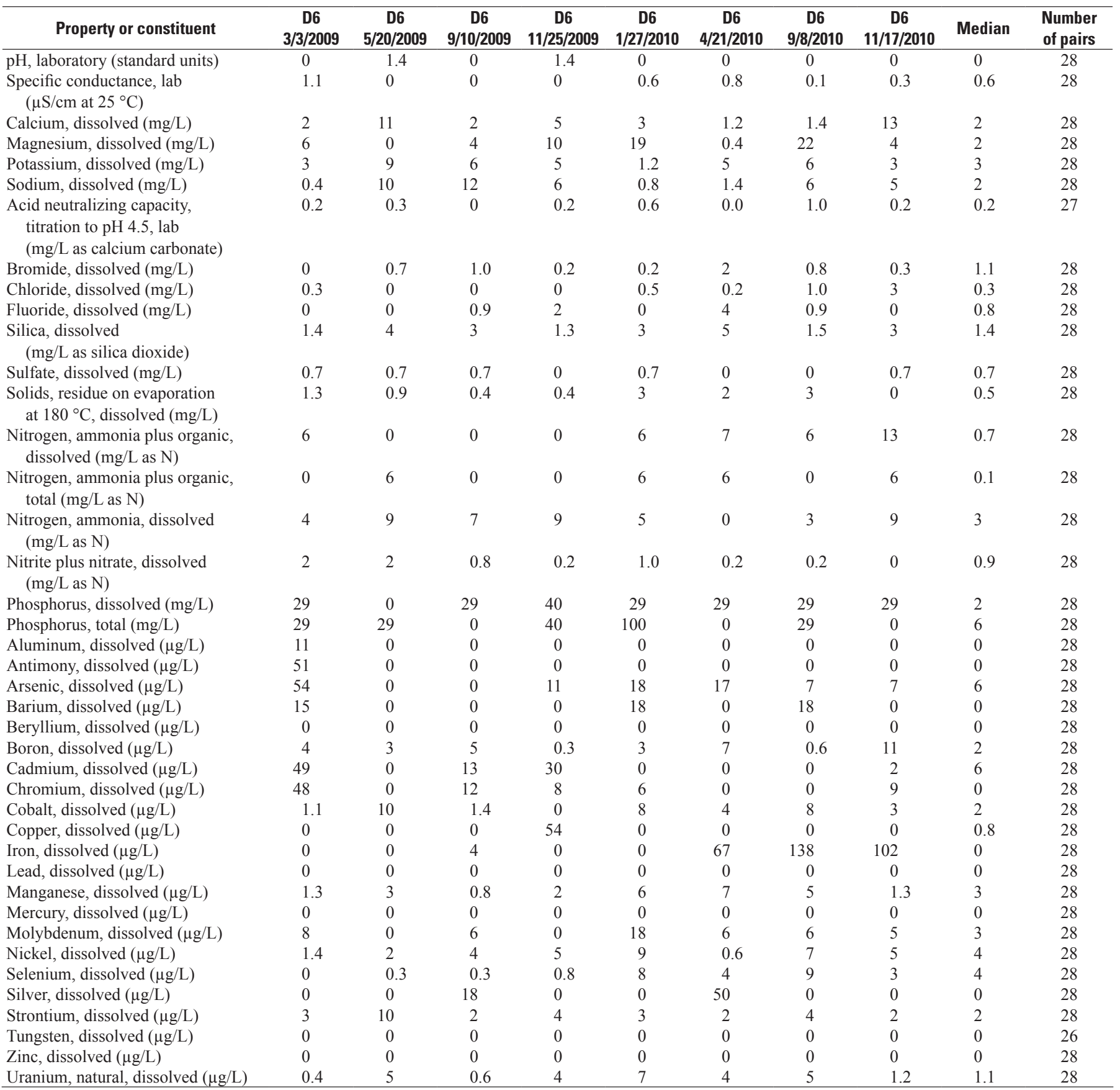


Appendix 10. Statistical comparison of concentrations for selected dissolved constituents in groundwater samples collected near Deer Trail, Colorado, 2004-2010, and waterquality standards.

[Units for concentration data are milligrams per liter for nitrate and micrograms per liter for arsenic, cadmium, chromium, copper, lead, mercury, molybdenum, nickel, selenium, silver, uranium, and zinc; --, not applicable; <, less than; >, greater than; standard is from Colorado Department of Public Health and Environment (2009); H, health-based standard; A, agricultural standard]

\begin{tabular}{|c|c|c|c|c|c|c|c|c|c|c|}
\hline Well & $\begin{array}{l}\text { Number of } \\
\text { samples for } \\
\text { statistical } \\
\text { comparison }\end{array}$ & $\begin{array}{c}\text { Minimum } \\
\text { groundwater } \\
\text { value used for } \\
\text { statistical } \\
\text { comparison }\end{array}$ & $\begin{array}{l}\text { Maximum } \\
\text { groundwater } \\
\text { value used for } \\
\text { statistical } \\
\text { comparison }\end{array}$ & $\begin{array}{c}\text { Median } \\
\text { groundwater } \\
\text { value used for } \\
\text { statistical } \\
\text { comparison' }\end{array}$ & $\begin{array}{l}\text { Colorado } \\
\text { standard }\end{array}$ & $\begin{array}{l}\text { Type of } \\
\text { regulatory } \\
\text { standard }\end{array}$ & $\begin{array}{c}\text { Percentage } \\
\text { of sample } \\
\text { values that were } \\
\text { higher than the } \\
\text { standard }\end{array}$ & $\begin{array}{c}90 \text { percent } \\
\text { prediction interval } \\
\text { (alpha }=0.10 \text { ) } \\
\text { for the data }{ }^{2}\end{array}$ & $\begin{array}{c}p \text {-value } \\
\text { for sign } \\
\text { test }^{3}\end{array}$ & $\begin{array}{c}\text { Are concentrations } \\
\text { significantly } \\
\text { (alpha }=0.05 \text { ) } \\
\text { higher than the } \\
\text { regulatory standard? }\end{array}$ \\
\hline \multicolumn{11}{|c|}{ Nitrate $^{4}$} \\
\hline DTX1 & 23 & 1.2 & 4.5 & 3.0 & 10 & $\mathrm{H}$ & 0 & $1.20-4.29$ & $>0.9$ & No \\
\hline DTX2 & 27 & $<0.02$ & $<0.4$ & $<0.04$ & 10 & $\mathrm{H}$ & 0 & $0-<0.40$ & $>0.9$ & No \\
\hline D6 & 27 & 21.70 & 53.80 & 40.40 & 10 & $\mathrm{H}$ & 100 & $22.1-53.0$ & 0.000 & Yes \\
\hline D6 & 27 & 21.70 & 53.80 & 40.40 & 100 & A & 0 & $22.1-53.0$ & $>0.9$ & No \\
\hline D17 & 23 & 0.75 & 1.17 & 0.88 & 10 & $\mathrm{H}$ & 0 & $0.75-1.14$ & $>0.9$ & No \\
\hline D25 & 27 & 0.02 & 4.54 & 0.44 & 10 & $\mathrm{H}$ & 0 & $0.02--3.71$ & $>0.9$ & No \\
\hline \multicolumn{11}{|c|}{ Arsenic } \\
\hline DTX1 & 23 & 1.3 & 2.8 & 1.6 & 10 & $\mathrm{H}$ & 0 & $1.3-2.4$ & $>0.9$ & No \\
\hline DTX2 & 27 & 0.3 & 1.8 & 0.8 & 10 & $\mathrm{H}$ & 0 & $0.36-1.4$ & $>0.9$ & No \\
\hline D6 & 27 & 0.18 & 10.5 & 1.3 & 10 & $\mathrm{H}$ & 7.4 & $0.45-10.1$ & $>0.9$ & No \\
\hline D17 & 23 & 1.3 & 1.8 & 1.5 & 10 & $\mathrm{H}$ & 0 & $1.3-1.7$ & $>0.9$ & No \\
\hline D25 & 27 & 1.1 & 3.5 & 1.7 & 10 & $\mathrm{H}$ & 0 & $1.2-3.1$ & $>0.9$ & No \\
\hline \multicolumn{11}{|c|}{ Cadmium } \\
\hline DTX1 & 23 & 0.10 & 0.26 & 0.16 & 5 & $\mathrm{H}$ & 0 & $0.10-0.24$ & $>0.9$ & No \\
\hline DTX2 & 27 & 0.03 & $<0.24$ & $<0.24$ & 5 & $\mathrm{H}$ & 0 & $0-<0.24$ & $>0.9$ & No \\
\hline D6 & 27 & 0.09 & $<1.0$ & $<1.0$ & 5 & $\mathrm{H}$ & 0 & $0-<1$ & $>0.9$ & No \\
\hline D17 & 23 & 0.02 & $<0.08$ & 0.08 & 5 & $\mathrm{H}$ & 0 & $0-<0.08$ & $>0.9$ & No \\
\hline $\mathrm{D} 25$ & 27 & $<0.08$ & 0.25 & 0.20 & 5 & $\mathrm{H}$ & 0 & $<0.08-0.24$ & $>0.9$ & No \\
\hline \multicolumn{11}{|c|}{ Chromium } \\
\hline DTX1 & 23 & 0.04 & $<1.2$ & $<1.2$ & 100 & $\mathrm{H}, \mathrm{A}$ & 0 & $0-<1.2$ & $>0.9$ & No \\
\hline DTX2 & 27 & $<0.02$ & $<8$ & $<0.36$ & 100 & $\mathrm{H}, \mathrm{A}$ & 0 & $0-<8$ & $>0.9$ & No \\
\hline D6 & 27 & $<0.04$ & $<3.0$ & $<3.0$ & 100 & $\mathrm{H}, \mathrm{A}$ & 0 & $0-<3$ & $>0.9$ & No \\
\hline D17 & 23 & 0.02 & $<0.8$ & $<0.8$ & 100 & $\mathrm{H}, \mathrm{A}$ & 0 & $0-<0.8$ & $>0.9$ & No \\
\hline $\mathrm{D} 25$ & 27 & 0.02 & $<8$ & $<8$ & 100 & $\mathrm{H}, \mathrm{A}$ & 0 & $0-<8$ & $>0.9$ & No \\
\hline \multicolumn{11}{|c|}{ Copper } \\
\hline DTX1 & 23 & 0.6 & $<10$ & $<10$ & 200 & $\mathrm{~A}$ & 0 & $0-<10$ & $>0.9$ & No \\
\hline DTX2 & 27 & $<0.4$ & 11.8 & $<4$ & 200 & $\mathrm{~A}$ & 0 & $<5-11.2$ & $>0.9$ & No \\
\hline D6 & 27 & 0.41 & 49.1 & $<10$ & 200 & $\mathrm{~A}$ & 0 & $<20-48.1$ & $>0.9$ & No \\
\hline D17 & 23 & 0.21 & $<2$ & $<2$ & 200 & A & 0 & $0-<2$ & $>0.9$ & No \\
\hline $\mathrm{D} 25$ & 27 & 0.48 & 15.2 & $<10$ & 200 & A & 0 & $<6-12.4$ & $>0.9$ & No \\
\hline
\end{tabular}


Appendix 10. Statistical comparison of concentrations for selected dissolved constituents in groundwater samples collected near Deer Trail, Colorado, 2004-2010, and waterquality standards.-Continued

[Units for concentration data are milligrams per liter for nitrate and micrograms per liter for arsenic, cadmium, chromium, copper, lead, mercury, molybdenum, nickel, selenium, silver, uranium, and zinc; --, not applicable; <, less than; >, greater than; standard is from Colorado Department of Public Health and Environment (2009); H, health-based standard; A, agricultural standard]

\begin{tabular}{|c|c|c|c|c|c|c|c|c|c|c|}
\hline Well & $\begin{array}{l}\text { Number of } \\
\text { samples for } \\
\text { statistical } \\
\text { comparison }\end{array}$ & $\begin{array}{c}\text { Minimum } \\
\text { groundwater } \\
\text { value used for } \\
\text { statistical } \\
\text { comparison }\end{array}$ & $\begin{array}{l}\text { Maximum } \\
\text { groundwater } \\
\text { value used for } \\
\text { statistical } \\
\text { comparison }\end{array}$ & $\begin{array}{c}\text { Median } \\
\text { groundwater } \\
\text { value used for } \\
\text { statistical } \\
\text { comparison }^{1}\end{array}$ & $\begin{array}{l}\text { Colorado } \\
\text { standard }\end{array}$ & $\begin{array}{l}\text { Type of } \\
\text { regulatory } \\
\text { standard }\end{array}$ & $\begin{array}{c}\text { Percentage } \\
\text { of sample } \\
\text { values that were } \\
\text { higher than the } \\
\text { standard }\end{array}$ & $\begin{array}{l}90 \text { percent } \\
\text { prediction interval } \\
\text { (alpha }=0.10 \text { ) } \\
\text { for the data }^{2}\end{array}$ & $\begin{array}{c}p \text {-value } \\
\text { for sign } \\
\text { test }^{3}\end{array}$ & $\begin{array}{c}\text { Are concentrations } \\
\text { significantly } \\
\text { (alpha }=0.05 \text { ) } \\
\text { higher than the } \\
\text { regulatory standard? }\end{array}$ \\
\hline \multicolumn{11}{|c|}{ Lead } \\
\hline$\overline{\text { DTX1 }}$ & 23 & $<0.03$ & $<0.4$ & $<0.16$ & 50 & $\mathrm{H}$ & 0 & $0-<0.4$ & $>0.9$ & No \\
\hline DTX2 & 27 & $<0.04$ & $<0.4$ & $<0.16$ & 50 & $\mathrm{H}$ & 0 & $0-<0.4$ & $>0.9$ & No \\
\hline D6 & 27 & $<0.08$ & $<3.0$ & $<0.6$ & 50 & $\mathrm{H}$ & 0 & $0-<3$ & $>0.9$ & No \\
\hline D17 & 23 & $<0.01$ & $<0.16$ & $<0.08$ & 50 & $\mathrm{H}$ & 0 & $0-<0.16$ & $>0.9$ & No \\
\hline $\mathrm{D} 25$ & 27 & $<0.03$ & $<0.4$ & $<0.16$ & 50 & $\mathrm{H}$ & 0 & $0-<0.4$ & $>0.9$ & No \\
\hline \multicolumn{11}{|c|}{ Mercury } \\
\hline$\overline{\text { DTX1 }}$ & 23 & $<0.005$ & $<0.01$ & $<0.01$ & 2 & $\mathrm{H}$ & 0 & $0-<0.01$ & $>0.9$ & No \\
\hline DTX2 & 27 & $<0.005$ & $<0.02$ & $<0.01$ & 2 & $\mathrm{H}$ & 0 & $0-<0.02$ & $>0.9$ & No \\
\hline D6 & 27 & $<0.005$ & $<0.02$ & $<0.01$ & 2 & $\mathrm{H}$ & 0 & $0-<0.02$ & $>0.9$ & No \\
\hline D17 & 23 & $<0.005$ & $<0.01$ & $<0.01$ & 2 & $\mathrm{H}$ & 0 & $0-<0.01$ & $>0.9$ & No \\
\hline D25 & 27 & $<0.005$ & $<0.02$ & $<0.01$ & 2 & $\mathrm{H}$ & 0 & $0-<0.02$ & $>0.9$ & No \\
\hline \multicolumn{11}{|c|}{ Molybdenum } \\
\hline $\begin{array}{l}\text { DTX1 } \\
\end{array}$ & 23 & 1.5 & 6.4 & 3.5 & 35 & $\mathrm{H}$ & 0 & $1.5-6.2$ & $>0.9$ & No \\
\hline DTX2 & 27 & 1.5 & 2.0 & 1.7 & 35 & $\mathrm{H}$ & 0 & $1.5-2.0$ & $>0.9$ & No \\
\hline D6 & 27 & 3.0 & 5.1 & 3.6 & 35 & $\mathrm{H}$ & 0 & $3.0-4.2$ & $>0.9$ & No \\
\hline D17 & 23 & 5.3 & 6.3 & 5.6 & 35 & $\mathrm{H}$ & 0 & $5.3-6.1$ & $>0.9$ & No \\
\hline D25 & 27 & 5.8 & 11.7 & 7.3 & 35 & $\mathrm{H}$ & 0 & $5.9-10.1$ & $>0.9$ & No \\
\hline \multicolumn{11}{|c|}{ Nickel } \\
\hline $\begin{array}{l}\text { DTX1 } \\
\text { D }\end{array}$ & 23 & 4 & 48.3 & 17.8 & 100 & $\mathrm{H}$ & 0 & $4.0-41.1$ & $>0.9$ & No \\
\hline DTX2 & 27 & 4.2 & 36.4 & 8.8 & 100 & $\mathrm{H}$ & 0 & $4.2-32.5$ & $>0.9$ & No \\
\hline D6 & 27 & 7.1 & 42.1 & 14.3 & 100 & $\mathrm{H}$ & 0 & $7.4-26.3$ & $>0.9$ & No \\
\hline D17 & 23 & $<0.5$ & 3.6 & 0.82 & 100 & $\mathrm{H}$ & 0 & $0.50-3.02$ & $>0.9$ & No \\
\hline $\mathrm{D} 25$ & 27 & 3.4 & 36.3 & 8.8 & 100 & $\mathrm{H}$ & 0 & $3.5-25.9$ & $>0.9$ & No \\
\hline \multicolumn{11}{|c|}{ Selenium } \\
\hline$\overline{\text { DTX1 }}$ & 23 & 1.9 & 20.1 & 11.7 & 20 & $\mathrm{~A}$ & 4.3 & $1.9-15.8$ & $>0.9$ & No \\
\hline DTX2 & 27 & 0.08 & 4.5 & 0.23 & 20 & A & 0 & $0.09-2.6$ & $>0.9$ & No \\
\hline D6 & 27 & 20.7 & 119 & 62.9 & 20 & A & 100 & $25.1-97.7$ & 0.000 & Yes \\
\hline D6 & 27 & 20.7 & 119 & 62.9 & 50 & $\mathrm{H}$ & 74 & $25.1-97.7$ & 0.003 & Yes \\
\hline D17 & 23 & 6.2 & 9.1 & 7.7 & 20 & A & 0 & $6.2-9.0$ & $>0.9$ & No \\
\hline D25 & 27 & 0.2 & 20.5 & 1.4 & 20 & A & 0 & $0.21-7.8$ & $>0.9$ & No \\
\hline
\end{tabular}


Appendix 10. Statistical comparison of concentrations for selected dissolved constituents in groundwater samples collected near Deer Trail, Colorado, 2004-2010, and waterquality standards.-Continued

[Units for concentration data are milligrams per liter for nitrate and micrograms per liter for arsenic, cadmium, chromium, copper, lead, mercury, molybdenum, nickel, selenium, silver, uranium, and zinc; --, not applicable; <, less than; >, greater than; standard is from Colorado Department of Public Health and Environment (2009); H, health-based standard; A, agricultural standard]

\begin{tabular}{|c|c|c|c|c|c|c|c|c|c|c|}
\hline Well & $\begin{array}{l}\text { Number of } \\
\text { samples for } \\
\text { statistical } \\
\text { comparison }\end{array}$ & $\begin{array}{c}\text { Minimum } \\
\text { groundwater } \\
\text { value used for } \\
\text { statistical } \\
\text { comparison }\end{array}$ & $\begin{array}{l}\text { Maximum } \\
\text { groundwater } \\
\text { value used for } \\
\text { statistical } \\
\text { comparison }\end{array}$ & $\begin{array}{c}\text { Median } \\
\text { groundwater } \\
\text { value used for } \\
\text { statistical } \\
\text { comparison' }\end{array}$ & $\begin{array}{l}\text { Colorado } \\
\text { standard }\end{array}$ & $\begin{array}{l}\text { Type of } \\
\text { regulatory } \\
\text { standard }\end{array}$ & $\begin{array}{c}\text { Percentage } \\
\text { of sample } \\
\text { values that were } \\
\text { higher than the } \\
\text { standard }\end{array}$ & $\begin{array}{c}90 \text { percent } \\
\text { prediction interval } \\
\text { (alpha }=0.10) \\
\text { for the data }{ }^{2}\end{array}$ & $\begin{array}{c}p \text {-value } \\
\text { for sign } \\
\text { test }^{3}\end{array}$ & $\begin{array}{c}\text { Are concentrations } \\
\text { significantly } \\
\text { (alpha }=0.05 \text { ) } \\
\text { higher than the } \\
\text { regulatory standard? }\end{array}$ \\
\hline \multicolumn{11}{|c|}{ Silver } \\
\hline$\overline{\text { DTX1 }}$ & 23 & $<0.01$ & $<0.5$ & $<0.2$ & 50 & $\mathrm{H}$ & 0 & $0-<0.5$ & $>0.9$ & No \\
\hline DTX2 & 27 & $<0.01$ & $<0.5$ & $<0.3$ & 50 & $\mathrm{H}$ & 0 & $0-<0.5$ & $>0.9$ & No \\
\hline D6 & 27 & 0.04 & $<2.5$ & $<2.5$ & 50 & $\mathrm{H}$ & 0 & $0-<2.5$ & $>0.9$ & No \\
\hline D17 & 23 & $<0.01$ & $<0.2$ & $<0.1$ & 50 & $\mathrm{H}$ & 0 & $0-<0.2$ & $>0.9$ & No \\
\hline D25 & 27 & $<0.01$ & $<0.5$ & $<0.2$ & 50 & $\mathrm{H}$ & 0 & $0-<0.5$ & $>0.9$ & No \\
\hline \multicolumn{11}{|c|}{ Uranium } \\
\hline DTX1 & 23 & 33.4 & 54.4 & 38.9 & 30 & $\mathrm{H}$ & 100 & $33.5-50.6$ & 0.000 & Yes \\
\hline DTX2 & 27 & 26.0 & 35.4 & 30.6 & 30 & $\mathrm{H}$ & 56 & $26.9-33.6$ & 0.33 & No \\
\hline D6 & 27 & 158 & 227 & 174 & 30 & $\mathrm{H}$ & 100 & $158-200$ & 0.000 & Yes \\
\hline D17 & 23 & 3.6 & 4.5 & 4.0 & 30 & $\mathrm{H}$ & 0 & $3.60-4.27$ & $>0.9$ & No \\
\hline $\mathrm{D} 25$ & 27 & 25.8 & 41.3 & 30.2 & 30 & $\mathrm{H}$ & 56 & $26.2-40.7$ & 0.33 & No \\
\hline \multicolumn{11}{|c|}{ Zinc } \\
\hline$\overline{\text { DTX1 }}$ & 23 & 1.1 & $<28.0$ & $<28.0$ & 2,000 & $\mathrm{~A}$ & 0 & $0-<28$ & $>0.9$ & No \\
\hline DTX2 & 27 & 1.6 & $<22.4$ & $<22.4$ & 2,000 & A & 0 & $0-<22.4$ & $>0.9$ & No \\
\hline D6 & 27 & 2.9 & $<56.0$ & $<56.0$ & 2,000 & A & 0 & $0-<56$ & $>0.9$ & No \\
\hline D17 & 23 & 0.3 & $<2.8$ & $<1.8$ & 2,000 & A & 0 & $0-<2.8$ & $>0.9$ & No \\
\hline D25 & 27 & 1.2 & $<28.0$ & $<28.0$ & 2,000 & A & 0 & $0-<28$ & $>0.9$ & No \\
\hline
\end{tabular}

${ }^{1}$ Many of the values used in the statistical comparison were derived from concentrations that were less than the minimum reporting level, which varied, and therefore were set equal to the highest minimum reporting level.

${ }^{2}$ The 90-percent prediction interval for the data was calculated for nonparametric distributions (Helsel and Hirsch, 2002, p. 77-78).

${ }^{3}$ The $p$-value results from a one-tailed Sign Test (Helsel and Hirsch, 2002), which is used to indicate the level of statistical evidence that selected constituent concentrations are significantly greater than the regulatory standards. A value close to 1.0 indicates less evidence that the median concentration exceeded the standard, whereas a value close to 0 indicates much evidence that the median concentration exceeded the standard. The percent confidence of the test can be determined by subtracting the $p$-value from 1 and multiplying by 100 .

${ }^{4}$ Data compared to standard are for nitrite plus nitrate as nitrogen. U.S. Geological Survey data indicate nitrite is a minor component. 
Appendix 11. Statistical evaluation of time-series trend using the Kendall's tau correlation coefficient for selected dissolved constituents in groundwater samples collected near Deer Trail, Colorado, 2004-2010.

[Kendall's tau statistic (Helsel and Hirsch, 2002) is used as an indicator of monotonic correlation between concentration and time. Kendall's tau is a number between -1 and +1 where values closer to zero indicate lesser strength of the correlation. Estimated and variably censored data were recensored to the highest minimum reporting level for this evaluation. Where significant trends were indicated by this test, the concentration data were checked for serial correlation using a Wilcoxan Rank Sum test; no data were found to have serial correlation (alpha $=0.05$ ). Only the five wells listed below had enough samples analyzed to have trend analysis. N, number of samples; <, less than; NA, not applicable because all data were tied so the test statistic was zero]

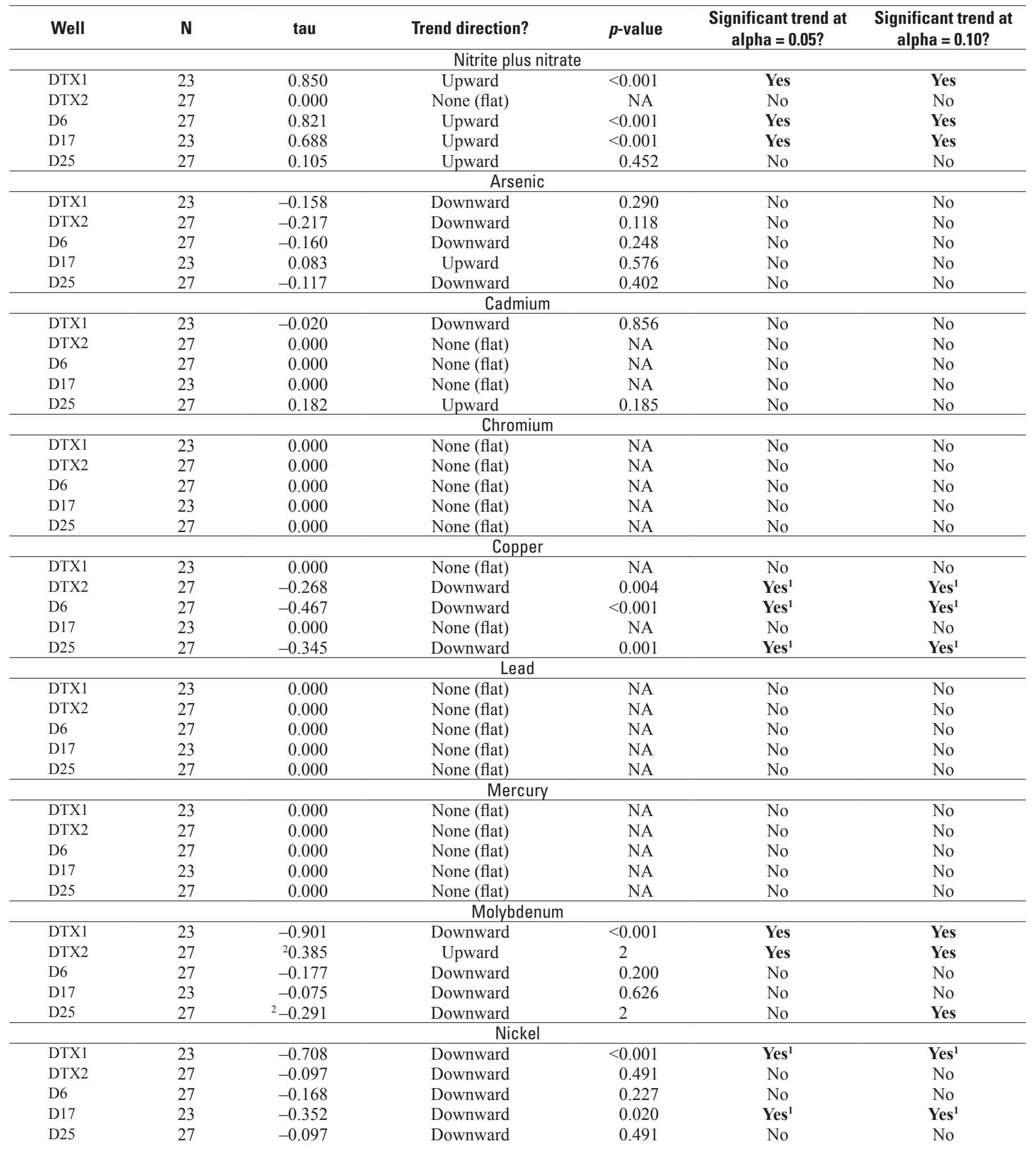


Appendix 11. Statistical evaluation of time-series trend using the Kendall's tau correlation coefficient for selected dissolved constituents in groundwater samples collected near Deer Trail, Colorado, 2004-2010._- Continued

[Kendall's tau statistic (Helsel and Hirsch, 2002) is used as an indicator of monotonic correlation between concentration and time. Kendall's tau is a number between -1 and +1 where values closer to zero indicate lesser strength of the correlation. Estimated and variably censored data were recensored to the highest minimum reporting level for this evaluation. Where significant trends were indicated by this test, the concentration data were checked for serial correlation using a Wilcoxan Rank Sum test; no data were found to have serial correlation (alpha $=0.05$ ). Only the five wells listed below had enough samples analyzed to have trend analysis. N, number of samples; <, less than; NA, not applicable because all data were tied so the test statistic was zero]

\begin{tabular}{|c|c|c|c|c|c|c|}
\hline Well & $\mathbf{N}$ & tau & Trend direction? & $p$-value & $\begin{array}{c}\text { Significant trend at } \\
\text { alpha }=0.05 ?\end{array}$ & $\begin{array}{c}\text { Significant trend at } \\
\text { alpha }=0.10 ?\end{array}$ \\
\hline DTX1 & 23 & 0.186 & Upward & 0.224 & No & No \\
\hline D6 & 27 & 0.536 & Upward & $<0.001$ & Yes & Yes \\
\hline D17 & 23 & 0.589 & Upward & $<0.001$ & Yes & Yes \\
\hline D25 & 27 & -0.234 & Downward & 0.091 & No & No \\
\hline DTX2 & 27 & 0.000 & None (flat) & NA & No & No \\
\hline D6 & 27 & 0.000 & None (flat) & NA & No & No \\
\hline D17 & 23 & 0.000 & None (flat) & NA & No & No \\
\hline D25 & 27 & 0.000 & None (flat) & NA & No & No \\
\hline \multicolumn{7}{|c|}{ Tungsten } \\
\hline DTX1 & 23 & 0.000 & None (flat) & NA & No & No \\
\hline \multicolumn{7}{|c|}{ Uranium } \\
\hline DTX1 & 23 & 0.478 & Upward & 0.002 & Yes & Yes \\
\hline DTX2 & 27 & -0.311 & Downward & 0.024 & Yes & Yes \\
\hline D6 & 27 & 0.208 & Upward & 0.132 & No & No \\
\hline D17 & 23 & -0.047 & Downward & 0.771 & No & No \\
\hline D25 & 27 & 0.023 & Upward & 0.884 & No & No \\
\hline \multicolumn{7}{|c|}{ Zinc } \\
\hline DTX1 & 23 & 0.000 & None (flat) & NA & No & No \\
\hline DTX2 & 27 & 0.000 & None (flat) & NA & No & No \\
\hline D6 & 27 & 0.000 & None (flat) & NA & No & No \\
\hline D17 & 23 & 0.000 & None (flat) & NA & No & No \\
\hline D25 & 27 & 0.000 & None (flat) & NA & No & No \\
\hline
\end{tabular}

${ }^{1}$ An apparent trend is caused by a block of slightly higher values at the beginning of the data set followed by lower values and censored values with lower minimum reporting levels. Trend likely is the result of increased laboratory precision and sensitivity, not changes in groundwater quality.

${ }^{2}$ Test statistic and significance confirmed by manual calculation using correction for ties. 
Publishing support provided by:

Denver Publishing Service Center

For more information concerning this publication, contact:

Director, USGS Colorado Water Science Center

Box 25046, Mail Stop 415

Denver, CO 80225

(303) 236-4882

Or visit the Colorado Water Science Center Web site at: http://co.water.usgs.gov/ 
